\title{
SOCIAL WELFARE IN MUSLIM SOCIETIES IN AFRICA
}

\author{
Edited by \\ Holger Weiss
}


Indexing terms

Economics

Education

Islamic countries

Religion

Social welfare

Sufism

Zakāt

Ghana

Morocco

Nigeria

Senegal

Sudan

Cover photo: Holger Weiss

Language checking: Elaine Almén

(C) The authors and Nordiska Afrikainstitutet, 2002

ISBN 91-7106-481-8

Printed in Sweden by Elanders Gotab, Stockholm 2002 


\section{Contents}

Preface 5

CHAPTER I

Holger Weiss

Zakāt and the Question of Social Welfare: An Introductory Essay

on Islamic Economics and Its Implications for Social Welfare

CHAPTER II

Endre Stiansen

Is there Room for Non-Muslims in the Sudan's Islamic Economy?

CHAPTER III

Franz Kogelmann

Sidi Fredj: A Case Study of a Religious Endowment

in Morocco under the French Protectorate

66

CHAPTER IV

Knut S. Vikør

Sufism and Social Welfare in the Sahara

CHAPTER V

Rüdiger Seesemann

Sufi Leaders and Social Welfare:

Two Examples from Contemporary Sudan

CHAPTER VI

Roman Loimeier

Je veux étudier sans mendier:

The Campaign Against the Qurāanic Schools in Senegal

CHAPTER VII

Sulemana Mumuni

A Survey of Islamic Non-Governmental Organisations in Accra

CHAPTER VIII

Holger Weiss

The Concept of Islamic Economy as Articulated in Sokoto:

Social Justice and State Responsibility 160

Contributors 



\section{Preface}

In recent decades there has been an increasing attempt by Muslim intellectuals to reflect about the provision of social welfare in Muslim societies in Africa. One reason of this are the few, if not non-existent possibilities of the states to provide for basic needs for their subjects, a situation that has become painfully evident in most African states. Another reason for the upsurge of Muslim activities is due to the rise of Islamism and the critique of the secular state, not only in Africa but throughout the Muslim world. One of the key elements in this debate has been the development of Islamic economics.

However, public as well as private provision of social welfare is not a new phenomenon in the Muslim world. Whereas government and public involvement in the provision of social welfare has been haphazard, despite various attempts at direct state involvement especially in the post-colonial world, private and what might be labelled as semi-official activities, such as the establishment of pious foundations and the activities of the Sufi orders, have a solid foundation in local Muslim societies.

This collection attempts to emphasise the variety of both agents and ways to provide social welfare in Muslim societies in Africa. In addition, social welfare, as such, is both being reflected upon and debated by Muslim intellectuals. Our attempt has therefore been to capture both the theoretical as well as the actual dimension of social welfare.

Most of the papers in this collection were first presented at a workshop on "Social Justice, Social Welfare and Praxis in Islamic Societies in Africa", organised in Helsinki during April 1999. ${ }^{1}$ Weiss's introductory essay in Chapter I and Mumuni's overview in Chapter VII are not from the workshop. In his introductory essay, Weiss presents a general introduction to zakāt as being one of the projected cornerstones of an Islamic social welfare system. Islamic economics is further discussed by Stiansen in Chapter II. Stiansen's focus is on the situation in Sudan, especially focussing on the question of Islamic banking. Another aspect of Islamic social welfare is taken up by Kogelmann in Chapter III, namely that of religious endowments. Kogelmann's case-study deals with colonial Morocco and provides a discussion of an institutionalised form of social welfare. The role of Sufi orders is discussed by Vikør (Chapter IV), Seesemann (Chapter V) and Loimeier (Chapter VI). Vikør's focus is on the Sanūsiya and their activities in the Sahara during the nineteenth century, whereas Seesemann presents the activities of two Tijānī Sufi shaikhs in contemporary Sudan. Loimeier's presentation, on

1 The workshop was orgnised by the Department of Asian and African Studies, University of Helsinki and the University of Helsinki research project "Zakāt: Poverty, social welfare and Islamic taxation". Additional funding for the workshop was received from the Academy of Finland. 
the other hand, concerns the 1992 campaign by the Senegalese government, UNICEF and a number of Islamic reform movements against Qur'ānic schools operated by Sufi shaikhs in Senegal. In Chapter VII, Mumuni provides an overview of Muslim NGOs in Ghana, especially those active in Accra. In the last chapter, Weiss gives a presentation of some Nigerian contributions in Islamic economics and discusses their possible implications. 


\title{
CHAPTER I \\ Zakāt and the Question of Social Welfare
}

\author{
An Introductory Essay on Islamic Economics \\ and Its Implications for Social Welfare
}

Holger Weiss

This introductory essay presents a discussion about a particular discourse within Islamic studies, namely the attempt to create a social welfare system through the establishment of an Islamic economy. However, instead of focussing on the subject of Islamic economics merely from within, there will be an attempt to locate the discussion within the framework of a larger developmental discourse. Therefore, while the first part of the essay will concentrate on Islamic economics and the creation of a social welfare system, the second part of the essay will focus on the recent establishment of various zakāt organisations and put the discussion within an African context. ${ }^{1}$

Twentieth century Muslim social scientists and economists have underlined that there is a possibility of an Islamic welfare concept based upon zakāt. ${ }^{2}$ Critical Muslim economists have claimed that the only way forward for today's Muslim societies is a return to the Islamic values and bases of the legal, social and political system. ${ }^{3}$ Such an approach has been criticised by Western scholars as overlooking the built-in discrepancy between ideals and reality in Islamic social theory. Therefore, Western research has regarded such studies as apologetic. ${ }^{4}$

A key problem with zakāt as providing the basis of an Islamic welfare system is the role of the state. According to the advocates of Islamic economics, an Islamic state would and should introduce an Islamic social welfare system. However, at the moment, there exists no Islamic state-at least not in the sense of the apologetics of Islamic economics. There are several regimes and governments in the present Muslim world, such as Iran, Libya, Pakistan, Malaysia or Sudan, that claim to have established or are about to introduce an Islamic order, but none of these states would fulfil the requirements of having established an Islamic economy-not to speak of an Islamic social welfare system. In some Muslim states, Islamic banking has been introduced and

\footnotetext{
1 The latter part of the essay is to some extent a follow up of my discussion on the emergence of Islamic economics in Northern Nigeria in Chapter VIII.

2 See Ahmad 1991.

3 Siddiqi 1948; Qutb 1953. See also Wilson 1998.

${ }^{4}$ Ule 1971; Reissner 1991.
} 
Islamic banks have been established, ${ }^{5}$ whereas other sectors of Islamic economics remain undeveloped or have not been implemented at all, such as state or public supervision of the collection and distribution of zakāt.

In this study, the question of zakāt will be discussed from a theoretical perspective. What is the role of the state in respect to zakat? Whereas it can be argued that zakāt belonged to the public sphere during the early days of Islam, this has become a confusing situation during later periods. As long as the community was of a limited size, the Prophet was able to control the collection and distribution of the alms. Under the first caliph, Abu Bakr, the role of the state was further strengthened: refusal to pay zakāt led to the ridda wars. However, after the expansion outside of the Arabian peninsula, the role of the state seems to have been changed: zakāt was certainly still collected, but it was organised on a local level by the local imam. With the breakdown of caliphate rule and the division of the community into several regional political entities, it seems as if the role of the state as the supervisor of the collection and distribution was lost. What remained was the ideal setting: the Islamic state enforcing Islamic law and, as a consequence, the collection and distribution of the Qur’ānic taxes.

Reality, however, proved to be different from the ideal. To meet the expenditures, most Muslim states started to collect extra-Qurāanic taxes. This rift between the ideal and the reality was to be articulated by the critics of the rulers and their regimes; the key argument being that the rulers were not ruling according to Islamic law and had neglected their duties towards the community of believers. Critics usually pointed at the heavy taxation imposed upon the commoners, arguing that within the "Islamic state" Muslims only had to pay the Qur'ānic taxes. The similarity of the development from a scholarly critique of the state of affairs to an open rebellion against the ruler in many Muslim regions is striking. One common argument has usually been the denouncement of the rulers and the state as being non-Muslim and the attempts to establish conditions resembling those of the community of the Prophet in Medina: the ideal state realised on earth. ${ }^{6}$

However, as will be discussed in the second part of the study, is the state the most feasible unit for the establishment of an Islamic social welfare system that would be based on the collection and distribution of zakāt? Starting from a questionnaire on zakat that was sent to a hundred ${ }^{\mathrm{c}} u l a m \bar{a}^{\mathrm{P}}$ in Pakistan by Shaikh Mahmud Ahamd in the late 1970s, the question of zakät will be put into a discussion of the establishment of an Islamic order, not an Islamic state. A tentative hypothesis will be brought forward about the possibility of an Islamic social welfare system within a modern, post-colonial and usually secular state without the need for the establishment of an Islamic state.

5 This subject is discussed in Endre Stiansen's article on the Sudan's Islamic Economy, see Chapter II.

${ }^{6}$ For a modern discussion and synthesis of the ideals and rules of $z a k \bar{a} t$, see al-Qardawi 1999. 


\section{The Ideal of the Islamic State}

A general trend within the political writing of Muslim scholars has been the argument of the corruptness of the time they were living in. Muslim regimes and rulers past and present are usually depicted as morally corrupt, the state being corrupt and the political arena having become a playing field for individualists who only care about their own interests. ${ }^{7}$ The poor economic and political performance of the post-colonial Muslim states has led to a rising critique by Muslim scholars among whom the concepts of the Islamic state, Islamic economics and zakāt take a central position in their argumentation. The general logic of the scholars is that the present secular economic system in the Islamic world should be replaced by an Islamic economic system. The central feature of the proposed system is that individuals are guided in their economic decisions by a set of behavioural norms, which are derived from the Qur’ann and the Sunna. In addition to the Islamic norms the Islamic system is to include zakāt, which is to be the basis of an Islamic fiscal policy, and the prohibition of interest, which is to be the basis of an Islamic monetary policy.

As such, the modern concept of the Islamic state is a new one, being the outcome of scholarly debate during the twentieth century. The concept of an Islamic state was constructed as an alternative to the failure of the various secular nation-states in the Middle East during the twentieth century. ${ }^{8}$ It became the cornerstone of the argumentation of the various Islamist and other critical scholars, who rejected both the Western Capitalist and the Socialist models. For example, Asad pointed out that:

... a state inhabited predominantly or even entirely by Muslims is not necessarily synonymous with an 'Islamic state': it can become truly Islamic only by virtue of a conscious application of the sociopolitical tenets of Islam to the life of the nation, and by an incorporation of those tenets of Islam to the life of the nation, and by an incorporation of those tenets in the basic constitution of the country. ${ }^{9}$

Thus, Asad and others have been able to label both the existing Muslim (nation) states as well as all the previous states within the Islamic world as not being true 'Islamic states':

There has never existed a truly Islamic state after the time of the Prophet and the Medina Caliphate ... (because) they fully reflected the pristine teachings of both the

\footnotetext{
7 Such arguments can be found in works by, among others, past scholars such as al-Māwardī, Ibn Taimìya and Ibn Khaldūn, but also among Muslim scholars and academics of the twentieth century, such as Muḥammad Bāqir al-Ṣadr, Sayyid Qutb, M.A. Mannan or S.A. Siddiqi, to mention a few.

8 See also my discussion in Chapter VIII.

9 Asad 1985, 1.
} 
Qur'ān and the Prophet's Sunnah, and were yet unburdened by latter-day theological accretions and speculations. ${ }^{10}$

One key argument among the 'Islamic-system school' is that the precondition for the implementation of an Islamic system is the creation of an Islamic state. Within the Islamic state, an Islamic economic system is to be created. It would be the responsibility of the Islamic state to care for the social welfare of all people $^{11}$ whereas the primary role of the Islamic norms is to make the individual member of Islamic society, homo islamicus, socially responsible and altruistic. Furthermore, the 'Islamic-system school' claims as a proof of the validity of an Islamic system that the historical record of Islam amply demonstrates that it is possible to create a society whose members adhere to the Islamic norms and which embodies a benevolent state. According to M.A. Mannan,
It is a verdict of history that the Abbasid period saw the culmination of several taxes introduced during the time of the prophet. The peace and economic prosperity that prevailed during the period of Islamic history is indicative of the fact that the financial system was quite sound and practical. The very fact that the tax structure of early Islam was elastic and dynamic is a great lesson for the modern economic experts and financial wizards. 12

The prototype of the Islamic state was the "Islamic system during the classical period", according to S.A. Siddiqi, one of the founding fathers of the discipline of Islamic economics and a key figure in the Islamic system school. The classical era, namely the period of the Prophet and the rule of the four 'rightlyguided' caliphs, i.e., a period much shorter than the one proposed by Mannan above, is said to have been a society in which there was no accumulation of wealth in a few hands, no hoarding and no profiteering - in other words the perfect Islamic system. The state was said to have been responsible for the social welfare of each member of the society, i.e., the just Islamic state materialised on earth: "We are not talking of an Utopia or of an ideal state. It was a real society which blossomed and died out and has gone into the limbo of the Past."13

According to Siddiqi, zakāt would be the cornerstone of the financial structure in an Islamic state:

$$
\begin{aligned}
& \text {... zakāt is a compulsory tax levied by an Islamic state or the members of the Muslim } \\
& \text { community, so as to take the surplus money from the comparatively well-to-do mem- } \\
& \text { bers of the society and to give it to the destitute and needy. } 14
\end{aligned}
$$

Thus, it is the objective of the Islamic state to care for the welfare of its weaker members-a point usually emphasised by the Islamic economists. However,

\footnotetext{
10 Asad 1985, V-VI.

11 cAzìz 1992, 140, 151.

12 Mannan 1970, 283.

13 Siddiqi 1948, vi.

14 Siddiqi 1948, 9.
} 
this argument must be understood as being both a political statement as well as an outline of an ideological charter. The critique is directed against the contemporary state of affairs; the charter is rather wishful thinking based on an uncritical reading of the early period of Islam. I therefore agree with Kuran's (1986) critical remarks about the idealistic picture that the modern adherents of Islamic economics present about the existence of a harmonious and perfectly just society during the times of the Prophet and his four successors. However, as an ideal, the concept of the Islamic state and the example of the Prophet and his companions have been and will be used by both propagandists and reformers to legitimise their critique of the state of affairs.

\section{The Ideal State and the Reality}

The question of how to rule the community of the believers, the umma, and who should and could have the authority to rule, has been the main cause for dissent and friction since the murder of the third caliph, Uthman, and has overshadowed the history of Islam since then. ${ }^{15}$ There are also strong similarities between the doctrines of the orthodox $f u q a h \vec{a}$, scholars of religious law or Muslim literati, of the classical era up to the thirteenth and fourteenth centuries $\mathrm{AD}$ and twentieth century writers. ${ }^{16}$ Both use a dichotomy of the present as a period of decadence and the past as a golden age. For both, the ideal was the constitution of Medina and the rule of the Prophet Muhammad. Thus, the articulation of present-day Islamist writers of the ideal of an Islamic state is used as an analytical tool to study past events as well as providing the means to interpret the present. ${ }^{17}$

The rift between the ideals of the Muslim scholars and the political reality had become quite obvious by the fourteenth century, when Ibn Khaldūn wrote his Muqqadima. Compared to the earlier jurists, who tried to place the

15 Zubaida, for example, notes that demands for the institution of a legitimate state as against an allegedly ungodly one have always been made historically in the name of an alternative prince, usually designated in terms of lineage, notably the Alid, or of a messianic Mahdi (Zubaida 1993, 155). However, for West Africa as well as other peripheral regions of the Islamic world, one would also have to include the key role of the Muslim literati and Sufi shaikhs.

16 For example, Ibn Taimiya has perceived a kind of renaissance among some critical Muslim scholars during the twentieth century. According to Islahi (1988, 253), "Ibn Taimiyah's thoughts on the role of the state are highly relevant and valuable. He discusses the need for a state and its duties towards the economic well-being of the people".

17 The ideal Islamic state was the Islamic community founded by Muhammad in Medina. Within that community, the state was but the plurality of its citizens unified by faith and obedience to the commands of God. The army was but the citizenry in arms, and institutions such as the shüra, the council, and the $b a y^{c} a$, the collective oath of allegiance, were meant to ensure representative and responsible government (Zubaida 1993, 44-45). The ideal Islamic state, however, is as much of a mythification as that of the ideal community, the umma. This period, known as the golden or true Islamic era, was one when the state and community were regarded as the same, when religious and political rule were unified in one person and when the rulers ruled according to the Qur'ān and the sunna-or according to their spirit, since the Qurān and the sunna had yet to be codified. 
state within the legal-religious sphere, Ibn Khaldūn clearly recognised the distinction between mulk, kingship or secular authority, and the caliphate. According to Ibn Khaldūn, mulk-rule should be based upon the use of political-military power and coercion whereas the ${ }^{\mathrm{c}} u \operatorname{lam} \bar{a}^{\mathrm{J}}$ were to assume a subsidiary position within government. The rule of the caliphate was to be based upon the application of religion and $\operatorname{sharì}^{c} a$. However, Ibn Khaldūn's distinction between kingship and caliphate was more than a ex post facto description because it resulted in an analysis of the cyclical behaviour of the rise and fall of states by emphasising that the caliphate-rule had been replaced by mulk-rule as part of a specific political cycle. As had become painfully evident for the Muslims one century after the death of the Prophet, neither the caliphate nor the umma had remained unified or even came close to the religious-political intentions and revelations of the Prophet. On both political and religious grounds, the umma was split among different sects. The reality, which Ibn Khaldūn had described as mulk-rule, had little in common with the political-religious ideals which were pointed to by the Muslim literati and jurists, the ${ }^{\mathrm{c}} u \operatorname{lam}_{\bar{a}}$,ortheadvocatesofpopularIslam,suchassufismwithin Sunni Islam. ${ }^{18}$

What existed, and still exists, were Muslim not Islamic states, as the Islamic state per definition is a state "that pertains to Islam as a religion, an ideology, and a system of life" ${ }^{19}$ The problem of any Muslim state was how to secure enough income to cover its expenses. As long as there were enough subjects that paid jizya, there was enough revenue available, but when income from jizya declined, the state was facing a fiscal crisis. The fiscal crisis became aggravated if its expansion was halted and the income from khums, the fifth of revenues from military expeditions, disappeared. In such a situation, zakāt became a problem because the state could not use the income from it to cover its expenses. Further, to broaden the fiscal basis was impossible, at least in theory, due to the demand that only Qur ānic taxes could be levied. However, the fiscal crisis usually led to a break with the Qur'ānic basis of taxation and the introduction of extra- and non-Qurānic levies $(m u k \bar{u} s)$. Such a policy did, however, as a rule lead to fierce criticism from the $u$ lam $\bar{a}$, especially from those scholars who opposed the acts of the rulers and who demanded the abolition of such levies. It was therefore problematic for the Muslim state to push for a reorganisation of the tax basis. As long as Qur'annic taxes were levied, the main pressure was put on the rural population, but any attempt to relocate the tax burden and shift it towards the urban population, trade and crafts, was ideologically, if not politically, more or less impossible. ${ }^{20}$ Therefore, the Muslim ruler was caught in a dilemma-to increase taxes and face the possibility of a revolt or to stick to the ideal and face a financial crisis. This dilemma provided Ibn Khaldūn with his theory of the rise and fall of states as

\footnotetext{
18 Ibn Khaldūn 1989, 200-06.

19 Al-Buraey 1985, 25.

${ }^{20}$ Feldbauer 1995, 279-81.
} 
well as Ernst Gellner (following Ibn Khaldūn) with his notion of the 'permanent Islamic revolution':

\begin{abstract}
But what would happen ... if some authoritative cleric, having with some show of plausibility denounced the impiety and immorality of the ruler, thereby also provided a banner, a focus, a measure of unitary leadership for the wolves? What if he went into the wilderness to ponder the corruption of the time, and there encountered, not only God, but also some armed tribesmen, who responded to his message? This ever-latent possibility hangs over the political order, and is perhaps the Islamic form of permanent revolution. 21
\end{abstract}

The rift between the real world and the speculations about a perfect economic system within an ideal politico-cum-religious environment has had a great variety of consequences in the Islamic world. First, the rift might be interpreted in a negative way: the impossibility of establishing utopia on earth. Such an interpretation might result in a fatalistic worldview. However, as has become evident in the previous outline, Muslim intellectuals cannot, as such, be regarded as propagators of a lost cause, doomed to the darkness of fatalism. Instead, one key argument has been the need for change, usually the call for a revival of the 'perfect community' which existed during the early days of Islam. Thus, the rift between the real and the ideal world demands of the true believers an effort "fī sabīl Allāh" - for the cause of Allah. It is a future-oriented projection - the establishment of an Islamic state-although it rests on the re-enactment of a 'true but lost reality'. Therefore Gellner's notion of a 'permanent revolution' is one of the driving forces within the Islamic world: people's failure to establish utopia on earth due to their imperfections is not the end of history but in fact the impetus of it. As, according to Islam, no one can be above the Law, because it is God's Law and the caliph is only His vice regent here on earth, himself being only a primus inter pares, God's Law must be the guiding line of society as a whole, be it in politics, economics, trade or social life. Back to utopia? Not necessarily, because the demand of the rule of God's Law on earth does give the custodians and interpreters of the Law a central position.

One consequence of the 'permanent revolution' is that the question of obligatory almsgiving and, most important, the question of permitted and forbidden taxes is almost always raised by those Muslim scholars who are critical about the political regime. Any ruler who, deliberately or not, is sidestepping the Qur ânic taxes or introduces extraordinary taxes and levies is faced with the charge of the scholars that he is breaking with the rules of Islam. Some scholars might even argue that the time has come to topple the regime and replace it with a new one that would rule according to Islamic Law and ethics. If successful in their aspirations, an Islamic state might be established by the critical scholars. However, the problem with the scholar who becomes the leader of a religious-cum-political movement is that almost immediately as he becomes the new ruler, he is no longer the erector of a perfect society but

21 Gellner 1981, 45. 
the administrator of a society where people are fallible. The moment he starts to rule as a political authority and makes his first compromise, utopia is lost again and the perfect Islamic state starts to fade away. After too many changes, compromises and the introduction of additional taxes to meet the growing demands of the court and the army, the Islamic state becomes just a mere façade, or, following Ibn Khaldūn, one is dealing again with Muslim states, ruled by 'secular' Muslim rulers who have no religious impact or position; Islamic law is enforced and might even be the guideline in society, but would not confine the ruler as $\mathrm{s} /$ he would rule with or without it.

\title{
Islamic Economics within the Ideal State
}

As mentioned above, there is a general agreement among late twentieth century Muslim economists that the precondition for an Islamic economy is the existence of the ideal Islamic state, based upon the model of the Medina Caliphate or the era of the combination between state and community. According to Karen Pfeifer:

\begin{abstract}
Islamic economics is a set of ideas evolving in the last decades of the twentieth century to explain and address the economic problems faced by the citizens of predominantly Muslim countries. ... It aims to recapture the original moral and political authority of the anti-colonial movements that gave rise to state capitalism, but without the latter's domineering centralism and bureaucratic rigidities. It aims to provide scope for individual economic initiative and markets, just as proponents of economic liberalisation do, but without the callous disregard for the evils of markets associated with unfettered capitalist systems in the West, such as extreme poverty and wealth. ${ }^{22}$
\end{abstract}

The upsurge of Islamic economics is reflected in the rise of Islamism throughout the Muslim world. According to Elizabeth Hodgkin, one must, however, distinguish between two different kinds of movements, one that she defines as Islamic resurgence and one called "Islamism". Whereas the former movement strives for an increase in religious observance and fervour but recognises different Islamic identities, the goal of the latter one is to bring Islam into every aspect of human life, political, social, economic and cultural. As such, "Islamism" is rather similar to earlier reform or revivalist movements in Islamic history in its demands for the purification of Islam and rejection of non-Islamic innovations. The key demands of today's "Islamists" is, however, the perception of Islam as a total religion. As a total religion, which does not accept any division between religious and secular life, such a condition can only be achieved by a purification of the state, namely by creating an Islamic order through the institution of Islamic Law as State Law and in the end by creating an Islamic state. However, as Hodgkin emphasises, the latter demand, namely that of the establishment of an Islamic state, does

22 Pfeifer 1997, 155. 
not have to be a uniform demand, as many Islamic movements do not see the seizure of state power as among their aims. ${ }^{23}$

One central position of Islamism is the rejection of the 'corruption and secularism' of the modern world. However, this opposition is not a rejection of modernity as such but, as both Western academics and Islamic economists have argued, a movement for the 'Islamisation of capitalism':

Where capitalism has failed it is seen as a corrupt Westernised capitalism which has only profited a small elite. By contrast, the organised Islamic state would bring social justice to all. 24

It is the demand of 'social justice for all' which, according to the propagators of Islamism as well as Islamic economics, would materialise through an Islamic welfare system, a system, which only an Islamic state would be able to establish. The emphasis is on the whole of society and not on individuals: the collective welfare of the umma is guaranteed through social and distributive justice, which in turn is manifested through the collection and distribution of zakāt. 25

In general, according to the ideas of Islamic economics, the state is to have an active role in the economy. Although there is no agreement among present-day Muslim economists on whether state intervention in the economy should be limited or not, there is a fundamental understanding among all of the writers about the responsibility of the state for the social welfare of all people. The emphasis on state responsibility within the social welfare sphere is not surprising, and gives an opening to address pre-twentieth century attempts to create the ideal state as well as the Islamisation of the economy.

Islamic economics is a rejection of both pure laissez-faire capitalism and socialism. According to Naqvi, the modern western welfare state doctrine would be, if it were based on Islamic principles, the equivalent of an Islamic economy. ${ }^{26}$ Pfeifer identifies three main principles of Islamic economics. First, Islamic economics locates the individual in an Islamic context. However, this homo islamicus is, in contrast to the Western homo economicus, under the moral supervision of the umma. The aims of this 'individual' are both directed towards the maximisation of individual material utility as well as serving the others and the Muslim community. The second principle concerns the prohibition on the payment or taking of interest on money loaned together with the prohibitions against speculation and wasteful consumption. The third principle concerns the question of zakāt and that of Islamic inheritance laws. ${ }^{27}$

\footnotetext{
23 Hodgkin 1998, 198-99. See also al-Buraey 1985, 202-03.

24 Hodgkin 1998, 200.

25 Al-Buraey 1985, 154.

26 Naqvi 1994, 79-80.

27 Pfeifer 1997, 157-59.
} 
The aim here is not to present a thorough definition and overview of the twentieth century debate about what zakāt should and must be. ${ }^{28}$ However, it should be emphasised that my understanding of the idea of zakat and the twentieth century debate differs from that of Karen Pfeifer. Whereas she stresses the fact that zakat is interpreted by contemporary Islamic economists as a voluntary tax on wealth administered through the mosques, and only critical Islamic economists would substitute the mosque-controlled network for the ineffective government welfare institutions, ${ }^{29}$ my reading of the literature would suggest that a much stronger emphasis should be placed upon the compulsory state tax or public responsibility to pay it. The question of the role of state intervention in the economy is much debated among contemporary Islamic economists. ${ }^{30}$ Thus, Sadr defines zakāt as a voluntary wealth tax which Muslims pay in recognition of their social responsibilities and opts for a limited role of state intervention. ${ }^{31}$ Siddiqi, again, emphasises the primary role of state-administrated social justice where zakat would be compulsory, collected by the state, and the state would also take over its redistribution, ${ }^{32}$ whereas Chapra underlines that zakät can only be of temporary assistance and cannot be a substitute for a modern welfare system. Chapra also rejects the idea of strong and active state intervention. ${ }^{33}$ Mannan argues that "the purpose behind all taxes in an Islamic state is one and the same, that is, motivated by the welfare of the people, no matter whether they are Muslims or non-Muslims" and that "zakāt is the pivot and hub of the Islamic public finance. It covers moral, social and economic spheres." ${ }^{34}$

Naqvi, on the other hand, states that an Islamic economic system would insist, at a given point in time, on maximising 'total' welfare, and not just 'marginal' welfare. ${ }^{35}$ Thus, following Naqvi's argument of the bias of Islamic economics towards social justice, an elaborate social security system based upon zakāt must form an integral part of the policy package in an Islamic economy. ${ }^{36}$ However, a different standpoint is taken by Muhammad A. alBuraey, who claims that minimisation of the distributive gap is to be the major social goal of an Islamic state. According to al-Buraey, social justice is

28 See further my discussion in Chapter VIII.

29 Pfeifer 1997, 158

30 Wilson 1998, 49-53.

31 Al-Șadr 1982; 'Azīz 1992, 151.

32 Siddiqi 1948, 8-9.

33 Chapra 1992, 223-24, 270-75.

34 Mannan 1970, 273, 284. According to Mannan, zakāt is the community's share in produced wealth.

35 Naqvi 1981, 65. See also Naqvi 1994, 104-07. Naqvi's distinction between 'total' and 'marginal' welfare is based on his argument that an Islamic welfare system should give assistance to all members of the community, not only the needy. In fact, what he is describing is the distinction between a 'minimal' and 'maximal' welfare system. According to the 'minimal' welfare system, only basic needs would be covered, whereas a 'maximal' or 'total' welfare system should aim at changing socio-economic as well as socio-political structures.

36 Naqvi 1981, 103-04. 
demanded through the Islamic principle of equal human dignity and brotherhood as well as the Islamic principle of the undesirability of the concentration of wealth and income in the hands of a few, yet, on the other hand, individual and private ownership and possession are to be guaranteed, not condemned. Similarly to Naqvi, however, al-Buraey grants to the state the responsibility of protecting and implementing such an economic system. ${ }^{37}$ Since any establishment of social justice by the use of force or by hindering private enterprise is considered unlawful, one could argue that an Islamic economic system does not seem to strive for a total eradication of poverty-poverty as such is as much the target as it is in fact a crucial and much needed component of the whole system.

The twentieth century debate among Islamic economists about the basis of an Islamic welfare policy and the question of zakat has its pre-twentieth century counterparts. Contemporary Islamic economists usually emphasise their 'new' interpretation of Islamic law when they underline that a strict revival of the Medina Caliphate is not possible but has to be implemented with the tools and understanding of modern society. However, the debate of the Islamic economists is not new. Before the debate on the possibilities of an Islamic economy by the economists, the ideal Islamic state with its socialwelfare-for-the-umma-principle had been debated and proposed by various Muslim literati. Whereas today's approach towards Islamic economics confines itself within the margins of economics, the traditional debate was developed within Islamic jurisprudence. With its strong emphasis on social justice and public responsibility for social welfare, Islamic jurisprudence does present a model of a pre-modern Islamic social welfare policy. This policy was to be centred upon the collection and distribution of zakāt as legal alms as well as the establishment of a bayt al-māl or Public Treasury. Revenue collected by the bayt al-māl was regarded as wealth to be treated as Allah's wealth or the Muslims' wealth, and it implied that the revenue collected into the bayt al-māl was Allah's trust and the common property of all Muslims, the ruler being merely in the position of a trustee. ${ }^{38}$

According to the financial doctrines of the Muslim scholars, the revenue of an Islamic state was divided between religious and secular revenue. Religious revenue consisted of zakät and the tithe (ushr), whereas secular revenue consisted of the land tax (kharāj), the poll-tax on non-Muslim subjects (jizya), 'the fifth' of the spoils of war (khums), as well as the tax on non-Muslim traders and the estates of deceased persons. ${ }^{39}$ The distinction between religious and

37 Al-Buraey 1985, 185-86, 188. According to him as well as other Islamic economists, an Islamic economic system would recognise the sanctity of wealth and respect private ownership as long as it does not conflict with the public interest.

38 Doi 1984, 387-88. See further the sections on zakāt in Ruxton 1916 and the thesis of Aghnides 1916. For a modern synthesis, see al-Qardawi 1999.

39 An outline is presented in Doi 1984, 388-91. Doi, however, makes a distinction between ushr and $u s h \bar{u} r$, the former being zakāt on agricultural produce and paid by Muslims, the latter being revenue collected from the proceeds of trade and business carried out by all citizens of the Islamic state irrespective of their belief. Other jurists and commentators, such as Aghnides, do 
secular revenue was due to the different rules of state expenditure. Whereas religious revenue could only be spent according to the rules of the Qur ${ }^{2} \bar{a}$, namely following sura 9:60, the expenditure of secular revenue was not earmarked by the Qurān or Muslim law.

Further, a distinction was made between the classes of revenue which accrue to the Muslim community or the Islamic state as distinct from the Public Treasury or bayt al-māl. However, there is a disagreement between the various Muslim schools of law on what should constitute the Public Treasury. Fourfifths of the fay revenue, that is jizya and kharajj, goes to the Public Treasury, according to the Shāficī doctrine, whereas, according to the Hanafī and Mālikī doctrine, the entire fay goes to the Public Treasury. One-fifth of the fay, as well as one-fifth of the booty revenue, should be divided into three parts, namely the Prophet's share, the share of the Prophet's relatives and a trust fund for orphans, the indigent and wayfarers that would be part of the Public Treasury. Of this part, the Prophet's share would go to the Public Treasury, according to Mālikī and Shāficī doctrine, whereas it should be kept outside the Public treasury according to the Hanāfì doctrine. The cases of zakāt and ushr were even more complicated. According to the Mālikī doctrine, zakāt, which is levied on both apparent and non-apparent property, 40 should be paid to state officials and thus would be part of the Public Treasury. However, according to Shāfici ${ }^{-}$doctrine, zakāt on non-apparent property was under no circumstances part of the Public Treasury while zakāt on apparent property might only be held as a trust and, as such, was not a part of the Public Treasury. ${ }^{41}$

Despite the efforts of the various Islamic schools of law to establish a genuine theory of how to handle social and economic problems of Muslim society, the outcome has been more or less confusing. One fundamental problem has been that the aim of the Muslim scholars was not the non-divine/secular society of the real world but was directed at speculation about the possibilities and outlines of a divine order. The fiscal and economic realities in Muslim societies were hardly mentioned. However, the legal speculation and outlines of Islamic taxation, together with the claimed responsibilities of an Islamic state, were used by leaders of revivalist and reform movements in their critique of the state of affairs in Muslim societies and their call for an overthrow of 'unjust' rulers. The question of the just and legal collection of zakāt was especially used by the critics of unpopular Muslim rulers. Taxation was condemned as non-Islamic and a true Islamic state was painted as the counter-factual cause for the critique of an unjust ruler.

not make such a distinction. Interestingly, Doi argues that kharāj is not paid by Muslims but by non-Muslims and that it is the equivalent to $u s h r$, which is not paid by non-Muslims.

40 In general, apparent property consists of animals and crops whereas non-apparent property consists of personal wealth and articles of trade. However, the various Muslim schools of law disagree among themselves on this distinction (Aghnides 1916, 296-301).

41 Aghnides 1916, 423-28. 


\section{A Call for Re-Opening the Rules of Zakāt}

During the late 1970s, the Pakistani scholar Mahmud Ahmad sent out a questionnaire to about one hundred Muslim scholars and imams in Pakistan, asking them about the state of zakāt and the possibilities of implementing some changes in the collection of zakāt. ${ }^{42}$ The background of this questionnaire was the attempt by the Pakistani government of General Zia ul-Haq to establish an 'Islamic economy' in Pakistan. ${ }^{43}$ Apart from outlawing rib $\bar{a}$ (interest), zakāt was to be reinstated as an annual tax and would provide a social welfare fund. However, the attempt to build a social welfare system based on the collection of zakāt seemed to have caused concern among some scholars that the conventional rate of zakāt would be insufficient to meet the requirements of a modern social welfare system. Ahmad's agenda in his questionnaire was to ask the ${ }^{\mathrm{c}} u$ lam $\bar{a}^{\mathrm{j}}$ about the possibility of raising the rate of zakāt and extending the area of its impact:

If the conventional rate of zakat be incapable of meeting the eight objectives prescribed for it by the Holy Qur'an (ix. 60), what should be the goal of our socio-economic thinking: the eight objectives that are prescribed by the holy Book or the rate of zakat which is nowhere fixed by it? 44

Ahmad further asked whether or not it is the duty of an Islamic state to raise the rate and extend the impact of zakat. He pointed out that due to the absence of an organised collection of zakät and the neglect of the wealthy class in Pakistan to alleviate the situation of poor people in the country, social stratification and marginalisation have become a profound problem in Pakistan. He further criticised the argument by some scholars who forbid any changes in the rate of zakāt and instead argued for the introduction of additional taxes:

\footnotetext{
42 See "A Questionnaire on Zakat," in: Ahmad 1992.

43 The Pakistani government enforced the Zakah and Ushr Ordinance in 1980. Under this law, $z a k \bar{a} t$ is deducted from the assets of the citizens held in the form of deposits and accounts with the scheduled banks and financial institutions on the first of Ramadān each year. Zakāt is collected by the State Bank and deposited in the Federal Zakāt Fund, which disburses the amounts to the provincial zakāt departments. Of this money, some 40 per cent is then distributed to various institutions, such as schools and hospitals, whereas 60 per cent is channelled to one of the approximately 39,000 local zakāt committees. In the end, according to official claims, some 1.1 million households throughout the whole country are said to benefit by a monthly subsistence allowance of Rs 500. Although its distribution seems to be efficient and well organised, the system has been criticised for having some major drawbacks, not least that the amount of monthly subsistence allowance is too low and its disbursement and coverage too irregular as to make a great impact. Above all, there is a profound reluctance on the part of the general population to pay zakāt to the state. See further Farhan, Muhamad, "The collection of zakah in Pakistan", http: / / www.Islamiq.Com:/news/features/print.php4?news=1_26092000 (printed 6 May 2001).

44 Ahmad 1992, 77-78.
} 
If the anticipated income from zakat be not enough to meet even this target [i.e. the eradication of poverty, HW] and this has also to be supplemented by other taxes, do we not lose out of hand the entire significance of zakat? If zakat cannot even eradicate poverty, then what purpose zakat is supposed to serve? ${ }^{45}$

Ahmad's main argument was that there was a need to raise the rate of zakat, in fact, what he proposes is an extension and entire revision of the zakāt-rules. First, Ahmad argued that the rate of zakāt is not fixed. To strengthen his argument, he pointed out that the rules of zakāt were already revised by the second caliph, Umar, and proposed not only a correction of the rates but also an extension of the area of zakāt. Ahmad asked the ${ }^{\mathrm{c}} u$ lam $\bar{a} \mathrm{~s}$ whether or not it should be the task and duty of an Islamic state to meet the demands of social justice, to remove the privations of human beings, and to provide basic social welfare such as "... food, clothing, shelter, remuneration of physician, medicines, personal attendant to one incapable of helping himself and education" as well as it being the responsibility of the Islamic state to care for widows and orphans. ${ }^{46}$ Yet, although Ahmad did give an outline of an Islamic social welfare system, he was aware of its restrictions-funded through traditional zakāt it could not be realised:

Can unchangeable rate of zakat achieve this objective plan when 50 to $60 \%$ incometax has failed to achieve it?... Would you not agree that insistence on the unchangeable character of details of zakat has been the biggest obstacle in the way of the establishment of Islamic social order in this country?... Is it not time that we open the closed gate of Islam?... ${ }^{47}$

Although it seems unlikely that Ahmad's questionnaire and his demand for a redefinition of the rules of zakāt would have had a global impact, his attempt was, in a sense, a sign of an 'opening of the closed gate of Islam' regarding the collection and distribution of zakat. Since the 1980s, two discourses within the Muslim world are clearly identifiable, one where the role of the state and one where the role of non-governmental organisations is underlined. Muslim countries such as Pakistan, Malaysia, Kuwait, Saudi Arabia and the Sudan have tried to introduce Islamic economics and to establish an Islamic social welfare system, whereas, especially in non-Muslim countries, Muslim NGOs have taken over the role of the Islamic state. The collection and distribution of zakät is a cornerstone in both systems, it is through zakāt the system and its operations are financed. But whereas the collection and distribution of zakāt within the state system is handled by state appointed and supervised bodies and zakāt in fact resembles a mandatory obligation, even a religious tax, the activities of the Muslim NGOs are based on voluntary contributions.

\footnotetext{
45 Ahmad 1992, 79.

46 Ahmad 1992, 87-89.

47 Ahmad 1992, 93, 108, 111. Ahmad points to some problems if a traditional zakāt-rate were to be applied in Pakistan. For example, import duties on cars would be reduced from 100 per cent to 2.5 per cent, whereas imported cereals, on which there was no import duty, would also have to pay a 2.5 per cent import duty.
} 
However, in both cases Muslims are urged to pay zakāt. The argument that is stressed by both government as well as non-governmental organisations is that Muslims are obliged to pay zakāt. Further, it is argued that through the collection of $z a k \bar{a} t$, the provision of social welfare can be fulfilled.

\section{Regulating the Fifth Pillar in a Modern World-Fatāwin on Zakāt}

The modern-sunni-argumentation on zakāt is reflected in the legal opinions (fatāwin, sg. fatwā) produced by several special-purpose gatherings of Muslim scholars. In general, most of these fatäwin deal with the question of state or public supervision of the collection and distribution of zakat. It is underlined in the fatäwin that Islamic governments are obliged to establish a special organisation for collecting zakāt. Such organisations would be supervised by religious scholars and 'efficient employees', and are urged to have a separate balance sheet. In non-Islamic countries, there should be societies which direct their efforts to the collection and distribution of zakat. ${ }^{48}$ However, it is not allowed to deposit zakāt monies in 'usurious' banks. ${ }^{49}$ On the other hand, it is permissible to invest zakāt money in productive projects run by zakāt deserving recipients. Such projects would be supervised by the legal authority in charge of levying and distributing zakat. ${ }^{50}$ Moreover, it is stated that the lunar calendar should be taken into consideration when preparing the balance sheet. ${ }^{51}$

Another conclusion reached in the fatāwin is that taxes are to be levied by the state and that the payment of taxes does not replace the payment of zakatt. Following traditional zakāt-rules, it is underlined that zakāt is due on mature people as well as those under age, but in the latter case their guardians will give zakāt on behalf on them. However, the method of levying and distributing zakat should follow the conditions of each country [emphasis mine].52 Thus, national, if not local, conditions would regulate zakat. Does this mean that a universal praxis or guideline is considered non-existent-apart from the general rules of zakāt?

\footnotetext{
48 Fatwa delivered by the First Symposium of Zakah Contemporary Issues, Cairo 25 October 1988,6 . The obligatory nature of Zakah and the role of governments in Zakah collection and distribution, see http: / / zakat.Al-Islam.com/def/ (printed 25 January 2001).

49 Fatwa delivered by the Third Conference of the Islamic Bank held in Dubai, 23 September 1985, see http: / / zakat.Al-Islam.com./ def / (printed 25 January 2001).

50 Fatwa delivered by the Islamic Jurisprudence Academy of the Islamic Conference Organisation in Jeddah as well as Fatwa delivered by the Third Symposium on Zakah Contemporary Issues, Kuwait 2 December 1992, 'First: Investment of Zakah funds,' see http: / / zakat.Al-Islam.com/def / (both printed 25 January 2001).

51 Fatwa delivered by the First Zakah Conference, Kuwait 3 April 1984, '5. The lunar calendar,' see http: / / zakat.Al-Islam.com/ def / (printed 25 January 2001).

52 Fatwa delivered by the Second Conference of the Islamic Research Academy in Cairo, see http:/ / zakat.Al-Islam.com/def/ (printed 25 January 2001).
} 
According to the legal declarations, however, secular taxes should not be mixed with or replace zakāt. The balance sheet of the state should be financed by the revenues of the public possessions and other legal financial resources. If they are not sufficient, a government may fairly impose taxes in order to meet its expenditures and submit help to zakāt recipients if zakāt money is not sufficient. It is not allowed to use zakāt money for meeting their expenditures. Taxes do not replace zakāt because they were imposed by two different authorities and for extremely divergent targets. Besides, the amount and channels of both are entirely different. Therefore, taxes are not to be deducted from obligatory zakāt money. In addition, it is recommended that zakāt money should be deducted from taxes. ${ }^{53}$

Following both traditional argumentation as well as modern Islamic economics, zakāt is identified as providing the basis for achieving social solidarity in the Islamic countries. ${ }^{54}$ Zakat is identified as enabling the fulfilment of basic needs of the poor with regard to the provision of social welfare. 'Basic needs' are defined as necessities required for achieving sufficiency, such as food, accommodation and clothes, without extravagance or parsimony and social solidarity according to the prevalent customs [emphasis mine] ${ }^{55}$ In addition, zakāt money can be used in establishing service projects such as building schools, hospitals, orphanages and libraries. Such social projects would be run by the $z a k \bar{a} t$ recipients but managed by the government or its representatives. Free access for the use of social projects should only be provided to the zakat recipients. ${ }^{56}$

When discussing the distribution of zakāt, a rather traditional interpretation is applied, yet with less stress on the location. Although zakāt should be distributed to the recipients in the territory where it is levied, it is permissible to transfer zakāt to other territories as a means of achieving a legal target. ${ }^{57}$ Such targets could be, among others, Da'wa centres with the aim of spreading Islam as well as the establishment of mosques in non-Muslim countries or to use zakāt money to urge governments to improve the conditions of the Islamic minorities and support them in non-Muslim countries. ${ }^{58}$

53 Fatwa delivered by the Fourth Symposium on Zakah Contemporary Issues, Bahrain 29 March 1994, 'Third: Zakah and Taxes,' see http://zakat.Al-Islam.com/def/ (printed 25 January 2001).

54 Fatwa delivered by the Second Conference of the Islamic Research Academy in Cairo, see http: / / zakat.Al-Islam.com/ def/ (printed 25 January 2001).

55 Fatwa delivered by the First Symposium of Zakah Contemporary Issues, Cairo 25 October 1988, '8. Zakah and fulfilling the basic needs of the poor', see http:/ / zakat.Al-Islam.com/def/ (printed 21 January 2001).

56 Fatwa delivered by the Third Symposium on Zakah Contemporary Issues, Kuwait 2 December 1992, 'Second: The recipients' possession of Zakah money,' see http://zakat.AlIslam.com/def/ (printed 25 January 2001).

57 Fatwa delivered by the Second Symposium on Zakah Contemporary Issues, Kuwait 25 June 1989, see http: / / zakat.Al-Islam.com/def / (printed 25 January 2001).

58 Fatwa delivered by the First Symposium of Zakah Contemporary Issues, Cairo 25 October 1988, '7. The Zakah channel: "in the way of Allah",' see http://zakat.Al-Islam.com/def/ (printed 25 January 2001). See also the Decrees issued by the Islamic Jurisprudence Academy in 
A crucial case concerns whether an Islamic state could provide funds for international relief organisations. The matter was discussed by the jurists with regard to the Islamic Solidarity Fund (ISF). It was declared that it is not permissible to give zakat to the ISF. This fund was established by the ICO (Islamic Conference Organisation) to provide funds for social welfare projects in the Islamic world. The ISF was supposed to be financed by ICO member states and organisations. However, the Islamic Jurisprudence Academy in Jeddah declared in a fatwo $\bar{a}$ that the ISF could receive zakāt from individuals and organisations as well, provided that the ISF allocates a special account for zakāt money and that the receiver is granted the right to decide which of the eight categories is to be supported. ${ }^{59}$ Thus, the ISF was made equal with the state as the supervisor of zakāt, and by analogy, similar organisations could claim the same status.

However, with regards to national and non-governmental organisations, a different approach was chosen by the legal authorities. Modern zakāt organisations and committees are to be considered as a modern form of the old charity houses known in Islam. Such committees should be controlled and supervised by the authority which forms them. Employees in such organisations should meet the conditions required for whoever is employed to administer zakāt. The employees' remuneration and administrative expenses could be drawn from the Public Treasury, or, if this is not possible, from zakāt funds, though not more than one-eighth of the total zakāt money. ${ }^{60}$

\section{Independent Governmental Bodies}

The Kuwaiti Zakah House is one of those modern zakät organisations discussed in the fatāwin of Sunni scholars. It was established by the Kuwaiti government in 1982 and was charged with collecting and distributing zakāt in Kuwait as well as supporting groups outside Kuwait and charitable projects worldwide. ${ }^{61}$ All the above quoted fatāwin and symposiums of Muslim scholars were in fact organised by the Kuwaiti Zakah House. According to their wwwhomepage:

Mecca (Islamic World League), http://zakat.Al-Islam.com/def/ (printed 25 January 2001), Fourth Decree-Eighth Session, Levying and Distributing Zakah in Pakistan, as well as Fatwa delivered by the Third Symposium on Zakah Contemporary Issues, Kuwait 2 December 1992, 'Third: The channel of those whose hearts have been (recently) reconciled (to the truth),' see http:/ / zakat.Al-Islam.com/def/ (printed 25 January 2001).

59 Fatwa delivered by the Islamic Jurisprudence Academy of the Islamic Conference Organisation in Jeddah, see http: / / zakat.Al-Islam.com/def/ (printed 25 January 2001).

60 Fatwa delivered by the Fourth Symposium on Zakah Contemporary Issues, Bahrain 29 March 1994, 'First: The channel of those employed to administer Zakah,' see http: / / zakat.AlIslam.com/def/ (printed 25 January 2001).

61 For a list of projects and achievements inside Kuwait, see "Activities of Zakah House," http:/ / zakat.Al-Islam.com/def/ (printed 25 January 2001). However, I have not been able to locate a list or presentation of projects outside Kuwait financed through funds provided by the Kuwaiti Zakah House. During my fieldwork in Ghana, I noticed that some of the Muslim NGOs receive substantial financial backing from the Kuwaiti Zakah House. 
(The Kuwaiti Zakah House) is considered the first organisation in the Arab World that adopts scientific application of the obligation of Zakah, including collection and distribution, publishing related books, information and fatāwin and conducting social studies to identify those entitled to receive Zakah. 62

In fact, one could argue that such an organisation is in one sense rather similar to Western charitable organisations, such as the various Catholic relief organisations (Caritas), Oxfam or the Red Cross. However, in one perspective a zakāt committee differs from these Western organisations, namely in its role for channelling obligatory alms. Further, the Kuwaiti Zakah House, like similar zakāt organisations, is a public but independent organisation. In Kuwait, the organisation is under the supervision of the Ministry of Awqaf and Islamic Affairs, the Minister of Awqaf and Islamic Affairs heading the board of the organisation. However, as an independent body, the Kuwaiti Zakah House cannot implement zakāt as a tax (which is ruled out by the fatāwin produced by its scholars). Instead, the resources of the Kuwaiti Zakah House are made up from free contributions_zakāt—of individuals and groups, endowments and donations received by the board of directors from other public organisations and institutions, associations, companies and individuals as well as subsidies provided by the State. ${ }^{63}$

A similar picture prevails in other Gulf countries. As in Kuwait, zakāt is not compulsory but paid voluntarily by the Muslim citizens of Bahrain and the United Arab Emitrates. In Bahrain, zakāt is collected by a "semi-governmental" body, the zakāt fund, which was established in 1979. However, as in Kuwait, this body is not entirely independent as there are links to the Ministry of Justice and Islamic Affairs and its board comprises both citizens and officials. The basic funding is generated through voluntary contributions, but, as Sani Ali Eid, the director of Islamic Affairs at the Ministry of Justice and Islamic Affairs, underlined in an interview, "the government helps in the collection and distribution of zakāt." 64

The United Arab Emirates (UAE) is home to many charitable and humanitarian organisations, some semi-governmental, like the Dubai Charity Organisation (DCO), whereas others are non-governmental ones, like the Red Crescent Society (RCS), Charity International, and Human Appeal International (HAI). Although most of these organisations are said to be NGOs, government involvement seems to occur in most of the big organisations as every three years the Ministry of Labour together with the Diwān (Ruler's) Office appoint a few officials to represent a board which oversees the activities of each charitable organisation in the country. Most of the fund-raising

62 “The Role of the Zakah House, http: / / zakat.Al-Islam.com/def/ (printed 25 January 2001).

63 "The Decree of establishing Zakah House," http://zakat.Al-Islam.com/def/ (printed 25 January 2001).

64 Chand, Indira, "Public confidence needed in zakah organisation," http:/ / www.Islamiq. Com:/news / features / print.php4?news=1_04102000 (published 4 October 2000; printed 6 June 2001). According to Sani Ali Eid, the Bahrain zakāt fund is mainly engaged in supporting poor families. During the year 2000, some 2,165 families received help. 
activities and the payment of zakāt occur during Ramadān. As in Bahrain and Kuwait, however, zakāt is a voluntary or private matter, being collected through collection boxes that are made available at all the mosques, major shopping centres and other similar outlets. 65

However, whereas one could argue that the collection of zakāt in rather affluent and oil rich Arab countries has resulted in the establishment of public, but independent governmental zakāt organisations, such conditions do not prevail in most other Muslim countries. In Morocco, for example, there has been a discussion about turning zakāt into an effective tax on the better off to help homeless and disabled poor children. ${ }^{66}$ In contrast to Kuwait, the Moroccan debate is about whether zakāt should become a tax-once again. In fact, it was only during the seventeenth century that the Moroccan state transferred the duty of collection and distribution of zakāt to the local imāms. ${ }^{67}$ What remained of zakat in the public sphere was lost during the French protectorate and today zakāt is perceived by most Moroccans as 'alms'. But with the rise in population and the poor economic foundation of the country during the latter half of the twentieth century, street children and poverty became widespread. Yet, before 1998 and the demand of the reintroduction of zakāt as a-social-tax, only a few Muslim NGOs tackling social matters existed and those who did concentrated their efforts on the cities. 68

Some twelve years later, it seems as if not much has been done. According to Jamal En-Nehas, despite the interest expressed by the late king Hussein II to have zakāt formalised, "the idea is still in an embryonic stage." The idea of King Hussein was to set up collection and distribution banks as well as put forward a plan whereby zakāt, in emulation of income tax, could be deducted from government pay cheques-a similar procedure to the one in Pakistan at present. However, due to technical and logistical difficulties and above all the reluctance and distrust of the Muslim population towards a state supervised collection of zakāt, the collection and distribution of zakät has so far remained largely a private matter. Thus, En-Nehas is rather critical about the use of zakāt as a tool to provide social welfare in Morocco:

It is uncommon to see zakah payers co-ordinating their efforts to collect and channel funds judiciously in the general interest of the nation. [...] One of the immediate consequences of this situation is the inefficient management of zakah resources, which often results in its arbitrary distribution and the lack of a clear Islamic welfare vision. 69

65 Abdalla, Cindy, "Zakah distribution in the UAE," http://www.Islamiq.Com:/ news/ features/print.php4? news=1_27102000 (published 27 October 2000; printed 6 June 2001).

66 Al-Ali, Nizar, "Traditional Islamic Alms Help Street Children," http: / / www.oneworld.org /ips2/jul98/13_23_039.html (printed 16 March 2000).

67 Rodriguez-Manas 1966.

68 Al-Ali, Nizar, “Traditional Islamic Alms Help Street Children”.

69 En-Nehas, Jamal, "Reflections on zakah in Morocco," http://www.Islamiq.Com:/news / features / print.php4?news=2_18082000 (published 18 August 2000; printed 6 June 2001). 


\section{Muslim NGOs and the Collection of Zakāt}

As the fatāwin referred to above have stated, Islamic governments are obliged to establish a special organisation for collecting zakat. In non-Islamic or nonMuslim countries, the duty to collect zakāt is said to be transferred to nongovernmental societies or NGOs. Such a situation is a rather new one. Muslim NGOs engaged in collecting zakāt have existed since the 1980s; in fact, almost all of those societies that could be located on the internet have been established during the last twenty years or so. However, Muslim societies engaged in social welfare projects are nothing new. In Egypt, for example, there exists a range of organisations that have been engaged in social welfare projects for a long time. ${ }^{70}$ Of equal importance, although most often forgotten in modern discourse, has been the traditional way of providing organised social welfare through awqāf establishments and through the Sufi orders. ${ }^{71}$

Especially in non-Muslim countries, the local mosque has been and continues to be the foremost institution to collect and distribute zakät. Other avenues have been and are the Islamic schools, and a third way has been for people to send zakat back to their families and communities in their home countries. However, since the 1980s Muslim NGOs and relief organisations in the West (USA, Canada, UK) have become an increasingly popular avenue of zakat collection and distribution. This development reflects the situation of the Muslim communities in non-Muslim countries: as there is no governmental or state engagement in the collection and supervision of zakāt, the Third Pillar becomes a private matter. Or, as the Islamic Circle of North America (ICNA) has underlined, "... if there is no alternative available, it is permissible to take out zakah and to distribute it on an individual basis." 72

The difference between these older establishments and the modern Muslim NGOs seems to be their stress on the collection and distribution of zakāt as well as their link to the government or position as an 'official' though independent body. Last but not least, the trade mark of modern Muslim NGOs seems to be their use of Western vocabulary as well as modern techniques-above all the internet, thus being in the end equal to Western NGOs in terms of objectives and means. Such a situation becomes especially widespread in the USA, Canada and the UK, where there exists a great variety of Muslim NGOs. Some of the Muslim umbrella organisations do not claim to collect and distribute zakāt, whereas others do. For example, the Islamic Society of North America (ISNA), demonstrates typical activities of a

\footnotetext{
70 See further Sullivan 1994. For a discussion on Islamic economics and Islamic social welfare institutions in Egypt, see Wippel 1995.

71 See, among others, Kogelmann 1999. On the provision of social welfare through waqf institutions, see further Kogelmann in this volume (Chapter III); on the role of Sufi shaikhs and orders, see the contributions of Vikør (Chapter IV), Seesemann (Chapter V) and Loimeier (Chapter VI).

72 Quoted in Baroud, Ramzy, "Alternative avenues for zakah collection in the US," http:// www.Islamiq.Com:/news/features/print.php4? news=1_10012001 (published 10 January 2001; printed 6 June 2001).
} 
Muslim NGO. Apart from giving support to schools and community centres, the ISNA has a so-called Zakah Fund:

The Zakah Fund is maintained by donations of individuals and affiliates. It is designed to help the needy, orphans, and any person who qualifies, according to the guidelines, for receiving Zakah.73

However, it could be claimed that the call for donations by individuals would rather resemble șadaqa—or voluntary almsgiving — than zakāt.

In general, Muslim Relief Organisations claim to collect and distribute zakat. ${ }^{74}$ Compared with the outlook of the ISNA, international Muslim Relief Organisations openly invite Muslims to donate their annual zakāt to them. Thus, Care International, for example, a US-based Muslim NGO founded in 1993, provides a sophisticated online 'Zakat Calculation Guide' and declares that

... Care's projects range all the way from distributing Zakat money amongst its rightful receivers to distributing Udhiyas (Qurbanis) amongst the needy. ${ }^{75}$

Similarly 'Interactive Zakat Worksheets' and 'online payment' of zakāt are provided by, among others, the Global Relief Foundation, ${ }^{76}$ the Islamic Circle of North America (ICNA Relief-Helping Hand), ${ }^{77}$ Human Concern International, ${ }^{78}$ Islamic Relief, ${ }^{79}$ and Muslim Aid. ${ }^{80}$ National Muslim NGOs, such as Zakat Fund, a Lebanese 'humanitarian philanthropic establishment', ${ }^{\prime 1}$ Qatar Charity Society, ${ }^{82}$ and Crescent Medical Aid Kenya also collect $z a k \bar{a} t .{ }^{83}$ Other online zakāt-collecting organisations have a more national focus

\footnotetext{
73 See further http:/ www.isna.net/services.asp.

74 For a list of Muslim Relief Organisations in North America, see http://msa-natl.org/ resources/Relief_Orgs.html.

75 See further http: / / www.care-intl.org.

76 See further http: / / www.grf.org/helpnow-zakat.asp.

77 See further http: / / www.icna.org/Zakat.

78 See further http:/ / www.humanconcern.com. This organisation was founded in 1980.

79 See further http:/ / www.irw.org/help/index.htm. Islamic Relief is a UK-based international relief and development organisation founded in 1984. The organisation is a member of the International Islamic Committee for Relief under the auspices of Al-Azhar and has a consulting status with the Economic and Social Council of the United Nations. In fact, Islamic Relief does not openly declare it collects and distributes zakāt but solicits Muslims for 'donations'.

80 See further http:/ / www.muslimaim.org/. Muslim Aid is an UK-based international relief organisation. It was founded in 1985.

81 See further http:/ / www.zakat.org.lb/. The organisation was founded in 1984.

82 See further http:/ / www.qcharity.org/.

83 See further http://www.crescent-medical-aid.org/zakat.html. This organisation was already established in 1976.
} 
of their activities, such as Muslim Welfare Center (Canada) and Life for Relief and Development (USA and Canada). ${ }^{85}$

As noted above, the structures of the various Muslim Relief Organisations are similar to those of Western Relief and Development Organisations. Assistance is given both in terms of emergency relief as well as through development projects and programmes, focussing on the promotion of social welfare in local societies. Some of the Muslim NGOs focus on providing help to Muslim societies, including the establishment of mosques, community centres and education programmes, whereas others, such as Muslim Aid, claim to help 'the poor and the needy regardless of race, ethnicity, colour or religion'.

Muslim NGOs, like Western NGOs, are visible signs of an emerging civil society. In Western non-Muslim countries, Muslim NGOs are able to act within Western civil society-raising funds and presenting a Muslim alternative to the public sector. This is also the case in the societies and regions that receive help-NGOs working within a particular state, not through or with the state's assistance but mostly with its official blessing. Muslim NGOs have thus become or are about to become a substitute for public social welfare, in some cases replacing the state as the provider of collective social welfare.

Especially in an Islamic context, the role of the NGOs is problematic. Some scholars, such as Shaikh Omar Bakri Muhammad in the UK, criticise the activities of the Muslim NGOs, especially those who claim to collect zakāt. Only an Islamic state can collect zakāt and it should be the responsibility of the Islamic state to care for social welfare:

\footnotetext{
As for sending the army of Jihad to fight the disbelievers, punishing the apostates and the rebels of those liable for punishment, sending the money of the Bait-ul-Maal to the eligible recipients, collecting Zakat from those liable to pay it, appointing judges and governors, dividing the booty or signing treaties and truces, these are all the responsibility of the Khalifa alone or his appointees and are not permitted for anyone else...

The continuous management of the affairs of the Muslim Ummah e.g. to govern them by Islam, implement the penal system, impose judgements on them, declare offensive Jihad, enter into treaties, build motorways, hospitals and schools, collect and distribute Zakat etc $\ldots$ is the duty of the Khalifah alone i.e. the Islamic State. ${ }^{86}$
}

His main critique and disapproval concerns Muslim charitable organisations:

From the moment the Islamic state was destroyed until today we have heard some very strange Fatwas and opinions far removed from Islam and legitimate Ijtihad and concerning clear-cut text...[among others] permitting charitable organisations to look after the affairs of the people by taking over the role of the state, for example, collecting

\footnotetext{
${ }^{84}$ See further http: / / www.muslimwelfarecentre.com.

85 See further http: / / lifeusa.org.

86 Muhammad, Omar Bakri, "The Status of Charity Organisations in Islam," in: http:// www.as-sahwa.com/leaflets/118/index.htm, 3, 8 (printed 16 March 2000).
} 
Zakat with the lame excuse that we must find a practical alternative whilst the Khalifa is absent. 87

Most of the Muslim NGOs deduct some percentage of their income to pay for employees and cover their administrative expenses. ${ }^{88}$ According to the argumentation of the NGOs, they are allowed to do so even from an Islamic perspective as the rules of zakāt grant the collectors a share of zakāt. Shaikh Omar Bakri Muhammad, however, disapproves:

The False 'Aamileen A'liyha, the so-called collectors from charitable organisations such as Muslim Aid and Islamic Relief, are not included in the above verse [referring to sura 9: 60, HW] nor are they $\mathrm{Al}^{\prime}$ Aamileen A'liyha i.e. those appointed by Al-Khalifah to collect and distribute Al-Zakat. ${ }^{89}$

Thus, the opinion of the Shaikh concerning Muslim NGOs is a negative one, as these organisations seem to replace the state and take over state responsibility. On the other hand, one could argue that the Shaikh represents a Maliki interpretation, i.e., one that argues for a decisive role of the state with regard to the collection and distribution of zakāt. ${ }^{90} \mathrm{~A}$ counter-argument is provided by those NGOs that refer to a Hanāfī or Shafī ${ }^{-} 1$ interpretation:

If there is no alternative, it is permissible to take out Zakat and distribute it on an individual basis. But efforts should always be made to collectivize the giving of Zakah in order that its distribution be conducted systematically. ${ }^{91}$

Similar critical interpretations by Muslim scholars concerning the use of zakāt funds and their collection through organisations are rather general. In most cases, the debate is about whether organisations are in the position to collect and distribute $z a k \bar{a} t$ as they would replace the effort of a pious act of an individual to another individual. Another question has been whether zakāt money can be given to construct mosques, schools and hospitals. ${ }^{92}$

\footnotetext{
87 Muhammad, "The Status of Charity Organisations in Islam," 6.

88 According to the information given by Muslim Aid, the organisation disburses 87 per cent of all donations.

89 Muhammad, "The Status of Charity Organisations in Islam," page 7. A similar conclusion was reached by one mufti Taqi Usmani:

"It is not permissible for such private organisations to spend the zakat money to cover their administrative costs. ... It is applicable only in the context of an Islamic State which duly manages collection and distribution of zakat. This principle cannot be extended to the employees of private organisations."

However, according to the mufti, it is permissible for Muslim NGOs to collect and distribute $z a k \bar{a} t$ money as long as they observe the rules of zakāt. See further Usmani, Taqi "Use of Zakat for Administrative Expenses of Charities," http:/ / www.albalagh.net/qa/zakat_administration _expenses.shtml (printed 22 January 2001).

90 In fact, Shaikh Omar himself points towards such an interpretation, saying that "Muslims with their slave mentality continue to talk about benefit and interest and continue to distort the Maliki school of thought and its adoption of Al-Masaalih Al-Mursalah (p. 5)."

91 See further http:/ / www.icna.org/Zakat/, and http:/ / www.care-intl.org/islam/zakatFiqh. html.

92 See, among others, http: / / www.zpub.com/aaa/ zakat-india.html as well as Weiss 2000.
} 
A third, and increasingly debated matter, especially among Muslim scholars in the West, is the question of the use of modern technology, such as telephones and the online collection of zakāt. According to Ramzy Baroud, online zakät payment has opened a limitless window of opportunity for the collection and distribution of zakāt in general and Muslim NGOs in particular:

Internet users can now simply browse through various web sites, pick up the organization of their choice and deposit their zakah contribution, safe in the knowledge that it will be distributed to the needy. 93

Concerning the matter of zakāt collection by private organisations, one US mufti, Muzammil Siddiqi, stressed in a fatwa $\bar{a}$ the obligation of the donors to check the background of these organisations and to make sure that zakāt is dispersed according to Islamic principles, underlining that "once zakah is donated through reliable and trustworthy institutions, it is paid." Thus, in this respect Mufti Muzammil takes a positive stance on the question of Muslim NGOs collecting zakāt. Still, as Baroud notes, one key problem is that there is no precise scale to monitor which organisations are trustworthy and reliable, the only possibility being a maximum amount of transparency, as some authors have claimed. ${ }^{94}$

\section{An Islamic State? The Malaysian Example with a Note on Singapur}

Whereas the collection and distribution of zakāt through Muslim NGOs might open the way for an emerging Muslim civil society, in other regions a different approach towards the handling of zakāt has been applied, namely that of direct state supervision. Although it could be argued that such a system would come close to meeting the demands of the critics of Muslim NGOs, a state-controlled system is itself not lacking its drawbacks and critics, as the research of James Scott on Malaysia implies. ${ }^{95}$ In Malaysia, each of the 14 Islamic Councils established zakāt collection centres during the early 1990s. Whereas the Islamic Councils of the 13 states handle the collection and distribution of zakatt, the Islamic Council of the Federal Territory has set up a special collection centre, the PPZ or Pusat Pungutan Zakat. As in Kuwait, the Islamic Councils are not part of the Federal or State government nor is the collection of zakāt directly a state matter. Indirectly, however, the Islamic

93 Baroud, Ramzy, "Channels to distribute Zakah in Canada," http:/ /www.Islamiq.Com: /news/features/print.php4?news=1_19012001 (published 19 January 2001; printed 6 June 2001). A similar testimony for the UK is put forward by Najat Rashid, "for younger Muslims the cyber-age has provided them with a suitable alternative. Donations via telephone or increasingly, the internet are the most popular alternative forms of zakah payment in the UK." See further Rashid, Najat, "The Changing Trends of Zakah Collection and Distribution in the UK," http:/ / www.Islamiq.Com:/ news/features/print.php4?news=1_13032001 (published 13 March 2001; printed 6 June 2001).

94 See further Baroud, "Alternative avenues for zakah collection in the US".

95 See further Scott 1987. 
Councils have a close link to the government as they have been established either through Federal or State Legislation. Thus, with regard to zakāt, one could claim that the state has transferred the obligation of collecting and distributing zakāt to the Councils; the Councils being responsible to the Sultan or Ruler of each State. ${ }^{96}$

There is one obvious difference between the Muslim NGOs and the Malaysian case in the collection of zakät, namely in its calculation. Whereas the Muslim NGOs use a uniform flat rate of 2.5 per cent (or, if referring to donors in general, an unspecified amount of money), the calculation of zakāt in Malaysia follows the outlines of the zakāt-rules, namely including zakāt on crops (five to ten per cent) and on livestock (rate depending on the type of animal). Furthermore, at least in theory, savings, businesses and shares should also be zakatable ${ }^{97}$ However, in practice, zakat on wealth has been irregular and there are plans under way to make it compulsory for Muslims to pay zakāt from earnings, savings and businesses. In a press release in January 2001, government sources reported that only ten per cent of the annual zakāt collection is from Muslim business enterprises and corporations, thus indicating that the burden of zakāt so far has lain on individuals. However, although zakāt on wealth is collected, only zakat fitrah (zakāt al-fițr) or zakāt collected during the month of Ramadan is compulsory under Malaysian law. ${ }^{98}$ However, zakät al-fitr only amounts to about 4 per cent of the total amount of zakāt collected ${ }^{99}$ According to official statistics, zakāt amounting to a total of RM 203 million was collected during 1997, whereas it is calculated that the potential could be RM 300 million for the whole country. ${ }^{100}$

According to data published by the PPZ, the collection of zakätexcepting zakāt al-fitr -in the Federal Territory amounted to about RM 43.3 million (about $£ 6.8$ million) in 1998. This amount can be compared to the donations to Muslim Aid, which were about $£ 2.8$ million for 1998/99. However, due to the economic turmoil and downturn in Asian economies, the amount of zakāt has decreased; during 1997 the FT Islamic Council had received about RM 50.3 million. ${ }^{101}$ On the other hand, the rate of zakat collection for the whole decade shows a remarkable increase in zakat for the PPZ_-starting with RM 13.5 million and 11,816 payers during 1991 to RM 43.6 million and 23,618 payers during $1998 .{ }^{102}$

\footnotetext{
96 See further http: / / www.zakat.com.my. This site provides detailed information on the PPZ, including annual reports.

97 See further http: / / www.zakat.com.my/understand_zakat.htm.

98 Wahab, Adlina, "Zakat payment to be must," http://www.zakat.com.my/press_zakatpay. htm (printed 25 January 2001).

99 Numbers available only for the PPZ, see further http:/ / www.zakat.com.my/performance _wealthFT.htm.

100 See further http: / / www.zakat.com.my/performance_estimate.htm.

101 See further http: / / www.zakat.com.my/performance_media.htm.

102 See further http://www.zakat.com.my/performance_trend.htm. During the top year, 1997, almost 30,000 payers paid RM 50.6 million in zakāt.
} 
Hajj Mohamed Dahan attributes the low result of payment of zakāt on wealth to the lack of an organised system of collection as well as distribution. Although there exists an officially authorised super-structure, such as the PPZ and the various other zakat funds of the Islamic Councils, problems arise on the local level as well as in those communities not properly organised (although in this case Dahan seems to speak in general terms and not refer to the case of Malaysia). In general, however, Dahan raises an argument for the establishment of a proper zakät administration and authority, either through the government or, in the case of a non-Muslim country, the local Muslim community:

\begin{abstract}
If a community has agreed generally that a certain organisation should be responsible, then zakat should be channelled to it. The organisation must then organise the programs and channel of distribution, within the prescribed categories. Administration costs for example are allowed, but must never exceed $1 / 8^{\text {th }}$ of total zakat available. Paying direct to the needy individually would not create long term and sustained benefits, and there won't be a zakat institution to be responsible overall [emphasis mine, HW]. ${ }^{103}$
\end{abstract}

The collection and distribution of zakāt is handled in a similar way in Singapur. Established in 1968 as a statutory body by the government, the Majlis Ugama Islam Singapura (MUIS or the Islamic Religious Council of Singapur) is entrusted with collecting both the zakāt al-fitr as well as the zakāt on wealth. MUIS is under the auspices of the Ministry of Community Development and Sports and has access to the government's Muslim database to promote the collection of zakāt. Zakāt can be paid either in cash to one of the 62 collection centres that are located at various mosques and Islamic organisations, or by cheque, money order or bank draft payable to MUIS. In addition, there exists a "zakah hotline", where zakāt can be paid over the phone. However, as in Malaysia, state collection of zakāt still needs to be rooted among the population. Vardan notes that only some 12 per cent of a Muslim working population of some 130,000 persons in Singapur actually pay zakāt and that the majority of the zakāt payers are above 40 years old. ${ }^{104}$

The above examples seem to point to the fact that state collection of $z a k \bar{a} t$ does not seem to be too popular-at least not in the cases so far discussed, namely Pakistan (see footnote 43), Malaysia and Singapur. Some Muslim jurists, such as Shaikh Nedham Yaquby, even claim that the state should not be involved at all in the collection and distribution of zakat. Shaykh Nedham prefers no government interference at all: "Governments should, in fact, stay out of the collection and distribution of zakah, if zakah funds are to enjoy public confidence," and he points to the fact that "people, generally, don't have confidence in bureaucracy." 105

103 Dahan, Haji Mohamed, "Zakat in Malaysia”, http://www.zpub.com/aaa/zakat-2.html (printed 16 March 2000).

104 Vardhan, S., "Zakah in Singapore: Riding on Technology," http://www.Islamiq.Com: /news/features/print.php4?news=1_05012001 (published 5 January 2001; printed 5 June 2001). See also http:/ / muis.gov.sg.

105 Quoted in Chand, "Public confidence needed in zakah organisations". 


\section{The Situation in West Africa: A Plea for Further Research}

So far the collection and distribution of zakāt has been discussed in a nonAfrican Muslim context. Outside sub-Saharan Africa, a wide range of semigovernmental as well as non-governmental organisations and zakāt bodies have been identified and presented. Thus, there should be no doubt about the existence of zakat in the modern Muslim world. What seems to be the crucial debate about zakät is whether it should be handled as a private or a public matter, especially if the collection and distribution of zakät should or could be systematised and institutionalised. At least two models can be outlined, one where zakat is collected and distributed by independent bodies and the other where the government is at least to some extent engaged in the collection and distribution of $z a k \bar{a} t$. The dividing line seems to be whether one is dealing with a Muslim or a non-Muslim society. However, what seems to be of particular interest is the fact that none of the public institutions discussed have been established within or by an Islamic state-such a state being, so far, a more or less theoretical construct. On the other hand, what is evident from the discussion above is the impetus by some Islamic economists and Muslim scholars to combine Islamic economics with the requirement of establishing an Islamic order and an Islamic state. Within such a discourse, zakāt inevitably becomes part of a political discourse, namely that of Islamism.

Compared with the rest of the Muslim world, the position of zakat in subSaharan countries and Muslim societies is not well known. Zakät was part of the public sphere in several pre-colonial Muslim states of the Sudan savannah, such as the Diina of Masina, the Sokoto Caliphate and the Mahdiyya in the Nilotic Sudan, although not much is known about its actual collection, distribution and impact. ${ }^{106}$ The various colonial regimes abolished zakāt as a tax throughout their realms and almost none of the post-colonial states have reintroduced zakāt as a tax-one notable exception being the Sudan.

However, apart from being applied as a tax in pre-colonial Muslim states, zakāt was part of the Islamic order that was established and prevailed in Muslim enclaves and communities, such as the estates of holy men, Sufi shaikhs and learned men. These enclaves and communities existed throughout Sudanic Africa, both in Muslim and non-Muslim states. A general feature of these enclaves was that the scholars or holy men had been granted tax exemptions by the local rulers, thus becoming in economic terms autonomous from the local ruler. However, an Islamic order was usually established within their communities, one visible sign being, among others, the payment of zakāt to the holy men or the local imam, who in his turn would distribute it to those in need. ${ }^{107}$

The post-colonial situation concerning zakāt in sub-Saharan Africa is somewhat puzzling, not least due to the lack of research and insight on this

106 See further Hunwick 199 and Weiss (forthcoming).

107 This subject is discussed in the seventh chapter of my forthcoming monograph. 
subject. It is known that zakāt is collected in Northern Nigeria-at least in Kano state there existed at the beginning of the 1990s an organisation called Kano State Council for Zakat Collection and Distribution, ${ }^{108}$ and it is known that the payment of zakāt was not questioned by Hausa businessmen, ${ }^{109}$ but not as a tax-rather as a religious contribution. It seems as if there has been an attempt to centralise the collection and distribution of zakāt in Northern Nigeria since the 1960s. One of the achievements of Ahmadu Bello, the Sardauna of Sokoto, through the establishment of the Jama $\bar{a}^{c} a t$ Nasr al-Islam, the Society for the Support of Islam or JNI, which was planned to become a platform for and unite the various factions of Muslims and the various Sufi orders during the early 1960s, was to establish the yearly rates (nisab) of zakat. ${ }^{110}$ However, the functions and impact of the zakat organisation in Kano and other places have not been studied. One could also argue that the upsurge of Islamic economics in some Nigerian universities, especially Usmanu Danfodio University at Sokoto, during the 1980s and 1990s or the arrangements of national seminars on zakāt, such as the one organised at Bayero University in Kano during 1982, and learned articles on zakät by Muslim scholars in the newspapers, are all signs that the prevailing conditions in Northern Nigeria are felt by Islamic scholars to be insufficient. ${ }^{111}$

However, although in Northern Nigeria the introduction or adoption of the $\operatorname{shari}^{c} a$ in some Northern states during the first years of the third millennium $\mathrm{AD}$ might create space for the introduction of an Islamic economy, the secession of some of the Northern state of Nigeria and fear (or fear of the possibility) of the establishment of an Islamic state is contested by academic observers. ${ }^{112}$ The foundations as well as outlook for the Nigerian economy have been rather weak since the downturn during the 1980s and Structural Adjustment Programmes and other imposed economic and fiscal pressures on the common people have added to their plight. There exists neither a state-run (public) social welfare programme nor an efficient competing Muslim one. Private Muslim NGOs and establishments do exist, building and running mosques, educational programmes, schools and institutions as well as health clinics, orphanages and nurseries, but seemingly without any central coordination. ${ }^{113}$ In fact, along with the implementation of Islamic Law, most of the Northern states have also set up zakāt funds. Thus, for example Kebbi, Bauchi and Borno states are said to have formed committees that would be responsible for the collection and distribution of zakatt, indicating, on the one

\footnotetext{
108 Reference found in a local newspaper, The Triumph 9.6.1990.

109 Blanckmeister 1992, 26-27.

110 Until the late 1980s, however, the JNI had been blocked as a platform for all Muslims because of the internal conflicts between the Sufi orders and the Yan Izala-movement. See further Loimeier \& Reichmuth 1993, 48; Loimeier 1997.

111 See further my discussion in Chapter VIII as well as Abun-Nasr 1993, 217, 222.

112 See Ifeka 2000. For further details on the introduction of $\operatorname{shari}^{c} a$ in Nigeria, see "In God's Name", Africa Confidential, 41:5, March 2000.

113 Oral information. This question will be investigated in future research by the author.
} 
hand, that state supervision so far has been absent and zakāt has been a voluntary and private matter, and, on the other hand, an attempt by the governments to implement what they perceive as an Islamic policy. ${ }^{114}$ The expectations are high, as Qādī Marafa in Bauchi explained in an interview: "Sharia would wipe out begging and all forms of destitutions as a welfarist system would be created where zakat would be collected to help the needy."115

A similar situation in terms of haphazard or non-institutionalised and non-centralised implementation and running of social welfare institutions prevails among the Muslim community in Ghana. ${ }^{116}$ However, whereas some Muslim scholars in Nigeria loudly demand the Islamisation of Nigerian society or at least the North, such demands are not made by Ghanaian scholars. A comparison of the two cases reveals some similarities: both states are officially secular, both states have been hit by economic recession (Ghana during the 1970s and early 1980s and again since the late 1990s, Nigeria since the 1980s), in both states the North is perceived as backward and 'Muslim'. However, there is one major difference between the Nigerian and the Ghanaian cases: whereas the Sokoto Caliphate is referred to as the glorious past and source of inspiration and guidance for a future Islamic society in Northern Nigeria, no such historical example exists for Ghana.

Although the call for Islamisation and the establishment of an Islamic order is evident in many sub-Saharan African states, one could argue that, in terms of the establishment of an Islamic social welfare system, there exist several possibilities. One would be the establishment of an Islamic state, although this option does not look too feasible given the fact that almost all states are at the moment secular ones and include substantial numbers of different religions and conflicting political agendas. One precondition for the establishment of an Islamic state must be consensus among the Muslims, and in most cases this is not found to exist. Thus, one could argue that the establishment of an Islamic economy is still in the remote future. However, turning to the example of the local tradition of accommodation as well as the modern implementation of the zakāt rules by Muslim NGOs, one could argue for an applied model to be implemented among Muslim societies in subSaharan Africa, namely that of the establishment of an Islamic order within the Muslim community but without the Islamisation of the state. Consensus

114 On Kebbi state, see "Obansanjo is honest", The News (Lagos) 26 April 2000, wysiwyg:/ / 85/ http: / / allafrica.com/stories/200004260262.html (printed 7 June 2001) and "Sharia: The Kebbi Experience", The Post Express (Lagos) 17 December 2000, http://allafrica.com/stories/ 200012180094.html (printed 7 June 2001); on Bauchi, see "Sharia: Bauchi, Gombe-the Dilemma of Two Sister States", The Post Express (Lagos) 14 October 2000, wysywyg://88/http:// allafrica.com/stories/200010140056.html (printed 7 June 2001)

115 Quoted in "Sharia: Bauchi, Gombe-the Dilemma of Two Sister States"; on Borno, see "Borno Assembly Okays 2000 Supplementary Bill", This Day (Lagos) 8 December 2000, http:/ / allafrica.com/stories / 200012080357.html (printed 7 June 2001).

116 See further Weiss 2000. For an outline and discussion about the impact of Muslim NGOs in Accra, see Mumuni's contribution in Chapter VII. 
among the Muslims is still needed: national zakāt boards or organisations can only effectively be established when there is consensus among the Muslims. It is the task of the Muslims to look for consensus; however, it could be the task of researchers to identify the possibilities, impact and drawbacks of various existing Islamic social welfare programmes.

\section{References}

www-files

Abdalla, Cindy, "Zakah distribution in the UAE", http:/ / www.Islamiq.Com:/news/ features/print.php4?news=1_27102000.

Al-Ali, Nizar, "Traditional Islamic Alms Help Street Children", http://www.oneworld.org/ips2/jul98/13_23_039.html.

Baroud, Ramzy, "Alternative avenues for zakah collection in the US", http:/ / www.Islamiq.Com:/ news / features/print.php4? news=1_10012001.

Baroud, Ramzy, "Channels to distribute Zakah in Canada",

http: / / www.Islamiq.Com:/ news/ features/print.php4?news=1_19012001.

"Borno Assembly Okays 2000 Supplementary Bill", This Day (Lagos) 8 December 2000, http:/ / allafrica.com/stories/200012080357.html.

Chand, Indira, "Public confidence needed in zakah organization",

http:/ / www.Islamiq.Com:/news / features/print.php4?news=1_04102000.

Dahan, Haji Mohamed, "Zakat in Malaysia", http: / / www.zpub.com/aaa/zakat-2.html.

Decrees issued by the Islamic Jurisprudence Academy of the Islamic World League, http: / / zakat.Al-Islam.com/def/.

Farhan, Muhamad, "The collection of zakah in Pakistan",

http:/ / www.Islamiq.Com:/news / features/print.php4?news=1_26092000.

Fatwa delivered by the First Zakah Conference, Kuwait 3 April 1984,

http:/ / zakat.Al-Islam.com./def/.

Fatwa delivered by the First Symposium of Zakah Contemporary Issues, Cairo 25 October 1988, http:/ / zakat.Al-Islam.com/def/.

Fatwa delivered by the Second Symposium on Zakah Contemporary Issues, Kuwait 25 June 1989, http:/ / zakat.Al-Islam.com/def/.

Fatwa delivered by the Third Symposium on Zakah Contemporary Issues, Kuwait 2 December 1992, http:/ / zakat.Al-Islam.com/def/.

Fatwa delivered by the Fourth Symposium on Zakah Contemporary Issues, Bahrain 29 March 1994, http: / / zakat.Al-Islam.com/def/.

Fatwa delivered by the Third Conference of the Islamic Bank held in Dubai, 23 September 1985, http:/ / zakat.AL.Islam.com./def/.

Fatwa delivered by the Islamic Jurisprudence Academy of the Islamic Conference Organisation in Jeddah, http: / / zakat.Al-Islam.com/def/.

Fatwa delivered by the Second Conference of the Islamic Research Academy in Cairo, http:/ / zakat.Al.Islam.com/def/.

Muhammad, Omar Bakri, (s.a.). "The Status of Charity Organisations in Islam", http:/ / www.as-sahwa.com/leaflets/118/index/htm.

En-Nehas, Jamal, "Reflections on zakah in Morocco",

http: / / www.Islamiq.Com:/news/features/print.php4?news=2_18082000.

"Obansanjo is honest", The News (Lagos) 26 April 2000,

http: / / allafrica.com/stories / 200004260262.html. 
Rashid, Najat, "The Changing Trends of Zakah Collection and Distribution in the UK", http: / / www.Islamiq.Com:/ news/ features/print.php4?news=1_13032001.

"Sharia: The Kebbi Experience", The Post Express (Lagos) 17 December 2000,

http: / / allafrica.com/stories/200012180094.html.

"Sharia: Bauchi, Gombe-the Dilemma of Two Sister States", The Post Express (Lagos) 14

October 2000, http: / / allafrica.com/stories / 200010140056.html.

Usmani, Taqi, "Use of Zakat for Administrative Expenses of Charities",

http: / / www.albalagh.net/qa/zakat_administration_expenses.shtml.

Vardhan, S., "Zakah in Singapore: Riding on Technology",

http: / / Islamiq.Com./ news / features / print.php4? news=1_05012001.

Wahab, Adlina, "Zakat payment to be must", http:/ / www.zakat.com.my/press_zakatpay.htm.

\section{Literature}

Abun-Nasr, Jamil (1993). "Islamisches Recht im nigerianischen Rechtssystem", in Muslime in Nigeria. Religion und Gesellschaft im politischen Wandel seit den 50er Jahren, Abun-Nasr, Jamil (Hrsg.), Münster; Hamburg, 201-225.

Ahmad, Mahmud (1992). Social Justice in Islam, Delhi, 3rd ed. (1st ed. 1982).

Ahmad, Ziauddin (1991). Islam, Poverty and Income Distribution, Leicester.

Aghnides, Nicolas (1916). Mohammedan Theories of Finance, New York.

Asad, Muhammad (1985). The Principles of State and Government in Islam, New edition, Gibraltar.

'Azīz, T. M. (1992). "An Islamic Perspective on Political Economy: The Views of Martyr Muhamma Bāqir al-Sadr", Al-Tawhìd, X:1, 139-54.

Blanckmeister, Barbara (1992). "Islam, Tradition und Ökonomie aus der Sicht nordnigerianischer Unternehmer", Afrika Spectrum, 27, 25-42.

Al-Buraey, Muhammad (1985). Administrative Development. An Islamic Alternative, London.

Chapra, M. Umer (1992). Islam and the Economic Challenge, Leicester.

Doi, 'Abdur Rahman I. (1984). Sharī'ah: The Islamic Law, London.

Feldbauer, Peter (1995). Die islamische Welt 600-1250. Ein Frühfall von Unterentwicklung?, Wien.

Gellner, Ernst (1981). Muslim Society, Cambridge/London/New York.

Hodgkin, Elizabeth (1998). "Islamism and Islamic Research in Africa", in Islam et islamismes au sud du Sahara, Ousumane Kane et Jean-Louis Triaud (eds), Paris, 197-262.

Hunwick, John (1999). “Islamic Financial Institutions: Theoretical Structures and Aspects of Their Application in Sub-Saharan Africa," in Credit, Currencies and Culture: African Financial Institutions in Historical Perspective, Endre Stiansen and Jane I. Guyer (eds), Uppsala, 72-99.

Ibn Khaldūn (1989). Prolegomena. Introduktion till världshistorien, translated by Ingvar Rydberg, Lund.

Ifeka, Caroline (2000). "Ethnic 'Nationalities', God and the State: Whither the Federal Republic of Nigeria?", Review of African Political Economy, No. 85, Vol. 27, 450-59.

"In God's Name," Africa Confidential, 41:5, March 2000.

Islahi, Abdul Azim (1988). Economic Concepts of Ibn Taiminah, Leicester.

Kogelmann, Franz (1999). Islamische fromme Stiftungen und Staat. Der Wandel in den Beziehungen zwischen einer religiösen Institution und dem marokkanischen Staat seit dem 19. Jahrhundert bis 1937, Würzburg.

Kuran, Timur (1986). "The Economic System in Contemporary Islamic Thought: Interpretation and Assessment", International Journal of Middle East Studies, 18, 135-64.

Loimeier, Roman (1997). “Islamic Reform and Political Change: The Example of Abubakar Gumi and the Yan Izala Movement in Northern Nigeria", in African Islam and Islam in Africa. Encounters between Sufis and Islamists, David Westerlund and Eva Evers Rosander (eds), London, 286-307.

Loimeier, Roman \& Stefan Reichmuth (1993). “Bemühungen der Muslime um Einheit und politische Geltung", in Muslime in Nigeria. Religion und Gesellschaft im politischen Wandel seit den 50er Jahren, Abun-Nasr, Jamil (Hrsg.), Münster; Hamburg, 41-82.

Mannan, M.A. (1970). Islamic Economics. Theory and Practice, Lahore.

Naqvi, Syed Nawab Haider (1981). Ethics and Economics. An Islamic Synthesis, Leicester. 
-, (1994). Islam, Economics and Society, London and New York.

al-Qardawi, Yusuf (1999). Fiqh az-Zakat. A Comparative Study, London.

Qutb, Sayyid (1953). Social Justice in Islam, translated by John B. Hardie, Washington.

Pfeifer, Karen (1997). "Is There an Islamic Economics?", in Political Islam. Essays from Middle East Report, Joel Beinin and Joe Stock (eds), Berkeley and Los Angeles, 154-65.

Reissner, J. (1991). "Die innerislamische Diskussion zur modernen Wirtschafts- und Sozialordnung", in Der Islam in der Gegenwart, W. Ende \& U. Steinbach (Hrsg.), München, $155-69$.

Rodriguez-Manas, Francisco (1966). "Supplanting the Ruler: The Levying of Taxes by Sūfi Zāwiyas in the Maghrib", Islamic Quarterly, XXXX:3, 188-99.

Ruxton, F.W. (1916). Maliki Law, London (reprinted 1989).

Al-Ṣadr, Muhammad Bāqir (1982). Iqtisādunā: Our Economics, Teheran.

Scott, James (1987). "Resistance without Protest and without Organisation: Peasant Opposition to Islamic Zakat and the Christian Tithe", Comparative Studies in Society and History 29:3, 417-52.

Siddiqi, S.A. (1948). Public Finance in Islam, Lahore.

Sullivan, Dennis J. (1994). Private Voluntary Organizations in Egypt: Islamic Development, Private Initiative, and State Control, Gainesville, Fl.

Ule, Wolfgang (1971). "Islam und Wirtschaft”, Der Islam, 47, 1971, 136-67.

Weiss, Holger, (2000). "Reflections on Zakāt in Northern Ghana: Not an Institution but a Goal to Be Achieved", Working Paper 2, University of Helsinki, Institute of Development Studies.

-, (forthcoming). Obligatory Almsgiving: An Inquiry into Zakāt in the Pre-Colonial Bilād as-Sūdān, Helsinki.

Wilson, Rodney (1998). "The Contribution of Muhammad Bāqir al-Ṣa,dr to Contemporary Islamic Thought", Journal of Islamic Studies, 9:1, 46-59.

Wippel, Steffen (1995). "Islam und Islamische Wirtschaft. Vertreter des religiösen und politischen Islam und die islamischen Wirtschafts- und Wohlfahrtseinrichtungen in Ägypten", Diskussionspapiere 45, Fachbereich Wirtschaftswissenschaft, Fachgebiet Volkswirtschaft des Vorderen Orients, Freie Universität Berlin.

Zubaida, Sami (1993). Islam, the People and the State. Political Ideas and Movements in the Middle East, London \& New York. 


\title{
CHAPTER II \\ Is There Room for Non-Muslims in the Sudan's Islamic Economy?
}

\author{
Endre Stiansen
}

\section{Introduction}

A burning issue in the debate on the Islamic state is the position of religious minorities. Much of the discussion has focused on constitutional issues and political rights. Among Muslims there are irreconcilable differences between two camps: orthodox proponents who argue that it is their religious duty to establish an Islamic state, even if it goes against the interests of religious minorities; and liberal opponents who reject the Islamic state because it would violate principles of equal rights for all citizens, including women and minorities. ${ }^{1}$ An important trajectory of this debate is the nature of the Islamic economy, and to what extent Islamic commercial legislation should apply to non-Muslims. It is not, however, an issue that has received much attention. In fact, the legal implications for non-Muslims are largely ignored both in standard works on Islamic economics and more specialised studies on Islamic finance and banking. This lacuna in the literature can partly be seen as a reflection of the agenda of the different authors: primarily they have been concerned with, first, establishing Islamic economics as a distinct research field, and, second, describing an (ideal) Islamic economy. Hence their concerns have not been to analyse practical problems that may follow from the implementation of their theoretical proposals. ${ }^{2}$ But in countries such as Iran (from 1979), Pakistan (from 1985), the Sudan (from 1983) and Afghanistan (from 1996), the Islamic economy is not just an idea since economic transactions are regulated by legislation inspired by the sharia.

\footnotetext{
${ }^{1}$ A compromise between the two positions has been proposed. Called "the Islamist modernist perspective", proponents recognise why "historical and religio-political factors" lead Muslims in a country such as the Sudan to aspire to have an Islamic constitution, but part company with traditionalists because they do not think this constitution should be based on the sharia as commonly understood. Rather, a contemporary Islamic constitution should be built on "the primary and fundamental message" of the Qur'ān and the hadiths of the Meccan period, and not "the subsidiary and transitional" message of the Revelation after the hijra to Medina. See An-Na'im 1985

2 This is not to say that there are no studies concerned with the operation of the Islamic economy, see Khan and Mirakhor 1987. Journals such as Journal of Research in Islamic Economics (Jeddah), Journal of Islamic Banking and Finance (Karachi), Journal of Islamic Studies, and American Journal of Islamic Social Sciences, regularly publish studies on different aspects of Islamic economics.
} 
The Sudan represents a unique case. The Salvation Regime under General 'Umar Hasan al-Bashīr (in power since a military coup in June 1989) has been unusually keen on enforcing Islamic laws also in the economic sphere, and the country has a large non-Muslim minority. An examination of the experience of the Sudan after the sudden Islamisation in 1983, therefore, gives one answer to the question whether or not there is room for non-Muslims in an Islamic economy. Yet an analysis of this issue should not be limited to the last two decades; in the northern part of the country scholars, judges and statesmen have had to deal with the legal position of non-Muslims since Islam became the dominant religion in the 16th century. Moreover, the core of their discourse is much older since the sharia sets the framework for relations between Muslims and non-Muslims. Hence this paper is divided in two parts. The first introduces the twin concepts "Islamic economics" and "the Islamic economy", and briefly recounts how the Sudan moved from theory to practice by introducing Islamic legislation. In the second part, the emphasis is on traditional legal practice and the process of legal reform from Independence in 1956 and to the present.

It is necessary to end this introduction with a note of explanation. A discussion of the non-Muslims in the Sudanese Islamic economy cannot concentrate on the production process; after all there is no distinctly Islamic way to grow cotton or durra, or to run a factory. Instead the focus must be on how nonMuslims have become subject to Islamic law, with its limitations on freedom of contract and prohibitions of certain economic activities, through the gradual expansion of the competence of the sharia.

\section{Islamic Economics and the Islamic Economy}

Islamic economics is a new concept. Emerging in India in the late colonial period, "the declared purpose of Islamic economics is to identify and establish an economic order that conforms to Islamic scripture and tradition", ${ }^{3}$ but at first leading proponents like Sayyid Abul A'la Mawdudi were more concerned with issues of "identity creation and protection" than to develop the economics of Islamic economics. ${ }^{4}$ This emphasis is not surprising given the intensity of local debates about causes for the perceived decadence of parts of Islamic society in India and how the Muslim community should be organised after independence. From the 1960s and 1970s Islamic economics has received increasing scholarly attention with a corresponding proliferation of studies. Yet the initial blending of political activism and theoretical exploration remains prominent since present-day academic champions of Islamic

${ }^{3}$ Kuran 1997, 301.

4 Kuran 1997, 302. 
economics often double as activists who portray the ideal Islamic economy as superior to other economic systems. This attitude is, for example, expressed in the implied juxtaposition of homo economicus and homo islamicus -while the former is "incorrigibly selfish and acquisitive", the latter is "just, socially responsible, and altruistic". ${ }^{5}$ It is important to note, however, that even scholars who are dismissive of the dominant consumer societies in North America, Europe and Asia, work within the neo-classical paradigm, and Islamic economics as a discipline (in a narrow technical sense) is therefore profoundly influenced by a western secular intellectual tradition.

Islamic economics is first and foremost inspired by the Qurān, but the traditions (sing. hadith) of the Prophet are also important. Economic issues are prominent in both sources, and commercial metaphors are often used to explain and illustrate general principles of Islam. ${ }^{6}$ Contemporary scholars refer much less to the figh literature. ${ }^{7}$ Since the founders of the four schools of law were concerned with the legality of various transactions in the market place, this is surprising and probably related to several factors. A few can be suggested here. First, the formative period of Islamic law did not produce one code of law, and on several issues there are considerable conflicts of interpretation among authoritative scholars. Second, the figh literature is firmly embedded in pre-modern societies, and legal scholars must use analogy ( $q i y \bar{a} s)$ to apply the law, as explained by the classical jurists, to every-day life in modern industrial and post-industrial societies. A third factor (that also holds true for the Qur'ān and hadiths) is that the figh literature does not provide a clear methodology for economic analysis. A consequence of the contemporary emphasis on the Qur'ān, and to a lesser extent the hadiths, is that the difference between sunni and shia legal traditions is clouded over, and scholars from both traditions construct their arguments on economic issues in much the same way.

Even though there is agreement that the Qur'ān provides the framework for proper economic behaviour, it is not an easy text to deal with because many general principles are couched in language that requires interpretation.

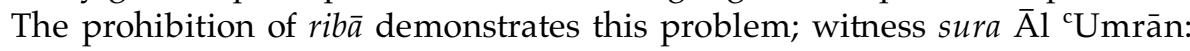
130

O you who believe, do not consume ribā with continued redoubling and protect yourselves from God, perchance you may be blissful.

Riba is a verbal noun meaning to grow, to increase or to get larger. The verse refers to the (widespread) practice at the time of the Prophet of money-lenders charging exorbitant interest rates which effectively trapped some borrowers in debt bondage. One interpretation of the verse is therefore to prohibit all

\footnotetext{
${ }^{5}$ Kuran 1986, 136.

${ }^{6}$ For a survey, see Hunwick 1999.

7 For a brilliant example of how the legal manuals can be used to "reconstruct" Islamic commercial law and practice, see Udovitch 1970.
} 
forms of economic exploitation, and in particular usury. ${ }^{8}$ Another interpretation is to regard the prohibition of ribe as the illegality of all gains from money-lending, i.e. all forms of interest. ${ }^{9}$ The two conflicting interpretations of the prohibition of rib $\bar{a}$ have radically different consequences for the organisation of an economy. In the first case, there will not be a substantial difference between conventional economies and an economy grounded in Islamic principles, provided adequate safeguards have been taken against exploitation. In the second case, all contracts and transactions that involve interest must be prohibited with the result that the financial system will be quite different from a conventional economy which allows interest; of course, economic exploitation will be prohibited in the interest-free Islamic economy too.

A different problem concerns what appears to be contradictions between different sections (or verses) in the Qur ān. For instance, in sura 9:35 it says that on the Day of Judgement the wealthy will be punished with the molten gold they have accumulated, while in sura 7:31 people are invited to wear and display their adornments and beautiful possessions. Clearly, a reasonable interpretation of the first verse is that wealth should not accumulate in private hands; possibly the verse can also be seen as the condemnation of unequal distribution of wealth within the community (the umma). On the other hand, the second verse seems to allow the assessment of private wealth, and by implication a non-egalitarian society. Although obsolete in a contemporary context, another example of ambiguity concerns slavery. While there is no doubt that slavery is permissible, slave owners are all the same encouraged to free their slaves. Hence, it is possible to base economic production in the Islamic economy on slave labour, even though it may be morally better to do without slaves. The legality of slavery seems to negate the general condemnation of exploitation.

Despite the possibility of conflicting interpretations, a majority of the advocates of Islamic economics are in agreement on a set of principles; the most important of these may be summarised as follows:

- private property is recognised and protected

- all member of the community (umma) should have their basic needs provided for

- production of non-legitimate (harām) commodities is prohibited

- sale of non-legitimate (harām) commodities is prohibited

- interest is prohibited.

In addition, most contemporary scholars argue that the core of an Islamic system of taxation should be the collection of zakat (an alms tax paid by the rich for the benefit of the poor); presumably non-Muslims would not pay zakāt but

\footnotetext{
8 Rahman 1964, 26-27.

${ }^{9}$ In this context the technical definition of riba is "a monetary advantage without a countervalue which has been stipulated in favour of one of the two contracting parties in an exchange of two monetary values", see Schacht 1986 [1964], 145.
} 
jizya (a poll tax). Moreover, in the Islamic economy inheritance would be regulated according to the detailed stipulations of the Qur àn, ${ }^{10}$ and production processes would be structured so as to allow Muslims to observe their religious obligations such as the five daily prayers as well as fasting during Ramadan.

\section{From Theory to Practice: The Sudanese Case}

In 1983, President Nimayrī introduced by decree a number of laws (subsequently somewhat incorrectly known as the September Laws) designed to make the judicature of the Sudan conform to Islamic principles. While the scope of the legal reform was extremely wide, ${ }^{11}$ only one section in the new Civil Procedure Act dealt with the financial sector; it simply stated:

Section 110: No decree of interest

The court shall under no circumstance whatsoever make a decree ordering payment of interest on the principle sum adjudged. ${ }^{12}$

Since the letter of the law did not explicitly rule out the continuation of interest payments (a borrower had to take his case to court for the law to be enforced), banking continued as usual, and it was only through additional provisions in the Civil Transactions Act (1984), and circulars from the Bank of Sudan, that existing loopholes were closed. ${ }^{13}$ In December 1984 banks were instructed to use Islamic forms of finance, with the result that bank lending began to take the form of mushāraka, mudāraba and murābaha contracts; correspondingly, interest bearing deposit accounts were converted into investment accounts, ${ }^{14}$ savings accounts, ${ }^{15}$ and current accounts. ${ }^{16}$ Enforcement of the interest ban, however, was careless, and in 1986 the democratically elected government allowed lending at fixed rates as compensation for inflation (see below for a discussion). Effectively this gave the public a choice between interest and noninterest banking. After the 1989 coup, the new Islamist government banned

10 A very large part of what can be considered Qur’ānic legislation addresses issues relating to inheritance.

11 Both substantive and procedural laws were affected, as well as criminal and civil legislation. For a survey of the legal issues, see Gordon 1985; and for a survey of the broader context, see Warburg 1990.

12 Arabic text: "cadam al-hakm bi-l-fāoida. La tahakum al-mahkama bi-l-fāa ida bi-āyyi hāal min al"ahwāl". The English wording of the subheading, which is rendered as published by the Justice Department, does not really convey the meaning of the Arabic; a better translation would be "no enforcement of interest" or "no judgements in support of interest".

13 For a more elaborate discussion of this subject, see Stiansen, 1999.

14 Money on account was used for targeted investments and could therefore make profits or losses.

15 Guaranteed accounts that would make profits in accordance with the bank's annual average return on capital, if any.

16 Usually these accounts were guaranteed but would not earn a return even if the bank was profitable. 
compensatory rates, and increasingly in the 1990s the Bank of Sudan, as regulator of the financial sector, has attempted to enforce the interest ban.

Two considerations carry equal weight in the choice of contracts in the contemporary Sudan: contracts have to conform to Islamic principles, and they have to meet pragmatic needs in concrete situations. Conventional contracts regulating wage labour, leasing and renting/letting are all compatible with Islamic law; financial instruments such as the bill of exchange (suftaja), cheque (hawāla or șakk) and draft (hawāla) are also legal. The need for distinct "Islamic contracts" is therefore largely restricted to situations where merchants and others in a different legal environment would have applied for loans. ${ }^{17}$

To avoid illegal interest payments, bankers can use the three basic contracts (or financial techniques) mentioned above: mushāraka, mud̄āraba and murābaha. The first is similar to a simple partnership or joint stock company; the second is equivalent to the commenda (sleeping partnership) as known in European commercial law; and the third is a re-sale with a mark-up. Of the three models, the first two are preferable because the financier ( $r a b b$ al-māl, "owner of the money") may make, or lose, money on his investment according to the success of the venture; hence he has no guarantee of a positive return on the investment. The third model is more questionable. Not only can the mark-up be calculated as if it were a running interest rate, to be legal the financier has to take physical possession of the item purchased on behalf of the customer, and this requirement has habitually been ignored by merchants and bankers in the Sudan. On the issue of the formulation of murābaha contracts, it should be noted that one interpretation of the law gives the customer, prior to taking actual possession of the commodity, the right to walk away from his commitment to the bank even if it has made the purchase. Initially this interpretation represented a marginal position, but after 1993 it has been enforced by the Bank of Sudan.

Agricultural finance represents a special challenge in an Islamic finance context, and particularly so in the Sudan because seasonal production, above all in the non-irrigated sector, depends on weather conditions. Because of the level of risk, financial institutions are reluctant to invest on the basis of partnerships or other profit-and-loss-sharing (PLS) models, and in general hedging (in a future market for agricultural commodities) is illegal because Islamic law "prohibits the exchange of abstract property for abstract property." 18 Yet the repertoire of Islamic contracts includes some that are well suited for the needs of agriculture. A salam contract is the sale of a fixed volume of next season's crop against immediate payment in cash; the contract also specifies quality as well as place and date of delivery. The difference between the salam price (when the contract was signed) and the market price (after harvest) represents the financier's profit or loss. (Salam contracts resemble

\footnotetext{
17 An interest-free loan is known as qard hassan, but it is regarded as an act of charity and therefore not important in the present context.

18 Vogel and Hayes 1998, 116. Future contracts are commonly used to hedge against financial risk.
} 
shayl contracts that for centuries have featured in the Sudan's economy. $)^{19} \mathrm{~A}$ muqāwala is another contract which can be used to finance the production process. The model is quite simple. A bank agrees to execute a certain task for a farmer (for instance to clear land or plant seeds) against payment in instalments or in a lump sum after a delay. ${ }^{20}$ Murābahas are also extensively used in agriculture because they are easy to administer, and in cases where the contract is used to finance capital investments, for instance tractors, the bank can retain title to the item in question until it has been paid in full. This reduces the element of risk quite substantially. These factors explain why murābaha contracts, in June 2000, accounted for roughly one half of all formal finance to the agricultural sector. ${ }^{21}$ The relative share of the different contracts does not reflect the government's preference, which favours the Islamically sound salam and mushāraka contracts.

The Sudan's experience with Islamic financial legislation is both complex and controversial. On the one hand, there is now ample evidence to demonstrate that Islamic financial techniques are sufficiently flexible to accommodate the requirements of a multiplicity of interests in a diverse economy. In some cases, for instance development finance, partnership finance may even be more suited to the needs of farmers or budding entrepreneurs than conventional interest-based finance. ${ }^{22}$ And because of the use of Islamic legal terminology, it is also possible to argue that the changes introduced in 1983 have gone some way to remove the sense of alienation conservative Muslims felt towards modern financial institutions. On the other hand, there does not seem to be evidence to suggest that the introduction of Islamic laws mitigated the element of moral hazard in financial transactions, since many banks have lost large amounts because of fraudulent behaviour by customers. It is also a fact that many bankers and bank customers find the Islamic models and techniques cumbersome when compared with conventional interestbased banking. At a different level, the banks have been criticised for failing to meet the moral and ethical standards of Islam when they take legal measures to enforce contracts. Salam finance is one case in point.

When introduced in advance of the agricultural season 1990/91, salam contracts were meant to serve two purposes: provide banks with a bona fide Islamic financial technique for agricultural investment, and facilitate more private investments in the agricultural sector. Not least because of a change in the Government's credit policy, the early 1990s saw a great increase in the amount of formal finance that went to agriculture. Annual production of food crops appears to have increased, and banks reported high returns on their

\footnotetext{
19 For a discussion, see Stiansen 1998, 67 including footnote 14.

20 Perhaps contrary to what could be expected, the prohibition of riba is generally not understood to mean that banks cannot charge more in cases of deferred payment, and hence the law recognises a time value for money.

21 Bank of Sudan, Statistics Department, June 2000.

22 An argument in favour of this view can be found in Khan 1994; see also Ali 1990; see also Khaleefa and Ibrahim s.a.
} 
investments. ${ }^{23}$ That high profit margins only benefited the banks caused resentment among farmers. To reduce tensions, the Bank of Sudan proposed that salam contracts should include a kind of PLS clause (called izalätal-ghubn, the removal of injustice), which effectively would limit a bank's profit to not more than one third of the salam price. ${ }^{24}$ The introduction of the clause was motivated by references to general Islamic principles and opinions of legalreligious scholars. Only government owned banks included this PLS clause, and in any case it did not have much impact because of a change in economic conditions.

Towards the end of the decade Sudanese agriculture entered a period of crisis and farmers began to default in large numbers. As a consequence banks suffered heavy losses, and some lost more than 50 per cent of their investments in agriculture. Farmers who were unable to meet their obligations were taken to court and thousands ended up in jail. Others left their land or tenancies. The scale of the repercussions caused deep resentment in affected rural communities. Because of their negative experience, farmers compared salam (and to a lesser extent other Islamic contracts) unfavourably with both conventional interest loans and traditional shayl finance. Many bankers shared these sentiments. Bank of Sudan statistics reflect the widespread misgivings. In 1992, the year after the contract had been introduced, salam contracts accounted for one half of total investments in agriculture, and around one fifth of the total volume of all formal investments in the different sectors of the economy. By the end of the decade, salam finance made up one fifth of formal investments in agriculture, and its relative share of total finance to all sectors had fallen sharply to one twentieth or 5 per cent. ${ }^{25}$

To conclude this section, the question can be asked whether or not the introduction of Islamic legislation led to substantial changes in the financial sector. The answer must be a qualified no. For instance, after 1983 banks were slow to change their lending policies, and when the government became more diligent in forcing the merchant community to use Islamic methods of finance the banks responded by offering "loans" disguised as murābaha contracts. While such contracts may have conformed to the letter of the law, they did certainly not conform to its spirit since banks as a rule took measures to reduce the element of real risk to a minimum, and profit margins were calculated on the same basis as interest. The emphasis on murābaha contracts continued the practice of short-term lending for import/export trade that has

23 Elhiraika 1996, 390-402.

24 Briefly stated, the central bank's proposal had two elements. 1 . If the sale price $(x 1)$ of the produce bought with a salam contract ended up being more than the salam price plus one third $(x 1+33.3 \%=y 1)$, the difference (i.e. $y 1-x 1)$ should be paid by the purchaser to the farmer. 2. If the sale price $(\mathrm{x} 2)$ was less than the salam price minus one third $(\mathrm{x} 2-33 \%=\mathrm{y} 2)$, the farmer should return the difference $(x 2-y 2)$ to the purchaser. For more details, see Kevane and Stiansen [forthcoming].

25 Bank of Sudan, Annual Reports 1992-1999, Bank of Sudan Statistics Department, June 2000. (The Annual Reports do not always break down the figures for the relative share of the different contract forms in the various sectors of the economy, but the general trend is quite clear.) 
dominated the Sudanese financial sector since the introduction of private commercial banks in the Condominium period (1898-1956). At the same time, it is clear that the present government's determination to change the system is having an impact. During the 1990s, the share of muräbaha finance has fallen from more than two thirds of the total volume of finance at the beginning of the decade to less than one half at the end. ${ }^{26}$ Remarkably in the figures from June 2000 the relative shares for murābaha and mushäraka contracts are roughly the same, around 35 per cent of the total. ${ }^{27}$ Even though there is some uncertainty connected with these figures ("other contracts" accounted for 10 per cent in 1998 and 1999, and 24 per cent in June 2000), ${ }^{28}$ this does indicate a willingness by banks to form partnerships with merchants, and if the trend continues it will mean a major shift towards long-term equity finance as opposed to short-term trade finance.

\section{II}

\section{Non-Muslims in Islamic Societies to ca. 1900}

Islam recognises and protects religious minorities. In some ways, it can even be argued that religious minorities have been indispensable to Muslim societies since traditionally they carried out roles and functions that the Muslims-by law or convention-avoided. Examples are the Armenian and Jewish moneylenders in the Ottoman Empire, the Coptic accountants in Egypt, and the so-called Levantine traders in contemporary Islamic West Africa. The riverain Sudan in the 19th century was no exception. Copts held key offices in the Egyptian administration and foreign entrepreneurs imported wine and spirits from Europe-one enterprising German even set up a distillery in Khartoum.

In classical times non-Muslims obtained permission to stay in Dār alIslām through a pledge of security $(a m \bar{a} n)$ or by virtue of treaty $(\text { dhimma })^{29}$ Amāns were of two kinds. The Imām of the community issued an official amān to non-Muslims as part of peace treaties or truces. A pledge of this kind lasted for no more than one year, and a musta min (the benefactor of the amān) had to pay an agreed amount in exchange for living without fear of harassment. Any Muslim adult could give an unofficial $a m \bar{a} n$ to a non-Muslim, and there was no set procedure to follow. Amāns might be withdrawn if the beneficiary did anything the ruler considered as "harmful to the interest of Islam". Musta mins were not permitted to conduct business practices prohibited by

\footnotetext{
${ }^{26}$ Bank of Sudan, Annual Reports 1992-1999.

27 Bank of Sudan, Statistics Department, June 2000.

28 As indicated, muqāwalas are not very different from murābahas, and the official figures do not list such contracts in a special category. It is therefore quite possible that bankers and others have again made a superficial change in order to comply with government policy.

${ }^{29}$ Khadduri 1955, 361.
} 
Islam, such as trading liquor or pork. Similarly they could not, at least officially, lend money at interest (usury contracts). Khadduri writes "the nonMuslim who entered the world of Islam without an amann, or was unable to secure one, [...] was killed unless he adopted Islam." Whether actual practice was equally severe is another question, and the same author concedes that the Shāfici school "permitted" a musta amin "a period of four months to leave the Islamic State, pay the jizya as a dhimmī, or adopt Islam". ${ }^{30}$

Dhimma treaties (a benefactor of such a contract is a dhimmin) regulated the position of permanent non-Muslim communities in Islamic societies until the legal reforms of the nineteenth century began to take effect. ${ }^{31}$ Through the dhimma, the Muslim community extended hospitality and protection to nonMuslim communities which enjoyed considerable autonomy since each had its own laws and its own leaders. Implied in the dhimma contract, however, was acknowledgement of the supremacy of the Muslim community and its leaders, and non-Muslims had to pay a distinguishing poll-tax (jizya) in addition to the land tax (kharāj). It can be assumed that dhimma contracts gave minorities the right to regulate commercial relations according to their own laws, but there is little evidence to suggest that there were distinct differences between the applied commercial law of Muslims and that of non-Muslims. ${ }^{32}$ In cases involving Muslims and non-Muslims, the standard procedure would have been to follow Islamic commercial law, but for the reason just stated this cannot have been seen as a great injustice by the non-Muslim party. The principles underpinning the commercial law of other religious communities were often compatible with those of Islamic law, and in any case local courts were quite pragmatic in cases dealing with commercial matters.

The Ottoman capitulations gave the subjects of European states residing in the Empire the right to follow their own laws, and commercial disputes involving foreigners were settled in consular courts. Because of their close links to expatriate communities, many members of the elites of the indigenous non-Muslim communities acquired European citizenship and thus came under the protection of the capitulations. While traditional Ottoman legal practice differed from contemporary European law, it was by no means a static legal system and fundamental features of modern economies, such as taking of interest, were not prohibited but regulated through the imposition of maximum rates. Legal reform formed part of the comprehensive tanzimat reforms, and the new commercial code adopted in 1840 (implemented in 1850) was to a large extent copied from French commercial law. By being secular, the new law would apply to Muslims and non-Muslims alike, and it was

\footnotetext{
${ }^{30}$ Khadduri 1955, 362.

${ }^{31}$ For a short essay on the legal status for the dhimma community, and practical implications for dhimmis, see "Dhimma", Encyclopaedia of Islam II, 227; for a longer and more negative examination, see Ye'or 1985. Strictly speaking, only members of other revealed religions (i.e. Christianity and Judaism) could benefit from such contracts, but as Islam expanded it became common to extend similar treatment to other religious groups even though they were not "of the book" (ahl al-kitāb).

32 See Al-Qattan 1999, 429-44.
} 
administered in mixed courts by Ottoman and European judges according to European legal procedure. ${ }^{33}$ The strength of the millet system, which to some extent was held up by European powers through their protection of religious minorities, prevented the legal reforms from taking full effect, and it was only the establishment of Ataturk's Turkish republic that realised the aim of a single legal system for all citizens in the former Empire.

With regard to the two most important sultanates of pre-colonial Sudan, Sinnār and Darfur, ${ }^{34}$ it is important to note that nowhere was the sharia applied in its entirety. In Darfur, traditional Fūr legal custom co-existed with the sharia, and in important respects, such as land tenure and rights of inheritance for women, local custom prevailed over the sharia. In Sinnār, the prominence of the sharia increased in the seventeenth and eighteenth centuries, and the move towards Islamic orthodoxy reflected the ascendancy of a new urban bourgeoisie which claimed Arab descent. Possibly Islamic laws were applied more stringently in enclaves (religious or commercial) where Muslim foreigners, or people who claimed foreign ancestry, lived in relative isolation. ${ }^{35}$ Before the nineteenth century, very few non-Muslims came to the Sudan (present borders) from Egypt, the Red Sea littoral and Ethiopia, and in any case among foreign Muslims observance of Islamic laws cannot have provoked objections of a principal nature. However, it is important to remember that immigration from the west and south in absolute numbers dwarfed immigration from the north and east. The majority of the people coming from the west would have been Muslims performing the hajj. The pilgrimage was definitely not the motivating factor for people coming from the south; and as enslaved they were subject to the sharia and the judgement of their masters.

A ruling from Darfur from 1863 gives some insight into how free nonMuslims fitted into the legal system of pre-colonial Sudan. The case concerns

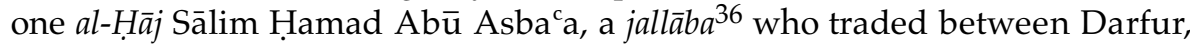
the Nile Valley and Upper Egypt and Āb Masịh the son of khawāja Shinūda alJawharī, an Egyptian Copt. The most important details are stated in the document as follows:

[al-Hāij Sālim Hamad Abū Asbaca] had taken from the khawāja Shinūda al-Jawharī three hundred and twenty mahb $\bar{u} b$ and gave him a tamassuk [i.e. a note] for this in the district of Dongola. And he promised to repay it after his return from Dār Fūr. But before his departure from the city of Siyut he repaid the aforesaid money in the

\footnotetext{
33 Yapp 1987, 112.

34 The Egyptian conquest of the northern riverain Sudan (including Kordofan) in 1820-1821 brought an end to Sinnār, and Darfur remained independent until 1874 when it was conquered by the forces of al-Zubayr Pasha, ostensibly in the name of the Egyptian Khedive.

35 O'Fahey 1980, 110; O'Fahey 1995, 34-35; O'Fahey 1994; O'Fahey and Spaulding 1972, 78-88; Spaulding 1977, 407-26. For a general study of the judicial system of pre-colonial Sudan, see alMuftī 1959.

36 The term "jallāba" (sing. jallāb or jallābī, pl. jallāba), from the verb jalaba "to bring", was first used for the leaders of the caravans trading between the Sudan and Egypt, but, in the nineteenth century, it became synonymous with "trader".
} 
presence of some people. The $m u^{c}$ allim Shinūda claimed that he had mislaid the shaqq

[i.e. the note] and promised that he would tear it up when he found it.

The note was not lost but resurfaced in the hands of Shinūda's son at the same time as a consignment of goods owned by al-Hāj Sālim arrived in the Nile Valley with a group of jallāba from Darfur. On the strength of the note, $\overline{\mathrm{A}} \mathrm{b}$ Masịh claimed some of al-Hāaj Sālim's goods equal to the value of the note. The jallāba in charge of the goods must have protested vigorously because $\overline{\mathrm{A}} \mathrm{b}$ Masīh sent an emissary to Darfur to ascertain whether or not the money had been repaid. In Darfur, Sālim produced three legally competent witnesses who testified that, indeed, he had repaid the full amount. The presiding judge (in the document called imām), Aḥmad wad Țāha, accepted their testimonies, and Shinūda's son was ordered to return the goods in question. The judgement was witnessed by twelve men, all of whom are named in the transcript. $^{37}$

It seems both parties accepted that their dispute would be resolved according to commercial law as understood in Darfur, and internal evidence in the ruling suggests that court procedure followed conventions of Islamic law. The ruling does not say what measures the court would take if $\bar{A} b$ Masīh failed to abide by its ruling, and it is difficult to see how the judge could have any authority outside Darfur. But as mentioned it is unlikely that he would refuse to accept the verdict, and therefore the case resembles binding arbitration between two parties who together had chosen the arbitrator (hakam). A Muslim represented Āb Masin in court, and the fact that the two parties to the case belonged to different religions does not seem to have been an issue. Yet, it is striking that all of the witnesses were Muslims. This may indicate that only Muslims could testify in a case involving a Muslim, but of course the explanation may simply be that no non-Muslims were available to testify.

Even though formally part of the Ottoman Empire after the Egyptian conquest in 1820,38 it is unclear to what extent the legal reforms of the tanzimat period were applied in the (Egyptian) Sudan during the nineteenth century. Certainly there were no organised mixed courts, but the Turkiyya (1820-1885) was not without legal reforms. The colonial government educated a number of Sudanese religious scholars at al-Azhar in Cairo, and they manned new sharia courts that initially heard both civil and criminal cases. Yet these legal reforms failed to have much impact. At the end of the period, the sharia courts were relegated to deal with cases relating to personal status and inheritance, while "through a system of local councils (majalis mahalliyya) set up in 1850, general civil and criminal jurisdiction devolved on amateur benches of notables and

37 Bjørkelo 1983, 305-06; an English translation of the transcript, which has been used here in a slightly modified form, is found on pp. 250-51. The document was photographed by Terenze Walz, and has also been discussed by R. S. O’Fahey $(1980,142-43)$. Of course, Darfur was still an independent state in 1863.

38 See Stiansen 1993. 
merchants applying customary law." ${ }^{39}$ In any case the government's sharia courts were restricted to a limited number of urban centres. There are very few known cases of consuls in Khartoum using their right under the capitulations to settle disputes between Europeans. Some consuls and representatives of the Roman Catholic mission intervened with the government to protect slaves.

Non-Muslims lost their formal privileges during the Mahdiyya (18851898). Not only did the last vestiges of consular protection evaporate with the fall of Khartoum, members of the foreign community were given the choice between conversion to Islam or death by execution. Almost all opted for conversion (if only superficially) and survived. Yet from a legal point of view, foreigners no longer constituted a distinct community but were subject to the same laws as those who by free will or birth were Muslims.

\section{Colonial Law}

The Anglo-Egyptian conquest of the Mahdist state introduced sweeping judicial reforms, and the new legal system drew on precedence from British colonies with Muslim majorities. First and foremost, the government introduced secular territorial legislation and all inhabitants became subject to the same criminal and civil laws. Matters not covered by written laws were to be decided by the courts according to "justice, equity and good conscience." 40 There was, however, one important exception to this principle since laws governing personal status were not formulated by the state. The Civil Justice Ordinance of 1900 (Section 3), the essence of which was repeated in all relevant subsequent legislation to 1983, set out the system:

Where in any suit or other proceedings in a civil court any question arises regarding succession, inheritance, legacies, gifts, marriages, divorce, family relations or the constitution of [waqfs] the rule of decision shall be:

(a) any custom applicable to the parties concerned which is not contrary to justice, equity and good conscience and has not been by this or any other enactment altered or abolished or has not been declared void by the decision of a competent court. 41

The law did not define "custom", but the meaning was clear enough. Muslims became subject to the sharia, and a combination of creed and/or place of residence decided the personal law of non-Muslims.

The "Mohammedan Law Courts Ordinance 1902" gave the sharia courts jurisdiction over:

39 Holt, 1968, 407-408

40 Mustafa 1970.

41 Tier 1995, 6A.100.28. While this survey does not really cover all developments during the last fifteen years, it remains the best general introduction to the legal system of the Sudan. The subsequent pieces of legislation are the Civil Justice Ordinance (1929), the Civil Procedure Act (1974) and the Civil Procedure Act (1983). 
(a) any question regarding matrimonial relations provided that the marriage was concluded in accordance with Mohammedan law and the parties are all Mohammedan,

(b) any question regarding donations inter vivos and testate and intestate succession between Mohammedans. 42

The situation was slightly different for non-Muslims since they could either subject themselves to the "laws" of their religious community, or the "local law and custom" of their ethnic group. Specifically in the southern Sudan nonMuslim "Africans" could choose between following the laws of their own ethnic group and canon law if they were Christians. In addition, non-Muslims could take their cases to civil courts for judgement according to the prevalent secular law; or they could subject themselves to sharia courts which would rule according to Islamic law. The latter alternative was more theoretical than practical. $^{43}$

The Civil Justice Ordinance created two divisions in the administration of civil law: the civil courts and the sharia courts. While the sharia division did not obtain full independence and equality before 1966, in actual fact sharia courts always "enjoyed complete independence in the exercise of their judicial functions", 44 and the Grand Qadi could in his own name issue rules and regulations. The Chief Justice did not try, even though he had the right to, whether rulings of sharia courts conformed with perceptions of "equity, justice and good faith". This was not the case in courts where cases were decided by "local law and custom". It is an interesting fact of Sudanese legal history that most cases have been brought before local courts and therefore tried before judges without formal legal training. ${ }^{45}$

The Anglo-Indian commercial code served as model for the commercial law, but subsequently the Condominium government borrowed new statutes, such as the Securities Act, directly from England. Officials were aware that some practices protected by the law-the taking of interest is the best example-were frowned upon by many Muslims. This led some government institutions to take precautionary measures. For instance, all depositors of the Post Office Savings Bank were obliged to sign a statement giving the bank permission to (a) "employ the funds deposited in any manner permitted by Sharia law outside of all nature of usury"; (b) "join in a lump sum the funds paid in by the depositor with those paid in by other depositors"; and (c) the account holder had the right to refuse to accept "a dividend proportional to the amount of his deposits". ${ }^{46}$ There is no evidence to suggest that any other financial institution went to similar lengths to avoid controversy; probably

\footnotetext{
42 Quoted from Khalil 1971, 628.

43 Tier 1990, 614.

44 Khalil 1971, 630.

45 Tier 1992, 201; Tier 1995, 6A.100.45.

46 The Post Office Savings Bank Regulations, Paragraph 7. The POSB was modelled on the post office saving bank in the UK.
} 
there was no need as people uncomfortable with interest payments stayed away from the modern banks.

Neither the importance nor impact of the legal reforms of the Condominium administration should be over-estimated. The point has already been made that most cases were settled in local courts and according to the conventions of the people concerned. This meant continuity of legal practice rather than change and innovation. Moreover, the division between state law and personal law remained much as before since traditionally the sharia did not apply in full in criminal cases. The one area where the Condominium government made a big difference, was the institutionalisation of Islamic law: the national legal code defined the competence of the Islamic law, the University of Khartoum (and later other universities) provided the education of future $q \bar{a} d \bar{i} s$, and the state paid for the legal hierarchy as well as the running costs of the courts.

\section{Islamisation to 1983}

The judicial system of the Sudan survived the transfer of power to the independent state with few changes. Independence did, however, bring to the fore conflicts which had been kept under the carpet during the Condominium. The nature of the constitution became one of the most contested issues. The Transitional Constitution, adopted 1st January 1956 (Independence Day), formalised a Westminster style of government, but it was (as the name indicated) never meant to be more than temporary. The debate on the new permanent constitution took many forms. In a long memorandum, Shaykh Hasan Muddathir, the Grand Qadi of the Sudan (i.e. the head of the sharia division of the judiciary), presented the Islamist position:

\footnotetext{
The intention of a People's constitution is to lay down general principles derived from the practical life of such people, and to devise laws from these principles for the protection of rules which the individuals have been obliged to follow in accordance with a recognized system prevailing upon their community.

This recognized system is the outcome of inherited beliefs, inborn customs and of what has been considered as good or bad by practice and modified by religion.

In an Islamic country like the Sudan the social organization of which has been built upon Arab customs and Islamic ways and of which the majority are Moslems, it is essential that the general principles of Islam, and, consequently, the laws governing its people should be enacted from the principles of an Islamic constitution and in accordance with Islamic ideals out of which such community has been shaped.

It is regretted that some of the present laws are, in most cases, inappropriate and contrary to Islamic legislations and even to the general principles of Islam. These laws instead of protecting the people's inherited beliefs and customs have tended to defeat the same. In fact they were laid down by colonists with a view of defeating the people's inherited creeds and sentiments. ${ }^{47}$
}

\footnotetext{
47 Shaykh Hasan Muddathir, issued "A Memorandum for the Enactment of a Sudan (sic) Constitution from the Principles of Islam", 1956, p. 1, quoted from Tier 1982, 145-46.
} 
While there is no space in this paper for a detailed analysis of this text, a few points should be made. First, the shaykh puts forward a majority rights' argument, and he conceptualises the future Islamic constitution, with subsidiary legislation, as a territorial law. Second, the secular legislation already in place is seen as a danger to the Islamic community. Third, the legal sources for the new constitution, however vaguely defined, are not limited to the Qur'ān and the sunna, or the sharia, but can include "good" customs as well. Fourth, the Islamic constitution should be the yardstick against which all other laws should be measured. Finally, the memorandum does not include guidelines for the legal methodology that would be required if the classical law and custom were to be reformulated as a modern constitution.

The government responded to the popular debate by establishing a Constitutional Committee. The work of this committee reflected the call for "immediate and total Islamisation", as expressed in Shaykh Hasan's memorandum, but it did not produce a draft constitution before the military took power in $1958{ }^{48}$ Immediately the Transitional Constitution was suspended, and General Abboud's regime ruled on the basis of a series of constitutional orders, the most important of which "established the Supreme Council of the Armed Forces as the highest constitutional, legislative, executive and judicial authority in the Sudan." 49 The military regime was not, however, neutral in the debate on the identity of the state, but promoted Arabism and Islamism to the detriment of other identities. In the southern, largely non-Muslim parts of the country, a government decree replaced Sundays with Fridays as the official day of rest, and Arabic replaced English as the medium of instruction in secondary schools. The expulsion of several hundred (foreign) missionaries represented a different expression of the same overall policy. ${ }^{50}$

Street demonstrations with mass-support forced the military regime to abdicate, and the civilian politicians restored the Transitional Constitution in a slightly amended form. After elections, the government set up a new constitutional committee with the same mandate as its predecessor. Again whether or not the Sudan should have an Islamic constitution, and the process of Islamisation, dominated the debate. Particularly the Muslim Brothers, now led by Hasan al-Turābī, pushed for immediate and total Islamisation, but the larger parties in the North, the National Unionist Party (NUP) and the two factions of the Umma Party, shared the same objective, even if they appeared less radical.

The move towards an Islamic constitution met strong resistance from politicians from the southern Sudan. At first, the Constitutional Committee did not include members from the main southern parties, probably because they had refused to participate in the elections, but those who eventually joined proposed a (secular) parliamentary republic as the system of government.

\footnotetext{
48 An-Naim 1985, 333.

49 Tier 1995, 6A.100.9.

50 Niblock 1987, 224.
} 
When it became clear they had no impact on the proceedings, the Southerners decided to boycott the committee's work. ${ }^{51}$

The Constitutional Committee presented the draft constitution in January 1968. Two articles marked the break with the secular tradition of the Transitional Constitution; they read:

\begin{abstract}
Any provision contained in any legislation, passed after the coming into effect of this constitution, which is repugnant to the principles laid down in the Kuran and Sunna, shall be void unless such repugnancy did exist before the coming into effect of this constitution. (Article 113)

The State shall promulgate the necessary legislation to amend all the laws which are repugnant to any principle in the Kuran or the Sunna and shall give effect to all the Sharia rules not now in force. Provided that the promulgation of such legislation shall be phased out in the manner which the Legislator deems necessary. (Article 114) ${ }^{52}$
\end{abstract}

Some comments are in order. While there could be no doubt as to the direction of the proposed legal reform, the draft constitution fell short of "immediate and total Islamisation" since both the phasing out of non-Islamic laws, and the introduction of Islamic laws, would be gradual. The most radical element, the proposal which gave all sharia rules legal force, would have little direct effect as long as appropriate legislation was lacking. In any case, the new constitution was still pending before parliament when the military again took power in a coup.

The new government, led by then Colonel Ja ${ }^{c}$ afar Nimayrī, abrogated the Transitional Constitution (1964), and Republican Order No. 1 vested executive and legislative functions with the Revolutionary Command Council and the Council of Ministers. Legal reform constituted an important part of the regime's agenda. The early phase of Nimayrī's rule is remembered for its economic and political radicalism, but the new Civil Code of October 1971 pointed in a different direction. While radical, in important respects it incorporated elements of the proposed Islamic constitution (1968) since courts were instructed to decide in accordance with the sharia in cases where there were no applicable provisions in the laws. (For good measure, the Code also said that the courts should be guided by the socialist principles of the government.)

\footnotetext{
51 Wenyin 1987, 20; Alier 1973.

52 Quoted from Mustafa 1970, 242. Zaki Mustafa's comprehensive survey of common law in the Sudan is also interesting as a pièce de circonstance from the late 1960s, early 1970s. Referring to an article where G.A. Lutfi, a member of the Supreme Civil Court, had written (in 1967) "English law will no doubt continue as the main guidance for our future legal development", he commented "Lutfi in his final conclusion [may have been] carried a little too far by his enthusiasm in defending English law," and added "[i]n fairness to him, however, one should stress the fact that he advocates the adaptation of the rules of English law to suit local needs and conditions and he bases this on the ground that those rules had already been tried and are therefore much easier to adapt than any others. This view is, without any doubt, the view of almost all Sudanese judges on the Bench, who continue up to this moment to apply rues of English law in preference to both rules of Islamic law and Egyptian law" (p. 237). Given later events, these statements by two legal authorities are quite remarkable for their lack of predictive power. The article by Lutfi referred to by Zaki is "The Future of the English Law in the Sudan", Sudan Law Journal Review, 1967.
} 
This made the sharia the "locus standi in the corpus juris of the Sudan," 53 and it marked a major new departure because the sharia obtained competence outside the personal law of Muslims. ${ }^{54}$ Previously, issues not covered by enacted laws-according to Muhammad Khalill, the doyen of Sudanese legal scholars-" "the greater part of the day-to-day business of courts" was "filled in by the application of English common law." The authority for this practice had been Section 9 of the (now repealed) Civil Justice Ordinance which said "in cases not governed by any enactment for the time being in force, the court shall decide according to what it considers to be in conformity with justice, equity and good conscience." 55 In a comparative context, this Code belonged to the French legal tradition and was similar to corresponding codes in Egypt and Syria - the Code had even been prepared by Egyptian and Syrian jurists.

In reality the Civil Code of 1971 had little relevance. Binding precedence remained a fundamental feature of legal practice in the Sudan, and in any case the Organisation of Laws Act of 1973 repealed the Code. Section 7 of the new Act "required the civil courts to decide, in the absence of legislation, according to the principles" established in "Sudanese judicial decisions, the principles of Sharia law, custom and good conscience." This closely resembled Section 4 of the Civil Code, but the sources of law were no longer ordered in a hierarchy. For more than two decades there were no reported cases of civil courts extending the sharia to decide cases not covered by existing legislation. ${ }^{56}$

The (permanent) Constitution of 1973 continued the trend toward closer alignment between actual legislation and Islamic values. Sharia and custom were mentioned as the main sources of legislation, but this did not imply a surrender to the Islamist position. Article 16 made this quite clear:

(a) In the Democratic Republic of the Sudan Islam is the religion and the society shall be guided by Islam being the religion of the majority of its people and the State shall endeavour to express its values.

(b) Christianity is the religion in the Democratic Republic of the Sudan, being professed by a large number of its citizens who are guided by Christianity and the State shall endeavour to express its values. .7

At least superficially this established two state religions, Islam and Christianity. All followers of "religions and spiritual beliefs" were promised equal

\footnotetext{
53 Khalil 1971, 624-25.

54 Strictly speaking this is not quite correct since as indicated above non-Muslims in matters of personal status could subject themselves to a sharia court, and in 1961 the Sudan Mohammedan Law Courts Act (Amendment) extended the competence of sharia courts to matrimonial cases where the female party to the conflict was "kitābiyya", i.e. a believer in one of the Holy Books. The Sharia Courts Act (1967) took this one step further by stating that the sharia courts were competent to hear matrimonial cases if one of the parties, not necessarily the women, believed in one of the Holy Books.

55 Khalil 1971, 624. Emphasis added.

56 Tier 1992, 205-06.

57 Quoted from Tier 1982, 147.
} 
treatment, and non-Muslims would continue to be governed by their own personal laws. Yet the constitution left important questions unresolved. To give but two examples. First, would Islam or Christianity prevail in cases where reasonable interpretations of both systems of thought produced conflicting legal positions? Second, to what extent could there be room for conflicting legislation outside the spheres of personal laws? The potential for conflict was real since the Regional Self-Government Act of 1972, incorporated in the constitution as an "organic law", gave the southern regional assembly the right to enact general legislation including laws in the "economic field", and even the Act itself took into account that laws promulgated by the National Assembly in Khartoum might be seen by people in the South as adversely affecting their "welfare and interests". 58

Several coup attempts led Nimayrī to broaden his support base through a process of national reconciliation. Commencing in 1977, this brought leading members of the religious parties back into government, and represented a definitive break with ideas that initially had prompted the May Revolution. The establishment of a "Committee to Revise the Laws of the Sudan so as to Conform with the Sharia Rules and Principles" gave new vigour to the Islamisation debate. Chaired by Hasan al-Turābī, the committee drafted six bills and produced a long list of laws and provisions it considered against Islamic teachings. The government only enacted one of the six bills, the zakāt bill; yet aspects of the un-enacted bills are directly relevant in the present context

The Consumer and Co-operative Bill proposed the prohibition of interest on consumer and co-operative loans. Obviously, this was motivated by the prohibition of riba, but the bill had the appearance of a compromise since banks were exempted. This lack of consistency may have been the result of a pragmatic concern for the Sudan's relations with the international community. ${ }^{59}$ The proposed Sources of Judicial Decisions Bill required legislative provisions to be in accordance with the sharia, "unless such provisions [were] already interpreted or [had] been given a definitive meaning." 60 This meant that the sharia would apply in cases where there was an absence of established legal practice. If such cases surfaced, the bill proposed that the courts should apply analogy or consensus, the classic methodology of Islamic law, to reach decisions. Due regard for the common good, another key feature of classic Islamic jurisprudence, was also given emphasis. Remarkably, the Sources of Judicial Decisions Bill did not propose that the sharia should apply in criminal cases, but a separate bill addressed the implementation of $h u d \bar{u} d$ punishments for murder, theft, adultery, etc. The position of non-Muslims, with regard to laws, was dealt with by proposing a combination of exemptions

58 Law for Regional Self-Government in the Southern Provinces (February 1972), Articles 11 and 14. The full text of the law has been reproduced in several places including in Wöndu and Lesch 2000, 195-213.

59 Tier 1982, 149.

60 Tier 1982, 149. The bill is called Judgements (Basic Rules) Bill. 
on a territorial and non-territorial basis. In the case of the former, the exemption applied to provinces in the southern Sudan, and in the case of the latter the exemption was decided by religious or ethnic identity. ${ }^{61}$

\section{Nimayrī's Islamic Revolution}

The legal revolution of 1983-1984 is of seminal importance in the Sudan's post-independence history. Not only did new acts and regulations replace most of the legislation in place, the Sources of Judicial Decisions Act (1983) went beyond all previous proposals aimed at Islamisation since courts were required to "apply Sharia law as established by the Koran and Sunna, not only in the absence of legislation but also notwithstanding any legislative provision in another law." 62 This extended the competence of the sharia to all areas of the law, and the Islamic laws were territorial since they applied throughout the whole country. Nimayrī's revolution fell short of giving the country an Islamic constitution, and the Permanent Constitution remained in force. Yet de facto the Sudan became an Islamic state, and from this perspective it made sense for the President to call himself al-Imām, the leader of the community of believers.

Aspects of the revolution seem quite incredible. While the Sudanese Socialist Party, the sole legal political organisation, had unanimously endorsed the President's "Islamic Path", the laws were prepared by three inexperienced lawyers, and enacted through a Provisional Republican Order which was confirmed by the People's Assembly after very little debate. Neither the Attorney General, Hasan al-Turābī, nor his office were involved in the drafting of the laws, even though the acts in part were based on the work of al-Turābī's committee from the late 1970s; al-Turābī may even have had some personal influence over the committee members. ${ }^{63}$

The Islamic laws applied to all Sudanese alike. Shortly after the introduction of the September laws, President Nimayrī had sought to reassure members of religious minorities by stating: "We will not tolerate any violation of the non-Muslims' rights or any violation of their personal freedom or of the principles of justice and equity ...". ${ }^{64}$ Subsequently the government indicated that some provisions, such as the prohibition of alcohol, would not be enforced in the southern provinces. These efforts at soothing the concerns of nonMuslims had little effect. Repeal of the sharia laws became a key demand for the (mainly southern) Sudan People's Liberation Movement (SPLM), and a precondition for a negotiated settlement of the civil war. Even a stalwart member of the Muslim Brotherhood recognised how the implementation of

\footnotetext{
61 Tier 1982, 150.

62 Tier 1982, 208. Emphasis added.

63 Warburg 1990, 628.

${ }^{64}$ Quoted from Ronen 1999, 79.
} 
the sharia "implied an inferior status for all non-Muslims." 65 This perception is also found in critical studies by Muslim and non-Muslim Sudanese academics. ${ }^{66}$

A popular uprising brought down Nimayrī. Undoubtedly much of the public anger was directed against the excesses during his Islamic phase; it should be sufficient to mention the public outcry against the hanging of Mahmūd Muhammad Taha, and the loathing of the emergency courts (which excelled in applying the $h u d \bar{u} d$ punishments). Against this background, it is remarkable that neither the Transitional Government (presided over by the Chief of the Army) nor the democratically elected government, led by Prime Minister Șādiq al-Mahdī, seriously tried to reverse Nimayrī's revolution. Rather the former introduced an interim constitution that merely suspended some of the September Laws, and the latter sought to replace offensive laws with new laws. For instance, in September 1988 the government introduced a new Penal Code to replace the $h \bar{u} d u d$ Penal Code of 1983, but it was withdrawn after the second reading in Parliament. ${ }^{67}$ In the case of Șādiq, his inertia is food for thought because, in a major speech immediately after the introduction of the so-called September Laws, he had declared them unIslamic and therefore without legitimacy.

A debate regarding the regulating of the financial sector gives some insight into the dilemmas Șādiq faced when he at the same time sought to distance himself from the unpopular laws and defend Islamisation as such. Members of the merchant community as well as bankers wanted the government to legalise lending and borrowing with interest. In principle, the Prime Minister agreed, but he did not go as far as proposing to change the rib $\bar{a}$ legislation. Instead, as mentioned above, he allowed banks to charge compensatory rates on loans, and pay compensatory rates on deposits. But since the rates were calculated ex ante, they were nothing but interest rates by other names. The chairmen of sharia boards of the Islamic banks objected to what they considered a violation of the (Islamic) law, and sent a strongly worded protest to the Prime Minister. When defending himself, Șādiq again did not go to the heart of the matter, the prohibition of interest in the Civil Transaction Act (1983), but sought to rebut his critics by claiming to have a deeper understanding of the Qur'ānic prohibition of ribā.68

During the first half of 1989 several events gave evidence of how members of the public were becoming exasperated with Șādiq's dithering and the government's in general lacklustre performance, and the coup of 30th June 1989 did not come as a surprise. The new military junta gave several pragmatic reasons for taking power: to end the civil war, to fight corruption, to reduce the influence of the sectarian parties, and to defend the integrity of the

\footnotetext{
65 Warburg 1990, 331.

66 An-Na'im 1992, 289; idem. 1987; Tier 1982, 134; Safwat, 1989, 246.

67 Tier 1992, 209.

68 For a longer discussion, see Stiansen 1999, 108-12.
} 
Sudanese currency which was depreciating quite rapidly against the dollar. Yet there was never any doubt that the real motivation was fear that the government would reach a compromise with the SPLM which would jeopardise the Islamic nature of the state. Starting before the elections in March 1986, several groups and leading politicians from the northern Sudan had signed agreements with the SPLM which by implication threatened the survival of the sharia laws, and both the DUP and the Umma parties endorsed the idea of a national constitutional conference where the issue of religion and politics would be the main item on the agenda. Moreover, a committee working under the Prime Minister argued that non-Muslims were entitled to be exempted from the Islamic laws, and finally on the very day of the coup a committee constituting senior legal scholars and former politicians presented the government with a draft law which, if implemented, would abrogate the September laws. ${ }^{69}$

One of the first actions of the Islamist military regime was to suspend the 1985 interim constitution. Next followed much stricter enforcement of the September laws. The promulgation of the regime's own constitution, adopted in 1998, completed the drive toward comprehensive Islamisation. However, the constitution does not per se claim to be an Islamic Constitution, and parts are couched in quite general terms. Witness some articles in the section called "The Guiding Principles of the State":

Article 1

The State of Sudan is a country of racial and cultural harmony and religious tolerance. Islam is the religion of the majority of the population and Christianity and traditional religions have a large following.

Article 4

God, the creator of all people, is supreme over the State and sovereignty is delegated to the people of [the] Sudan by succession, to be practised as worship to God, performing his trust, developing the homeland, and spreading justice, freedom and shura [i.e. consultation] in accordance with the Constitution and laws.

Article 18

Those working for the state and those in public life should worship God in their daily lives, for Muslims this is through observing the Holy Qurān and the ways of the Prophet, and all people shall preserve the principles of religion and reflect this in their planning, laws, policies, and official work or duties in the fields of politics, economics, and social and cultural activities; with the end of striving towards the societal aim of justice and righteousness, and towards achieving the salvation of the kingdom of God.70

\footnotetext{
69 Wöndu and Lesch 2000, 11-12; Warburg 1990, 636-37.

70 Quoted according to one of the texts found on the internet: www.sudan. net/government / constitutioin/english.html. (Note that one "Authorised English Version", at www.sufo.demon. co.uk/ cons001.html, differs quite considerably from the text used here.) The Arabic original can be found at this site: www.sudan.net/government/ constitution/index1.html. The preamble of the Constitution reads: "In the name of God, the creator of man and people, the granter of life and freedom, and the guiding legislator of all society. We, the people of Sudan, with the help of God, cognisant of the lessons of history, and with the help of the revolution of National Salvation, have made this Constitution to establish a public order, which we undertake to respect and protect, so help us God."
} 
Yet other parts of "Guiding Principles" section, as well as several articles in subsequent sections, make the distinctly Islamic frame of reference clear enough. The Sources of Legislation provision (Article 65) says no legislation should contravene Islamic law, ${ }^{71}$ and citizens are instilled with such Muslim duties such as paying zakāt (Art. 10) and answering the call for jihad (Art. 35). ${ }^{72}$ Possibly Articles 18, 24, and 27 provide room for minorities to be governed by their own personal laws, and the occasional mentioning of obligations for Muslims only, such as abstinence from alcohol, can be interpreted along the same lines. But legal pluralism, even within a limited sphere of the civil law, is not addressed as a principle. The government has been careful not to enact the most brutal hudu $d$ punishments, even though they are kept on the statute books in the form of the Islamic Criminal Act of 1991.

The constitution sets the framework for the national economy, and Paragraph 8 is the most important section. It reads:

\begin{abstract}
The State directs the growth of the national economy [and is] guided by planning on

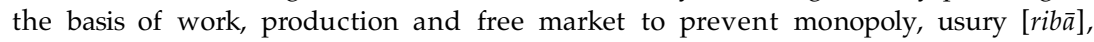
cheating, and to ensure national self-sufficiency, abundance, blessings and the aims of justice among states and regions.
\end{abstract}

The key word is riba, and it upholds the financial legislation that emanated from the original prohibition of interest in 1983. (Incidentally, the Civil Transactions Act (1983) does not use rib̄ but $f \bar{a}^{\top} i d a$ which is a word without religious connotations.) It follows that there is no freedom of contract, and all transactions-among Muslims as well as non-Muslims-must be in agreement with orthodox interpretations of Islamic law. In passing it can be mentioned that in the context of the constitution, it would have made much more sense to see riba as exploitation in general, and not interest or usury.

\title{
Conclusion
}

Islamic laws govern the Sudanese economy. Since the same laws apply to all, irrespective of personal confession or domicile, the logical conclusion to the question posed in the title of this article is that there is no room for nonMuslims in the Sudanese Islamic economy. Or put differently, Muslims and non-Muslims alike have to follow the same laws and these have been constructed to confirm with Islamic norms and regulations. There is neither room

\footnotetext{
71 The full paragraph reads: "The Islamic Sharia and the national consent through voting, the Constitution and custom are the source of law and no law shall be enacted contrary to these sources, or without taking into account the nation's public opinion, the efforts of the nation's scientists, intellectuals and leaders." Basically the same point is made in Article 139A, which reads: "Sharia, then consensus of the people expressed through a referendum, the Constitution and custom are the sources of law." The word "then", which is translated from the Arabic "thumma", indicates quite clearly a hierarchy in sources of legislation.

72 Regarding jihad, the relevant section in the Arabic text of the constitution reads: "al-difā ${ }^{c}{ }^{c} a n$ al-watan wa talbiyya nad $\bar{a}^{3}$ al-jihād wa-l-khidmat al-wataniyya"; curiously in the so-called authorised English version this is translated as "to defend the country and respond to the call for national defence and national service."
} 
for dhimmī communities, nor can anybody "opt out" in favour of secular laws. Of course, this answer to the question holds true only as long as it is answered with the constitution as reference point. Effectively this excludes most of the southern part of the country where non-Muslims form the majority.

The present situation is not without precedence, since it resembles the Mahdiyya when first the Mahdi and later the Khalifa sought to impose legal orthodoxy on all. But governments of the pre-colonial sultanates were more pragmatic; after his visit to the Sinnār in 1701, the Fransiscan priest Theodoro Krump (overlooking the fate of slaves) even wrote "this is a free city, and men of any nationality or faith may live in it without a single hindrance." 73 In important respects the Anglo-Egyptian administration of the early twentieth century re-established traditional legal practice (in Sinnār and Darfur) by limiting the competence of the orthodox sharia to certain areas of the law. The gradual widening of the competence of the sharia that followed Independence can be explained at two levels. First, as a reflection of the Muslim establishment's attempt to forge a link between their Islamic heritage and modern institutions, and second, as a determined strategy by the (Muslim) riverain establishment that inherited the colonial state to retain their hegemonic position by defining the state in their image. ${ }^{74}$ Either way, Islamisation through legal reform-the preferred strategy-was doomed to meet strong opposition because, unlike in the past, the non-Muslim minority demanded to be heard.

There is a remarkable consistency among proponents of Islamisation. The Grand Qadi's view on the (Islamic) constitution as expressed in the 1950s is repeated in the National Islamic Front's Sudan Charter from 1987, and the same sentiment runs through the Constitution of 1998. Another striking feature of the debate during the past half-century is the failure by advocates of Islamisation to appreciate why non-Muslim minorities oppose national legislation on the basis of the sharia. One example is Hasan al-Turābi's comment to a journalist in 1979:

\footnotetext{
The Christians have no special law. Christ advised them to follow the Roman Law, and there is no reason for them to feel offended if law [i.e. the judicial system] becomes Islamic. According to Islam, they would anyway be granted freedom of religion, or education, of propagation of the faith and even some local autonomy for non-religious affairs. But we don't want politics and economy to be separated from religion.75
}

Opposition to Islamic laws has been equally consistent. In the 1960s and 1970s, non-Muslim politicians challenged all attempts at Islamisation, and the Bor mutiny, which in 1983 started the second phase of the civil war, gained support because of popular resistance against Nimayrī's Islamic revolution.

\footnotetext{
73 Spaulding 1974. This is a translation of Theodoro Krump's Hoher und Fruchtbarer Palm-Baum des Heiligen Evangelij (Augsburg: Georg Schulter \& Martin Happach, 1710). 
The Sudan Peoples' Liberation Army fights for a new Sudan with a secular constitution, and the principle of separation of state and religion is adopted in the Asmara Declaration, the charter of the National Democratic Alliance. Remarkably both Muhammad Uthmān al-Mirghanī, the dominant force in the Khatmiyya sufi order, and Șādiq al-Mahdi, always aspiring to be the head of the religious as well as political manifestations of the Mahdist movement, signed this document when in exile.

Finding a lasting solution to the on-going civil war depends on resolving the question of the identity of the state. Recent efforts at initiating meaningful negotiations between the Government of the Sudan and the committed opposition have only served to re-enforce their entrenched positions. A vision of a secular Sudan confronts a vision of an Islamic Sudan. ${ }^{76}$ This does not leave much space for discussion, but the debate is not over. Three factors may lead to a softening of the Islamist position. First, the enactment of Islamic legislation has not solved any of the Sudan's fundamental problems, and the civil war is tearing the country apart. Second, there is no consensus on definitions of key Islamic concepts (witness the debate on rib $\bar{a}$ ), and the state's obedience to rigid definition has been accompanied by worsening living conditions for all but a small elite. Finally, the case for minorities' rights is strong also within the context of Islamic law. To have room for non-Muslims in the economy, in a legal sense too, will be in line with centuries of Islamic practice, and in the Sudan there is ample precedence for pragmatism.

\section{References}

Sources

Bank of Sudan, Annual Reports 1992-1999.

Bank of Sudan, Statistics Department, June 2000.

Newspaper

The Middle East, September 1979.

\section{Literature}

Ali, Ali Abdallah (1990). "How to Reach the Small Farmer? An Islamic Formula", IFDA Dossier, 75/76, January/ April, 35-44.

Alier, Abel (1973). "The Southern Sudan Question", in The Southern Sudan: The Problem of National Integration, Dunstan Wai (ed.), London.

Bjørkelo, A. (1983). “From King to Kāshif”. Dr. Philos.-thesis, University of Bergen.

Deng, Francis M. (1995). War of Visions: Conflict of Identities in the Sudan, Washington DC.

"Dhimma," Encyclopaedia of Islam II, 227-31.

76 Deng 1995. 
Elhiraika, Adam B. (1996). "Risk-Sharing and the Supply of Agricultural Credit: A Case Study of Islamic Finance in Sudan", Journal of Agricultural Economics, 47:3, 390-402.

Gordon, Carey N. (1985). "The Islamic Legal Revolution: The Case of Sudan”, The International Lawyer, 19: 3, 793-815.

Holt, P.M. (1968). "Modernization in Reaction in the Nineteenth-Century Sudan", in Beginnings of Modernization in the Middle East: The Nineteenth Century, William R. Polk and Richard L. Chambers (eds), Chicago, 401-415.

Hunwick, John (1999). "Islamic Financial Institutions: Theoretical Structures and Aspects of Their Application in Sub-Saharan Africa," in Credit, Currencies and Culture: African Financial Institutions in Historical Perspective, Endre Stiansen and Jane I. Guyer (eds), Uppsala, 72-99.

Kevane, Michael and Endre Stiansen [forthcoming]. “'Removal of Injustice': Market Logic versus Moral Economy in Islamist Sudan".

Khadduri, Majid (1955). "International Law", in Law in the Middle East, Vol. 1, “Origin and Development of Islamic Law", Khadduri, Majid and Herbert J. Liebesny (eds), Washington DC.

Khan, Mohsin S. and Abbas Mirakhor (eds) (1987). Theoretical Studies in Islamic Banking and Finance, Houston.

Khan, Muhammad Akram (1994). Rural Development through Islamic Banks, Leicester.

Khaleefa, Mohmmad Uthman and Salah Eddin Alshazali Ibrahim, (s.a.). "Sudanese Islamic Bank (SIB)" mimeo, Khartoum.

Khalil, M.I. (1971). "The Legal System of the Sudan", International and Comparative Law Quarterly, 20, October, 624-44.

Kuran, Timur (1986). “The Economic System in Contemporary Islamic Thought: Interpretation and Assessment", International Journal of Middle Eastern Studies, 18:1986, 135-64.

- (1997). "Islamic Economics: A Chapter in the Politics of Muslim Identity", Social Research, 64: 2, 301-38.

Al-Muftī, Husayn Sīd Aḥmad (1959). Taṭawwar nazām al-qaḍa $\bar{a}^{\jmath}$ fi-l-Sūdān, [Khartoum?].

Mustafa, Zaki (1970). The Common Law in the Sudan: An Account of the 'Justice, Equity and Good Conscience' Provision, Oxford.

An-Naim, Abdullahi Ahmad (1985). “The Elusive Islamic Constitution: The Sudanese Experience", Orient, Vol. 26: 3, 329-40.

- (1987). "Religious Minorities under Islamic Law and the Limits of Cultural Relativism", Human Rights Quarterly, 9, 1-18.

- (1992). "Civil Rights in the Islamic Constitutional Tradition: Shared Ideals and Divergent Regimes", The John Marshall Law Review, 25:2, 267-93.

Niblock, Tim (1987). Class and Power in Sudan: The Dynamics of Sudanese Politics, 1898-1985, London.

O'Fahey, R. S. (1980). State and Society in Dār Fūr, London.

- (1993). "Islamic Hegemonies in the Sudan: Sufism, Mahdism and Islamism," in Muslim Identity and Social Change in Sub-Saharan Africa, Louis Brenner (ed.), Bloomington, 21-35.

- (1994). "Fur Law [and] Sharia Courts: Judicial Compromise in the Darfur Sultanate." Paper presented to the Joseph Schacht conference on the theory and practice of Islamic law, Universities of Amsterdam and Leiden, 6-10 October 1994.

- (1995). "The Past in the Present? The Issue of the Sharia in Sudan," in Religion and Politics in East Africa: The Period since Independence, Holger Bernt Hansen and Michael Twaddle (eds), London, 32-44.

O'Fahey, R. S. and J.L. Spaulding (1972). Kingdoms of the Sudan, London.

Al-Qattan, Najwa (1999). "Dhimmīs in the Muslim Court: Legal Autonomy and Religious Discrimination", International Journal of Middle Eastern Studies, 31, 429-44.

Rahman, Fazlur (1964). "Riba and Interest", Islamic Studies, 3: 4, 1-43.

Ronen, Yehudit (1999). "Religion and Conflict in Sudan: A Non-Muslim Minority in a Muslim State", in Minorities and the State in the Arab World, Ofra Bengio and Gabriel Ben-Dor (eds), Boulder, 73-87.

Safwat, Safiya (1989). "Islamic Laws in the Sudan”, in Islamic Law: Social and Historical Contexts, Aziz al-Azmeh (ed.), London, 231-49.

Schacht, Joseph (1986 [1964]). An Introduction to Islamic Law, Oxford. 
Spaulding, Jay (1974). The Sudanese Travels of Theodoro Krump. (Available at www.kean.edu/ history/krump2home.html.)

Spaulding, J.L. (1977). "The Evolution of the Islamic Judiciary in Sinnar", The International Journal of African Historical Studies, 10, 3 (1977), 408-26.

Stiansen, Endre (1993). “Overture to Imperialism: European Trade and Economic Change in the Sudan in the Nineteenth Century". Dr. Philos. thesis, University of Bergen.

-(1998). "The Gum Arabic Trade in Kordofan," in Kordofan Invaded: Peripheral Incorporation and Sectoral Transformation in Islamic Africa, Endre Stiansen and Michael Kevane (eds), Leiden, 60-85.

-(1999). "Islamic Banking in the Sudan: The Laws and the Debate," in Credit, Currencies and Culture: African Financial Institutions in Historical Perspective, Endre Stiansen and Jane I. Guyer (eds), Uppsala, 100-117.

Tier, Akolda M. (1982). "Freedom of Religion under the Sudan Constitution and Laws", Journal of African Law, 26: 2, 133-51.

- (1990). "Conflict of Laws and Legal Pluralism in the Sudan", International and Comparative Law Quarterly, 39, July, 611-40.

- (1992). "Islamization of the Sudan Laws and Constitution: Its Allure and its Impracticability", Law and Politics in Africa, 25, 199-219.

- (1995). "The Legal System of the Sudan", Modern Legal Systems Cyclopedia, 6A.100.7-6A. 100.79 .

Udovitch, Abraham L. (1970). Partnership and Profit in Medieval Islam, Princeton.

Vogel, Frank E. and Samuel L. Hayes III (1998). Islamic Law and Finance: Religion, Risk, and Return, The Hague.

Warburg, Gabriel R. (1990). "The Sharia in Sudan: Implementation and Repercussions, 19831989", Middle East Journal, 44: 4, 624-37.

Wenyin, Deng Awur (1987). "Southern Sudan and the Making of a Permanent Constitution in Sudan". Paper, University of Juba.

Wöndu, Steven and Ann Lesch (2000). Battle for Peace in Sudan: An Analysis of the Abuja Conferences 1992-1993, Lanham.

Yapp, M. E. (1987). The Making of the Modern Near East 1792-1923, London.

Ye'or, Bat (1985). The Dhimmi: Jews and Christians under Islam, translated by David Maisel, Paul Fenton and David Littman, revised and enlarged English edition, Rutherford. 


\title{
CHAPTER III
}

\section{Sidi Fredj: A Case Study of a Religious Endowment in Morocco under the French Protectorate ${ }^{1}$}

\author{
Franz Kogelmann
}

The terms "social justice" and "social welfare" are usually used within the context of western industrial nations, ${ }^{2}$ while Muslim states are more frequently labelled "third world" or classified as "threshold countries". Morocco falls into this last category. The current constitution defines the Moroccan system of rule as a constitutional, democratic and social monarchy (article 1) and names Islam as the state religion (al-Islām din ad-dawla) (article 6). There is indeed some degree of social welfare in modern Morocco, although this is largely limited by the nation's circumstances. ${ }^{3}$ State-supported social welfare measures such as social and health insurance are restricted to the relatively small circles of state and public service employees, and employees in the "white" (i.e. official) economy. However, workers in agriculture and in the "black" (i.e. unofficial) economy, both of which are important economic factors, fall outside this system. ${ }^{4}$ As a result, the Kingdom of Morocco is quite far removed from the western idea of a welfare state, and this would appear to confirm the theory that there is a link between the degree of industrialisation and the development of a social welfare system. This theory asserts that the higher the degree of industrialisation, the more comprehensive the state social welfare. In reverse, this could mean that pre-industrial societies possess absolutely no social welfare system beyond a simple family-based one. ${ }^{5}$

If we are to believe contemporary reports, Morocco at the end of the nineteenth and at the beginning of the twentieth century was one of the most untouched and closed countries of the southern shore of the Mediterranean. ${ }^{6}$ The "Land of the Moors" was until 1912 still outside the direct colonial influence of the European powers, thus Morocco at this time was one of the most

\footnotetext{
1 This article is the revised form of a paper presented at the workshop "Social Justice, Social Welfare and Praxis in Islamic Societies in Africa", Helsinki, 23-23 April 1999. The research for this article was made possible by the Deutsche Forschungsgemeinschaft (DFG) between 1992 and 1997.

2 Pinker 1980, 223.

3 Ahmed 1988, 550-51.

4 See further Müller 1997.

5 On the praxis of charity in Europe before the welfare state, see Barry/Jones 1991.

6 See further Harris [1929] 1994; Michaux-Bellaire 1920; Cunninghame Graham [1898] 1988; Foucauld [1888] 1999; Meakin [1901] 1986; Zabel 1911.
} 
interesting places for travellers, adventurers and compradores. Supposedly, such basic inventions as the wheel played little or no role in nineteenth century Morocco, ${ }^{7}$ and the economy was characterised by extensive agriculture, traditional handicrafts and rudimentary international trade. ${ }^{8}$ The sphere of influence of the Sultan and his ruling apparatus was limited to a few towns and cities and their direct surroundings which rose up like islands from a sea of warring tribes. If we apply the theory quoted previously-regarding the direct connection between social welfare and degree of industrialisationto Morocco prior to the creation of the French protectorate in 1912, we must admit that the Sharifian empire demonstrates conditions particularly unfavourable to the creation of a welfare state.

These preliminary considerations lead us to a set of questions: Did Morocco have to wait to be 'blessed' with French civilisation and the resultant partial industrialisation before it could enjoy social welfare institutions? Is there really a direct causal link at all between industrialisation and social welfare in the case of Morocco? And does Moroccan society have a genuinely Islamic institution that has guaranteed at least a minimum of social justice and welfare?

I would like to claim here that even a pre-industrial Muslim state, such as Morocco was before the creation of the French protectorate, possessed religiously-motivated welfare institutions which went beyond the limitations of a simply traditional family-based welfare. I will try to ratify this claim using the development of Islamic pious endowments in Morocco as evidence. My particular point of reference is Sidi Fredj in Fez, the most important and most traditional endowment complex in Morocco, which has devoted itself exclusively to social welfare activities.

\section{The Concept of Waqf}

The giving of alms (zakāt or șadaqa) is one of the so-called five pillars of Islam (arkān ad-dīn). ${ }^{9}$ In this sense, caring for the weaker members of the community or involvement in the spreading and the consolidation of the faith are traditional signs of Islamic piety. Both Qur'ānic in their origins, șadaqa and zakät both mean a religiously virtuous giving of alms, but while șadaqa has come to mean a voluntary donation to help the needy, zakāt developed into a tax for the poor imposed by the state on all believers and which was "very precisely regulated in the formulation of the $\operatorname{shari}^{c} a^{\prime \prime} .{ }^{10}$ Even if the collecting of

\footnotetext{
${ }^{7}$ Laroui 1993, 41-42; Schroeter 1988, 99, 212.

8 On the different interpretations of the economy of Morocco before the French protectorate, see Mojuetan 1995, 77-105 as well as Miège 1962 and Schroeter 1988.

${ }^{9}$ On zakāt and șadaqa see Watt/Welch 1980, 299-306 as well as Weir, șadaqa in Encyclopaedia of Islam (new edition).

10 Watt/Welch 1980, 303, translation by the author.
} 
this tax proved inefficient and open to corruption in Islamic history ${ }^{11}$ and has become obsolete in most modern Muslim states, at the end of the twentieth century the zakät is an obligatory tax in Pakistan, Sudan, Libya and Saudi Arabia. In Jordan, Bahrain, Kuwait, Lebanon, Malaysia and Bangladesh the collection of zakāt is organised by the state and regulated by law, but the Islamic almsgiving is voluntary. ${ }^{12}$ In parts of the Muslim world the seminal thoughts of Sayyid Qutb-in his opinion zakat "is the distinctive social pillar of Islam" (ar-rukn al-ijtim̄a $\bar{a}^{c}$ al-bāriz min arkān al-islām $)^{13}$ and it is the "purification of the conscience and [...] of the wealth" (at-tahāra li di-damār wa [...] li $\left.i^{3} l-m \bar{a} l\right)^{14}$ were spread and there has been renewed discussion of the zakat recently, and opposition Islamists have placed this traditional Islamic tax high on their agendas with a view to fighting social injustice. ${ }^{15}$

Pious endowments gave this ideal of religiously-motivated charity a lasting institutional form. Islamic endowments are known in Arabic as waqf (plural awqāf) but in the Maghreb more commonly as hubs (plural ahbās), and-in Marshall Hodgson's words-had already taken over the role of a "vehicle for financing Islam as a society" 16 from zakāt in the first few hundred years of Islam's history. The Islamic endowment system developed thereafter into a phenomenon that is present in virtually all Islamic societies and which has a high prestige in social, religious, political, cultural and economic terms.

It is possible to speak of a single principle underlying Islamic pious endowments, even if the various Islamic schools of law differ on some major points and, especially, the widespread distribution of the awqā $f$ has meant that they exhibit a variety of different local legal and administrative practices. ${ }^{17}$ The act of endowment inalienably dedicates something to a pious goal (qurba). The donor gives part or all of his property to the pious goal and specifies, usually in an endowment charter, the purpose of his endowment and the conditions of its use. The object thus endowed must serve a goal pleasing to God and the overwhelming majority of learned opinions agree that the endower has to renounce all rights to ownership in perpetuity. In this way the waqf comes under the claim of God (haqq Alläh). ${ }^{18}$ This religious aspect of the pious endowment gave the endower a comparatively high degree of protection from state interference, quite apart from the satisfaction of having done a good deed for his community of fellow believers. The eternal nature of

\footnotetext{
11 Stillman 1975, 107.

12 See further Wippel 1996, 20, fn. 74; on zakāt in Pakistan, see Nienhaus 1982, 194-204.

13 Qutb 1979, 150. In his book, Social Justice in Islam, he devoted the question of zakāt a chapter, see ibid., 150-57. This book was translated into English by Shepard.

14 Qutb 1979, 151.

15 See al-Qaradāwī (n.d.) (on al-Qaradāwī, see also http:/ / www.qaradawi.net); on the zakāt conception of Ramadan, see Frégosi 2000, 212; Qutb 1994, 85-89; Almisry 1985, 67-80.

16 Hodgson 1974, 124.

17 For the development of the theoretical framework of the legal apparatus of the pious endowments in Islam, see van Leeuwen 1999, 33-66.

18 Hoexter 1995.
} 
a pious endowment means that it is of necessity also inalienable, and thus is excluded from free trade.

There are many divergent opinions about what can form an Islamic endowment. Articles such as books for students and scholars, and weapons for the fight against the unbelievers are indeed donated, but it is generally property, the income from which serves the pious goal, minus maintenance and administration costs. It is easier to fulfil the requirement that an endowment should be for eternity with unmoveable goods.

The two most well known forms of Islamic pious endowment are the public (waqf khairī $/{ }^{c} \bar{a} m m$ ) and the private, family endowment (waqf ahlìl $k h \bar{a} s ̦$ (dhurrì). The income from a public endowment goes directly towards a communal goal, whereas the income from a private endowment benefits a circle of people nominated by the endower. Either the endower himself or a representative chosen by him controls the endowment. The administrator comes under the authority of a Qadi on the local level and, depending on the degree of centralisation of the Muslim state in question, the Qadi is in turn subject to hierarchical control mechanisms with the ruler at the top.

While there is widespread agreement among Islamic legal scholars that the goal of pious endowments is to carry out work pleasing to God, the definition of qurba, one of the fundamental authorisations of the Islamic pious endowment, is rather broader. ${ }^{19}$ It may be seen as relating to the financing of the religious infrastructure of Islam, i.e. the construction and maintenance of mosques, the payment of religious employees, the financing of the traditional Islamic education system, the encouragement of Islamic scholarship and culture or to the safeguarding of fundamental requirements for welfare and community. Thus caring for sick storks ${ }^{20}$ promoting the construction of the Hijaz-railroad ${ }^{21}$ or even housing prostitutes in pious endowment property ${ }^{22}$ can be seen as demonstrating the piety of the endower.

Pious endowments in Muslim states took on a great number of tasks that are commonly seen as the achievements of contemporary welfare states. Provision for the poor and needy, the maintenance of sanatoriums and hospitals and so on are seen as traditional areas of responsibility which were covered by $a w q \bar{a} f$. In the absence of a modern European concept of municipal administration of public institutions such as the operation of public baths, pious endowments were responsible for the fundamental interests of the community. Central functions such as supplying water to towns via the construction of aqueducts and wells are examples of the importance and social status of pious endowments. ${ }^{23}$

\footnotetext{
19 Hoexter 1987, 187-89.

${ }^{20}$ Luccioni 1982, 98.

21 See further Ochsenwald 1976

22 Bouhdiba 1985, 190.

23 Raymond 1985, 155-67.
} 
The construction and maintenance of mosques, the payment of religious employees or the financing of the Islamic educational system gave the endower not only high personal prestige but also allowed him to exercise influence over the contents of Islamic teachings. The Islamic scholars ( $\left.{ }^{c} u l a m \bar{a}^{\top}\right)$, as the bearers and transmitters of Islamic scholarship, profited just as much from pious endowments as students of Islamic sciences whose fundamental requirements were covered by grants.

\section{Pious Endowments in Morocco}

Islamic pious endowments have also had a lasting effect on the lives of Muslims in Morocco. ${ }^{24}$ Their flourishing, and also their decline, was closely connected to the changing fates of the ruling dynasties. A ruler's motivation for creating a climate favourable to the foundation of pious endowments could have many causes. As leaders of the believers (amīr al-mucminin), the Sultans of Morocco were of course duty-bound to ensure there was an infrastructure in place which allowed Muslims to carry out their religious duty. The desire to show piety, to satisfy a hunger for prestige or the simple thirst for power led to the construction of many mosques and educational establishments which passed the contents of Islamic scholarship from generation to generation.

Generous endowments in the name of the community could however also serve as a means of consolidating and expanding political influence via the careful regulation of what was taught. This was the case for example during the thirteenth and fourteenth centuries under the Banū Marin, the Marinid rulers. ${ }^{25}$ Their generous endowments in the educational field laid the foundation for the dominance of the Malīkī school of law in Morocco. Even today, the institutions of higher education (madrasa/madāris) founded under the Marinid rulers remain architectural masterpieces, and in addition, they caused the foundation of numerous welfare-oriented pious endowments, including ahbās which supported Muslims in distress. ${ }^{26}$ They had special houses for the elderly and hospitals (māristānāt) were built in several towns. ${ }^{27}$ Pious endowments for the poor (ahbās al-masakin) carried out the ritual circumcision of orphaned boys, gave clothing and food to the needy, paid for the burial of the poor and strangers, or financed the marriages of destitute subjects. Endowed zawāyā gave shelter to traders and travellers, while the purpose of other pious endowments was to purchase the freedom of prisoners of war who had been sold into slavery. ${ }^{28}$

\footnotetext{
24 On the pious endowments of Morocco see Luccioni 1939 and ibid., 1982 as well as Būrakba 1996. On the Moroccan $a h b \bar{a} s$ until Mawlay Ismā' (1672-1727) see Balmuqaddam 1993; on the Moroccan $a h b \bar{a} s$ under the French protectorate see Kogelmann 1999.

25 See further al-Mannūnī 1983.

26 On the madāris of Morocco see Péretié 1912 as well as Luccioni 1982, 79-93.

27 Al-Mannūnī 1983, 27-30.

28 At-Tāzī 1995, 57-64.
} 
The flourishing and the decline of pious endowments were dependent on many factors and were closely linked to the fate of the ruling dynasty. Regardless of whether any economic prosperity was the result of the ruler's personal initiative or had its origins in the domination of the Iberian peninsula, the Sudan or other areas in the Maghreb, it always had positive effects on the development of pious endowments. Political stability, favourable conditions on and control of the trade routes were ideal conditions for endowments to blossom. In addition, effective administration meant that pious endowments were able to fulfil their social duties.

A clear pattern can be discerned in the administration of pious endowments in Morocco. On account of their religious character, the main responsibility for the pious endowments formerly lay with the Qadi, but state reforms even before the advent of French rule aimed to increase the control that the makhzan, the Moroccan government, had over the endowments. This was with the goal of placing them in the service of central state interests should the need arise. ${ }^{29}$

Economic decline, political unrest, the increasing involvement of European powers in the internal politics of the country and the failure of state reforms towards the end of the nineteenth century all had negative effects on the Moroccan endowment system. ${ }^{30}$ The administrators of pious endowments neglected their duties and even members of the Sultan's entourage did not shy away from enriching themselves at the expense of Islamic endowments. However, it is impossible to gain an objective picture of the state of the ahbās towards the end of Morocco's independence, as there are no reliable sources of information to make possible a quantitative analysis of the squandering of endowed property during this period. Power struggles, wars, natural catastrophes and so on have been recurring features of Morocco's history that have had lasting effects on pious endowments but have never yet quite managed to destroy this Islamic institution.

\section{Moroccan Endowments under French Rule}

The creation of the French protectorate in 1912 produced the foundation for fundamental state reforms. ${ }^{31}$ The Treaty of Fez, which became the basis of 40 years of protective domination, gave France carte blanche to mould the country according to its ideas and requirements. The first article of the treaty gave the government of the French Republic the right to construct a new system on the basis of administrative, legal, educational, economic, financial and military reform "que le gouvernement français jugera utile d'introduire sur le

29 Kogelmann 1999, 67-148.

30 On the political, social and cultural development of Morocco before the establishment of the French protectorate see Burke 1976; Laroui 1993; al-Mannūnī 1985; on the development of the pious endowments in the years before 1912 see Kogelmann 1999, 114-44.

31 See further Bidwell 1973; Rivet 1988. 
territoire marocain." ${ }^{32}$ At the same time, the French government committed itself to refraining from interfering in all questions relating to the Islamic religion and promised to leave all Islamic institutions, especially the pious endowments, under the patronage of His Sharifian Majesty the Sultan of Morocco.

Under French rule, the Moroccan endowment system changed radically within 15 years. Because of their religious character, the ahbās did indeed officially come under the sphere of control of the Muslims, but the decisive impulses for reform in fact came from the French administration. ${ }^{33}$ All the regulations applying to the pious endowments were standardised on a national basis and the entire system was placed under a modern ministerial bureaucracy. The administrator of an endowment was no longer responsible to a locally appointed Qadi but accountable to the minister in Rabat. During French rule, the endowment system, which had previously run in deficit and had hardly been able to maintain its own property at the start of the twentieth century, let alone fulfil its welfare obligations, grew into an organisation run on commercial principles which constructed entire quarters of Casablanca, Meknes or Rabat. ${ }^{34}$ The continually rising annual returns evidenced a huge increase in efficiency and this caused even the religious establishment to forget-at least for about twenty years-that control over the pious endowments was no longer in Muslim hands but those of French functionaries. ${ }^{35}$

The modern endowment system in Morocco largely concentrates on the preservation and financing of the religious infrastructure. The maintenance of mosques or the support of Islamic scholarship are certainly goals pleasing to God, but can be seen only indirectly as social welfare activities. ${ }^{36}$ However, the Moroccan endowment system includes many aḥās that are exclusively welfare-oriented, and under French rule, the pious endowments for the māristān Sidi Fredj, known as aḥbās al-māristān, were the most important and rich in tradition of this kind.

Māristānāt, originally a term for hospital derived from the Persian, have a long tradition in Morocco. Whilst the physician and philosopher Ibn Rushd, known in Europe today as Averroès, practised in the māristān in Marrakech in the twelfth century, the few remaining māristānāt were largely in a state of decline at the beginning of the twentieth century. Worthy of

32 Bulletin Officiel, Vol. 1,1, p. 1.

33 Kogelmann 1999, 149-298.

34 Stöber 1986, 71-77.

35 This is the impression one gets from the official pronouncements of the leading ${ }^{c} u l a m \bar{a}^{\top}$ see Compte-rendu de la session du Conseil supérieur des Habous tenue du 6 au 10 Novembre 1915 au Dar Elmakhzen à Rabat of 25 November 1915, in MAE-ADN CD 510; and Gaillard 1915 as well as Wizārat (n.d.).

36 On social welfare and charity of Islamic endowments in general see Hoexter 1987, on philanthropic Islamic endowments before the modern era see Arjomand 1998 and in the contemporary Islamic world see Kozlowski 1998.

37 See further Dunlop/Colin/Sehsuvaroglu, bìmāristān, in Encyclopaedia of Islam (new edition). 
mention in this context are, apart from the māristān Sidi Fredj in Fez, the māristān Sidi Ben ${ }^{\mathrm{C}}$ Ashir in Salé and the māristān Si Muhammad al-Ghazi in Rabat.

The māristān Sidi Fredj was originally a fully-equipped hospital maintained by pious endowments. However it was already in a state of decline in the sixteenth century when Leo Africanus worked there as a secretary ( ${ }^{c}$ adl) during his studies. In his Description de l'Afrique, Leo describes the contemporary conditions:

The hospitals are impoverished and almost without means. (...) For the sick who are not from Fez, there is today but one hospital. There neither medicine nor care is given. The poor invalid has only his room, his ration and someone to take care of him until he should either die or be cured. In this hospital there are a few rooms reserved for lunatics, i.e. for maniacs who throw stones or commit other misdeeds. There they are put in iron chains. (...) The one who is charged to give the lunatics something to eat, if he sees one of the agitated, bastes him hard with a stick which he takes for this usage constantly with him. (...) After all, this hospital does have the persons necessary: secretaries, nurses, wardens, cooks and others who care for the invalids.

Leo Africanus explains this negative development by pointing to the fact that Moroccan Sultans had annexed the pious endowments for their war chests. By the end of the nineteenth century the māristān Sidi Fredj existed solely as a sanatorium for the mentally ill. Even if medical treatment by a doctor was no longer assured even in Leo Africanus' time, one curiosity did survive until the beginning of the twentieth century; a pious endowment provided for a weekly concert for the inmates as a kind of forerunner of modern music therapy. The māristān Sidi Fredj was responsible not only for the accommodation and, originally at least, the medical treatment of sick people, but-in the words of Edward Westermarck-“a great part of the funds to maintain the hospital used for the treatment of lunatics at Fez 'has been bequeathed by the wills of various charitable testators for the express purpose of assisting and nursing sick cranes and storks, and of burying them when dead'." 42

Not only did the ahbōs al-māristān comprise endowments for medical purposes in the widest sense, but also included ones that were without a precise definition of who was to be the beneficiary, and helped the poor in general. The income from these endowments was used on the one hand to give the poor a proper burial, and on the other, to help the needy. The charitable aid included feeding the poor and distributing clothing at certain Islamic holidays and at the beginning of winter. ${ }^{43}$ Other endowments within

38 Luccioni 1982, 96-101.

39 l'Africain 1981 I, 188, translation by the author.

40 Ibid., 187-88.

41 Luccioni 1953, 463.

42 Westermarck 1926 II, 330, he cites Ali Bey, Travels in Morocco, London 1816, 74. See also Meakin 1986, $70 \mathrm{ff}$.

43 Luccioni 1953, 463. 
the ahbās al-māristān had specific, defined beneficiaries. The income from the ahbuas al-māristān provided the means for survival for 500 inhabitants of the so-

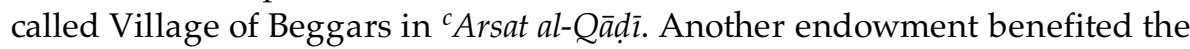
blind exclusively, and the so-called Dār al-Kitūn was intended for impoverished sharifas, i.e. the female descendants of the Prophet, on the one hand, and on the other for sharifas who wanted to escape their husband's authority. ${ }^{4}$

At the time of the French take-over, the Moroccan endowment system was in a condition that reflected that of the country as a whole, and Sidi Fredj was no exception. Its population was reduced to a handful of mentally ill patients in chains, imprisoned women and their wardens, and the nursing was limited to two pieces of bread and water a day. 45

The reform of the endowment system in general naturally had an effect on the $a h b \bar{a} s$ al-māristān. The administrator of the endowments became part of a hierarchical bureaucracy under close French supervision, and local administration was marked by precisely defined responsibilities and guidelines. First of all, a central inventory was made of the immovable property of the ahbuas al-māristān and the local administration was required to keep regular accounts. The administration was now answerable for all its activities to the newly-created ministry in Rabat, and the income from the endowments was to be paid into the central bank. Any expenses which went beyond the very modest limits set for local administrators had to be approved by the ministry. The most important goals were the upkeep of the majority of pious endowments and the maximisation of profit from them. ${ }^{46}$

The income from the Moroccan endowment system was primarily used to finance the religious infrastructure. In the first years of the protectorate, social welfare amounted to just seven per cent of the total expenditure in the ministry for pious endowments. Although the aḥbās al-māristān spent slightly more than half of the budget on charitable works, this constituted about 65 per cent of the total expenditure on social welfare. It is rather surprising, however, to discover that the expenditure of the ahbās al-māristān with regard to the māristān Sidi Fredj itself was minimal; in 1914 it amounted to a mere one per cent of the total. ${ }^{47}$

This low level of support for Sidi Fredj requires some explanation. Because the care provided by the pious endowments relating to this particular $m \bar{a} r i s t \bar{a} n$ was limited to feeding the patients, expenditure was of course very low. Medical treatment had not been available for a long time and the population preferred to rely on the healing power of a holy man's baraka, the

\footnotetext{
${ }^{44}$ Luccioni 1982, 152.

45 Luccioni 1953, 463. On the blessing and healing power of "lunatics" in pre-modern Moroccan society see Westermarck 1926 I, 47-50.

46 Kogelmann 1999, 164-73, 217-31.

47 Gaillard 1915 annexe 2; Wizārat (n.d.), 37-38. In the year $1332 \mathrm{~h}$ the total expenditures of the ministry for Islamic endowments amounted to $1,363,526.66 \mathrm{PH}$, the total amount of charity or social welfare expenditures ran up to $100,371.69 \mathrm{PH}$, with a share of ahbās al-māristān of $64,178.75$ PH. The amount of the hospital Sidi Fredj was only 625.18 PH.
} 
beneficent force of Sidi Fredj. ${ }^{48}$ I believe that the key to understanding the situation lies here. There were no Moroccan doctors in the European sense at this time, but marabuts and barbers tried to deal with the afflictions of the Moroccan people. The nineteenth century saw a few European doctors working in Morocco as a colonial advance-guard, but only a tiny fraction of the population were able to take advantage of their treatment. After the protectorate had been established, France began to build up a civil and military health system. The civil health system was largely centred on urban areas with a high European proportion of the population and was constructed hierarchically in line with the political maxims for the administration of the protectorate. Only Europeans and the upper classes of the local population had access to modern hospitals and well-trained European doctors. The medical treatment available to Jews was adequate, but the vast majority of the Muslim populace remained poorly cared for. The military health system was in turn a means for pacifying the rural population. ${ }^{49}$

The primary aim of the Service de Santé was to check the endemic-epidemic diseases which were rife among the Moroccan population and, compared to this monumental task, the care of a handful of the mentally ill in the māristānāt seems of marginal significance. However, the relatively low levels of outlay that the pious endowments expended on hospitals exclusively for the mentally ill were at least partially justified when the typhus epidemic struck in the winter of 1914 and thousands of emaciated Muslims were concentrated in encampments outside the town walls. Together with the protectorate administration, pious endowments and prosperous Muslims ensured that the basic needs of the people in quarantine for food and clothing were fulfilled. ${ }^{50}$ So-called welfare committees (Comités de bienfaisance musulmans) were formed by prosperous Muslims to support the suffering. Many of them did not stop at single, isolated acts of charity but remembered their religious duty of charity and called for a tax for the poor to be paid by the more prosperous sections of Moroccan society.

The decisive occurrence in awakening the Moroccan bourgeoisie to the social suffering of their religious brethren was the famine catastrophe in the south of the country in 1927. When Meknes was threatened by a tidal wave of refugees, the Pasha and the president of the local Société indigène de bienfaisance decided to impose an extra tax on rich Muslims "pour nourrir, vêtir, soigner les misérables." ${ }^{51}$ From this point onwards, the Moroccan bourgeoisie agreed to the conversion of numerous pious endowment buildings into hospitals and clinics.

Apart from converting property into hospitals, the Muslim establishment began to pay attention to the traditional māristānāt. Although significant

\footnotetext{
48 Luccioni 1953, 462.

49 See further Paul 1978 as well as Rivet 1988 II, 224-41.

50 Ibid., 236.

51 Ibid., 239.
} 
construction work had been undertaken by the pious endowments, the influence exercised by the endowments' administration over this form of social welfare declined continually. Muslim charitable organisations took over the administration of the māristānāt in Salé and Meknes after they had been renovated and expanded, but the ministry for pious endowment continued to subsidise these institutions. Only the māristān in Rabat remained under the aegis of the endowment administration. ${ }^{52}$

Time also brought improvements to the māristān Sidi Fredj. ${ }^{53}$ These included a renovation of the buildings, an increase in the food ration and the introduction of minimum standards for hygiene. The number of staff was increased and they received training, and the patients even began to receive regular medical treatment. However, the centuries-old building was in constant need of repair and the endowment administration finally decided to start from scratch, and a new māristān was constructed on a different site, although not without the intervention of the religious establishment to smooth over objections from some sections of society. Built according to the latest psychiatric theories, the māristān Sidi Fredj was inaugurated by the prominent citizens of Fez in 1951. The ahbōs al-māristān financed the construction and provided part of the running costs and, although it remained a pious endowment, the Direction de la Santé Publique and a committee chaired by the Pasha of Fez took over the running of the māristān.

\section{Conclusion}

European rule of Morocco did indeed lead to industrialisation in some areasalthough the majority of the local populace was excluded from it-but this economic development was not the start of social welfare for Muslims in the country. More to the point, Muslims witnessed changes in their traditional forms of social welfare, and in particular in the Islamic endowments. On the one hand, the pious endowments became more tightly organised and economically efficient, and on the other, the administrative centralisation process meant that this previously highly autonomous form of welfare now fell outside the area of responsibility of the local community. The Islamic pious endowments were placed within the competence of a centralised and Frenchdominated state. The 'nationalisation' of the Moroccan endowment system which began with the creation of the French protectorate did not lead directly to the nationalisation of Muslim social welfare in general. Sections of the Muslim population reacted to this development by founding local welfare organisations that were independent of Islamic pious endowments.

\footnotetext{
52 Luccioni 1953, 464-65.

53 Ibid., 465-70.
} 


\section{Bibliography}

\section{Unpublished archive material}

MAE-ADN CD Ministère des Affaires étrangères, Centre des Archives diplomatiques de Nantes, Cabinet diplomatique

\section{Books and articles}

l'Africain, Jean-Léon (1981). Déscription de l'Afrique. Nouvelle Edition traduite de l'Italien par A. Épaulard, Paris, first edition 1956, new impression 1981.

Ahmed, Munir D. (1988). "Soziale Sicherung", in Der Nahe und Mittlere Osten. Band 1 Grundlagen, Strukturen und Problemfelder, U. Steinbach und R. Robert (eds), Hamburg, 545-54.

Almisry, Abd Assamii (1985). Islamic Economics in Sonnah, Cairo.

Arjomand, Said Amir (1998). "Philanthropy, the Law, and Public Policy in the Islamic World before the Modern Era", in Philanthropy in the World's Traditions, W.F. Ilchman, St.N. Katz and E.L. Queen II (eds), Bloomington, 109-32.

Balmuqaddam, Ruqayya (1993). Awqāe Maknās fì c ahd Mawlay Ismāc $\bar{\imath} l$ (m 1727-1672, h 1139_ 1082), al-Muhammadiyya.

Barry, Jonathan/ Colin Jones (eds) (1991). Medicine and Charity before the Welfare State, London.

Bidwell, Robin (1973). Morocco under Colonial Rule. French Administration of Tribal Areas 19121956, London.

Bouhdiba, Abdelwahab (1985). Sexuality in Islam, London.

Būrakba, SaC̄d (1996). Daur al-waqf ficl-hayāt ath-thaqäfiyya ${ }^{c} i^{c} l$-maghrib fì ${ }^{c}$ ahd ad-daula al- ${ }^{c}$ alawiyya, ar-Ribāt.

Burke, Edmund (1976). Prelude to Protectorate in Morocco. Precolonial Protest and Resistance, 18601912, Chicago.

Cunninghame Graham, R.B. [1898] (1988). Mogreb-El-Acksa, London, first published 1898, new impression 1988

Encyclopaedia of Islam. New Edition. Leiden.

Foucauld, Charles de [1888] (1999). Reconnaissance au Maroc, Pairs, first published 1888, new impression 1999.

Frégosi, Franck (2000). "Les contours discursifs d'une religiosité citoyenne: laïcité et identité islamique chez Tariq Ramadan", in Paroles d'islam. Individus, sociétés et discours dans l'islam européen contemporain, F. Dassetto (ed.), Paris.

Gaillard, Henri (1915). La Réorganisation des Habous au Maroc. Rapport de M. Gaillard, Secrétaire Général du Gouvernement Chérifien à M. le Commissaire Résident Général de la République Française au Maroc sur la Réorganisation des Habous. Compte-rendu de la Session du Conseil Supérieur des Habous. Tenue du 6 au 10 Novembre 1915 au Dar Maghzen, à Rabat, Rabat.

Harris, Walter (1994). Le Maroc au temps des sultans, Paris. New impression of Le Maroc disparu, anecdotes sur la vie intime de Moulay Hafid, de Moulay Abd El Aziz et de Rä̈souli, Paris 1929.

Hodgson, Marshall G.S. (1974). The Venture of Islam. Conscience and History of a World Civilization. 2 The Expansion of Islam in the Middle Periods, Chicago.

Hoexter, Miriam (1987). "The Study of Charity-a Case Study in Continuity and Flexibility of an Islamic Institution", in Wissenschaftskolleg zu Berlin, Jahrbuch 1985/86, 179-89.

- (1995). "Huqūq Allāh and huqū $q$ al- ${ }^{c} I b \bar{a} d$ as Reflected in the Waqf Institution", Jerusalem Studies in Arabic and Islam, 19, 133-56.

Kogelmann, Franz (1999). Islamische fromme Stiftungen und Staat. Der Wandel in den Beziehungen zwischen einer religiösen Institution und dem marokkanischen Staat seit dem 19. Jahrhundert bis 1937, Würzburg.

Kozlowski, Gregory C. (1998). "Religious Authority, Reform, and Philanthropy in the Contemporary Muslim World", in Philanthropy in the World's Traditions, W.F. Ilchman, St.N. Katz and E.L. Queen II (eds), Bloomington, 279-308.

Laroui, Abdallah (1993). Les origines sociales et culturelles du nationalisme marocain (1830-1912), Casablanca.

Leeuwen, Richard van (1999). Waqfs and Urban Structures. The Case of Ottoman Damascus, Leiden. 
Luccioni, Joseph (1939). Le Habous ou Wakf (rites malékite et hanéfite), Casablanca.

- (1953). "Les Maristanes du Maroc. Le nouveau maristane de Sidi-Fredj à Fès", Bulletin Economique et Social du Maroc,16(58), 461-70.

- (1982). Les Fondations Pieuses «Habous» au Maroc depuis les origines jusqu'à 1956, Rabat.

al-Mannūnī, Muhammad (1983). "Daur al-awqf al-maghribiyya fi't-takāmul al-ijtimāç cabra 'asr banū Marīn (657-869 h)", Dac wat al-haqq, (230), 27-35.

- (1985). Mazāhir yaqzat al-Maghrib al-hadìt, ad-Dār al-Baida.

Meakin, Budgett [1901] (1986). The Land of the Moors. A Comprehensive Description, London, first published 1901, new impression 1986.

Michaux-Bellaire, Edouard (1920). "Les crises monétaires au Maroc", Revue du Monde Musulman, Vol. 38, 41-57.

Miège, Jean-Louis (1962). Le Maroc et l'Europe (1830-1894), Paris.

Mojuetan, Benson Akutse (1995). History and Underdevelopment in Morocco: The structural roots of conjuncture, Münster.

Müller, Herta (1997). "Staat und informelle Wirtschaft in Marokko", wuqûf 10-11, Beiträge zur Entwicklung von Staat und Gesellschaft in Nordafrika, 277-94.

Nienhaus, Volker (1982). Islam und moderne Wirtschaft. Positionen, Probleme und Perspektiven, Graz.

Ochsenwald, William (1976). "A Modern Waqf: the Hijaz Railway, 1900-48", Arabian Studies, 3, $1-12$.

Paul, Jim (1978). "Medicine and Imperialism in Morocco", Merip Reports, 7(60), 3-12.

Péretié, A. (1912). “Les Medrasas de Fès", Archives Marocaines, 18, 257-372.

Pinker, Robert (1980). The Idea of Welfare, London.

al-Qaradāwī, Yūsuf (n.d.). Figh az-zakāt: dirāsa muqārina li-ahkāmihā wa-falsafatihā fì dau alqur ${ }^{3} \bar{n}$ wa $w a^{3}$ s-sunna, al-Qāhira.

Qutb, Muhammad (1994). Islam the Misunderstood Religion, Lahore.

Qutb, Sayyid (1979). al-c Adāla al-ijtimāc ${ }^{c}$ iyya fìl-islām, al-Qāhira.

Raymond, André (1985). Grandes villes arabes à l'époque ottomane, Paris.

Rivet, Daniel (1988). Lyautey et l'institution du protectorat français au Maroc 1912-1925, Paris.

Schroeter, Daniel J. (1988). Merchants of Essaouira. Urban society and imperialism in southwestern Morocco, 1844-1886, Cambridge.

Shepard, William E. (1996). Sayyid Qutb and Islamic Activism. A Translation and Critical Analysis of Social Justice in Islam, Leiden.

Stillman, Norman A. (1975). "Charity and Social Service in Medieval Islam", Societas, (2), 10515.

Stöber, Georg (1986). "Habous Public" in Marokko. Zur wirtschaftlichen Bedeutung religiöser Stiftungen im 20. Jahrhundert, Marburg/Lahn.

at-Tāzā, 'Abd al-Hādī (1995). "Tauzịif al-waqf li-khidmat as-siyāsa al-khārijiyya fỉl-Maghrib", in Le Waqf dans l'espace islamique. Outil de pouvoir socio-politique, R. Deguilhem (ed.), Damas, 5795 (arabic part).

Watt, W. Montgomery/Welch, Alford T. (1980). Der Islam I, Stuttgart.

Westermarck, Edward (1926). Ritual and Belief in Morocco, London.

Wippel, Stefan (1996). Islamische Wirtschafts- und Wohlfahrtseinrichtungen in Ägypten zwischen Markt und Moral, Münster.

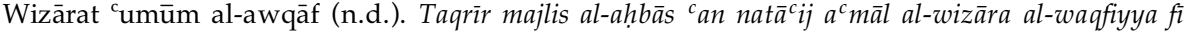
camai 1333 wa 1334.

Zabel, Rudolf (1911). Zu unruhiger Zeit in Marokko, Cöln am Rhein. 


\title{
CHAPTER IV \\ Sufism and Social Welfare in the Sahara
}

\author{
Knut S. Vikør
}

Sufi orders are often studied for the effects their existence and activity cause in their social, economic and political surroundings. ${ }^{1}$ This is partly because of the research interests of those who study Muslim societies, but sometimes also because of the influence of an ingrained Western conception of Muslim religious ideas as something divorced from 'real life', developing free from the social context in the minds of the religious specialists. While modern scholars of Muslim societies may reject such 'Orientalist' notions, they often perpetuate the conception of the dichotomy between 'ideas' and 'real life', only giving primacy to the latter, as opposed to the Orientalist focus on the former 'world of ideals'. Reading such studies of 'real-life' Sufi orders in the modern world, one can therefore often be forgiven for thinking that one is studying commercial corporations, anti-colonial movements, or social welfare organisations.

But when one starts reading the literature that the order spreads and the brethren study, one is transported into another world of piety and the search for an inner, religious experience; an individual aim of realising God, although organised in the collective form of a brotherhood. If the social and political surroundings of the order are mentioned at all, it is most often fleetingly, or woven into the pious context. From these writings, one would gather that the social and political activity that the order may or may not undertake, is a matter of little or no concern; something that is evidently not the case when we look at independent historical sources for what they actually did.

One way of explaining this apparent difference is to deny that the religious writings and the rituals undertaken by the brethren have any validity for the social reality (claiming, for example, that few ordinary brethren would have been able to read the writings of their scholarly masters). This would, however, be to assume that the leaders either were insincere in their pious writings, or that it is only by chance that a pious religious leader also heads an organisation for commerce, revolt or whatever.

It would be more fruitful to try to see how the two, the pious ideals and the social practice, are integrated. And such a unified approach must assume the primacy of the pious ideals, seeing the social and political consequences as

${ }^{1}$ See further the contributions by Seesemann (Chapter V) and Loimeier (Chapter VI) in this volume. 
results, side-effects, of the realisation of these pious ideals. Were it otherwise, we would have difficulty in explaining how other successful Sufi orders did not have social or political effects of note.

These effects on the temporal world, which often represent an alternative way of realising the social ideals, are thus not the result of an ideology different from that of other Muslims, but from the fact and manner of the organisation of this ideology, and the context it happened to grow in. The truth of this is easily seen in the political field when we look at the differential history of the Tijāni order in Africa, being non-political and rather pro-French in the Maghreb, while its dominant branch in West Africa was intensely political and eventually a major anti-French force. ${ }^{2}$ Yet their ideology and Sufi content were identical, indeed $a l-h \bar{a} j j{ }^{\mathrm{C}} \mathrm{Umar}$, the leader of the West African state-tarīqa, is recognised by Tijānīs everywhere as one of their major intellectuals, and his Kitāb al-Rimāh is read alongside al-Tijānī's own Jawāhir al$m a^{c} \bar{a} n \bar{i} .{ }^{3}$

This does not mean that we should not look for reasons and explanations for the growth of particular Sufi orders in social and economic developments of their surroundings. Clearly for example the development of the first organised Sufi brotherhood in West Africa, the Qādirīya Mukhțārīya around Sīdī al-Mukhțār al-Kuntī (d. 1811) was the direct result of the development of the Kunta as a major trading lineage in the Western Sahara from the mideighteenth century. ${ }^{4}$

The individuals who created the new and innovate structures, al-hâjj 'Umar and Sīdì al-Mukhtār, were dominant people both in the social field and in the field of piety and of ideas. They were both saints and successful economic or political entrepreneurs and not, it seems, one because of the other, although they were able to use their stature in one area to enhance their position in the other. It is among such rare coincidences of an exceptional stature in both fields that we find the innovations in both Sufi organisation and socio-political relevance. ${ }^{5}$

How the two are articulated will vary from case to case. However, Sufi ideas often require the pious experience to be organised in a particular manner, and this organisation may either presuppose certain social or political circumstances, which the nascent brotherhood then strives to implement, or the organisation leads unwittingly to certain changes by the mere fact of its existence, or through the vagaries of its development. The provision of social welfare in the community is evidently caused by an ethic inscribed in the pious ideal, but is even more a direct or indirect result of how the brotherhood is integrated into its social environment.

\footnotetext{
2 See further Abun-Nasr 1965, Martin 1976, 68-98, Vikør 1996a, 25-29 and Vikør 1996b.

3 That is, the two works are normally printed together. The Jawāhir carries the name of ${ }^{\mathrm{c}} \mathrm{Ali}$ Harāzim Barāda, but was read out to and approved by Ahmad al-Tijānī, the founder of the order, and is considered to express his teaching. See further Radtke 1995 and Hunwick 1992.

${ }^{4}$ See further Batran 1979, McDougall 1986 and Vikør 2000.

${ }^{5}$ Vikør 1996b and Vikør 2000
} 
A case in point may be the Sanūsīya brotherhood of the eastern Sahara, from the 1840s until its destruction in the 1910s and 20s. It has been studied more for its political and economic role than in terms of its ideas. ${ }^{6}$ We thus do not yet understand if or to what degree it marks an exception, or a deviation from a 'normal' paradigm of Sufi ideology, or whether it is a mere continuation of a quite traditional concept of Islamic mysticism. We do know, however, that its organisational structure was a novelty in the desert-side society where it settled, and led to a new social order for many of the members of that society.

The founder of the order, Muhammad b. ${ }^{\mathrm{c}}$ Alī al-Sanūsī, was born near Mustaghānim on the Algeria-Morocco border in 1787.7 From an apparently prosperous and scholarly family, he went first to Fez where he studied both exoteric and esoteric sciences, then to Cairo and finally to Mecca, where he joined another Maghrebi expatriate, Ahmad b. Idrīs, and became his most devoted follower and student. ${ }^{8}$

Ibn Idrīs was widely recognised as a Sufi teacher, but did not himself establish any Sufi order. This is not uncommon, it is often the second generation, the immediate successor of the great saint that organises his teachings and names the order after the patron. This happened only partly with Ibn Idrīs. His own sons did not take on the mantle of their father, and al-Sanūsì seems originally to have played the role of follower/organiser. ${ }^{9}$ Thus, alSanūsī was appointed as Ibn Idrīs's representative in Mecca when the teacher, apparently for political reasons, was forced to move to Șabyā in the Yemen. ${ }^{10}$ The students that al-Sanūsī took care of as wakil were those of Ibn Idrīs, not his own, and when he, after the death of the master in 1837, set out towards North Africa to found a brotherhood, it was in his master's name, not his own.

Thus, one might have expected the order that eventually was set up in Cyrenaica to become known as the Idrīsìya, not the Sanūsìya. Internally, it was always Ibn Idris's teachings that it dispensed and the wird, the distinguishing mark of any tarīga (Sufi Way), was that of Ibn Idrīs, not al-Sanūsì. In ideology it was the Idrisī Way. Yet the order never presented itself under this name, internally it called itself only the tariqa Muhammadiya, the Way of the Prophet Muhammad, and it was soon known to outsiders as the Sanūsiya order. ${ }^{11}$

There are many reasons for this. One, and probably the least important, was that al-Sanūsī was not the only successor to Ibn Idrīs. Another student, Muhammad 'Uthmān al-Mīrghanī had already in Ibn Idrīs's lifetime set up a

\footnotetext{
6 Among the most prominent of the many studies of the Sanūsìya, see Shukrī 1948, Evans-Pritchard 1949, al-Dajjānī 1967 \& 1988, Ziyadeh 1958 \& 1983 and Vikør 1995.

7 On the biography of the founder, see now primarily Vikør 1995, 22-180.

8 On Ibn Idrīs, primarily O'Fahey 1990, now enhanced by many articles by the same author and other studies on 'Idrīsī derivates' mentioned here.

9 See overview in Sedgwick 1998, 63-104; also Karrār 1992a, 43-78 and Karrār 1992b, 42-72, Ibrāhīm 1993, 275-87 \& 344-60, Bang 1996, 56-67, and Hofheinz 1996, 154-95.

10 Vikør 1995, 111-18.

11 Ibid., 143
} 
different structure in the Sudan, which came to be known as the Khatmiya, and yet another student, Ibrāhīm al-Rashīd later established a third separate order in the Sudan and out of Mecca.12 More were to follow. However, at the time of Ibn Idris's death, the only other Way that was in process of formation was the Khatmìya, and this was already moving away from Ibn Idrīs towards al-Mīrghanī as its focus of identity. Thus, the way lay open for al-Sanūsì's structure to become the Idrīisya. Ibrahìm al-Rashìd did initially follow alSanūsī, and was probably for a short time head of his lodge in Mecca, before he set out on his own. ${ }^{13}$ And when he did so, it was apparently just because he felt that al-Sanūsì's way was becoming more than just the heritage of Ibn Idrīs that it purported to transmit. In a sense, the disappearance of al-Rashìd marks the turning point when al-Sanūsì's new brotherhood in reality becomes the Sanūsiya, and not just the students of Ibn Idrīs.

A more fundamental reason for this change in identity was that alSanūsì, although he always humbly deferred to Ibn Idrīs in spiritual stature, was probably his equal in scholarliness, or close to it; he certainly wrote much more in the Islamic sciences, and in those few works of figh that we find from Ibn Idrīs's hand, we are not sure whose voice we are hearing, the master's or the student's. ${ }^{14}$ Thus, while the brethren were reading the prayers of Ibn Idrīs, they were studying the books of al-Sanūsì.

Also, when al-Sanūsì took the community from Mecca and started the trek to find a new home, he moved away from the regions where people knew or had heard much about Ibn Idrīs. When he was building up a social basis for his brotherhood by harnessing the mobilising power of sainthood, he could not draw on the distant awareness of his master. Consciously or not, he had to become the saint, the focus of mobilisation, himself. It was he who went round to all the major and minor tribal leaders and got them to support and sponsor his organisation, it was he who married into several of the leading families of the province, and soon it was new students recruited to him, not to Ibn Idris, that became the basis of his organisation (although the high council was dominated by fellow scholars recruited in Mecca, the older of whom had all met with and followed Ibn Idrīs).

This history shows some of the duality mentioned above. The Sanūsì experience had an internal, pious and ideological or religious side. This was dominated by Ibn Idrīs, always and down until today, and al-Sanūsī was only the humble student who passed on and commented on the message. But independent from this, it also had an external, organisational side, inserting it into the reality of the Saharan desert-side. And here it was al-Sanūsì himself who had to dominate, because he was the only one that could be present to the

\footnotetext{
12 Karrār 1992b, 55-72 \& 109-10, and Sedgwick 1998, 74-92.

13 Vikør 1995, 164-70. In the following, when not otherwise indicated, the discussion of the Sanūsiya is based on Sufi and scholar, with reference to in particular pp. 132-217.

14 This refers to Ibn Idrīs's attack on taqlìd in the brief and undated Risālāt al-radd, much of the same material can be found, almost verbatim, in al-Sanūsī's $\bar{I} q a z$ al-wasnān, but with much greater detail and inserted into a proper scholarly discussion. Thus it may not be clear who influenced whom; cf. Radtke et al. 2000, 2-3 \& 81-94.
} 
consciousness of the Bedouin society. Therefore he became both the transmitter and the founder of the experience that he developed.

\section{The Economic Role of the Sanūsīya}

In the early twentieth century, the Sanūsī order played an important political, anti-colonial role. However, before the unexpected and unprovoked French attack on the Bi ${ }^{3}{ }^{\mathrm{C}}$ Alālī Sanūsì lodge in Kanem in $1901,{ }^{15}$ it had no conscious political role beyond that of peace-maker between the local tribes or factions. The most noticeable 'exoteric' role of the order in this period was economic, through its insertion in the trans-Saharan trade.

When al-Sanūsī left Mecca to establish his new order, he first went to Tripolitania and southern Tunisia before he returned and settled in Cyrenaica, today's eastern Libya. This region was formally under Ottoman rule, but they only controlled the more fertile northern territory, south of the Jālu oasis. ${ }^{16}$ Beyond this, the camel-herding nomads in effect ruled themselves. The order set up its first lodge in $1841,{ }^{17}$ by the death of the founder eighteen years later it had acquired the support of most Bedouin groups in Cyrenaica, and also established a number of lodges in neighbouring Tripolitania, the Fezzan in the south-west, the Egyptian oases to the east and in the Kufra oasis in the desert to the south. It also had lodges in the towns of the region, and was represented as well in Mecca, Medina and other towns of the Hijaz.

In the latter half of the century, the main direction of expansion was to the south. It recruited both among Arab immigrants and among the Sudanic populations, in particular the Teda. ${ }^{18}$ It also made some contacts further southwest, with the Kawar oasis and trading centres of the Nigerian Sahel, but did not make much of an impact there before the turn of the century. However, some traders did join the order. The same situation applied in Wadai and Darfur to the south-east; there was no large implantation of the order as an organised structure, but a number of traders joined the Sanūsiya on an individual basis.

That the south was of importance to the order was shown by the decision to move the headquarters of the order from its university centre of Jaghbūb in Cyrenaica (which remained the scholarly centre) south to Kufra in 1895, then four years later to Qiru on the eastern edge of the Tibesti highlands. This latter was an area in which the order had only recently made contact and was only marginally implanted. It was however mid-way between the solid basis in

\footnotetext{
15 Triaud 1995, 611-42. This is the main source for the Sanūsī-French encounter; see also Triaud 1987.

16 Ciammaichella 1987, 23.

17 The al-Baydāā lodge, built 1841-42, some sources say only in 1843; Vikør 1995, 151 and Vikør 1996a, 189.

18 Triaud 1995, 437-94, and Vikør 1999, 240-49.
} 
Cyrenaica and the new regions of the south, and also within reach of the Fezzan and the areas further north-west. However, the French attack on their lodges made them reconsider their southern strategy from 1901, and in the following year, when the order's second leader, Muhammad al-Mahdi, died, Qiru was abandoned and the leadership returned to Kufra.

At the same time as the brotherhood focused its attention on the eastern Saharan and sub-Saharan regions, these areas also gained increased economic importance. The major avenues of trans-Saharan trade had successively moved eastwards, and from the mid-sixteenth century, the most profitable trade route was through the central Sahara from Borno across Kawar and the Fezzan to Tripoli, carrying slaves, ivory, and later ostrich feathers in exchange for fabrics, arms and ammunition and other luxury goods. ${ }^{19}$

However, in the nineteenth century this route became more difficult because of growing insecurity in the region. Borno had internal problems and was in conflict with its new western neighbour Sokoto, and the Teda of Tibesti were under increased population pressure and sought an escape by raiding the trans-Saharan caravans. The end of Fezzan's independence in 1811 did nothing to improve the situation. The last straw was when the Ottomans evicted the Awlād Sulaymān Arabs from the Fezzan thirty years later. ${ }^{20}$ Forced into exile in Kanem, the Bedouins started raiding the trans-Saharan caravans almost on a regular basis, partly for economic gain, partly to establish their political supremacy over the eastern desert-side; a control that was largely recognised by the 1860 s.

In this troubled situation, a new trade route grew up as a successor to the Tripoli-Borno route. It went from Wadai in the south, across Borku (Unyanga) and Kufra to Jālū in Cyrenaica and then Benghazi. ${ }^{21}$ A more unlikely route, because both termini were less prosperous than on the central Saharan route and because of the more difficult stretches of desert it traversed, this route had one main advantage: the Sanūsiya brotherhood. Apart from the termini themselves - where the order was present, but only in a marginal way-the whole eastern route passed through territory controlled by desert peoples who gave their allegiance to the Sanūsìya, primarily the Majābara and Zuwiya tribes, who were among the most devoted supporters of the order. The allegiance was often a formality - the brotherhood only claimed authority in religious affairs, not temporal ones-but it was enough to ensure peace between those who lived along the route.

Thus, caravans travelling here were spared the disruptive raids of the central route, and the fact that the most dangerous raiders, the Awlād Sulaymān, were among those most closely connected to the order, did not diminish the importance of this role. The Majābara and Zuwiya who straddled the route itself and previously had also raided any foolhardy traveller,

\footnotetext{
19 Vikør 1999, 233-40.

20 Ibid., 216-23.

${ }^{21}$ Cordell 1977, 21-36.
} 
became closely involved in the effort, as traders or providers of services, and thus also benefited economically from the prevalence of peace.

The presence of the order thus helped trade, and the route in one manner became the 'Sanūsi trade route'. This has sometimes led the order to be described primarily as a commercial enterprise, or even a kind of 'trading house'.22 That is however a misnomer and does not represent the role the order played.

The order as such did not take part in the trade. To what degree individual members were traders depended on the level of relationship they had in the organisation. To be 'a Sanūsī' could mean a number of things. The leadership of the order consisted of shaykhs, that is heads of the lodges and other local officials, who were appointed from the Sanūsī headquarters and under their direct orders, as well as other officials in Jaghbūb or Kufra, or travelling in the Sahara and desert on behalf of it. These were not traders, we know that the official emissaries stayed away from trade on their travels.

The ordinary members of the brotherhood were people from the tribes in whose area the lodge was built. Many of the rituals of the order clearly had a communal character, and all members of the society would take part in them, and thus identify themselves as 'Sanūsī brethren', although they otherwise continued their ordinary activities, as nomads, agriculturists or traders.

In addition, some traders outside the major Sanūsì areas made a point of 'adhering' to the order, as was the case in Zinder, Wadai and Darfur. They could in this way link up with the international network that the order provided. How far their commitment to the pious content of the Way went must of course be a matter of conjecture. No doubt it was to many only a symbolic attachment, paying lip service to the aims of the brotherhood. But there were Sufi structures established in these places, and for example in Zinder, the Sanūsì community survived the collapse of the trans-Saharan trade and, interestingly enough, kept themselves apart from the Sanūsi-led revolt against the French that swept through the Tuareg regions of Niger in $1916 .{ }^{23}$

Most of the desert regions that the order settled in lacked any form of state structure, Islamic or otherwise, or the outside authority was weak and unable to control the life of the tribes to any great extent. Here the brotherhood did take on social responsibilities.

The first and foremost of those was to promote peace. This was a prerequisite for any other activity. Without peace, the order could not fulfil any of its religious or pious objectives. The order clearly saw itself as having a 'civilising mission' connected to the spread of Islamic learning and piety. This led them to make connections with the leading members of the tribes. They asked them to send their sons to the lodges for religious and temporal education, a demand that was normally freely accepted. Their level of integration in the order beyond this would depend on how far they followed the

22 See e.g. Ciammaichella 1987, who goes far in seeing the order mainly as a commercial entity.

23 Triaud 1995, 826, and Vikør 1999, 268-70. 
teaching sessions of the shaykh and other local teachers. Some went to Jaghbūb for further study. Thus they would have abandoned for a time their own economic activity, but returned to it later; the order would not have been able to provide for all those who started a Sanūsì education. They came to identify with the order alongside the tribe, which remained the basic entity both socially and politically.

The role of the brotherhood in promoting social peace was thus primarily that of a facilitator and a provider of an identity for those Bedouins who wished to join them. This was also their main economic role, not as independent actors in exchange, but as sponsors who developed the framework in which this beneficial activity could prosper. There were several elements to this: The order created a network of contacts across the region which could be also used for commercial contacts. It developed a corps of guides that could lead trade caravans across the desert, and the brotherhood initiated digging of wells along the route. ${ }^{24}$ And the lodges of the order were built to be way stations for the traders; at reasonable intervals and with facilities for the caravans to stop over, rest and be provided for the next leg of the journey. Kufra, which housed the major Sanūsì centre in the period, was also a marketplace for the trans-Saharan trade, where traders making up the northern and southern legs of the trade exchanged goods. Jālū was also a market, while the southern centres of Qirū and Unyanga could not support such a market-place. The lodge also provided a more physical security, each lodge stored enough weaponry and ammunition to defend itself against those who might challenge the social peace, and the lodge was often built so it was easy to defend from attack.

The lodges were the central element of Sanūsī organisation. Established on land provided by the tribe or section that dominated in the region, they became the anchors that drew the various parts of the region together. The physical layout of the lodge followed a regular pattern. ${ }^{25}$ It should have separate quarters for each of the officials; a mosque; a school for the children; a guest-house and a shelter for the poor and those without families; and houses for the servants; as well as a bakery, stables, various storehouses and a garden. ${ }^{26}$ It was normally organised around a courtyard, with surrounding cloisters. ${ }^{27}$ Visiting traders would keep their animals in the courtyard. There might be a well inside the courtyard, or just outside. Visitors, that is traders, thus had special quarters, and were hosted and fed by the lodge for up to three days. They could also leave their goods in the lodge's storehouses for a period.

The lodge had to have enough land for the brethren and people connected to it to grow their own food. It must be emphasised that the lodges were mostly set up in oases with very little potential for agriculture, thus it would

\footnotetext{
24 Ciammaichella 1987, 31, and Cordell 1977, 32.

25 Vikør 1995, 189-92.

26 Al-Ashhab n.d., 28.

27 Slousch 1906, 179-80; describing the Daryāna lodge which he visited around 1905; also Insabato 1920, 72, and Ba ${ }^{c}$ ayy $\bar{u}$ 1953, 56.
} 
be wrong to consider them 'agricultural settlements', the agriculture was more in the nature of gardens. However, labour was an important element of the Sanūsī ideology. Stopping short of the 'labour equals prayer' attitude attributed to the Murīinya brotherhood, it emphasised the moral value of physical labour for all, al-Sanūsì talked of the 'equality' of labour of the hand and of the mind. Even the most senior scholars of the brotherhood had to sweat in the gardens or, even better, in building new lodges. Al-Sanūsì was keen to ensure that the lodges were actually built by the brethren themselves, and thus sought to recruit the required specialists (carpenters, blacksmiths) into the order. ${ }^{28}$

The resident brethren were asked to spend one day a week doing manual labour for the lodge. This, together with the less frequent input from the non-resident tribal members, was probably adequate for its needs. The lodge would also receive gifts, rather than regular tolls, from the traders who passed through, which helped with the upkeep.

In those regions where the order was the only authority, they in principle also took a zakāt tax of ten percent on the produce of the people who lived in the area. ${ }^{29}$ We cannot know to what degree this tax was regularly paid by people who had never paid any tax before and on whom the brotherhood had no physical means to impose their wishes. However, what they may have received was theirs to dispose of, they were granted freedom from taxes by the Ottoman authorities. The lodges and the land they were built on were given the status of waqf, that is tax-exempt, and that apparently extended to any income the lodges had. Of course, this was just an acceptance of the Ottoman authorities' inability to tax the Bedouins of the hinterland. ${ }^{30}$

\section{The Brotherhood and the Community}

That Sufi orders influence the social composition of tribal society is clearly nothing new. ${ }^{31}$ In the early developments of Sufi structures in the Sahara, identification with Islamic scholarship and piety functioned as a 'symbolic capital' that families, sections, lineages and tribes could use to better their social standing. To succeed, an entity must be 'strong', that is be able to mobilise resources or 'capital' of various kinds. Successful entities attracted others, making these redefine themselves as part of the stronger factions. Weakened entities descended on the social ladder or disappeared as separate entities, strengthened ones could ascend in type from lineage to fraction to tribe, as they attracted others. This is also the most probable explanation for the divide between 'noble' or 'warrior' as against 'client' tribes, not a genealogical given, but the changeable result of social ascent and descent.

28 Al-Ashhab n.d., 93, and Vikør 1995, 202.

29 Ciammaichella 1987, 17.

30 Beyond Jālū, see above.

31 See discussion in Vikør 2000. See also Cleaveland 1998, and McDougall 1998. 
In this power-play, military might and economic success were important elements to create a perception of power. But spiritual power was also very beneficial, and could be used to promote one's position. Thus 'scholarly' or 'holy' lineages did not have the might of the 'nobles', but could still entertain a higher status than the mere 'freedmen'. These lineages had then used such 'symbolic capital'32 to halt their descent, or to promote their ascent in society. Further, such a position could be transformed into economic capital, as was the case of the Kunta, who combined trade and saintliness.

The later Sufi organisation of the Sanūsiya could play a similar role. The brotherhood itself came from outside, and was thus not part of the Bedouin social structure, at least not in the first one or two generations. But they provided a strong source for symbolic capital for those who were able to draw benefit from it. This was clearly a reason why it was so enthusiastically welcomed by the various tribes of the region, no-one could afford to be left outside if other tribes or factions could draw on the order's status by association.

But it also affected the composition of the Bedouin social structure. In the nomadic society, power and success were measured in animals. Those whose capital diminished for one reason or another so that they could not feed their flock or their family, lost out and had to accept clientship to a stronger lineage or section. But with the arrival of the Sanūsì lodges, an alternative option appeared, one that still entailed social degradation, but could be economically viable and perhaps even give the hope of a return to a better life. The weakened group would settle in the shadow of a lodge, from which they received a certain amount of land belonging to the lodge. On this they could grow their own food; if this turned out to be insufficient, they could even get food directly as hand-outs from the lodge (presumably from the zakāt payments, where such were collected).

This was clearly a popular alternative for those families who accepted being settled. The lodge also benefited from it. It was normally given a certain amount of land by its hosting tribe as harām land. This meant that it was offered to the lodge, but only as far as it could cultivate it, the rest of the land remained for the benefit of the donating tribe. ${ }^{33}$ The size of this land was dynamic and could grow or shrink according to need or usage. Thus, by letting the poor members settle and grow their own food in the name of the order, the lodge could extend or secure its right to the donated land.

However, not only poor people flocked to be near the lodges. Also the rich would want to draw from this well of spiritual power, and built houses around the lodge, staying there during the summer when they were not nomadising. ${ }^{34}$ These houses were also built on lodge property, but were subject to special rules. Not owned by the tribal members, they could not be sold if vacated, but were, like the land itself, in the hands of the lodge. The

\footnotetext{
32 A term loosely borrowed from Bourdieu 1977, 176-83.

33 Vikør, 1995, 190-91.

34 Al-Ashhab n.d., 29, and Albergoni and Vignet-Zunz 1975, 231.
} 
land owned and used by the lodge could only be distributed by the shaykh, even though members of the donating tribe had settled on it.

All tribes were encouraged to send their youth to a lodge for education. Once a young student had entered the lodge, the family could not demand his return until the shaykh decided that he had finished his training. ${ }^{35}$ All male members of the tribe, including those who were not living near the lodge, had to perform two days' work for the lodge, one during the spring season and one during the harvest. ${ }^{36}$ Those nomads who lived close to the lodge were also required to take part in the prayers, presumably only the communal Friday prayer.

\section{The Sanūsīya and Social Relations: An Anthropological Debate}

That leads to the question of how the new Sanūsì establishment adapted itself to the social structure of the region. This has been a matter of controversy between two great anthropologists who both worked in the area.

The first was E.E. Evans-Pritchard, whose The Sanūsi of Cyrenaica is a seminal work both in the study of the Sanūsiya and in anthropological literature as a whole. He sees it as a prime case of structuralist adaptation. The other is a short article by Emrys Peters, originally a lecture held in Chicago in 1968 , but only published posthumously twenty-two years later. ${ }^{37}$ Peters did his fieldwork in Cyrenaica not long after Evans-Pritchard, but uses a quite different theoretical framework, and his article is a criticism both of EvansPritchard's theory and of the empirical findings that bolster it. As historians, we are less keen to intervene in the theoretical issues, as anthropology has no doubt long ago moved on from this debate on structuralism, but since the book is still considered an empirical authority on the Sanūsiya and the Bedouin, it may be worth looking at the main elements of the dispute.

The key point in Evans-Pritchard's understanding ${ }^{38}$ is that the Sanūsiya adapted to the Bedouin social structure by emphasising its neutrality, that is its externality, to the divides of tribal society. ${ }^{39}$ The order sought to build its lodges on the borders between the major tribal factions, so as to avoid being connected to any of them. In this way, it could build on the traditional role of the holy family known in the region and work as middle-men in disputes between the tribes. Through this externality, the order could become a neutral focus of authority common to all tribes, and thus the effective leader that realised its leadership potential when the Italian invasion came in 1911. This

\footnotetext{
35 Al-Ashhab n.d., 29.

36 Rinn 1884, 508, Azzam 1920, 245, and Shukrī 1948, 48.

37 Peters 1990, 10-28.

38 Cf. summary by Peters 1990, 10-16.

39 "So much was the Sanūsi organisation based on the tribal system that the distribution of the lodges may be said to have reflected tribal segmentation, mirroring lines of cleavage between tribes and between tribal sections", Evans-Pritchard 1949, 71-72.
} 
quest for externality also explains the continuing moving of the headquarters to the south, away from the Bedouin tribes and factions that the order became increasingly involved in.

Peters challenges Evans-Pritchard on one major point of fact. EvansPritchard states that the number of lodges in a region corresponds to the fractionness of the tribe. The large and cohesive Maghāriba tribe had only one lodge on its land, the small but fractious Darsa tribe had nine. ${ }^{40}$ But this does not, says Peters, correspond to the geographical distribution of Cyrenaican society. It is divided between a more fertile north with a denser and more cohesive population, and a south dominated by camel nomadism where existence is more precarious, and more factional tribes move over greater distances. As southern Cyrenaican society is much more fractious, EvansPritchard's theory requires there to be more Sanūsì centres there. But in fact, says Peters (using Evans-Pritchard's material), there are only four lodges in all of southern Cyrenaica, as opposed to more than forty in the north.

In fact, the placement of the lodges, and of Sanūsì interest, did not at all follow genealogical segmentation, says Peters. Instead it is congruent with power. Rather than seeking to be 'external' to the tribal segments, the order sought contacts with the most powerful leaders and contracted bonds with them, whether or not these individuals actually were the genealogical heads of the tribes. Also, it was important for the lodge to have an economic basis. What the Sanūsiss did, was to wait for an invitation from at least two tribal leaders to establish a lodge on their land. ${ }^{41}$ Then they went there, and the tribe put on as lavish a display of hospitality as they were able to. This gave the Sanūsì leaders an impression of the surplus production that the area could provide, and thus if it was sufficiently prosperous to support the establishment of a lodge.

The motivation of the order was not to merge with the tribal society of Cyrenaica, says Peters, criticising Evans-Pritchard's excessive focus on this region. This was only a stepping stone for the 'empire' 42 that al-Sanūsì wanted to build. Exactly what kind of 'empire' Peters thinks of, is not clear, but it is not a political one, he emphasises the order's disdain for political contacts and its desire to move freely across political boundaries.

The focus is rather on the trans-Saharan trade, the importance of which was clear from the beginning. Peters implies that al-Sanūsî, in addition to his religious aims (which he dismisses as 'impossible to know' and thus apparently to be ignored $)^{43}$ left Mecca for North Africa seeking a place to set up a trading network, primarily for slave trading. Intending to go home to Morocco, he turned back in Tunisia, not just because 'he found that' the French

\footnotetext{
40 Evans-Pritchard 1949, 72.

41 Peters 1990, 24.

42 Ibid., 26.

43 Ibid., 17.
} 
had occupied Algeria, ${ }^{44}$ but more importantly because he discovered the changes in the trans-Saharan trade route patterns. The western routes were declining, and in 'a place called Marzuk' [Murzuq, the capital of the Fezzan], ${ }^{45}$ a British consul was implementing anti-slavery measures, so al-Sanūsī went back east, to establish a new slave trading network from Benghazi to Wadai.

It is easy to follow Peters in his criticism of Evans-Pritchard's focus on Cyrenaica. Clearly, while this was a core area for the order, their interest was in spreading the order as widely as it could be done, not in merging with Cyrenaican society and becoming a 'tribe-brotherhood'. The Sanūsì message was a universal one, but it was to be spread carefully, starting with a solid base among the Bedouin and then moving out from there. While it was spread both in the towns and settled areas, there was however clearly an intent to focus on tribal or nomadic peoples, hence the greater effort to move south rather than towards the Nile valley-mostly ignored-or to the west beyond the Fezzan. Thus, Peters must be right in seeing the move of the headquarters as a move towards a new area of dissemination rather than away from either the Ottomans, with whom the orders always seem to have cordial although sometimes distant relations, ${ }^{46}$ or from the Cyrenaican Bedouin.

It is also correct that there was a development in the relationship between the brotherhood and the tribes, in that the brotherhood 'went native'. In the first period, most of the lodges were led by people from outside (mostly from neighbouring Tripolitania), and they circulated frequently, being appointed to one lodge after the other as the brotherhood expanded. Later in the century, the pattern was rather that the shaykh of a lodge stayed put until his death, and was replaced by his son or near relative. This made it possible for the local tribe or faction to identify more closely with 'its' own lodge and shaykh, rather than a more generalised identification with the brotherhood at large. This is clearly an example of 'normalisation' of the structure, the Sanūsì lodges became more like the standard pattern of close relations between a local community and 'its' holy or shaykhly family. The process of forging local links had already started with the founder, who shortly before his death insisted on marrying his two young sons into locally dominant families, to stabilise the authority basis of his successors.

Thus, the order's 'externality' must not be exaggerated. But it is also clear that Evans-Pritchard was right in pointing out its role as middle-man and peace-maker, and that it had to have some level of 'otherness' or externality to function in this role. It certainly also exploited the pattern of holy families in Cyrenaica, by building its lodges close to older qubbas of local saints. Thus, the

44 Peters here follows French misconceptions, but a simple chronology shows that this must be wrong. The French took Algiers in 1830, al-Sanūsì came to Tunisia in 1841. Evidently the Maghrebis resident in Mecca had been following the French advances closely during the decade, and al-Sanūsī would have had time to be updated on the latest developments during his several months in or near Cairo on the way west. He could also easily have evaded the French by moving through the desert, then still outside French control.

45 Peters 1990, 25

46 Vikør 1995, 208-10. 
first and largest lodge of al-Bayḍāa was built close to the grave of a Companion of the Prophet; and it was in fact located near the intersection of four major tribes. ${ }^{47}$

This need for an external anchor to ensure neutrality is of course common to Saharan peoples, one may point to the creation of the common 'sultan' (amenokal imeqqoran) of the Aïr Tuareg around 1400, to 'govern', that is mediate between the Tuareg drum-groups, who had to come from outside and have a scholarly background. ${ }^{48}$ His family probably stemmed from a scholarly ('holy') lineage near Timbuktu, the otherness was later strengthened by giving him a fictional ancestry from the Istanbul sultans. Thus certainly integrated in Tuareg society and himself a Tuareg, he was still 'outside'. The same was the case with the Sanūsìs, they were both 'internal' and 'external' to the society they worked in.

Peters' explanation of the Sanūsī motivation to settle in Cyrenaica because of exploiting the slave trade does not hold. He claims al-Sanūsī felt the disruption of the central trade route when he passed by Tripoli in 1840-41. But that disruption came only later, the turning point was the Ottoman invasion of the Fezzan in 1842, when the Awlād Sulaymān were evicted. Before then, the actors must rather have expected a more orderly and prosperous future for that route, with the replacement of the unruly situation under the Qaramānlīs with strict Ottoman authority. As mentioned, and as Peters agrees, the Sanūsiss did not fear Ottoman rule and worked well within their area. Also, there is no reason to emphasise the power of the British consul at Murzuq (where there were several Sanūsī lodges, and the Ottoman governor was a Sanūsī adherent). In fact, the slave trade over Murzuq was booming in 1840, it was only from the 1870 s and 80 s that it fell rather sharply to nothing. ${ }^{49}$ If the Sanūsiya thought about a commercial enterprise, they would in 1840 certainly have focused their attention on the Fezzan or Tripolitania, not on Cyrenaica.

This raises the point of the Sanūsīya's attitude to slaves and the slave trade. The sources are here quite diametrically opposed.$^{50}$ Later Arabic sources emphasise the Sanūsīs' loathing of slavery, and tell anecdotes of how their leaders when they came upon a caravan of slaves bought them all and set them free to return to their homeland. On the other hand, some French and other hostile observers saw the order as no more than callous slavers who built their wealth on other people's blood.

The truth is of course somewhere in between. There is no doubt that the Sanūsiss shared the general Islamic moral attitude towards slavery: that it is deplorable and that it is an act of piety to set slaves free, but that the institution itself is a fact of life. Thus, the anecdotes of the Sanūsis freeing black slaves and sending them home may well be true, even if exaggerated. It may even have

\footnotetext{
47 Ibid., 150.

48 Hamani 1989, 138, and Vikør 1999, 199-201.

49 Lovejoy 1984, 87.

50 Ciammaichella 1987, 17-24, and Vikør 1995, 188 \& 211.
} 
been a prudent prelude to later missionary work in the areas the slaves came from. .1

They also did not participate in the slave trade, because they did not participate in trade at all, as mentioned above. However, they did promote trade carried out by others, and the most important commodity that was traded was slaves for at least the first three or four decades after the Sanūsis came. Therefore, the order must have 'condoned' the slave trade as a legitimate enterprise.

As for whether slaves were used as menial labour in the lodges, some sources (of French origin) indicate that this occurred in the southern Sudanic (Saharan and sub-Saharan) lodges, while the northern lodges only relied on the manual labour of the Bedouin volunteers doing their civic duty. ${ }^{52}$ Other sources say that slaves acquired by the order were manumitted at once and settled on the land of the lodge, similarly to the poor Bedouin tribes, while some speak of manumission after a generation.

Given the haphazard nature of the information, and the lack of perception of distinction between actual slave, servile freedman or subaltern poor, one must be careful not to draw overly quick conclusions. The difference between north and south may simply have come from an informant equalling 'blacks' — of whom there were evidently more in the south - with 'slaves'. The assumption must be that the order would try to recreate the same structure of integration with the surrounding community in the south as in the north, where the voluntary labour for the lodge was an important part of this integration process. Thus, it would be best for the lodge, piety apart, if they could draw on all layers of society in working for the lodge.

However, we do know that an element of slavery or slave-like servility was a normal part of Teda and other Saharan society, in particular in agriculture which the nomads found demeaning. ${ }^{53}$ Thus, it cannot be excluded that there was in fact some usage of slaves or semi-slaves in the Sudanic lodges, either because the Teda refused to do the work, or simply as an adaptation to local social conditions. If so, it could also mean that the lodges' function as refuge for semi-sedentarised poor had not developed as far in the south as in the north (as these people could then be a source of voluntary labour). However, it must be remembered that the experience was much shorter in the south; the first lodges south of the desert only really came in the 1880s and the 1890s, and they were all crushed by the French by 1910 .

\footnotetext{
51 Although that was probably not important, most slaves came from pagan areas, and the Sanūsis concentrated their efforts on nominally Islamic regions in and around the Sahara, and they did not proselytise in polytheistic areas.

52 Ciammaichella 1987, 23.

53 Brandil'y 1988, 37-71, and Vikør 1999, 93-99.
} 


\section{Piety and Social Relations}

The economic and social effects of the Sanūsiya were thus the result of an interplay between choices made by the brotherhood and by the social actors of the surrounding community, choices that changed the nature of both. The brotherhood settled in the desert and spread in order to instil Islamic piety and learning in a part of the umma where this was lacking, and incidentally where there was no prior existence of competing Sufi orders.

In order to promote this pious ideal they must also effect some changes in this society, not to the political structure, which was left in place, but through the decrease of war and the progress of trade. This may or may not have been something al-Sanūsī was conscious of when he started his mission, but it certainly became clear to him before he got very far, thus his early insistence on providing services for the visiting traders in the lodges. In the context of promoting a pious ideal, the lodge became the central instrument, and with the lodge came certain economic consequences: the lodge had to survive and feed the non-productive activity of the scholars and the brethren.

For this, an input from the surrounding community was needed, and although the evaluation of the economic prosperity of the candidate tribe for hosting a lodge may not have been as callous as Peters describes-I have not seen a case where an invitation to build a lodge was turned down-clearly the establishment of a lodge generally implied that the local community could support it (with the exception of the capital Jaghbūb, which was built in an uninhabited and unproductive oasis, and whose foodstuff had to be imported).

The Bedouin also used the brotherhood for their own purposes. Primarily, it was a provider of spiritual or symbolic capital to be used in internal power struggles or the social processes of ascent or to halt descent of any given entity. By being 'external', neutral though pervasive and ever-present, as well as 'internal' and integrated, the order could provide such capital to all comers, while it might be counter-productive for any entity to try to oppose it (this only happened, in Kanem, when the French turned up and provided an alternative, external, source of power: at this point one half of the Awlād Sulaymān broke with the Sanūsīs and joined the French cause). ${ }^{54}$

The brotherhood's role in providing a source of 'social welfare' is thus inscribed into this dynamic relationship. For the families or lineage entities that were on the losing end of the scale, the brotherhood provided not only direct economic aid in terms of lending land for cultivation or by hand-outs, but also symbolic capital by attachment. In this way, the former nomads, although having to accept the humiliation of becoming sedentary, could mitigate this by their attachment to the spiritual power of the lodge and its shaykh. In this way, and perhaps also by sharing in the voluntary labour in principle provided equally by all members of the tribe, rich and poor, the degradation became more bearable. And allowing the families some land of

54 Triaud 1995, 477n, 515 \& 622, and Vikør 1999, 256-57. 
their own in the name of the lodge could at least give them the hope of rebuilding their fortunes and in the future getting animals of their own again to re-enter the higher social circles.

Thus, social welfare was provided not just directly for pious and moral reasons, but also as a side process of the general integration of the brotherhood with the surrounding social structure of the desert.

\section{Bibliography}

Abun-Nasr, Jamil M. (1965). The Tijaniyya: A Sufi order in a modern world, London.

Albergoni G. and J. Vignet-Zunz (1975). "L'Évolution du nomadisme pastoral en Cyrénaique", Annuaire de l'Afrique du Nord, xiv, 221-43.

al-Ashhab, Muhammad al-Ṭayyib (n.d., 1956?). Al-Sanūsī al-kabìr: ' Arḍ wa-tahlil li- dìcamat harakat al-ișlah al-Sanūsī, Cairo.

Azzam, A.R. (1920). "Heilige, Sekten und Religiöse Orden in Tripolis", Der neue Orient, Hamburg, vi: 6 1920, 243-47.

Bang, Anne K. (1996). The Idrisistate in ' Asìr 1906-1934, Bergen.

Batran, 'Abd al-'Aziz (1979). "The Kunta, Sīdī al-Mukhtār al-Kuntī and the office of shaykh alTariqa'l-Qādiriyya", in Studies in West African Islamic History, I, The Cultivators of Islam, John Ralph Willis (ed.), London, 113-46.

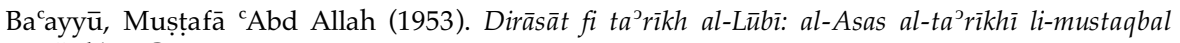
Lūbiyā, Cairo.

Bourdieu, Pierre (1977). Outline of a theory of practice, Cambridge.

Brandily, Monique (1988). "Les inégalités dans la société du Tibesti", in Gens du roc et du sable: Les Toubous, Catherine Baroin (ed.), Paris 1988, 37-71.

Ciammaichella, Glauco (1987). Libyens et français au Tchad (1897-1914): La confrérie senoussie et le commerce transsaharien, Paris.

Cleaveland, Timothy (1998). "Islam and the construction of social identity in ninenteenthcentury Africa," Journal of African History, xxix: 3, 365-88.

Cordell, Dennis (1977). "Eastern Libya, Wadai and the Sanūsìya: a țarīqa and a trade route", Journal of African History, xviii: 1, 21-36.

al-Dajjānī, Aḥmad Șidqī (1967 \& 1988). Al-Haraka al-Sanūsìya: Nash ${ }^{\top} a t u h \bar{a}$ wa-numūwuhā fi ' $l-$ qarn al-tāsic c ashar, Beirut.

Evans-Pritchard, E. E. (1949). The Sanūsī of Cyrenaica, Oxford.

Hamani, Djibo (1989). Au carrefour du Soudan et de la Berberie. Le sultanat Touareg de l'Ayar, Niamey.

Hofheinz, Albrecht (1996). “Internalising Islam. Shaykh Muhammad Majdhūb, scriptural Islam and local context in the early nineteenth-century Sudan". Ph.D., University of Bergen.

Hunwick, John (1992). "An introduction to the Tijani path: Being an annotated translation of the chapter headings of the Kitāb al-Rimāh of al-hājj 'Umar", Islam et Sociétés au Sud du Sahara 6, 17-32.

Ibrahim, Yahyā Muhammad (1993). Madrasat Ahmad b. Idrīs al-Maghribī, wa- atharuhā fi 'lSū $\overline{\bar{a}} n$, Beirut.

Insabato, Enrico (1920). L'Islam et la politique des alliés: L'Islam mystique et schismatique, Nancy.

Karrār, 'Alī Ṣalīh (1992a). Al-Ṭarīqa al-Idrīsīya fi ${ }^{\top} l-S \bar{u} d \bar{a} n$, Beirut.

- (1992b). The Sufi brotherhoods in the Sudan, London \& Evanston.

Lovejoy, Paul E. (1984). "Commercial sectors in the economy of the nineteenth-century Central Sudan: The trans-Saharan trade and the desert-side salt trade", African Economic History, xiii, 85-116. 
Martin, Bradford G. (1976). Muslim brotherhoods in nineteenth-century Africa, Cambridge, MA.

McDougall, Ann (1986). "The economics of Islam in the southern Sahara: The rise of the Kunta clan", Asian and African studies, xx: 1, 45-60.

- (1998). "Research in Saharan history", Journal of African History, xxix:3, 467-80.

O'Fahey, R.S. (1990). Enigmatic saint: Ahmad Ibn Idris and the Idrisisi tradition, London \& Evanston.

Peters, Emrys (1990). "The Sanūsī order and the Bedouin", in The Bedouin of Cyrenaica, Emrys Peters, Cambridge, 10-28.

Radtke, Bernd (1995). "Studies on the sources of the Kitāb Rimāh hizizb al-rahim of al-ḥājj "Umar", Sudanic Africa, 6, 73-113.

Radtke, Bernd, John O'Kane, Knut S. Vikør and R.S. O'Fahey (2000). The exoteric Ahmad Ibn Idrīs. A Sufi's critique of the Madhāhib and Wahhābīs, Leiden.

Rinn, Louis (1884). Marabouts et Khouan: Étude sur l'Islam en Algérie, Algiers.

Sedgwick, Mark (1998). "The heirs of Ahmad Ibn Idris. The spread and normalization of a Sufi order, 1799-1996". Ph.D., University of Bergen.

Shukrī, Muhammad Fu'ād (1948). Al-Sanūsīya, dìn wa-dawla, Cairo.

Slousch, Nahum (1906). "Les Senoussiya en Tripolitaine", Revue du monde Musulman, i, 2, 16982.

Triaud, Jean-Louis (1995). La légende noire de la Sanûsiyya: Une confrérie musulmane saharienne sous le regard français (1840-1930), Paris.

- (1987). Tchad 1900-1902. Une guerre franco-libyenne oubliée? Une confrérie musulmane, la Sanûsiyya face à la France, Paris.

Vikør, Knut S. (1995). Sufi and scholar on the desert edge: Muhammad b. ${ }^{c}$ Alì al-Sanūsi and his brotherhood, London \& Evanston.

- (1996a). Sources for Sanūisi studies, Bergen.

- (1996b) "Sufism and revolt. Tijānīs, Sanūsīs and Safavids", Paper, MESA Conference, Providence RI, 22-24.11.1996.

- (1999). The oasis of salt: The history of Kawar, a Saharan centre of salt production, Bergen.

- (2000). "Sufi brotherhoods," in The history of Islam in Africa, Athens, N. Levtzion and R. Pouwels (eds), OH, 441-76.

Ziyadeh, Nicola (1958 \& 1983). Sanūsīyah: A study of a revivalist movement in Islam, Leiden. 


\section{CHAPTER V \\ Sufi Leaders and Social Welfare}

Two Examples from Contemporary Sudan ${ }^{1}$

Rüdiger Seesemann

The following contribution deals with two issues. Firstly, it addresses the general question of Sufism and social welfare. Secondly, it situates the social welfare activities of Sufis in the political and economic context of contemporary Sudan and discusses the impact of Islamist rule on recent developments in the field of social welfare and praxis. The two issues are closely related to each other, because the social welfare activities of Sudanese Sufis are motivated both by religious aspirations and by the failure of the Islamic regime to respond to the social dilemma in the country.

To my knowledge, there are no comprehensive studies of Sufis and their involvement in social welfare. The focus of my research on the Tijāniya Sufi order and contemporary Islam in the Sudan was not on social welfare, and therefore the considerations in the present paper have a tentative character. They constitute a first step towards an argument on the social welfare initiatives of Sufis. More research is needed before final conclusions can be drawn.

The tentative character of the argument is also due to the fact that the material offered here essentially consists of only two examples of social welfare activities undertaken by Sufi leaders. These concern a shaykh of the Tijānīya Sufi order in Darfur (Western Sudan) and a shaykh of the Qādirīya order in Kadabas (Nile Valley). Due to the lack of documentation of other cases-which do certainly exist-there is no basis for comparison. But the examples of the two Sudanese shaykhs above clearly suggest that Sufis are indeed deeply involved in social welfare.

In order to place the two examples in a wider context, the paper begins with a discussion of the study of Sufism in more general terms. This is followed by a short description of contemporary political and economic developments in the Sudan with a focus on the situation in the field of social welfare. The concluding remarks constitute an attempt to interpret the social welfare activities of the two shaykhs.

\footnotetext{
${ }^{1}$ I would like to express my gratitude to the Deutsche Forschungsgemeinschaft for the funding of my research. I am also grateful to Kurt Beck and the participants of the Helsinki Workshop on "Social Justice, Social Welfare and Praxis in Islamic Societies in Africa" (Helsinki, April 23-24, 1999) for commenting on this paper.
} 


\section{Approaches to the Study of Sufism}

Evidently, the angle from which Sufism is viewed in the academic literature depends much on the specialisation of the respective author. A political scientist will turn his attention to power relations, an economist will focus on economic performance, a sociologist on social organisation, scholars of religious studies on theological dimensions and so forth. My concern is mainly with two other ways of studying Sufism (and Islam in general): the anthropological approach and the 'orientalist' approach. One of the principal differences between the two approaches is related to methodology. Anthropologists derive their understanding of Islam in general and Sufism in particular from the study of rituals and practices in a religious community, study which is usually based on research in a local context. 'Orientalists', on the other hand, obtain their perception of Islam and Sufism primarily through the study of texts. ${ }^{2}$

These two perspectives are reflected in the categories 'orthodox Islam' and 'popular Islam', the latter being the domain of the anthropologists, whereas the first is the field in which 'orientalists' are active. As a consequence, the 'orientalists' tend to draw an idealistic picture of their subject, just as it is depicted in the written sources. Their focus on the normative character of religion leads them to assume that the norms constitute reality. Whatever falls outside the realm of this reality does not belong to 'orthodox Islam', but has to be related to other, often external sources. In contrast, the anthropological view is inclined to see the existence of many Islams, because the findings of the anthropologists show significant differences in the practices of various Muslim communities. By putting the emphasis on Islam as practised, they acknowledge the contribution of individuals or groups to the process of translating texts into 'real life', but they ignore the fact that the world religion of Islam (and sometimes also the doctrine of a Sufi order) always remains the frame of reference in which the actors make their decisions and interpretations. Local practices of Muslims are thus considered in a way that isolates them from their doctrinal sources.

Apart from this criticism, both academic disciplines definitely have their strong points. But when it comes to certain questions, they might fail to provide complete answers. In the case of the 'orientalist' approach this applies especially to issues that are relevant in the everyday life of Muslims or to questions related to supposedly 'unorthodox' religious practices. As an example, one could cite the relationship between Islam, work and the work ethic. The 'orientalist' contributions to this topic are able to produce a catalogue of norms that is supposed to regulate the working practice and the organisation of labour. Yet the practical relevance of these norms is not con-

\footnotetext{
2 By using the term 'orientalists', I do not allude to the pejorative meaning attached to that term in the wake of the debate over Edward Said's famous book. Here, the term is rather used to characterise a specific methodological approach to the study of Islam.
} 
sidered at all. ${ }^{3}$ When anthropologists talk about Islam and the work ethic, they usually refer to the Senegalese Muridiya Sufi order which they view as a unique phenomenon. The idea that work can become a means of attaining salvation is seen as a departure from Islamic 'orthodoxy', and is presented as being limited to the case of the Muridinya. ${ }^{4}$ However, a closer look at the practices of other Sufi orders reveals that the principal concept of work is the same in various other Sufi contexts, too. ${ }^{5}$

It thus follows that there are elements of Sufism which escape the attention of 'orientalists', just as there are aspects which are neglected by anthropologists. The statement that the 'pious ideals' pursued by a Sufi order always have the 'primacy' over 'external' activities ${ }^{6}$ might be true from an 'orientalist' point of view, and it might even correspond to the self-perception of learned Sufis. But this perception is not necessarily shared by the 'ordinary' followers who might attach a different meaning to their Sufi identity. To describe the social, political or economic effects of Sufi orders as 'side-effects' of a primary purpose is to assume the existence of a single essence of Sufism which is, in fact, quite a problematic presupposition. It seems rather that the Sufis themselves do not divorce their involvement in the social, economic or political fields from their religious activities in the field of piety and of ideas. ${ }^{7}$ There might be a clear distinction between spiritual and temporal affairs, but the two are nevertheless closely related to each other. ${ }^{8}$ With few exceptions, Sufis have always actively participated in the development of the surrounding society, and sometimes they have even shaped the course of significant historical events-regardless of the fact that the literature produced by Sufi scholars does not contain explicit references to social or political activities. ${ }^{9}$ To study such activities is not to deny the importance of 'pious ideals' or the possible relevance of religious ideas for 'real life'.

This consideration finally takes us back to the issue of social welfare. Simply because Sufism lacks an ideology or doctrine that encourages or regulates social welfare activities it does not necessarily follow that Sufis do not

3 See Seesemann 1996, 141, and Beck 1996, 162-65.

4 For references see Seesemann 1996, 143.

5 For instance, the role assigned to work is very similar among the Tijānīya. For details see Seesemann 1996.

6 See the contribution of Knut Vikør (Chapter IV) in the present volume.

7 I do not share the opinion expressed by Vikør (Chapter IV) that the 'internal' or 'pious' side has to be seen as independent from the 'external', 'organisational' side. Those who read Vikør's contribution together with mine will notice the allusion to my paper as presenting the Sufi orders as social welfare organisations. I think from what I write it is clear that this is hardly my intention. The point I do make is that in order to find out what Sufis do in terms of social welfare, we have to study their practice and not only their writings. See also note 10 below.

8 The study of Islam, work and work ethic is a case in point. See Seesemann 1996.

${ }^{9}$ Certainly, there is no such thing in Sufism as a blueprint of how Sufis are supposed to pursue social or political affairs, nor do we find clear instructions of how social welfare activities are to be conducted. On the other hand, there usually is a clear and systematic concept of the mystical path. Therefore, neither involvement in politics nor social activity is an intrinsic feature that makes a Sufi a Sufi. 
engage in this field. Even without a doctrinal foundation, the lodge (zāwiya, pl. $z a w \bar{a} y \bar{a})$ as the basic unit of Sufi organisation can perform the function of a centre where social welfare services are offered. There are indeed many indications which support the view that the Sufis have played and continue to play a vital role in the promotion of social welfare ${ }^{10}$ - as a complement to (and not separate from) the promotion of piety and inner religious experience. The question of whether the social function performed by a Sufi order should be considered a by-product or side-effect of a 'primary purpose' or not is only of minor importance for the study of Sufism and social welfare. There may be no mention of social or economic activities in the doctrinal foundation of a Sufi order, but probably this absence has more to do with the character of the existing sources than with the actual non-involvement of the Sufis in the affairs of the wider society.

\section{War, Disaster, and Poverty as Challenges to Social Welfare in the Sudan}

Contemporary Sudanese society is characterised by extreme social, economic and ethnic divisions which have deepened as a consequence of the war in the South. The Southern regions are at present characterised by the total disruption of state structures and social security systems, whereas the Northern, Eastern and Western parts of the Sudan continue to suffer drought and famine. ${ }^{11}$ The tense situation is further aggravated by the unrelenting economic decline; indeed, in the cities as well as in the rural areas poverty has already reached alarming levels. ${ }^{12}$

Since the military coup of June 1989, the Sudan has been ruled by an Islamist regime. The government is certainly aware of the predicament that began to take shape in the early 1980s, but until now it has failed to respond to the immense problems in an appropriate manner. The continuing devaluation of the Sudanese Pound is but one indication of the failure of the regime's economic policy. The measures taken by the ruling Islamists to improve the living conditions of the Northern Muslim population are either ineffective or nothing more than simple propaganda. Even if there are programmes that aim to establish social services and health facilities, or to create new sources of income for the impoverished rural population, widespread

\footnotetext{
10 This is not to say that the role played by Sufis in social welfare activities can always be described in terms of a formal social security system. I will come back to the distinction between formal and informal systems of social welfare later (see below, in the section "Sufis and Sudanese Muslim society").

11 This article is not concerned with the population living in the South, nor does it discuss the situation of the so-called displaced people, i.e. the Southerners who took refuge in the Northern Sudan and number approximately four million. On the issue of displacement, see Eltigani 1995. The contributors to this volume also deal with the people from Eastern and Western Sudan who were displaced by drought.

12 See Ahmad \& El-Batthani 1995.
} 
corruption and lack of financial resources have prevented any significant change for the better. ${ }^{13}$

The Sudanese Islamists nevertheless continue to present their policy in terms of a 'civilisational project' based on 'authentic' Islam. The Islamist version of Islam as reflected in the idea of 'civilisation' shows a number of specific features that determine the approach to social welfare. A few remarks on the Islamist concept and practice of social welfare are necessary to provide the background to the Sufis' social activities that are discussed later.

\section{Islamist Rule and Social Welfare}

In the Sudan, Islamism serves not only as a religious ideology but the Sudanese protagonists of Islamism seek to translate the prescripts of Islam into political practice. The Islamic political universe as conceived by Hasan alTurābī and his associates consists of only two groups: committed Muslims who fight for the cause of Islam on the one hand, and the enemies of Islam on the other. This distinction is crucial, because it allows Islamists to blame the internal and external adversaries for virtually every social and economic problem the Sudanese are faced with. Thus, according to the Islamists, 'the West' is responsible for the underdevelopment of the country. Western policy is accused of trying to isolate the Sudan, just because the present government has opted for Islam as the only guideline of its policy. Furthermore, British colonial policy is said to have created the North-South division of the Sudan. Nowadays, neo-colonialism is identified as the new enemy which wants to accomplish the work started by the British by giving support to the Sudanese People's Liberation Army of John Garang.

Against the background of this scenario, the Islamist government draws a picture of an authentic Muslim nation of fighters standing against the forces of evil. This kind of struggle necessarily implies that the fighters are deprived of worldly pleasures. Renouncement is their principle in this life-the reward is waiting for them in the hereafter. This is the logic used by the Islamist rulers in the attempt to convince their subjects that they have to endure the hardships of everyday life and economic plight. As the Sudanese Islamists have decided to establish a truly Islamic state, they reject any foreign aid provided by non-Muslims. Instead, they preach an ideology of self-reliance and claim that the country's resources are sufficient to feed and clothe its people, as in the slogan na'kul min mā nazrac, nalbas min mā nașna ${ }^{c}$, which translates as "we eat what we sow, and we wear what we produce". However, the more cynically-inclined Sudanese often add to this slogan the phrase wanadhak min ma nasmac: "and we laugh at what we hear".

Considering it is a totalitarian regime that bases its legitimacy on religion, it does not come as a surprise that the Sudanese Government's propa-

13 According to El-Battahani, all these efforts had little impact on poverty alleviation. See further El-Battahani 1996, 19. 
ganda relies on religious arguments. The Governor of Northern Darfur publicly addressed the question of food shortage in the rural areas plagued by drought, first accusing 'the West' of having fabricated the news of famine in the Sudan, and then conveying the following message to those who still thought that there might not be enough food: "There is no food shortage, there is only shortage of faith". In other words, the truly faithful are supposed to be content with what they have, since it is God alone who decides whether there is food or not. The believers have to submit to divine judgement. According to the Qur'ān, God is the distributor of wealth (rizq), and thus every human being has to be grateful for the share of wealth allotted to him.

Yet, the emphasis put on this attitude by the present rulers of the Sudan does not mean that the solution to the problem of social justice offered by Islamism lies only in the simple acceptance of God's decision. In the Sudan as elsewhere, the leading Islamist ideologues like to dwell on the just nature of Islam and the equality of all believers before God. ${ }^{14}$ According to this view, Islam provides the blueprint for the perfect, just society, and it is the task of the small group of true believers to realise the lofty ideals of social justice, in their everyday life as well as in the projected Islamic state. The application of the $\operatorname{shari}^{c} a$ is believed to be the surest way to establish God's rule on earth, and whenever there is injustice, the Muslims are urged to rush to the support of their fellow Muslims.

However, contrary to the claims of the Islamists, the application of the $\operatorname{shari}^{c} a$ in the Sudan did not automatically lead to the prevailing of social justice. With regard to social welfare, the government-sponsored measures are almost exclusively concerned with the mujähid $\bar{u} n$ who fight in the 'Holy War' in Southern Sudan, or with the families of the so-called martyrs who died on the battlefields. ${ }^{15}$ The revenue collected by the government in the name of $z a k \bar{a} t$ is for the most part used for the jihād; the rest is either absorbed by the administration or by corruption. ${ }^{16}$ Clearly, Islamists make use of their social welfare activities in order to further their personal, political and even military goals. The same seems to be true of two Islamic non-government organisations that operate in the Sudan, namely the Islamic African Relief Agency and the Munazzamat al-Dac wa al-Islāmìya. In fact, the welfare and relief programs run by these organisations appear to be no more than a cover for their proselytising activities. ${ }^{17}$

\footnotetext{
14 A prominent example is the Egyptian Islamist thinker Sayyid Qutb whose book al- ${ }^{c}$ Adāla al-

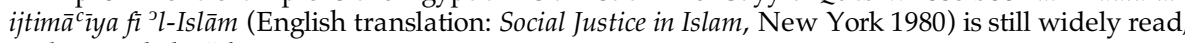
and not only by Islamists.

15 Examples are the organisation Z Zăd al-mujāhid which is concerned with allocating funds for the fighters and the Munazzamat umm al-shahid which gives financial and material support to the mothers of martyrs.

16 On the inefficiency of the present zakāt practice, see El-Battahani 1996, 19.

17 Bellion-Jourdan 1997.
} 
Elsewhere, particularly in Egypt, Islamists do enjoy a certain popularity among the Muslim population on account of their social welfare programs. ${ }^{18}$ Although they are in power in the Sudan, they offer nothing but empty rhetoric. The almost total failure of the Islamist government in responding to the needs of the Sudanese population comes as a challenge to the existing social and religious forces.

\section{Sufis and Sudanese Muslim Society}

There is no need to stress the importance of Sufi orders in the Sudan. This has already been done by a number of authors since the colonial period. ${ }^{19}$ In their works, much attention has been paid to the political involvement of Sufi leaders. Several studies have also dealt with the religious dimensions of Sufism in the Sudan, and we are relatively well informed about the educational activities of the Sufi orders. However, when it comes to the question of social welfare, there are only a few scattered remarks that acknowledge the involvement of Sufis in this domain.

Many studies have pointed to the fact that the Qur'annic school, known as khalwa and in many cases directed by Sufis, is not only about memorising the word of God. ${ }^{20}$ In addition to this immediate task, the khalwa also fulfils several social functions: It may serve as a rest house for visitors and travellers, as a refuge or sanctuary, and as a place for settling disputes. The head of the khalwa, usually called faki in the Sudan, performs a great variety of tasks, ranging from the writing of amulets to the medical treatment of people suffering from both physical or mental diseases. ${ }^{21}$

Historical sources as well as contemporary accounts indicate that similar services have been and continue to be offered by the zawāy $\bar{a}$, the religious centres of the Sufi orders. ${ }^{22}$ The multiple functions performed by institutions linked to the Sufi orders such as the khalwa and the zāwiya account for the significant role played by these orders as informal social security systems. A comprehensive study of the issue might even show that the appeal of the Sufi orders also stems from the fact that the shaykhs were not only concerned with spiritual welfare, but also with social welfare and the material needs of the Muslim community. In addition, for the followers of the Sufi orders, worldly success depends on the blessings provided by the shaykhs-this can be taken as a further indication of the connection between the spiritual sphere and

\footnotetext{
18 See Rieger 1996.

19 To mention only some of those who wrote in English or French: Trimingham 1949, Voll 1969 and Voll 1992, Grandin 1989, Bleuchot 1996, Karrar 1992, O’Fahey 1993, and al-Karsani 1985. Another very rich study is Hofheinz 1996.

20 See for instance Karrar 1992, 137-44 and Seesemann 1995, 100. One of the few studies that deal with the non-educational aspects of the khalwa is Abdel-Galil 1974

21 For a detailed description of the fakis activities, see El-Tom 1983, 59-111.

22 This is well documented in the academic literature on the Sufi orders. See for instance Garcin 1996.
} 
material matters. The believers visit a Sufi shaykh because of the latter's material and spiritual capacities. Neither the material not the spiritual side of this relationship is necessarily formalised; the exact contents and the form of the interaction between the shaykh and his followers may indeed vary from case to case and over time.

However, the purpose of the present article is not to give a detailed description of the informal social welfare services 'traditionally' offered by Sufi orders. ${ }^{23}$ If we take the close relations of the Sufis with the surrounding society for granted, the questions arises of how they respond to a crisis situation such as that in contemporary Sudan. Is the 'traditional' system of social security as embodied in the khalwa and the zäwiya capable of contributing to the solution of problems caused by 'modern' circumstances? Can the Sufi shaykhs offer more than spiritual support to those who have to cope with economic hardships, drought and disaster? In the following, I will present two Sudanese Sufi leaders who have taken the initiative in finding practical solutions for the social dilemma in contemporary Sudan.

\section{Shaykh Ibrāhīm Sīdī and His Program of Social Rehabilitation for Street Children}

The first case study concerns a program of social rehabilitation for problem and street children that is run by a leader of the Tijāniya Sufi order in the town of El Fasher, the capital of Northern Darfur Province. ${ }^{24}$ Shaykh Ibrāhīm Sīdī, the initiator of this project, was one of my informants during the research I conducted in Darfur in 1994 and $1995 .{ }^{25}$ In addition to the conversations I had with him about his social welfare activities, the following information is also drawn from a short treatise written by shaykh Ibrāhīm Sīdī in 1989, entitled "My experience with the youth: Meeting the challenge" ${ }^{26}$

Ibrāhīm Sīdī's career as a Sufi shaykh started in the late 1970s when he decided to quit his job as a teacher in order to dedicate himself solely to the promotion of the Tijānīya order. In 1979, he opened his zāwiya at the Tijānīya quarter in El Fasher, next to the mosque erected by his late father Sīdi Muhammad in the early 1950s. Shortly thereafter shaykh Ibrāhīm Sīdī took charge of the neighbouring Qur'ānic school which had already existed before the establishment of the mosque. Together with his elder brother Muhammad

23 In fact, such a task would require thorough research and, more importantly, a clear definition of what is to be understood by such terms as 'social security' and 'traditional'.

24 According to the 1993 census, El Fasher had slightly more than 140,000 inhabitants. The rapid population increase is evident when this number is compared to the estimated population of 45,000 in 1977.

25 Results of this research are presented in Seesemann 1996 and Seesemann 2000.

26 Ibrāhīm Sīdī, Tajrubatī $m^{c} a$ 'l-ahdāth al-tașaddī wa ' l-tahaddī, 1989. He wrote this 5-page account in order to distribute it to government officials and interested individuals. It is not published. Shaykh Ibrāhim died in September 1999, a few months after this article was written. For a more recent assessment of his life and his writings, see Seesemann (forthcoming). 
al-Ghālī, shaykh Ibrāhīm Sīdī later designed a reform program for the khalwa which they called iṣlăh al-ahdāth, social rehabilitation of the youth. In doing this, they intended "to react to the challenges posed by the contemporary social conditions". ${ }^{27}$ The Qur'ānic school was supposed to offer "a noble alternative to the youth" 28 who are homeless or led astray by alcohol and drug addiction.

Indeed, one of the most striking features of Sudanese towns is the omnipresence of boys, most of them aged between 6 and 18 years, who beg and hang around in the streets. This phenomenon is called tasharrud, i.e. vagabondage, and the boys are commonly known as shammāsha, a term derived from shams, the Arabic word for 'sun', being an allusion to the fact that the children do not have a roof over their heads. In the cities of the Central Sudan, many are Southerners, but in the Western Sudan, the majority of the boys are either from the countryside or are urban school drop-outs, with a low proportion of Southerners. ${ }^{29}$

The boys are commonly said to be drug addicts; in particular, the practice of sniffing glue or solvents is attributed to them. Other drugs, such as

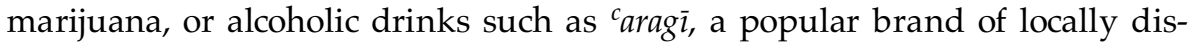
tilled spirits, are too expensive to be consumed by the shammāsha on a regular basis.

According to shaykh Ibrāhīm, the shammāsha only appeared in the 1980s. He relates their increased presence in public areas to the "pernicious atmosphere of modern cities" and puts the blame on the "modern style of education" which fails to provide the children with the morals and spiritual values of Islam. ${ }^{30}$ The lack of religious orientation has led to the emergence of a "culture of libertinism" that has shaken the very basis of society. ${ }^{31}$ In addition, the diffusion of modern mass media such as television and video has facilitated access to Western movies that undermine the values of Islam.

However, shaykh Ibrāhīm believes that the invasion by this foreign civilisation would probably not have succeeded on such a large scale, were it not for the simultaneous weakening of local society caused by the drought that hit the Sudan in the early 1980s. Indeed, in the wake of environmental degradation, rural-urban migration reached new levels and brought thousands of newcomers to the towns of Northern Darfur. According to shaykh Ibrāhīm Sìdi's interpretation, this development undermined the cohesion of families. Family members were dispersed, and the fathers who were either absent or

\footnotetext{
27 Sīdī 1989, 1.

28 Ibid.

29 To my knowledge, statistical data on the shammāsha is not available. It is difficult to say anything definite about their numbers and their areas of origin. There are reports by UNICEF, ILO and CARE on street children but these address mainly the situation of the 'displaced people' in the cities of the Central Sudan.

30 Sīdī 1989, 2.

31 Ibid.
} 
occupied with finding a way to feed their families lost authority over their sons. As a consequence, the youth deviated from the right path: they ceased going to school and started stealing, they used drugs and had illicit sexual relations. As for the fathers, they often turned away from their sons, unable to find a solution to the problem. These are the boys who constitute the target group of shaykh Ibrāhīm Sīdì's social welfare activities.

The Qur'anic school is at the core of the rehabilitation program designed by shaykh Ibrāhim, as he believes that the indispensable prerequisite for the building of a just and virtuous society lies in the sound religious education of its members. Since the early 1980s, the program has evolved gradually from the occasional admission of shammāsha into the khalwa. They usually lived as boarders in the Qur'annic school, together with other boys who had left their families in order to pursue their religious studies. In addition to the boarders, the children of the neighbourhood attended the lessons in the early morning and in the afternoon.

Directed by shaykh Ibrāhīm Sīdī and his brother Muhammad al-Ghālì, the khalwa in the Tijāniya quarter soon became very popular. Within a short period of time, it gained a reputation for dealing with problem children in an effective way. Subsequently, fathers came from all over Darfur to get their sons admitted into the Quraanic school. During the first years of the shammāsha's presence in the khalwa, their training did not differ from the one given to the other children. But by 1987, when the problem children outnumbered the ordinary disciples for the first time, shaykh Ibrāhīm and Muhammad al-Ghāli took action in order to respond to their particular needs.

The shammāsha can easily be distinguished from the ordinary disciples, because they are put in chains as soon as they are admitted to the khalwa. ${ }^{32}$ This measure is only taken with the prior consent of the father or legal guardian, but it is considered necessary by shaykh Ibrāhīm in order to prevent the boys from running away at the first opportunity. In addition, those children who are suspected of drug addiction are kept in isolation from the others, and their relatives can only visit them after being searched. On a regular basis, a doctor checks the physical condition of the boys. In the first phase after their arrival, most of the shammāsha are reluctant to stay at the Qur’annic school or to attend lessons. But sooner or later the moment comes when their will is broken. They give up their resistance and start to join the other children, gradually integrating themselves into the life of the khalwa. They are not yet required to memorise the Qurān, and some of them spend weeks just listening to the others. Shaykh Ibrāhim Sīdì is confident that the new environment does have a positive effect on the boys, as he expresses in the

\footnotetext{
32 There are even different kinds of chains: newcomers usually start with very restrictive ones, and later they get slacker ones as a result of good conduct. But disobedience can always be punished by tightening the chains, and the most severe set of chains makes it impossible for the offender to move. Each kind of chain is known by a particular name. Similar methods of punishment for disobedient students continue to be applied in quite a few Qur ānic schools in subSaharan Africa.
} 
statement: "The first step is to keep them away from the evil, the second step is to take them to the good". 33

To shaykh Ibrāhīm Sīdīi, the 'good' is the correct Islamic practice that begins with the daily performance of the five prayers and the memorisation of the Qurcān. As soon as the shammāsha participate fully in the khalwa routine, they are released from the chains. But shaykh Ibrāhim sees that additional measures are required in order to prevent the boys from relapsing into drug addiction or committing petty offences after their release from khalwa. He maintains that "necessity is not only the mother of invention, but also the mother of deviation", 34 and is thus convinced that the only long-term solution for the shammāsha lies in providing them with school education or vocational training. On the basis of this consideration, shaykh Ibrāhīm Sīdī has decided to establish a school especially for problem children and to offer them a vocational training program.

In 1987, the program started with the establishment of a butcher's and a workshop for construction workers. The first building project was a dormitory that was intended to accommodate the boys who lived in the khalwa. The municipal authorities of El Fasher later approved the construction of three classrooms and an office for the teachers of the projected Complementary School. Next to the school, which started to operate in 1989 with the official permission of the Ministry of Education, the boys constructed a small health centre and a shop that was run on a co-operative basis. By the end of 1989, there were more than 170 children staying as boarders in the Qurānic school, and the proportion of the shammāsha had reached almost 70 per cent.

In its first year, the Complementary School was run with one class of 30 boys, most of them former school drop-outs with learning difficulties. The curriculum extended over two years and was designed by the director Muhammad al-Ghālī who was assisted by one teacher. The children were taught reading, writing, history, mathematics and science, with the objective of helping them catch up with the standard in public schools. In the following period, the Complementary School expanded annually and finally comprised four classes. In order to feed the increasing number of boarding students, shaykh Ibrāhīm Sīdī successfully applied for support from the United Nations' World Food Program. The khalwa and the Complementary School regularly received food donations, usually in the form of wheat. The shaykh then bought a generator and a grain mill, thus ensuring the food supply for the continuously growing number of children.

In a next step, shaykh Ibrāhim set up three more workshops to teach the shammāsha the basics of carpentry, car repairing and the production of metal goods. The instruction was carried out by followers of the shaykh who lived with him in the zāwiya. At a later stage, they were aided by those boys who already had acquired some experience in their respective fields. The material

33 Sīdī 1989, 3.

34 Ibid. 
required for running the workshops came from donations or was bought by shaykh Ibrāhīm Sīdī himself. The vocational training was free of charge, as was the Complementary School. The only revenue that came to the khalwa from the families of the children is small amounts of money paid to the heads of the Qurānic schools according to the tradition of Darfur. The products manufactured by the boys in the carpentry and metal workshops, such as chairs and tables, were either used in the Complementary School or sold at the market.

Another remarkable feature of shaykh Ibrāhīm Sīdī's rehabilitation program was the emphasis put on encouraging the creative capacities of the problem children. The shaykh explicitly says that he wants to impart an "aesthetic sense" 35 to the boys, a task he tries to accomplish by supplying them with musical instruments, sheets of paper and coloured pencils. In addition, he encouraged them to form small theatre groups where they can perform their own sketches. From time to time, these sketches were presented in the khalwa or the neighbouring Complementary School on the occasion of public celebrations. Moreover, regular meetings were held by shaykh Ibrāhīm and Muhammad al-Ghālī with the shammāsha in order to give them the opportunity to talk about their personal experiences and concerns.

The standard duration of stay in the Quraanic school was fixed at three years for the problem children who participated in the rehabilitation program. According to shaykh Ibrāhīm Sīdī, this is the period required for the measures undertaken to have a profound influence and a lasting effect on the shammāsha. For the other boys, the duration of their stay depends on how they proceed in their religious studies. Those who intend to learn the whole Qur'ann by heart spend up to five years in the khalwa, but most children leave as soon as they have obtained some basic knowledge of Islam and its Holy Book.

In 1994, Muhammad al-Ghāli made the pilgrimage to Mecca. As there was nobody to stay in charge of the khalwa during his absence, all the children were sent home and the school was closed. After his return from the Hijāz, Muhammad al-Ghālī was not able to reopen the boarding school due to lack of funds and material resources. Since that time, only children who live in the neighbouring quarters of El Fasher are admitted to the Complementary School, and the khalwa operates exclusively for those who come to memorise the Qur’ān in the early morning and in the afternoon. During my stay in El Fasher, I witnessed only one single person in chains there.

Nevertheless, the statistics compiled by Muhammad al-Ghālī are impressive. They show that more than 2,200 children were admitted to the khalwa as boarders between 1980 and 1994. 500 boys classified as 'deviated' passed through the rehabilitation program that started in 1987. According to shaykh Ibrāhīm, most of the shammāsha have not returned to life on the streets. Although it is difficult to verify this statement, I am inclined to believe that it is true. In the course of my research that extended over 15 months, I frequently

35 Ibid. 
met young men in different places who told me that they had stayed at the khalwa of shaykh Ibrāhīm Sīdī. When I asked them to describe their experience with the shaykh, almost all of them expressed their gratitude to shaykh Ibrāhīm Sīdī and Muhammad al-Ghālì. They readily admitted that the rehabilitation program enabled them to change their lives, and some have even found jobs on the basis of what they had learned in the vocational training. In general, shaykh Ibrāhīm enjoys a great popularity among the youth of El Fasher.

What are the motives behind shaykh Ibrāhīm Sīdī's initiative? As mentioned above, the shaykh sees his effort as a response to the spread of immorality that threatens Islamic society. In his booklet "My experience with the youth", he gives a number of quotations from the Qurān and the hadith to explain why he decided to take action. Islam, shaykh Ibrāhīm Sīdī states, is an active and dynamic religion designed to be applicable to everyday life. It exhorts the believer to lead an exemplary life according to the rules of the Qur'ann and the Sunna. But the Qur’ann not only lays down the guidelines for individual behaviour-moreover, it includes a comprehensive constitution for society as a whole. In this capacity, the Qurān offers the perfect solution for every problem. Thus, a return to religious roots can provide the proper remedy to cure all kinds of deviation and social malady. ${ }^{36}$

The central role assigned to the Qur àn in saving the Muslim umma from evil explains why the methods applied by shaykh Ibrāhim in his work with the boys concentrate on the memorisation of the Qur'ān. In this respect, the method does clearly relate to the Islamic tradition of education and learning as practised in Darfur for centuries. ${ }^{37}$ In the perception of the Muslim population of Darfur, memorising the Qurān has always been a precondition for the well-being of the people and the functioning of their society. From that perspective, shaykh Ibrāhīm Sīdī's approach is derived from a 'traditional' concept of social welfare. And indeed, putting children in chains does seem to be a rather archaic technique for social rehabilitation.

What renders this case exceptional is the innovative approach taken by shaykh Ibrāhīm Sìdī in responding to the specific situation of the street children. Contrary to the ruling Islamists who give the impression that the invocation of the $\operatorname{shari}^{c} a$ will release the Sudanese from their suffering, shaykh Ibrāhīm does not stop at preaching the healing powers of compliance with the prescripts of Islam. Apart from spiritual assistance, shaykh Ibrāhīm Sīdī's

\footnotetext{
36 In the words of shaykh Ibrāhīm Sīdī: "In teaching and memorising the Qurān, and in living according to its rules, the Muslims have always found the best and most exalted model of society. That is why the Muslims have been concerned with learning and teaching the Qur ān since the days of the Prophet Muhammad, and will be up to the day when God inherits the earth" (Sīdī 1989, 1).

37 I have described this tradition of learning in two papers on Qurāanic schools and Islamic education in Darfur (Seesemann 1995 and Seesemann 1999).
} 
rehabilitation program offers practical solutions to the problems of the shammāsha. The objective is to help them become integrated into a modernising urban society.

At this juncture it is interesting to note that the religious justification given by shaykh Ibrāhīm Sīdī is coupled with humanitarian considerations. The shaykh's decision to take care of the street boys was not only motivated by his wish to fight against immorality-he also borrows from the rhetoric of humanitarian aid by presenting his work for the youth as a contribution to the world wide fight against drug addiction and as a part of the struggle for a better future on the planet. Actually, the commitment to humanitarian principles in his approach is reflected in the transformation of the khalwa into a vocational training centre. At the same time, shaykh Ibrāhim Sīdi tried to improve his agenda by adopting modern educational concepts such as stimulating the creativity and imagination of the boys by means of music, theatre and arts.

\section{Shaykh al-Ja ${ }^{c}$ ali and the Charity Hospital at Kadabas}

The second case I would like to present deals with the Charity Hospital established in 1997 by shaykh al-Häjj Hamad Muhammad al-Jacalī, a leader of the Qādirìya Sufi order in Kadabas in the region of Berber. Although the example of this hospital shows some differences from the case of shaykh Ibrāhīm Sìdī, both examples have in common that they do not simply constitute a continuation of informal social security systems, but are 'modern' responses to contemporary problems. The formal character of the hospital project is indicated by the fact that it was undertaken by an association founded especially for the purpose of promoting social welfare: the 'Shaykh al-Ja'ali Charity Society' (Jam 'ìyat al-shaykh al-Jacalì al-khayrīya). ${ }^{38}$

Since the mid-nineteenth century, Kadabas has had a high reputation as a religious centre. ${ }^{39} \mathrm{Ahmad}$ al-Jacalī, the founder of Kadabas, was initiated into the Qādiriya order in the 1860s, and after his death the zāwiya continued to be maintained by his descendants. In recent decades, the fame of Kadabas rested on the leadership of shaykh al-Hâjj Hamad Muhammad al-Jacalī, the initiator of the charity association, who died in 1998. Apart from the esteem he enjoyed for being the head of a well-known centre of religious learning, his own celebrity stems from his activities as a 'traditional' healer. In fact, during the lifetime of shaykh al-Ja a alī, Kadabas was the destination of an incessant stream of visitors who came to seek a cure for their illnesses or simply to receive his blessing (baraka). By providing his followers with amulets, special medical treatments

\footnotetext{
38 The following account of the hospital essentially relies on the presentation given in a small booklet published by the Jam ${ }^{c} \bar{y} y a t$ al-shaykh al-Jac ali al-khayrìya in 1997 under the title entitled Mustashfā Kadabās al-khayrī ("Kadabas Charity Hospital").

39 See Karrar 1992, 34-35. Details on the religious activities and the educational institutions at Kadabas are given in Mustashfā Kadab̄̄s al-khayrī, 7-8.
} 
('azìma), baraka and supplicatory prayers, shaykh al-Jacali offered the services that are considered to be the 'traditional' tasks of holy men in the Sudan.

As in other religious centres on the Nile, the core institution at Kadabas is the Qur'ānic school which has operated since the days of Ahmad al-Ja'alī. The memorisation of the Qur'ān is complemented by the so-called 'circles' (halaqāt) and 'assemblies' (majālis) where the students can improve their knowledge of the Islamic sciences. In the eyes of the followers of shaykh al-Haijj Hamad Muhammad al-Jacali, the significance of these activities transcends the purely religious sphere and extends to society as a whole: "The people in and around Kadabas are illuminated by the light that emanates from the Qur ânic schools, and they drink from the sources of knowledge that flow from the majālis." 40 This perspective implies that the mere existence of a religious centre contributes to the well-being of the whole region and its inhabitants. The same notion is explicitly expressed in the following statement: "From the religious role played by Kadabas emerges its social role." 41

The members of the executive board of the hospital project maintain that the social role of Kadabas and the activities in the field of religious education almost automatically entailed a concern with public health. ${ }^{42}$ The idea came from the late shaykh al-Hājj Hamad Muhammad al-Jacalī himself. The story goes that, during a meeting with several of his followers, he suggested that they should build a hospital. What initially appeared to them as an impossible to realise project was finally achieved through the hard and assiduous work and the firm belief of the inhabitants of Kadabas and its surrounding villages.

In the beginning the approval of the regional authorities was needed in order to start the project. The response was positive, though the shaykh was told that his people had to build and equip the hospital as a self-help initiative because the government was not in a position to offer any financial assistance. Much of the work was done in communal labour (nafir), and those who participated in the construction did not receive wages, "except the reward they get from God". ${ }^{43}$ The people are said to have been enthusiastic in their participation:

Then came the delegations from the villages, towns and tribes and they started to compete with each other in this great charitable work. They transformed the place into a beehive (...), totally committed to their work for God's cause. The delegations brought with them everything they needed: Food, drinking water and even the firewood for baking the bricks (...). Through the grace of God, the buildings were soon completed, and their greatness and gigantic proportions confirm that the hand of God was with the community. 44

40 Mustashfā Kadabās al-khayrī, 7.

41 Ibid., 8. As examples of the social role the text mentions the judicial function of Kadabas and the successful efforts to reconcile feuding tribal groups or individuals.

42 Ibid.

43 Ibid., 11.

44 Ibid. 
Apart from the labour and the construction material provided by the local people, the hospital project depended on donations from wealthy Sudanese migrants to Saudi Arabia and the Gulf states. In addition, the Saudi government participated in the funding of the hospital equipment and the medical instruments. At present, the hospital runs with departments for surgery, internal medicine, gynaecology, and neurology; it also has a children's clinic and an eye clinic. It is designed for 200 in-patients, and the annual budget amounts to almost 300,000 US Dollars. More than 50 per cent of the capital comes from private donations and from social welfare organisations based outside the Sudan; the remaining income consists mainly of treatment fees paid by the patients. However, medical treatment is free for those who made financial contributions to the hospital during the construction phase. This underlines the self-help character of the project. With its modern equipment, the clinic is among the best hospitals in the area of Berber.

The social welfare activities of the 'Shaykh al-Jacali Charity Society' certainly constitute an exceptional case in the Sudanese context. ${ }^{45}$ At least two features have to be seen as peculiar to the hospital project. Firstly, it was undertaken by a formal organisation founded for the promotion of social welfare, and secondly, its large scale. Nevertheless, as in the case of Ibrāhìm Sīdì's youth rehabilitation project that evolved out of the 'traditional' social role of the Qur'ānic school, the hospital can be viewed as an extension of the 'traditional' medical services offered by shaykh al-Hājj Hamad Muhammad al-Jacalī. Whereas the 'traditional' methods of healing and care are applied in an informal context, the hospital provides a formal framework for medical treatment. Of course, this shift from the informal to the formal sphere also implies a shift in the choice of methods: the hospital offers modern medicine, whereas the 'traditional' way of dealing with sickness relies on the magical power of the fakī. Although shaykh al-Ja'ali was well-known as an effective 'traditional' healer, he seems to have also embraced the advantages of modern medicine.

As mentioned above, the followers of shaykh al-Jacali see their initiative for the promotion of public health as an extension of their religious and social activities. A closer look at the booklet Mustashfā Kadabās al-khayrī reveals further information regarding the motives for their commitment to the charitable cause: the members of the hospital's executive committee identify themselves with the group of believers described in the hadith: "God has chosen some of his servants for the task of responding to the needs of the people. He loves them for their good deeds, and He endows them with His

45 I do not know of any similar initiative in the Sudan. There are, however, formal charitable organisations founded by Sufis in Nigeria and Senegal. In the Senegalese town of Kaolack, shaykh Hasan Cissé, an internationally known leader of the Tijāniya order, established a hospital in 1998. 
grace. They are secure from God's punishment on the Day of Judgement" ${ }^{46}$ This kind of charitable work is supposed to be done for God alone (li-wajh Allāh) and with a pure intention (ikhlās). Provided that these two conditions are fulfilled, everybody who participated in the construction of the hospital will get his reward in the Hereafter. ${ }^{47}$

This notion of social welfare does not contain ideas that can be described as peculiar to Sufi doctrine. This rather corresponds to the general concept of Islamic ethics which is based on the principle of reward and punishment. But in view of the lack of efficient health services the followers of shaykh al-Jacali do not simply submit to their fate. As in the case of shaykh Ibrāhìm Sìdī's rehabilitation program, the Qādirī Sufis of Kadabas take the initiative and try to put the ethical commands of Islam into practice. This distinguishes them from the ruling Islamists whose activities hardly go beyond empty words. Moreover, the example of Kadabas Charity Hospital also shows how Sufis are capable of responding to 'modern' crisis situations by extending their 'traditional' sphere of activity.

\section{Conclusion}

By way of conclusion, I would like to consider the social welfare activities of shaykh Ibrāhīm Sìdī and shaykh al-Jacalī in the light of the two general issues raised in the introduction.

With regard to the question of Sufism and social welfare, the social dimension of the khalwa as represented in the case of shaykh Ibrāhīm Sīdī and the medical services offered by shaykh al-Jacalì clearly show that at least in these two cases, the Sufi orders do not function only as religious organisations in the narrow sense. They are concerned with the spiritual as well as with the material needs of the followers. ${ }^{48}$ Of course, the suggested possibility of viewing the institutions run by Sufi orders as 'traditional' social security systems needs to be substantiated by future research. Only a better understanding of the zâwiya and the khalwa as arenas in which social interaction takes place would allow us to assess the impact Sufis have on social welfare.

In addition, both shaykhs have initiated social welfare projects that can be described in terms of a formalisation of informal social security systems as represented by the Qur'ānic school and 'traditional' healing methods. The youth rehabilitation program and the hospital in Kadabas both show the characteristics of formal institutions. In that sense, the activities of shaykh

46 Mustashfā Kababās al-khayrī, 14.

47 The authors of the booklet express their confidence in the coming recompense in the words of a prayer: "May God weigh the work done for His cause on the scale of the good deeds, for all those who were dripping with sweat and who have contributed their ideas or their money to the accomplishment of the hospital." (Mustashfā Kadabās al-khayrī, 11.)

48 Hence, I do agree with Vikør's statement (see Chapter IV) that we should try to see how the pious ideals and the social practice are integrated. 
Ibrāhīm Sīdī and shaykh al-Ja ${ }^{c}$ ali exceed the range of the social security system as traditionally practised by the Sufis. ${ }^{49}$ Thus, the two Sudanese shaykhs provide examples of Sufi leaders whose social welfare activities can be classified as belonging to the sphere of 'modern' social security systems. This can be taken as an indication of the capacity of the Sufi orders to react to 'modern' challenges. Formal social welfare initiatives can therefore be viewed as a part of the transformation of the Sufi orders that has occurred in recent decades.

However, this process of formalisation or modernisation is not the outcome of a specific Sufi approach to social welfare. As mentioned above, reference is made to Islamic ethics and not to a particular Sufi doctrine. Hence it is the actual performance rather than the doctrine that allows us to identify the Sufis as actors in the field of social welfare. This also explains why the 'orientalist' approach must fail to recognise the role Sufis play in social welfare: the study of texts and ideas cannot provide us with an understanding of the social significance of the Sufi orders. Texts will tell us even less about the ongoing transformation of the Sufi orders.

A final consideration of the possible reasons for the formalisation of social welfare activities brings us back to the second issue, namely the impact of Islamist rule on the development of social welfare in the Sudan. What is striking about the current situation in the Sudan is the non-existence of efficient social welfare programs directed by the government-sponsored Islamist organisations, apart from the activities which serve the jihād in the South. The government does almost nothing to improve the precarious situation of most Sudanese. The vacuum created by the ruling Islamists is filled by informal social security systems, but it also leads to the rise of more formalised social welfare initiatives. These circumstances give the Sufi orders the opportunity to act as grassroots organisations-in just the same way as Islamist movements do in other countries. Interestingly, in both cases it appears that those groups who are opposed to a failing regime can take advantage by carrying out social welfare programs.

The overall crisis and the social dilemma constitute the background for the formalisation of 'traditional' social welfare structures. The shift from 'traditional' to 'modern' social security systems as represented in the cases of shaykh Ibrāhīm Sīdī and shaykh al-Jacalî is aided by the failure of Islamist social and economic policies. Therefore, Islamist rule unintentionally seems to have accelerated the transformation process of the Sufi orders in the Sudan.

\footnotetext{
49 A remark by al-Tayyib Muhammad al-Ṭayyib, an expert on Qurānic schools and higher Islamic education in the Sudan, confirms that the khalwa run by shaykh Ibrāhīm Sīdī does not follow the 'traditional' Sudanese pattern. According to al-Ṭayyib, the rehabilitation project for street children makes the khalwa "a real model of the connection of education with work" (rabt al-tac ${ }^{c} \bar{i} m$ bi ${ }^{\top}$ - $^{c}$ amal; al-Ṭayyib 1991, 233).
} 


\section{Bibliography}

Abdel-Galil, Musa Adam (1974). Some political and economic aspects of Koranic Schools in Jebel Si. B.Sc. dissertation, Department of Social Anthropology, University of Khartoum.

Ahmad, Adil Mustafa \& Ata El-Hassan El-Batthani (1995). “Poverty in Khartoum”, Environment and Urbanization, 7, 195-206.

Beck, Kurt (1996). "Islam, Arbeitsethik, Lebensfūhrung”, in Arbeit in Afrika, Kurt Beck/Gerd Spittler (eds), Hamburg, 161-78.

Bellion-Jourdan, Jérôme (1997). “L'humanitaire et l'islamisme soudanais. Les organisations $\mathrm{Da}^{\mathrm{c}}$ wa Islamiyya et Islamic Relief Agency", Politique Africaine, 66, 61-73.

Bleuchot, Hervé (1996). "Les confréries religieuses et leurs partis au Soudan: évolution ou mutation?" in Les institutions traditionnelles dans le monde arabe, Hervé Bleuchot (ed.), Paris, 159-71.

El-Battahani, Atta (1996). "The social and political impact of economic liberalization and social welfare in Sudan", Working Paper 6/96, Institute of Development Studies, University of Helsinki.

Eltigani, Eltigani E. (ed.) (1995). War and drought in Sudan. Essays on population displacement, Gainesville.

El-Tom, Abdullahi Osman (1983). Religious men and literacy in Berti society. Ph.D. thesis, St. Andrews University Edinburgh.

Garcin, Jean Claude (1996). "Assises matérielles et rôle économique des ordres soufis", in, Les voies d'Allah, Alexandre Popovic/Gilles Veinstein (eds), Paris, 213-23.

Grandin, Nicole (1989). "Traditions religieuses et politiques au Soudan contemporain", in Le Soudan contemporain. De l'invasion turco-égyptienne à la rébellion africaine (1821-1989), Marc Lavergne (ed.), Paris, 227-70.

Hofheinz, Albrecht (1996). Internalising Islam. Shaykh Muhammad Majdhūb, scriptural Islam and local context in early 19th-century Sudan. Ph.D. thesis, University of Bergen.

Jamīyat al-shaykh al-Jacalì al-khayrīya (1997). Mustashfā Kadabās al-khayrī ("Kadabas Charity Hospital"). N.p. [Khartoum].

Karrar, Ali Salih (1992). The Sufi brotherhoods in the Sudan, London.

al-Karsani, Awad al-Sid (1985). The Tijaniyya order in Western Sudan. A case study of Khursi, AnNahud and Al-Fasher. Ph.D. thesis, University of Khartoum.

O'Fahey, Rex Sean (1993). "Islamic hegemonies in the Sudan: Sufism, Mahdism, and Islamism," in Muslim Identity and Social Change in Sub-Saharan Africa, Louis Brenner (ed.), Bloomington, $21-35$.

Rieger, Brigitte (1996). Überleben ohne Staat: soziale Sicherung und die islamischen Parallelstrukturen in Ägypten, Baden-Baden.

Seesemann, Rüdiger (1995). "Bacd malāmih al-ta'līm al-dīnī wa 'l-khalāwī fì Dārfūr" ("Some aspects of religious education in Qur ä̉nic schools in Darfur"), Dirāsāt Ifrìqūya (Khartoum), 13, 93-116.

- (1996). "Islam, Arbeit und Arbeitsethik: Die zāwiya der Tijaniyya in el-Fasher (Sudan)", in Arbeit in Afrika, Kurt Beck Gerd Spittler (eds), Hamburg, 141-60.

- (1999). "Where East meets West: Islamic educational institutions in Darfur/Sudan", Islam et sociétés au Sud du Sahara, 13, 41-61.

- (2000). "The history of the Tijaniyya and the issue of tarbiya in Darfur", in La Tijâniyya. Une confrérie musulmane à la conquête de l'Afrique, David Robinson/Jean-Louis Triaud (eds), Paris, 393-437.

- (forthcoming). "The writings of the Sudanese Tijānī shaykh Ibrāhīm Sīdī (1949-1999)", Sudanic Africa, 11, 2000.

Sīdī, Ibrāhīm (1989). Tajrubatī mac a 'l-ahdāth al-tașaddì wa 'l-tahaddì ("My experience with the youth: Meeting the challenge"), El Fasher.

al-Ṭayyib, al-Ṭayyib Muhammad (1991). al-Masid, Khartoum.

Trimingham, John Spencer (1949). Islam in the Sudan, London.

Voll, John Obert (1969). A history of the Khatmiyya tariqah in the Sudan. Ph.D. thesis, Harvard University.

- (1992). "Conservative and traditional brotherhoods", Annals of the American Academy of Political and Social Science, 524, 66-78. 


\title{
CHAPTER VI \\ Je veux étudier sans mendier \\ The Campaign Against the Qur’ānic Schools in Senegal
}

\author{
Roman Loimeier
}

\section{Introduction}

In 1992, the Senegalese government, UNICEF and a number of Islamic reform movements opened a national campaign against the Qurānic schools in general and the so-called talibé mendiants in particular. In a special edition of both the national daily newspaper Le Soleil, and the most important newspaper of the Islamic reform movement, Wal Fadjri, reports of a number of drastic cases depicting the misery of the talibé, the disciples of the Qur'annic schools, as they are called in Senegal, were presented to the public. One of the cases mentioned was that of the daara, the Qur'ānic school, directed by Sérigne Sulayman Seck in Kaolack. Bearing the title "Le mal-vivre au quotidien", this Qur’ānic school, established in 1978 and numbering 157 talibé in 1992, was described with the following words:

Le spectacle qui s'offre à la vue de ces petits talibés d'ont les ages oscillent entre 4 et 15 ans, est simplement révoltant. Tout dans ce daara inspire désolation et tristesse. ${ }^{1}$

The public image of the Qur’ānic school has never been positive. French colonial literature is particularly full of disparaging statements towards them. Thus, Paul Marty, director of the Bureau des Affaires Musulmanes since 1912, concluded his report in 1917 on the Qur'ānic schools in Senegal with the following statement:

L'école coranique, telle qu'elle fonctionne actuellement, est viciée de défauts de tous genres; personne ne les nie: enseignement purement confessionnel et purement mécanique qui n'exercice aucune influence sur le développement intellectuel de l'enfant; disparition lente des civilisations locales, et surtout immuabilité traditionnelle qui fait que nos Sénégalais s'islamisent en grande partie par la planchette des premiers siècles de l'hégire, et en restant là, à l'heure où l'Orient lui-même, berceau de l'Islam, se modernise ... ${ }^{2}$

\footnotetext{
${ }^{1}$ Le Soleil/Wal Fadjri, 8.4.1992, 14.

2 Marty 1917, 109.
} 
Un enseignement d'une valeur pédagogique aussi minime ne saurait avoir une grande valeur intellectuelle, surtout si l'on songe que les textes appris par les enfants ne leur sont pas expliqués, et qu'ils ne comprennent pas le sens des phrases qu'ils récitent ... 3

However, not only French writers, colonial officials and Marxist historians, such as Samir Amin and Jean Suret-Canale, ${ }^{4}$ depicted the marabuts and their schools in a bad light. African intellectuals, such as Lamin Sanneh also characterised the Qurānic school as a place of punishment and meaningless learning. ${ }^{5}$ Cheikh Hamidu Kane's novel L'aventure ambigué, that starts with a detailed description of the maltreatment of talibé Samba Diallo, is particularly known for its critical view of the Qur'ānic school and the marabuts' brutal methods of teaching. Yet, although Qur'ānic school education has been repeatedly characterised as having minimal pedagogical value, judgements such as these have to be regarded as severely biased. The outlook of both colonial officers as well as colonial scientists was usually connected with certain interests: generally, they were not interested in presenting the social role of the Qur ānic school and its teaching methods objectively. Rather, the socalled "conquête morale", the "moral conquest" of the African colonies was foremost in their minds. Quite simply, in the eyes of the colonial functionaries, the Qurānic school did not convey the skills that were appreciated by the colonial administration. ${ }^{6}$

The reform of existing educational concepts was, however, only ostensibly the aim of the campaign of the Senegalese state, UNICEF and Islamic reformers as mentioned above. Their campaign was designed rather to gradually dissolve the autonomy of the religious scholars in a central aspect of their social influence, namely that of educating and socialising the Muslims. With the new concept of education as propagated by the reformers, the established religious scholars are increasingly going to lose their role as mediators of knowledge. The campaign against the Qur ânic schools may thus be regarded as a step in a process of far-reaching social transformation within Islamic societies.

\section{The French "conquête morale" of an Islamic Society}

After the military conquest and political subjugation of its colonial territories France stated its additional intention to implement a cultural conquête morale of the colonies, an ideological programme that was also presented as a "mission civilisatrice". The Qurānic schools that were unconditionally accepted by many French colonial officers as a central institution of Islamic society were thus, in the context of the "conquête morale", increasingly seen as an

\footnotetext{
3 Marty 1917, 78

4 See Magassouba 1985, 65.

5 Sanneh 1997, 123ff.

${ }^{6}$ Wilks 1975, 166, and Harrison 1988, 59.
} 
annoying obstacle to development. ${ }^{7}$ Teaching in the Qurānic schools was discredited, sometimes even after the independence of the African colonies, as "dull and dumb memorisation without any sense and reason" or as a form of education "that defies all pedagogical technique". 8

In the context of its "conquête morale", France initially tried to obtain complete control over the system of Islamic education. As early as the nineteenth century, France thus began issuing bureaucratic regulations in order to restrict the existing Qurannic schools. The first decree designed to control the Qur'ānic schools was published in the form of Arrêté No. 96 sur les écoles musulmanes on June 22nd, 1857, and ruled that all Qurānic schools were obliged to obtain an official licence. ${ }^{9}$ In the following decades, between 1870 and 1896, this decree was continuously expanded and modified.

The most comprehensive effort to regulate the Qur’anic schools materialised in the form of another decree issued on July 15th, 1903, defining the conditions for running a Qur’ānic school. Accordingly no marabut was permitted to direct a Qurānic school without a licence issued by the governor of the colony. In order to obtain such a licence, the marabut was obliged to produce certification of his status as a teacher or a $q \bar{q} d \bar{l} \bar{i}$, as well as a certificate of good conduct and documentation testifying to his status as a French colonial subject. In addition, the marabut was obliged to undergo an examination as a Qurānic school teacher either in the presence of the $q \bar{a} d \bar{\imath}$ of the Tribunal Musulman of St. Louis or the local official in charge of the administrative area concerned. The directors of the Qurānic schools were asked to establish a register of their students in French and they were required to prove that their students also attended an official French school. Qur ānic schools comprising less than twenty students were to be closed down. Moreover, marabuts were prohibited from asking their disciples to collect alms. In 1903 a commission was established whose task it was to inspect the Qurānic schools. ${ }^{10}$ The decree of 1903 was supplemented by a further decree of June 12th, 1906. This decree ruled that every marabut who also taught French for two hours a day was to be awarded with an annual subvention of 300 Francs. ${ }^{11}$ Finally, in 1911, yet another decree was added to the apparatus of decrees stating that all ablebodied marabuts who nevertheless lived off the donations of their talibe were to be imprisoned for "vagabondage". 12

However, these decrees, designed to regulate the Qur'annic schools, were doomed to failure as the population as a whole was not willing to abandon the marabuts. French colonial bureaucracy quite simply lacked the power and

\footnotetext{
7 See Harrison 1988.

8 See Eickelman 1978, 490.

${ }^{9}$ Ndiaye 1985, 114.

10 Behrman 1970, 39-49.

11 Ibid., 39.

12 Ibid., 40.
} 
means to implement these decrees. ${ }^{13}$ With regard to the 1903 and 1906 decrees, the director of the Bureau des Affaires Musulmanes, Paul Marty, came to the following conclusions:

La réglementation ci-dessus exposée bouleverse toutes les coutumes, traditions et désirs des indigènes, elle semble les gêner à plaisir sans aucun profit pour notre action administrative ou politique. Aussi est-elle restée complètement inopérante. 14

In 1913 Marty thus proposed stopping the struggle against the Qurānic schools: he maintained that it would be futile to try and destroy an institution that fulfilled the needs of the population and which posed no political threat to the colonial administration. ${ }^{15}$ Incidentally, at that time, the colonial administration had already started to find ways of co-operating with the marabuts active in the production of groundnuts so as to improve the economic development of the colony. The colonial administration therefore accepted Marty's proposal and terminated its efforts to eliminate the Qur ānic schools. Instead, these schools were to be gradually integrated into the colonial system of education. ${ }^{16}$ Consequently, the decrees of 1903 and 1906, imposed in order to regulate the Qurānic schools were in fact never implemented. As a result, the existing structures of the Qur ānic schools, one of the most important foundations of marabut influence and authority, were to remain intact throughout the colonial period and, indeed, well into Senegal's period of independence. On account of the necessity to treat marabuts as allies, the bureaucratic measures originally introduced to eradicate the custom of giving alms and the habit of begging, particularly by the talibé, were never enforced.

\section{The Social Role of the Qur’ānic Schools}

The campaign against the Qurānic schools that was begun in the colonial period and continued in the postcolonial period ignored the fact that the acquirement of religious knowledge is culturally conditioned. ${ }^{17}$ Qur ānic school attendance in West Africa was thus not seen by the Muslim population as a way to acquire knowledge but rather understood as a religious obligation. ${ }^{18}$ It was neither the task nor aim of the Qurānic school to impart an understanding of the Qur'ān, God's word, to school children. Rather, the Qur'annic school taught the techniques of correct recitation of the holy text. ${ }^{19} \mathrm{In}$ the Islamic societies of West Africa, children were actually seen as Muslims in

\footnotetext{
13 Ibid., 40.

14 Marty 1917, 98.

15 Bouche 1974, 229.

16 Ibid.

17 Eickelman 1978, 481.

18 Fortier 1997, 94.

19 Goody 1975, 222.
} 
the making not yet in possession of the faculties of understanding $(\mathrm{fahm})$ and of reason ( $\left.{ }^{c} a q l\right)$. Children were supposed to first memorise the holy text and to slowly and gradually mature into Muslim adults. In this system of socialisation the parents permitted Qurānic school teachers to punish their children should they falsely recite the holy word of God: "A firm discipline in the course of learning the Qur'ān was culturally regarded as an integral part of socialisation" ${ }^{20}$

In many Islamic societies religious knowledge is still the most highly appraised and "powerful" form of knowledge, and the Qur"ān is seen as the paradigm of this knowledge. ${ }^{21}$ Intimate knowledge and the internalisation of the Qurān is thus the necessary sine qua non in religious studies. ${ }^{22}$ In this sense masters of Qur'ānic schools consider questions raised with regard to the meaning and content of the holy text as absolutely inappropriate for children to ask. Such questions are reserved for higher studies in religious sciences. They are not to be asked by children but by adult Muslims whose faculty of understanding $(\mathrm{fahm})$ and reason $\left({ }^{c} \mathrm{aql}\right)$ is acknowledged.

In the social setting of Islamic societies, the Qur ānic school is therefore less a place in which knowledge can be acquired but a school for life, namely, the socialisation of future Muslims. ${ }^{23}$ The Qur'ānic school should thus not be seen as disconnected from its social setting: education and socialisation were closely related. Hence, the Quraanic school teachers had a central role in society: not only were they advisers and "professional experts" 24 and mediators of the Qurān. Both due to their own socialisation as teachers and their connection with other scholars, as documented in their $i j \bar{a} z a$, they were also the last link in a long chain of scholars that ultimately connected them with the Prophet. Furthermore, the masters of the Qur ānic schools were often the legal experts and Imams of their respective communities. In their sermons they admonished the people and pointed out what their social and religious obligations were. ${ }^{25}$ Finally, in their schools another fundamental art was taught, an art highly esteemed in essentially oral societies, namely, that of holding speeches and of sacralizing them by quoting passages from the holy Qur ān from memory.

In this way the masters of the Qurannic schools slowly initiated the children into the adult world. The importance of the knowledge acquired in the Qurānic school was made clear to the children in the form of social competence and knowledge: they gradually became aware of the possibilities of

\footnotetext{
${ }^{20}$ Eickelman 1978, 494.

21 Eickelman, 1978, 490. For the presentation of the Islamic system of education in Africa see Goody 1975, Wilks 1975, Eickelman 1978, Sanneh 1979, Cisse 1992, Fortier 1997, and, most recently, Reichmuth 1998; for Senegal see Samb 1972, Ndiaye 1994, Loimeier 2001 and Wiegelmann 1998.

22 Eickelman 1978, 489.

${ }^{23}$ Ibid., 494.

24 Launay 1992, 149.

25 Ibid., 68-69.
} 
application of their memorised knowledge when accompanying their parents to public debates. At such events, they witnessed how skills acquired in the Qurānic school could be implemented in a socially meaningful way, for instance, by giving weight to arguments with memorised quotations from the Qur’ān:

On such occasions they heard adults incorporate Quranic verses into particular contexts and gradually acquired the ability to do so themselves, as well as to recite specific sections of the Qur'ann without regard for the order in which they had memorised it. Thus the measure of understanding was the ability to make appropriate practical reference to the memorised text, just as originality was shown in working Quranic references into novel but appropriate contexts. 26

Should this form of social competence, however, become obsolete, as due to processes of modernisation it in fact has, the Qur'ānic school is bound to lose its social relevance: it is going to be regarded as an institution foreign to an Islamic society in transformation which increasingly emphasises values of a non-religious nature.

\section{New Schools, New Teachers}

In the colonial period, the Quarannic schools only had to struggle against French colonial administration. Since the 1950s, however, Quar ānic schools have been confronted with a new, dangerous enemy: the Islamic reform movement and the Franco-Arab schools developed by the reformers. In his own youth, the founder of the Senegalese Islamic reform movement (the Ittih̄àd ath-Thaqāfi al-Islāmī, the Islamic Cultural Union or Union Culturelle Musulmane), Cheikh Touré had experienced Quar’ānic school education. He criticised this system of learning with the following words: "The marabut was regarded as a kind of God to whom nobody dared ask questions. The talibé behaved like a sheep vis-à-vis the marabut." 27 At the age of ten he had already rejected the system of marabutage: "I have never liked these talibé who demeaned themselves in front of the marabut." 28

In the 1950s, the struggle of the Islamic reform movement against the marabuts and their Quar'annic schools became a central topic of religio-political discourse in Senegal. The Islamic reform movement particularly accused the marabuts of collaborating with the French colonial power and held the established religious scholars responsible for Muslim inability to deal with the challenges of modernity. The Quar'ānic schools were regarded by the essentially urban based reformers as a symbol of an obsolete social system. In the 1950s, the Islamic reform movement established the first modern Islamic schools. These new schools came to be called "Écoles Franco-Arabes" as they

26 Eickelman 1978, 495.

27 Le Musulman, 26, 1989.

28 Le Musulman, 26, 1989. 
started to include subjects such as French in their syllabus. They adopted modern pedagogical principles, abolished talibé begging and the "mechanical memorisation" of the Qur ān. In place of these, they introduced new subjects such as history, mathematics, French, sports, history, geography and grammar, and also started to teach subjects such as hadith, figh and kalām, that had hitherto been restricted to ${ }^{c} \mathrm{ilm}$-studies. Also, the methods of learning in the new schools were radically different from those of the Quaraanic schools: techniques of memorisation were no longer trained and, consequently, texts were no longer recited in old fashioned Arabic from memory, but rather read from textbooks written in modern standard Arabic. ${ }^{29}$

From the outset of Senegalese independence, the government, under President Senghor recognised the importance of Islamic education and the possibilities of a reformed Islamic school system. In 1960, in state run schools Arabic was thus introduced as an optional subject ${ }^{30}$ and in 1963 Arabic was admitted as a "classical language" in the secondary schools alongside Latin and Greek. ${ }^{31}$ When a plan for national development was in the process of being drawn up in 1960, research was to reveal that in each village, up to 4-5 per cent, in the Fleuve region (St. Louis) even 25 per cent of the rural population were literate in Arabic. ${ }^{32}$

When considering the development of the Senegalese educational system in the postcolonial period, one must not overlook the fact that the percentage of school attendance has increased from 16 to 48 per cent between 1960 and 1992. At the same time, the number of pupils at the intermediate level of education, the so-called enseignement moyen, has risen to a percentage of 15.8, whereas the number of students in the enseignement secondaire, higher education, has increased to a percentage of 8.8 of all students. ${ }^{33}$ Nevertheless, the arabophone sector of education, at least at the pre-school and primary school level, still attracts more children than the state school sector. This observation is valid not only in the rural areas but also in the major cities of the country, such as St. Louis. Here, in 1991, 24,304 children were registered as pupils of 222 Quar'ānic schools, whereas the number of pupils attending one of the 37 state schools only amounted to 21,462 children. ${ }^{34}$

The persistent demand for arabophone religious education in the Quar'ānic schools was explained with a multitude of reasons: the Arab language would thus constitute part of Senegal's "patrimoine islamique"; Arabic had originally even been recognised by the colonial administration as its language of communication and administration. Thus, the first French paper in St. Louis, Le Manuel de St. Louis, had been published in Arabic. However,

\footnotetext{
29 Launay 1992, 94-95.

30 Ndiaye 1985, 214.

31 Coulon 1983, 99.

32 Sylla 1986, 154.

33 Wiegelmann $1994,803$.

34 Wiegelmann 1994, 808.
} 
when France came to realise that the French language had great difficulties in prevailing over the widespread use of Arabic, the colonial administration started to restrict the use of Arabic. As a result of these restrictions, solidarity with the Arabic language grew and Arabic came to be increasingly understood as the symbol of Muslim identity in the colonial situation, particularly in the context of the ongoing French efforts to achieve a "conquête morale" of their colonies. There has been growing demand among the population for independent access to the sources of their faith, which was not controlled or channelled by marabuts; the Arabic language would also prove to be of immediate interest in the economic relations with the Arab countries and students returning from their studies in such Arab countries began to introduce improved methods of teaching Arabic. ${ }^{35}$

In the 1970s, the second generation of the Islamic reformers, as represented by a number of new organisations such as the Jamā $\bar{a}^{c} a{ }^{c} I b \bar{a} d$ ar-Rahmān (The Association of the Servants of God), finally realised that the radical criticism which had been directed against the marabuts since the 1950s by Cheikh Touré's Ittih̄ād ath-Thaqāfi al-Islāmì was not supported by the majority of the population. The young reformers began concentrating their efforts on the expansion of the modern Islamic schools thereby improving their support among the population: knowledge was the only capital of the reformers. ${ }^{36}$

Efforts by the Islamic reform movement to expand the reformed Islamic school system were considerably increased in the 1980s. Throughout Senegal, in urban centres as well as in rural areas, new Franco-Arab schools were established by the reformers. Thus, a second sector of modern education was evolving. The Islamic reform movement saw these modern Islamic schools, however, not only as an alternative way of education as far as the Quar'ānic schools of the marabuts were concerned, but also as an alternative to the state controlled secular and francophone schools. By establishing their new schools, the Islamic reformers managed to provide jobs for students who had gone to Arab countries to study and who, upon return to Senegal, had not been integrated into the civil service. The new Franco-Arab schools also provided a means to improve the social status for a considerable number of children and students who had been hitherto rejected by the state schools and who had actually been forced to stop their education. By switching over to a FrancoArab school these children and students had the opportunity to complete their education. During the 1980s, the Islamic reform movement was thus set to considerably increase its social basis and influence especially in the urban areas. $^{37}$

\footnotetext{
35 Interviews with ${ }^{\mathrm{c}} \mathrm{Abd}$ al-Wahhāb Boly Ndao, Lecturer at the Departement des Langues et Civilisations Germaniques of the University of Dakar (2.4.1992), Iba Der Thiam, Minister of National Education 1983-1988 (21.3.1992), Mamadou Ndiaye, Director of the Departement de l'Arabe of the University of Dakar (13.4.1993) and Cheikh Touré, Founder of the Ittihād ath-Thaqāfi alIslāmī, ITI (13.4.1992).

36 Coulon 1981, 262.

37 See Loimeier 2001.
} 
In the sphere of modern Islamic education, the dynamics of the Islamic reform movement has forced the marabuts to generate ideas of their own in order not to lose their clientele to the reformers. As a consequence, since the early 1980s, the number of Franco-Arab schools established by marabuts has increased enormously and, by the late 1980s, even towns such as Touba, the capital of the Muridiya Sufi brotherhood, already had a number of modern Islamic schools. 38

Among the best known of these new Franco-Arab schools run by marabuts was the Institut al-Azhar in Ndame, founded in 1974 by Shaykh Muhammad Murtada Mbacké. By 1989, this school had established affiliate institutions in Bembey, Kaolack, St. Louis, Thiès and Bignona and its student population had increased to $39,627.39$ Other schools established by marabuts were the Institut d'Études Islamiques de Diourbel, established as early as 1956 by Cheikh Ahmad Mbacké, with affiliate institutions in Dakar, Louga, Kaolack and Mekhe which, together, numbered a total of 4,090 students; the Lycée Tafsir Ahmad Bâ, founded in 1968 by the Fédération des Associations Islamiques du Sénégal (FAIS), counting 395 students in 1989; the Institut Islamique Cheikh Abdallah Niass in Kaolack, founded by Ibrahim Niass in $1968 .{ }^{40}$ Since the late 1970s, this school has been transformed by Ibrahim Niass' successor, Cheikh Hassan Cissé, to become a model school counting 512 students in 1992. The student population included a considerable number of Nigerians, Ghanaians, Gambians and even 60 Afro-American Muslims. ${ }^{41}$

A typical example of marabut involvement in the sphere of education was the Institut Islamique Supérieur al-Hanafiyatou in Louga founded in the 1980s by Shaykh ${ }^{\mathrm{C}} \mathrm{Abbas}$ Sall, a marabut connected to the Tijāniya Sufi brotherhood. This school counted about 700 students in 1989. It had 18 classes, a boarding school, its own mosque, accommodation facilities for guests, an infirmary and apartments for its teachers. ${ }^{42}$ Teaching at primary level started in 1986 and was planned to continue up to secondary level. The curriculum of the school concentrated on languages, agricultural training and theology. ${ }^{43}$

The Franco-Arab school system in Senegal was able to assert itself as an alternative to the francophone state schools since many parents, particularly in the rural areas, refused to send their children to the state schools as those were seen as either secular or Christian. Parents were often unable to afford the comparatively high school fees, the school uniforms, teaching materials, transport and food. Finally, many parents perceived francophone education as being at odds with their own social reality. Consequently, they preferred to keep their children at home where were able to carry out useful household

\footnotetext{
38 Wal Fadjri 169, 23.6.1989.

39 Mbacke 1989, 88.

40 Coulon 1979, 28.

41 Wal Fadjri, 308, 16.4.1992.

42 Mbacke 1989, 89.

43 Le Soleil, 19.10.1987.
} 
and agricultural chores. Where parents sent their children to school at all they would send them to the Quar'ānic school of the local marabut. ${ }^{44}$

In some rural areas, this "réfus de l'école", 45 or rejection of the state schools, was quite remarkable. Especially in the Muridiya-dominated region of Diourbel a number of cases had been documented in which the state had opened new schools subsequently boycotted by the population. When these schools were to be closed by the state, the respective local communities approached the administration and asked them to reopen them as Arab schools. ${ }^{46}$

A recent study by Wiegelmann has also shown that education in at least some of the modern Franco-Arab schools is quite capable of competing with the state primary schools: tests simultaneously carried out in Franco-Arab schools, state schools and private schools showed that Franco-Arab school children were quite capable of competing with students in both state and private schools. ${ }^{47}$ Also, the rate of Arabic literacy in the rural areas in the agegroup of men over 40 continued to be higher than French literacy in the 1990s. ${ }^{48}$ Moreover, research carried out by Wiegelmann and Naumann in the Diourbel region concluded that the assumption, that the majority of Quar'annic school children did not learn anything, not even how to read and write, could not be maintained: Wiegelmann and Naumann show that, after two to four years of learning, most disciples of the Quarānic schools possess a good command over basic reading abilities. The survey showed that more than 60 per cent of the children attending a Quar ānic school in the research area also acquired writing skills. ${ }^{49}$

Quar’ānic schools and their marabuts have so far managed to survive in urban areas such as Dakar: firstly, Quar’ānic schools often serve as institutions which provide a sort of rudimentary home to children from rural areas sent to the cities by their parents in the hope that, under the tutelage of a trusted marabut, they will find a job in the city. Secondly, quite a few urban middle and upper class families continue to value the Quar ānic school education as a supplement to the predominantly secular oriented education offered by state schools. These families usually see the Quar'ānic school less as a way of acquiring "knowledge" than as a "school for life". ${ }^{0}$ Many well-off urban families even privately employ a marabut to teach their children the Qur"ān.

\footnotetext{
44 See Wiegelmann 1994 and Wiegelmann 1998.

45 Khayar 1976, 13.

46 Interview with Mohamed Fadel Dia, General Secretary of the Conférence des ministres de l'éducation des pays ayant en commun l'usage du français (1.4.1991), for an extensive discussion of the development of the Senegalese state school system and the religious private schools see Wiegelmann 1998.

47 Wiegelmann 1998, 325 and 338ff.

48 Wiegelmann 1998, 125-26.

49 Wiegelmann and Naumann 1997, 279.

50 Interview with Khadiye Fall, Lecturer at the Departement des Langues et Civilisations Germaniques, University of Dakar (3.2.1991).
} 
Yet, despite the support Quarānic schools enjoyed among the Senegalese population and despite the repeated vows of the Senegalese government to support the development of the Islamic educational system, the Quar ānic school system was to stagnate after independence. This stagnation was not only due to the lack of a uniform curriculum or chronic lack of money. A major feature providing an explanation for the stagnation of the Quar ānic schools was the refusal, on the behalf of the marabuts, to take part in a any state sponsored development programmes: they were afraid that such a state sponsored programme to reform Quar ānic schools would necessarily lead to greater government control. As control of Quar'ānic schools had already been a central feature in the French colonial period, any form of state intervention in the sphere of Islamic education was flatly rejected by the marabuts.

In the 1960s and 1970s, the marabuts in their capacity as groundnut producers and political intermediaries between the population and the ruling party, were still powerful enough to prevent any bureaucratic intervention in their sphere of social influence. Thus, as the state needed the marabuts as a central pillar of political stability, it refrained from any attempt to reform the Quarānic schools until the 1980s. Only in 1987, at a national conference organised by the Minister for National Education, Iba Der Thiam, was the reorganisation of the Islamic education system discussed. In the same year, a pilot curriculum for Quarānic schools was published that, in addition to teaching the Qur'ān (24 hours per week), also scheduled classes in reading / writing ( $21 / 2$ hours per week), mathematics ( 2 hours), handicrafts (1 hour) and civil education ( $1 / 2$ hour). This curriculum was adopted by two Quarāanic schools in Malika (near Dakar) and Latmengue (near Kaolack). These were seen as models for the improvement of the Quarānic school system. .1

The workgroup set up in 1987 to develop a uniform curriculum for the Franco-Arab schools was able to present the results of its work in 1990. Under the chairmanship of Dr. Thierno Kā, professor of Islamic studies at the IFAN (Institut Fondamental d'Afrique Noire) and Mufattish ${ }^{c} \mathrm{Amm}$ (General Inspector) of the Ministry of National Education, a total of 45 scholars, most of them Arabic teachers, developed a six year curriculum for the tanzìm at-taclim alcarabi al-hurr, the system of "free Arabic education", structured in the following way: 52

51 Prinz 1991, 26, and Prinz 1996, 99.

52 See Kā 1990, 6, 13, 18, 38. 


\begin{tabular}{|c|c|c|c|c|c|c|}
\hline \multirow[t]{2}{*}{ Class } & \multicolumn{6}{|c|}{ Number of teaching units per week per class } \\
\hline & 1. class & 2. class & 3. class & 4. class & 5. class & 6. class \\
\hline 1. $Q u r^{\top} \bar{a} n$ & 5 & 5 & 5 & 5 & 5 & 5 \\
\hline 2. hadith & 4 & 3 & 2 & 2 & 2 & 2 \\
\hline 3. figh & 3 & 3 & 2 & 2 & 2 & 2 \\
\hline 4. tauhīd & 2 & 2 & 2 & 2 & 2 & 2 \\
\hline \multicolumn{7}{|c|}{$\begin{array}{l}\text { 5. ethics-hygiene-civil } \\
\text { education ( } a k h l \bar{a} q \text { wa-t-tarbiya }\end{array}$} \\
\hline aș-șihhịya wa-l-madanìya) & 3 & 2 & 2 & 2 & 2 & 2 \\
\hline \multicolumn{7}{|l|}{ 6. conversation } \\
\hline (muhādatha) & 8 & 9 & - & - & - & - \\
\hline 7. reading & 8 & 9 & 6 & 6 & 6 & 6 \\
\hline 8. writing & 4 & 4 & 2 & 2 & - & - \\
\hline 9. learning exercises & 3 & 2 & 2 & 2 & 2 & 2 \\
\hline 10. mathematics & 8 & 9 & 6 & 6 & 6 & 6 \\
\hline 11. arts & 2 & 2 & 1 & 1 & 2 & 2 \\
\hline 12. sports & 2 & 2 & 2 & 2 & 2 & 2 \\
\hline 13. as-sìra an-nabawiya & - & - & 2 & 2 & - & - \\
\hline 14. expression $\left(t a^{c} b i r\right)$ & - & - & 2 & 2 & - & - \\
\hline 15. grammar (nahww/șarf) & - & - & 4 & 4 & 4 & 4 \\
\hline 16. history/geography & - & - & 2 & 2 & 2 & 2 \\
\hline 17. French & - & - & 6 & 6 & 7 & 7 \\
\hline 18. dictation $\left(a l-i m \bar{a}^{\jmath \prime}\right)$ & - & - & 2 & 2 & 2 & 2 \\
\hline 19. other & - & - & 2 & 2 & 2 & 2 \\
\hline 20. history of Islam & - & - & - & - & 2 & 2 \\
\hline 21. composition (al-insh $\left.\bar{a}^{\top}\right)$ & - & - & - & - & 2 & 2 \\
\hline 22. breaks & 9 & 9 & 9 & 9 & 9 & 9 \\
\hline Total & 61 & 61 & 61 & 61 & 61 & 61 \\
\hline
\end{tabular}

Teaching the Qur’ān was divided into the following steps:

1. class: al-Fätiha (1.), an-nās (114.) to al-bayyina (98.).

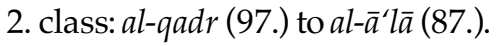

3. class: at-țāriq (86.) to an-naba (78.).

4. class: al-mursalät (77.) to al-jinn (72.).

5. class: $n \bar{u} h$ (71.) to at-tala $q$ (65.).

6. class: at-taghābun (64.) to al-mujādalah (58.).

Thus, by the end of the sixth class a tenth of the Qur'ān was supposed to have been learned. The new Franco-Arab curriculum presented far less demands on the students than the established Quar'ānic schools where the entire Qurān was memorised over the course of three to five years. Yet, while Quarannic schools exclusively concentrated on the memorisation of the Qurān, the new curriculum of the Franco-Arab schools was designed for the teaching of 21 different subjects in this way ensuring greater general knowledge. ${ }^{53}$

${ }^{53}$ Kā 1990, 6ff. 
Combined with the experience of studying at universities in Arab countries, the new type of Franco-Arab schools was also to produce a new type of scholar: the marabut, who through his isnād and his $i j \bar{a} z a$ was connected to traditions of teaching going back to the Prophet himself and to the revelation of the holy word of God, was replaced by the "professor", the ustādh, who received his education at a Franco-Arab school in Senegal and at a university in Egypt, Algeria or Saudi Arabia. Yet, even in Saudi Arabia, these institutions of learning were organised along the lines of western and inherently secular systems of education. ${ }^{54}$ When returning to their own countries these professors of Arabic and Islamic studies not only revolutionised the methods and contents of teaching but also started to influence the form of public Islamic discourse.

Thus, in the context of a political speech in Thiès on February 13th, 1993, the leader of the Dājirat al-Mustarshidin wa-l-Mustarshidāt (The Union of Rightly Guided Men and Women), an urban reform movement connected with the Tijāniya sufi-brotherhood, Sérigne Mustafa Sy attacked the Senegalese government with hitherto unknown force and appealed to his followers to vote for the opposition candidate in the forthcoming presidential elections, Abdoulaye Wade. In his speech, Moustapha Sy mixed different levels of discourse in a masterly fashion: he addressed the general public in the national language of Wolof, by inserting Arabic quotations he sought to sanction his discourse on a religio-dogmatic level, and, by means of far-flung excursions into world history and world politics in French attempted to communicate his world view to his audience. He also appeared in an outfit somewhat unusual for the typical public appearance of a marabut: his attire was that of an urban youth, namely, tight trousers and leather jacket. He even justified this appearance with a quotation from the Qur'ān:

Pardonnez-moi! Si je suis vêtu comme je le suis aujourd'hui c'est parce que je suis en campagne éléctorale. Comme les hommes politiques nous ont emprunté nos grands boubous, nos châles, nos chapeaux, nos cannes, nos versets du Coran et nos hadiths, moi aussi je leur emprunte leur pantalon, leur veste, leur casquette: «Ces jours (heureux et malheureux), nous les faisons alterner parmi les hommes ». Qui peut en décider autrement? Je les taquine tout simplement. Béni soit le Créateur! ${ }^{55}$

\section{The Campaign Against the Quar'ānic Schools and the talibé mendiants}

The development of a Franco-Arab system of education was not only a major goal of the Islamic reformers but also of the Senegalese state. By gradually eliminating the Quar'ānic schools the state sought to obtain greater influence in a social sphere dominated by the marabuts. The Senegalese government

\footnotetext{
54 Launay 1992, 98.

55 Kane and Villalon 1995, 130.
} 
also hoped to reach groups of the population that had managed to escape direct state control with respect to education. ${ }^{56}$ The dominant position of the Quarānic schools in rural areas was regarded by both the Senegalese state and Islamic reformers as an impediment to the improvement of standards of teaching of the Quarāanic schools seen by both parties as deficient. In the 1980s and 1990s, many Quar'ānic schools were still characterised by rudimentary conditions of learning: the wooden slate was used and teaching was marked by rigid discipline. In addition, many Quar'ānic schools, particularly in urban areas, had two different types of talibé: day talibé who came from the immediate neighbourhood of the school and boarding pupils entrusted by their parents, usually living in distant rural areas, to marabuts in the cities. Most of the talibé mendiants were recruited from this second type of talibé. ${ }^{57}$

On account of the on-going economic crisis in Senegal, in the 1990s, marabuts were no longer in a position to provide proper housing, food and care for the talibé entrusted to them. As a social institution they were to become increasingly redundant. Also, financial support from parents could not be relied upon despite occasional donations and zakatt-payments for the subsidy and improvement of their comparatively impoverished conditions. The marabuts were forced to send their talibe into the streets to beg. Yet, despite begging, the marabuts were frequently unable to properly house, feed and clothe their talibé or even provide them with medical care. As a consequence the talibe often suffered from diseases of the skin and eyes as well as from malnutrition. ${ }^{58}$ Also, the talibé were often used by the marabuts for begging purposes so as to ensure that the marabuts' personal needs were met. Many urban marabuts continue to use their talibé as a source of income, legitimising begging as a means of education. ${ }^{59}$

In fact, at least in West African Islamic societies, talibé begging practices have been regarded as legitimate as long as begging was confined to the collection of alms in front of the mosques on Fridays. This form of begging was accepted as a way of fulfilling the religious duty of paying zakāt to the poor and needy. In modern Senegalese cities, however, begging has turned into a fulltime occupation among the talibé mendiants. Instead of learning, many talibé, usually small children, often presenting a rather neglected impression, drift around city streets, a habit tolerated or even expressly authorised by the marabut, begging for food and money while reciting haphazard selections of verses from the Qurān. Sometimes they form street gangs and commit acts of petty crime. In a recent estimation from 1995 the Senegalese government and UNICEF estimated that the number of these talibe mendiants ranged from 50100,000. The non-governmental organisation ENDA (Entente Nationale pour le

\footnotetext{
56 Coulon 1983, 105.

57 Wiegelmann and Naumann 1997, 280.

58 Ibid., 281.

59 Wiegelmann and Naumann 1997, 283.
} 
Developpement et l'Assistence) estimated that in 1992, their number was as high as 150,000 children. ${ }^{60}$

Both secular state and Islamic reformers were of the opinion that this system of marabutage could only be fought by offering alternative ways of education. The talibé mendiants, already under attack by the colonial administration were, thus, again to become centre of public interest in the 1990s: as a visible sign of the decay of the Quar'ānic school system, the talibe mendiants were used as a pretext for attacking the entire structure of established Islamic education. However, unlike the criticism of talibé mendiants, exploitation in colonial times, the initial source of criticism derived from Islamic reformers and not from the government. The Senegalese government, until the assumption of power by President Diouf in 1981, did not dare publicly criticise the powerful marabuts on whose support the stability of the regime largely depended. On the other hand, the first seminars on the Quar ānic school system were held at the Institut Islamique de Dakar, the centre of the reformist groups, as early as the mid-1970s. The proposals put forward by the Islamic reformers for improving the situation of the talibe were not registered by the government at that time. ${ }^{61}$

It was only in the early 1990s that criticism of the Quar'ānic schools increased, more especially during the campaign initiated by UNICEF and the Senegalese state mentioned above, designed as it was to improve the protection of children's rights. In the form of an international development programme this campaign was publicly implemented on March 31st, 1992. It was entitled "The international convention for the preservation of children's rights". In Senegal, the campaign drew special support from the technocratic elite which had significantly increased its political power under President Diouf, as well as from a number of Islamic reform groups. As a Muslim president, with strong connections to the Tijāniya Sufi brotherhood, Diouf was in a better position than his Catholic predecessor Senghor as far as a critique of established social structures such as the Quar’ānic school system was concerned. In cooperation with UNICEF, a national programme was published in 1992 designed to improve the living conditions of children "en situation particulièrement difficile". ${ }^{62}$ The programme was to span a five year period (1992-96) and was specifically directed towards the "réhabilitation des droits des talibés". The programme also provided for the marabuts in the form of technical as well as financial support with which they were to improve their schools or the economic status of the talibe, for instance in the form of school gardens. Teaching was to be modernised and literacy courses were to be given. The overall aim was to achieve integration of the existing Quar'ānic schools into new communitarian structures of education. A precondition for

\footnotetext{
${ }^{60}$ Ibid., 273.

61 Ibid., 284.

62 Wiegelmann and Naumann 1997, 286.
} 
joining the programme was that the marabuts declare their willingness to stop talibé begging and to dispense with corporal punishment. ${ }^{63}$

The campaign focussed on the rural milieus, at the very centre of marabut power. With regard to the Senegalese public, the campaign was accompanied by a national information programme broadcast on national radio, TV and featured in national newspapers. The purpose here was to sensitise the population to the precarious situation of the talibé attending Quar’annic schools. The initial results indicated that the campaign met with some resistance from the marabuts. At first, only a few well known Quar'ānic schools were awarded funds, such as Hassan Cissé's school in Kaolack or the school at Malika near Dakar, both mentioned above. ${ }^{64}$ In addition, many marabuts interpreted the campaign for talibé mendiant rehabilitation as an attempt to impose western, secular concepts of education and socialisation on the Quar'annic schools. As a consequence, by 1996, the programme for the rehabilitation of the Quar'ānic schools was only to have affected 20,000 talibé. ${ }^{65}$

The true direction of the rehabilitation campaign can be read in the special edition of the national newspaper Le Soleil and in the biggest newspaper of the Islamic reformers, Wal Fadjri, published on April 8th, 1992. Under the title Les enfants d'abord-la longue marche des talibés a number of articles entitled, for instance, Thiès - au carrefour de la mendicité, Santé: une note salée, Le mal-vivre au quotidien, presented talibé living conditions in the most sombre of details: children were abandoned by their parents and left to the unscrupulous care of marabuts in the big cities. There they were forced, under unspeakable living conditions, to beg for their masters who had found in their talibé a moyen confortable de gagner leur vie. ${ }^{66}$ Thus, the characterisation of the talibé living conditions in the Quar'ānic schools remarkably resembles the description of the Quarānic schools known in colonial times. In the article $\hat{E}$ tre talibé, for instance, Ousseynou Gueye of the Islamist paper Wal Fadjri, characterises the living conditions of the talibé as such:

Le talibé vit dans des conditions très précaires. A «l'age de l'innocence » il voit les meilleures années de sa vie sacrifiées. Il a généralement entre 5 et 15 ans. La misère et la souffrance demeurent son lot quotidien et il passe le plus clair de son temps à mendier pour le compte du marabout. ... Dans tous les domaines, le talibé est à plaindre. Il vit dans des locaux de fortune où il couche par terre. Dans le meilleur des cas, il dort sur une natte. Mais c'est rare. Dans beaucoup de daaras que nous avons visités à SaintLouis, Aére Lao et Yeumbeul, des cartons servent de matelas. Le talibé partage ses lieux d'habitation avec les puces, les cafards et toutes sortes de petites bestioles. ... Quand l'État subventionne le daara, n'allez pas croire que cela va se repercuter sur la vie du talibé. Au contraire, la somme d'argent, les vivres et vêtements alloués aux daaras servent le plus souvent pour la nourriture de sa famille. ... Dans le daara quand le talibé

63 Ibid., 287.

64 Ibid., 288.

65 Wiegelmann 1998, 105.

66 Le Soleil/Wal Fadjri, 8.4.1992, 11. 
croupit dans la misère, le marabout et sa famille peuvent vivre à coté une situation des plus aisées. ...67

The presentation of the misery in the Quar'anic schools, the desperate living conditions of the talibe and the cynical attitudes of the marabuts are illustrated by a number of crude cases of pauperisation in Quar'ānic schools such as the daara of Sérigne Suleyman Seck as already mentioned. This establishment, located in Kaolack, was led by a handicapped marabut who was no longer able to provide any sort of social assistance and care for his talibé. This documentation of misery contrasts with a few positive cases such as the school of Hassan Cissé in Kaolack. However, such an example merely highlights the misery of the other Quar'ānic schools. The rationale behind this propagandistic presentation was clear: the secular state attempted to create a setting that would legitimise intervention in the sphere of the marabuts' social influence. Under the pretext that marabuts were incapable of properly running their own schools, this policy would consequently lead to the marginalisation of the marabuts. In an interview on April, 8th, 1992, the Minister for National Education, Asane Diop, declared:

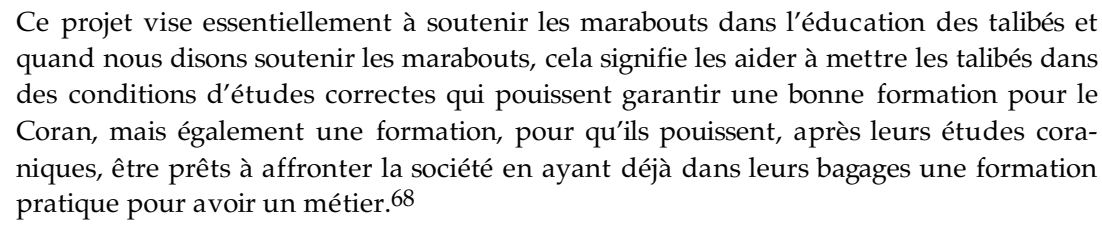

Ce projet vise essentiellement à soutenir les marabouts dans l'éducation des talibés et quand nous disons soutenir les marabouts, cela signifie les aider à mettre les talibés dans des conditions d'études correctes qui pouissent garantir une bonne formation pour le Coran, mais également une formation, pour qu'ils pouissent, après leurs études coraniques, être prêts à affronter la société en ayant déjà dans leurs bagages une formation pratique pour avoir un métier. 68

Again, as was the case during the colonial period, the type of socialisation cultivated by the Quar'ānic schools was declared irrelevant to the needs of modern society which demanded training in practical skills enabling Muslim children to confront the challenges of modern life. However, in consideration of the dire living conditions of many talibé, in the urban areas in particular, the campaign of the Senegalese government against the most outstanding abuses of Quar'ānic school education, for the first time, had a chance to bring about some real change as far as the established structures of Islamic education were concerned.

\section{Conclusion}

Secular state and global development agencies such as UNICEF, as well as Islamic reformers were united in their attempt to dissolve the existing Islamic system of socialisation maintained by the Quar'ānic schools. They were all of the opinion that the autonomy of the Quar ānic school as a central institution of Islamic society had to be destroyed and the social and political influence of the

67 Le Soleil/Wal Fadjri, 8.4.1992, 13.

68 Interview with Assane Diop, Minister for Santé publique et action sociale, published in Le Soleil/Wal Fadjri, 8.4.1992, 12. 
marabuts, the established religious scholars, must be eliminated. So, the attack on the Quar'ānic school may be seen as an attack on the very foundations of Islamic society and, in this sense may be interpreted as a further step towards the "disenchantment of the world" 69 by the secular state and the Islamic reformers: in the reformed Islamic schools, education is no longer seen as a vehicle for conveying social and moral values but as a way of imparting practical skills "relevant" in a modern, increasingly individualistic and desacralised society. The only difference between state schools and Franco-Arab schools is that in the latter, teaching is conducted in Arabic instead of in French or in English and that children do get basic notions of established Islamic subjects such as kalām, hadìth and figh. Again, Arabic is no longer seen as a sacred language reserved for scholarly use. It is also regarded as a practical tool that might enhance employment prospects in Arab countries. ${ }^{70}$ Finally, the purpose of the Islamic reform movement's schools is not to initiate children into adult life. They are rather oriented towards materialistic objectives: the students of these schools are supposed to develop "marketable skills". ${ }^{71}$

The disenchantment of Islamic societies is thus shown by the crisis of the Quar'ānic school. This crisis is strengthened by the general economic malaise which has aggravated the situation in many Quar'ānic schools and made them vulnerable to criticism. The transformation of the role of religious knowledge and the role of the Quarannic schools which taught mnemonic domination of sacred knowledge through the mediation of a respected religious authority, into a new form of education that can be consulted in handbooks at any time and which can be interpreted individually without the mediation of a religious expert, is a sign of significant social change. The consequences of this process of change are that Quar'ānic schools and religious scholars have ceased to be the only institutions for mediating religious knowledge. Today, they have to compete with Islamist reformist schools as well as secular state schools. With their modern education, the teachers of these new schools also claim the right to interpret the holy texts:

\footnotetext{
The carriers of religious knowledge will increasingly be anyone who can claim a strong Islamic commitment; freed from mnemonic domination, religious knowledge can increasingly be delineated and interpreted in a more abstract and flexible fashion. A long apprenticeship under an established man of learning is no longer a prerequisite to legitimize one's own religious knowledge. 72
}

Therefore, the attack on the Quaraanic schools and the social structures connected with them, the development of new models of education and new teaching methods and the claims connected with these, namely, individualistic access to and interpretation of the holy texts, as well as the de-sacralisation of learning is not only a direct attack on the ${ }^{c}$ ulam $\vec{a}^{3}$ as preservers and

\footnotetext{
69 Weber $1920 / 88,94-95$.

70 Launay 1992, 93.

71 Ibid., 94.

72 Eickelman 1978, 512.
} 
mediators of sacred knowledge but also represents a paradigmatic change in Islamic societies-at least as far as their self-image as an Islamic society and their conception of socialisation is concerned. In this process of change the Quarānic school is perhaps not going to totally disappear but its role and character are certainly going to be transformed.

\section{References}

\section{Interviews}

Mohamed Fadel Dia, General of the Conférence des ministres de l'éducation des pays ayant en commun l'usage du français (1.4.1991).

Khadiye Fall, Lecturer at the Departement des Langues et Civilisations Germaniques, University of Dakar (3.2.1991).

Boly Ndao, Lecturer at the Departement des Langues et Civilisations Germaniques of the University of Dakar (2.4.1992).

Mamadou Ndiaye, Director of the Departement de l'Arabe of the University of Dakar (13.4.1993).

Iba Der Thiam, Minister of National Education 1983-1988 (21.3.1992).

Cheikh Touré, Founder of Ittihāe ath-Thaqāfi al-Islāmī, ITI (13.4.1992).

\section{Literature}

Behrman, Lucy C. (1970). Muslim Brotherhoods and Politics in Senegal, Harvard.

Bouche, Dennis (1974). "L'école française et les musulmans du Sénégal de 1850 à 1920", Revue française d'Histoire d'Outre-Mer, 233, 218-34.

Cisse, Seydou (1992). L'enseignement islamique en Afrique Noire, Paris.

Coulon, Christian (1979). "Les marabouts sénégalais et l'Etat", Revue francaise d'études politiques africaines, $158,15-42$.

-(1981). Le Marabout et le Prince, Paris.

-(1983) Les reformistes, les marabouts et l'état, CERMAA, Paris.

Eickelman, Dale F. (1978). "The art of memory: Islamic education and its social reproduction", Comparative Studies in Society and History, 20, 4, 485-516.

Fortier, Corinne (1997). “Mémorisation et audition: l'enseignement coranique chez les Maures de Mauritanie", Islam et Sociétés au Sud du Sahara, 11, 85-108.

Goody, Jack (1975). Literacy in Traditional Societies, Cambridge.

Harrison, Christopher (1988). France and Islam in West Africa, 1860-1960, Cambridge.

Kā, Thierno (1990). Al-Lajna al-Wațanìya li-I ${ }^{c} \bar{a} d a t$ Tanzīm at-Ta ${ }^{c} \overline{l i m}$ al- ${ }^{c}$ Arabì al-Hurr fi-Sinighālal-Marhala al-Ibtidācicya, Tunis.

Kane, Ousmane and Leonardo Villalon (1995). “Entre confrérisme, réformisme et islamisme: Les Mustarshidîn du Sénégal. Analyse et traduction commentée du discours éléctoral de Moustapha Sy et réponse de Abdou Aziz Sy junior", Islam et Sociétés au Sud du Sahara, 9, 119-202.

Khayar, Issa H. (1976). Le Refus de l'École, Paris.

Launay, Robert (1992). Beyond the Stream. Islam and Society in a West African Town, Berkeley.

Loimeier, Roman (2001). Säkularer Staat und Islamische Gesellschaft. Die Beziehungen zwischen Staat Sufi-Bruderschaften und islamischer Reformbewegung in Senegal im 20. Jahrhundert, Hamburg.

Magassouba, Moriba (1985). L'Islam au Sénégal, Paris.

Marty, Paul (1917). Études sur l'Islam au Sénégal. Tome II: Les Doctrines et les Institutions, Paris.

Mbacke, Karim (1989). Le soufisme et les confréries réligieuses au Senegal, Dakar. 
Mbacke, Khadim and Kā, Thierno (1994). "Nouveau catalogue des manuscrits de l'IFAN, Université Cheikh A, Diop", Islam et Sociétés au Sud du Sahara, 8, 165-99.

Ndiaye, Mamadou (1985). L'enseignement arabo-islamique au Sénégal, Istanbul.

- (1994). L'enseignement arabo-islamique au Sénégal, ISESCO (Organisation islamique pour l'éducation, les sciences et la culture), Culture et civilisations islamiques-Sénégal, Rabat.

Prinz, Manfred (1991). Kulturtragende Institutionen des Senegal, Bayreuth.

- (1996). L'Alphabétisation au Sénégal, Paris.

Reichmuth, Stefan (1998). Islamic Education and Scholarship in Subsaharan Africa. Unpublished manuscript, Bochum

Samb, Amar (1972). Essai sur la contribution du Sénégal à la litterature d'expression arabe, Dakar.

Sanneh, Lamin (1979). The Jakhanke. The History of an Islamic Clerical People of the Senegambia, London.

- (1997) The Crown and the Turban. Muslims and West African Pluralism, Boulder.

Sylla, 'Abd al-Qādir (1986). Al-Muslimūn fì s-Sinighāl. Macālìm al-Hādịir wa Afā al-Mustaqbal, alDūhā (Qatar).

Weber, Max (1920/1988). Gesammelte Aufsätze zur Religionssoziologie I, Tübingen.

Wiegelmann, Ulrike (1994). “Die Koranschule-Eine Alternative zur öffentlichen Grundschule in einem laizistischen Staat?", Zeitschrift für Pädagogik, 40, 5, 803-20.

- (1998). Alphabetisierung und Grundbildung in Senegal. Ein empirischer Vergleich zwischen modernen und traditionellen Bildungsgängen und Schulen. PhD thesis, Münster.

Wiegelmann Ulrike and Craig Naumann (1997). "Zwischen Ausbildung und Ausbeutung: Die talibés mendiants im Senegal", in Strassenkinder und Kinderarbeit: Sozialisationstheoretische, historische und kulturvergleichende Studien, Christel Adick (ed.), Frankfurt, 273-91.

Wilks, Ivor (1975). "The Transmission of Islamic Learning in the Western Sudan", in Literacy in Traditional Societies, J.Goody (ed.), Cambridge, 161-97. 


\title{
CHAPTER VII \\ A Survey of Islamic Non-Governmental Organisations in Accra
}

\author{
Sulemana Mumuni
}

\begin{abstract}
Ghana has witnessed an upsurge in organisations, associations and clubs in recent times. Whilst the orientations of some of these bodies are socio-economic, some are politico-religious and others too are environmental. Within the Muslim community in Ghana in general and Accra in particular, religion has played the key role. Some of the Islamic organisations in Accra are of ethnic origin whilst others have a clear doctrinal background. However, they all have similar aspirations as deduced from their aims and objectives, being the furtherance and well-being of the Muslim population. A survey conducted at the Deeds Registry in Accra, responsible for the registration of the trustees of non-profit making organisations revealed that over sixty Islamic organisations are registered. In addition, there are quite a number of organisations that have not been registered with the Deeds Registry. Due to lack of information on most of these organisations, I will concentrate on the formation of migrant and indigenous organisations, women associations and on the eight Islamic councils that have operated in Ghana since independence.
\end{abstract}

\section{The Composition of the Muslim Community in Accra}

Although belief and observance of Islam bound Muslims into a brotherhood, Muslims in Accra do not form a homogeneous group. Accra, which has been the political and administrative capital of the country since 1877, has today a population of about 1.5 million among which Muslims constitute about eleven per cent. Accra is associated with three major religious traditions, which are the Ga Traditional Religion, Christianity and Islam. The origins of the Muslim community in Accra are clearly different at least geographically and ethnically. As Muslims, they do not function as an amorphous group but are organised along certain lines to satisfy the religious, social, economic and political needs. Two major modes of organisation stand out as the earliest modes of Muslim organisation in Accra, namely organisation along ethnic lines and organisation along doctrinal lines. The ethnic organisation of Muslims in the Accra metropolis can be classified into migrant Muslim settlers and indigenous Ga Muslims. The migrant Muslims can again be sub-divided into three classes: 'alien' African migrants, national migrants and non-African migrants. It is significant to note that the migrants constitute the majority in 
the Accra Muslim community. They have also monopolised the secular and spiritual leadership, particularly the alien African migrants

\section{Zongo}

The organisation of Accra Muslims along ethnic lines brought about ethnic leadership referred to as Muslim Chiefs (Headmen). Migrant Muslims are also noted for settling into distinct wards or sections of geographically located communities. Muslim sections or enclaves of Accra and elsewhere on the coast are referred to as zongo, a Hausa word which means a segregated quarter at the periphery of towns and cities. However, according to Dinan, in Ghana the word is used to refer to the residentially segregated quarters where strangers, especially Muslims, settle. ${ }^{1}$ The Muslims in Accra always moved to the suburbs of the growing Accra, founding new ones and leaving behind numerous settler and Hausa names. The reasons for the movements of the Muslim quarters were mainly due to the environmental hazards caused by their cattle. However, according to Opoku, who investigated the fast development of Madinah from merely farmland in the 1950s into today's 'mixed' suburb with residents of various ethnic groups, the lack of amenities and thus the cheapness of the rent was another reason which made establishment of Muslim settlements on the outskirts of the town "attractive". 2

Zongo in Accra can be appropriately described as a community within a community. Zongo is not a new phenomenon in Islam in West Africa. Clarke quoting Arab writers illustrates that already during the eleventh century Muslim merchants had built their own quarters within Koumbi-Saleh, the capital of ancient Ghana. Koumbi-Saleh was made up of two quarters, one of which was inhabited by the Muslims. The Muslim quarter was a big town with twelve mosques, one of which was for public prayers on Friday. Muslim lawyers and academics resided there. The other quarter, the royal town was situated six miles away where the indigenous people and their chief lived. ${ }^{3}$

Naino Iddris, the first Hausa migrant to settle in Accra, established the first zongo in Accra in Ussher Town referred to as Zongo Mallam in 1850. Zongo Mallam expanded to Okaishie and the current General Post Office Square. Today, the old part of Zongo Mallam is known as Cowlane. Naino became the first chief of Zongo Mallam and Imam of Accra. By 1908, the migrant Muslims outgrew Zongo Mallam, which led to the establishment of new settlements such as Tudu, Adabraka, Sabon Zongo, Fadama, Lagos Town, Nima, Kanda, Maamobi, Kotobabi, al-Hamdu, Shukurah, Alajo, Akweiteman and Madinah. ${ }^{4}$

\footnotetext{
1 Dinan 1975, 45.

2 Opoku 1967.

3 Clarke 1982, 37.

4 See further Mumuni 1994, 34-39.
} 
With regard to the zongos described above, it is important to note that Islam appears to be the major cohesive factor drawing various ethnic groups as well as geographically and culturally diverse ones together in the zongos. These settlements are distinguished from their predominantly Christian and Traditional neighbours in different ways. Mosques are found all over these zongos and at least the adhan (call to prayer) is heard five times daily. Their mode of dressing also makes them distinct in the metropolis. Islamic festivals and holidays bring the Muslims together from all over Accra. Therefore, the zongos maintain a strong sense of identity and exclusiveness. In connection with this unique status of the zongos, Trimingham notes:

Settlement in the new towns scarcely changes long established Muslims. On the contrary they are the most traditional and conservative of all their inhabitants. The new urban milieu hardly changes ... such colonies and the atmosphere in which their children grow up is little removed from that of a village. 5

\section{Alien and National Migrants}

The alien African migrants either came from Nigeria or the French-speaking West African states. The major ethnic groups such as Hausa, Yoruba, Fulani, Nupe, Kanuri came from Nigeria, whilst the Wangara (Yarse, Dyula, Mande), Mossi, Kotokoli, Chamba, Zambarama, Kado Gruma, Chokosi and Basari came from the Franco-phone West African states. These migrants arrived on the coast of Ghana either as traders or itinerant clerics.

The pre-eminent migrant ethnic groups were the Hausa and Yoruba. Naino Iddris (d. 1893) is remembered in oral traditions as the first Hausa Muslim to settle in Accra, probably in 1850. He came from Katsina in Hausaland to the Gold Coast in the company of his wife, his brother Mallam Abu Bakr (Garubah) and his son Mallam Muhammad Bako. Other prominent Hausa migrants besides the family of Naino were Mallam Muhammad Shawi who moved from Hausaland and finally settled in Accra and resided with Naino. Mallam Shawi's son Muhammad Abass became Imam of Accra in 1929 and was succeeded by his son Mukhtari Abass who was succeeded by the current National Chief Imam Shaykh Uthman Nuhu Sharubutu. Retired soldiers from the Gold Coast Hausa constabulary also augmented the Accra Hausa community. Officer Ali, who was an acclaimed head of the community, used his influence to acquire land from the colonial government and with contributions from the Muslim community in Accra the central Mosque at Makola was built. However, in 1986 the old central mosque in Accra was razed to the ground by bulldozers to make room for the "Rawlings Car Park". 6 Bawa Kadri English succeeded Officer Ali as the leader of the Hausa community. Today the community is headed by Ali Bawa Kadi English; Bawa's son.

5 Trimingham 1959, 215.

6 "Central Mosque Goes Down At Last", Daily Graphic, 20 /10/1986. 
The earlier Yoruba migrants came from Abeokuta. The first chief of the Yoruba community was Brimah the butcher, who came from Ilorin. By the 1880s he was already established in Accra as a successful butcher and was later to emerge as an ardent organiser of the Muslims in Accra. In 1909 he was appointed by Governor Nathan as the first non-indigenous Muslim chief in Accra. He died on 4 May 1915 and left behind five children.

The Fulani also played a leading role in the activities of the Accra Muslim community. Mallam Fulata Bornu, a Fulani from Marwa came on foot to Accra. He first settled with a relative of Mallam Nuhu and later moved to join the Baako family. In 1903 he became the Imam of Accra (1903-1905). Another prominent Fulani migrant was Mallam Nuhu who settled at Kotobabi a suburb of Accra. He became Imam of Accra in 1960-1966.

Thus, while the Yoruba gave the Accra Muslim community secular leadership, the Hausa and Fulani gave the community its spiritual leadership. Since 1850 to date, Accra has had 13 Imams out of which eight were Hausa and the remaining five were Fulani. The first Imam was Naino Iddris, a Hausa, and the current one another Hausa in the person of Uthman Nuhu Sharubutu. It is also worth noting, that the Imam of Accra is also the National Imam of Ghana since Accra is the capital of the state.

The national migrants mainly are those who came from the northern territories of the Gold Coast. These included the Gonja, Dagomba, Nanumba, Mamprusi, Wala and Grunshie. The national migrants came to the coast either as slaves or to seek employment in the public and private sectors. Sometimes they also rendered certain services such as being butchers and wanzams, natives who offer services such as shaving, clipping of nails and circumcision. After the Aliens Compliance Order of 1969, which resulted in the departure of more than a million alien African migrants, there was an influx of more northern migrants to the towns of the south, especially Accra. The national migrants then flooded the coast to trade particularly in foodstuffs that hitherto had been the domain of the alien African migrants.7

The non-African group comprised the Lebanese, Syrian and after independence in March 1957, the officials of the Arab and Islamic missions in Accra. The great boom in the export of cocoa in $1919 / 20$ brought prosperity to Accra. The city became attractive not only to European firms but also to Asian, Syrian and Lebanese merchants. The Muslims in the Lebanese and Syrian communities in Accra contributed greatly to the development of Islam in Accra. The Lebanese community in particular took great interest in the financing and maintenance of mosques in Accra through the Islamic Educational Trust and the Ghana Society for Islamic Education and Reformation, both established in the middle of the 1970s. Bilateral and friendly relations with Arab and Islamic states led to the opening of Arab and Islamic Missions in Ghana after independence. Today Egypt, Saudi Arabia, Algeria, Libya, Lebanon, Pakistan and the Islamic Republic of Iran as well as the State

${ }^{7}$ Mumuni 1994, 40. 
of Palestine have Missions in Accra. A majority of the diplomats and officials in these Missions are Muslims thus opening another chapter in the development of Islam in Ghana and Accra in particular. ${ }^{8}$ The divestiture of state enterprises in the middle of the 1990s witnessed the advent of Malaysians into the county. The Malaysian Muslims are contributing towards the social development of Ghana through the Ghana Islamic Development Association (GIDA).

\section{The Ga Muslim Community}

The second major group of Muslims in Accra are the indigenous Ga Muslims. Around 1900 Kwashi Solomon became the first Ga Muslim convert. His conversion took place five decades after the first Hausa migrant Muslim settled in Accra. In 1931 Yushau Ayikwei Aryee a Protestant was converted to Islam through his search for the proper way of worshipping God. It is said that, as a result of his search, he had a vision that instructed him to accept Islam as a religion. ${ }^{9}$

The Ga Muslim community increased in the 1940s and according to Anderson, this was because the Ga became dissatisfied with the Traditional beliefs whereas Christianity came to be viewed as a foreign imposition. ${ }^{10}$ However, Alhaji Suleman Kasim Quartey attributes the trend to the similarity between the Islamic rituals and rites and the Ga culture. He opines that Ga might have come into contact with Islam before their migration to their present settlement. ${ }^{11}$ The pioneer Ga Muslims were converted by the migrant Muslim clerics. However, it is worth noting that the subsequent process of Islamisation was championed by the Ga pioneer Muslim converts. Ga Muslims are found all over the Accra metropolis, especially in Bukom, Mamprobi, Korle Gonno, Teshie-Nungua and Mabrouk. ${ }^{12}$

\section{Organisation along Doctrinal Lines}

There exist a number of Islamic organisations in Accra, the origins of which are on doctrinal lines, among others the Tijānīya Sufi brotherhood, the Ghana Sufi Council, the Islamic Research and Reformation Centre, the Supreme

\footnotetext{
8 Mumuni 1994, 42.

9 Interview with Haji Suleman Kassim Quartey, Vice National Chairman, Ghana Muslim Mission. See further Dretke 1968. Aryee's contemporaries who followed his example were Alhaji Ibrahim Lamptey, Muhammed Markwei Laryea, Godwin Ahmed, Musa Doudu, Yakubu Blackson, Alihu Ankrah, Dauda Lamptey among others. These pioneer Ga Muslims were followed by Justice Yaccubu Ammah, Mahmood Lamptey, Alhaji Musah Quarty, Dauda Otoo and others. Most of them joined Islam with their families. The late Madam Mariama Dedey Akanuah was one of the pioneer Ga women to embrace Islam independently.

10 Anderson 1978, 282.

11 Interview with Haji Suleman Kassim Quartey, September 1991.

12 Mumuni 1994, 44.
} 
Council for Islamic Affairs, the Imam Husayn Foundation as well as the Nation of Islam.

In Ghana, Muslims are generally classified into Sunni and Ahmadi Muslims with the understanding that, with the exception of the Ahmadis, the rest of the Muslim population are Sunni. However, technically Sunnis are Muslims who adhere to any one of the four orthodox schools of Islamic law. The discussion will be limited to distinct Sunni groups in Accra. There exist in Accra several Islamic groups with insignificant doctrinal differences amongst them, in addition to the Sufi brotherhood, the Wahhabiya also known as the Ahlul-Sunnah, the Shi'ite and the Elijah Muhammad Islamic Brotherhood. It is significant to note that despite the doctrinal differences among Muslims in Accra, they are united in the mode of worship. There are no specific mosques for Wahhabī Shi ${ }^{3}$ ah and Sufi. It is worth nothing that, though an Imam of a particular mosque could be a Sufi, the congregation will be a mixture of Shi'ah, Wahhabī and Sufi. Islamic rituals have significance not only in their religious context but as a manifestation of a common social pattern. Islam as a way of life provides the necessary integration of both the individual and society.

The most dominant Islamic group in Accra and Ghana as a whole are the adherents of the Sufi brotherhood, namely the Qādirīya and the Tijānīya. The Qādirìya is believed to have been introduced by members of the Gold Coast Hausa Constabulary in the nineteenth century and Mallam Naino Iddris as well as his descendants and disciples are said to have belonged to the tariqa before joining the Tijānīya. Today the Qādirīya has been replaced with the Tijāniya in most places and the brotherhood has only a few adherents in Ghana. However, some elderly Muslims still belong to this order, among others Mallam Muhammad Awal at New Town in Accra.

The most popular Sufi order in Accra is the Tijāniya. The expansion of the order in Ghana started after 1889. According to Steward, it was one Alfa Hashim, who was a nephew of al-hājj Umar Tal and who took refuge in Madina in the first decade of the twentieth century, and Moro Futi, the elder brother of al-hājj Umar Tal, who were responsible for the introduction of the order in Ghana. ${ }^{13}$ The Tijāninga gained wide patronage after the decline of the Salaga market in Gonja and the dispersion of the Hausa traders and clerics to the coast and throughout northern Ghana during the 1890s. By far the most revered scholar is al-hạjj Umar of Kete Krachi, a Hausa who settled in Salaga in the 1870s. al-hājj Umar was considered the spiritual leader of the Gold Coast Muslims from the time of his pilgrimage in 1913 to his death in 1934. The Tijāniya received a further boost through the activities of the celebrated Senegalese scholar Ibrahim Niass of Kaolack in the 1950s. The impact of the order is manifested by the fact that all Imams of Accra, from Naino up to

13 Stewart 1965, 29. 
Uthman Nuhu Sharubutu, have all belonged to the order and have contributed to the development of the order in the country. ${ }^{14}$

Currently Shaykh Abdallah MayKano of Prang in Brong Ahafo is looked upon as the spiritual head of the Tijānīya in Ghana. MayKano is a former student and disciple of Ibrahim Nyass. Other leading Tijānī clerics in Accra are: Chief Imam Uthman Nuhu Sharubutu, Mallam Salisu Sha'ban at Nima, Kamalu-deen Abu Bakr (Deputy Chief Imam), Yahya Amin (Imam of Shukurah and chief disciple of Sharubutu), and Saani Murtala of the National Council of Ulama' at Nima. In terms of academic contributions, the most revered Tijānī scholars are Uztudh Abdul-Razak, a former lecturer at Ahmadu Bello University in Zaria, Nigeria, and Jamal Baba, Imam of New Town (Accra), both of whom graduated from the al-Azhar Islamic University in Cairo, Egypt. ${ }^{15}$

Wahhabī teaching has also influenced the Islamic practices of Ghanaian Muslims. In the 1950s and early 1960s, Ghanaian Muslims were exposed to various Islamic ideas, and the Wahhabiya was not an exception. This was enforced after the establishment of Arab and Islamic Missions and Embassies in Ghana after independence in 1957. Prominent among them were the Missions of Egypt, Saudi Arabia, Libya, Algeria, Lebanon and Pakistan. Ghanaian Muslim students were granted scholarships from these Missions to study in their respective countries. The majority of them returned with Wahhabi ideas and began promoting them in their communities. The first organised force in the dissemination of Wahhabiya was the Islamic Research and Reformation Centre at Nima. The founding clerics in 1972 were among others Haji Umar Ibrahim Imam, Haji Shu'ab Abu Bakr as well as Mallam Musah. All of them had studied in Saudi Arabia. ${ }^{16}$ The centre was aggressive in its missionary activities in Accra, particularly towards the dominant Tijānī Muslims.

Another organisation for the promotion of the Wahhabi doctrine is the Supreme Council of Islamic Affairs, an umbrella organisation for all Saudi trained graduates in Ghana. The Council is under the leadership of Dr. Ahamad 'Umar, who lives in Kumasi, and Dr. Sa'id Salis, a lecturer at Department of Modern Languages at the University of Ghana in Legon. ${ }^{17}$ The Wahhabiya is catching up steadily in Ghana with the youth due to its modern approach to Islamisation through awarding scholarships to the youth and establishing modern Islamic institutions of learning in the urban areas. It is also very active in most urban cities but yet to make a mark in the predominant rural communities. In Ghana, they are popularly referred to as Ahlus-Sunnah Wal Jamªt with Haji Umar Ibrahim Imam as their National Chief Imam.

\footnotetext{
14 Mumuni 1994, 47-49. See further Stewart 1965.

15 Mumuni 1994, 49.

16 Mumuni 1994, 52. The Arabic title al-hāajj is usually transcribed in Ghana as Haji or Alhaji and will be used throughout the text when used by Ghanaian Muslims.

17 Mumuni 1994, 52-53.
} 
Ghanaian Muslims came into direct contact with Shi'ism in 1982 when the Islamic Republic of Iran, which appears to be the custodian of Shi'ism globally, established its mission in Ghana. Earlier on, Ghanaian students in the Middle East and Ghanaians who studied in the Islamic Republic of Iran had contact with Shi'ism. Shaykh Ishaq of Mamobi in Accra, who studied in Lebanon, was one of the early Ghanaian Shi'ah. However, Shaykh AbdulSalaam al-Bansi, one of the pioneers to study in the Islamic Republic, is seen to be the pioneer Shi'ah in the country, probably due to his intimate relationship with Iranian Shi'ah institutions and the Cultural Consulate of the Islamic Republic in Accra. His contemporaries are Ibrahim al-Bansi and Baba Kamalu-deen. These pioneer Shi'ahs went to the Islamic Republic after studying in the Middle East. ${ }^{18}$

The Cultural Consulate of the Islamic Republic is the vanguard of Shi'ah propagation through its scholarship scheme, seminars and supply of Shi'ah literature in Accra. In fact, the Cultural Consulate of the Islamic Republic has during the 1990s become the most active one among the Muslim consulates in the country. In addition, the Imamiyyah Muslim Mission in Tamale as well as the Ahul-Bayt Institute and the Imam Husayn Foundation in Accra are Shi'ah institutions, which are very active in propagating the Shi ${ }^{3}$ ite doctrine. ${ }^{19}$ They have contracted a mosque opposite the Accra Girls Secondary School at Maamobi in Accra, where Shaykh Abdul-Salaam al-Bansi serves as Imam and Shaykh Ibrahim al-Bansi as his naib (deputy). ${ }^{20}$

The latest Islamic group in Ghana is the Elijah Muhammad Islamic fraternity or the Nation of Islam, an African-American Islamic organisation based in the USA. Ghanaians came into contact with the Nation of Islam in 1986 when Louis Farrakhan visited Ghana. Since then Farrakhan has become an intimate associate of the former President of Ghana, Flt.Lt. J.J. Rawlings and has visited the country in 1989 and 1993. The African office of the Nation of Islam is at Osu in Accra with Brother Akbar Muhammad as head of the African Secretariat and resident representative. The aim of the Nation of Islam is to contribute meaningfully to the social transformation of the country. Its focal point is to integrate the African-American Muslims into the Ghanaian environment. There are plans by the Nation of Islam to establish an AIDS educational and treatment centre at Nima and an educational complex at Weija, both in Accra.

\footnotetext{
18 Interview with Tahiru Kamara, Librarian at the Cultural Consulate of the Islamic Republic of Iran in Accra.

${ }^{19}$ Interview with Sebaway Zakariyya, official at the Cultural Consulate of the Islamic Republic of Iran in Accra.

${ }^{20}$ Mumuni 1994, 55-56.
} 


\section{The Origins of Non-Governmental Islamic Organisations}

Muslims played various roles in the social, economic and political life of the country in the pre-colonial and colonial period as well as during the struggle for independence and during the post-colonial period. The majority of these activities were, however, performed by Muslims as individuals and not by Muslim organisations. The few early Muslim organisations that were established had arisen from the need of the Muslims to co-ordinate their activities. For instance, the intimate association that existed between the Gold Coast Hausa Constabulary and the colonial government enhanced the formation of Islamic non-governmental organisations to champion the cause of Islam in Accra. In addition, Muslims experienced the impact and examples of Christian organisations such as the Catholic Secretariat, Methodist Church and Presbyterian Church of Ghana.

The first Muslim organisation to emerge was the Gold Coast Muslim Association (GCMA) in the 1930s. The initial objective of the GCMA was to cater for the social and religious needs of the Muslim community. The founders and the majority of its members were migrant Muslim settlers in the Gold Coast colony. The association exercised its influence through the ethnic unions, mainly Nigerian, and the marketing unions such as the butchers that were affiliated to it. Soon, however, it turned its attention to the national politics of the time. Prince is of the view that the association departed from its social objectives when it turned its attention to politics in 1939, when after the earthquake disaster in Accra, Muslims felt that there was an unfair distribution of building material. ${ }^{21}$ On the impact of GCMA, Prince comments:

The Gold Coast Muslim Association ... is a symbol of a movement which seems to have taken the rest of the country by surprise, for little attention was paid before that time to the political role of Muslims. They were usually forgotten or ignored. ${ }^{22}$

In order to enhance its political activities, particularly during the struggle for independence, the Gold Coast Muslim Association metamorphosed into the Muslim Association Party (MAP) in 1954.

The political activities of the Gold Coast Muslim Association led to the emergence of yet another Islamic Non-Governmental Organisation, the Muslim Youth Congress (MYC) in 1950.23 When the Convention People Party (CPP) came to power in Ghana, the leadership of the MYC came into prominence and gained political influence. Mallam Futa, a MYC functionary, was made the National Chief Imam when Muhammad Abass was removed from

21 Prince 1954, 107. See further Mumini 1994, 96-100.

22 Prince 1954, 104.

23 The Congress probably came into existence to champion the political cause of the Convention People Party (СРP) due to the anti-CPP stand of the Gold Coast Muslim Association. The CPP is believed to have fuelled the formation of the MYC to undermine the leadership of the GCMA and to curb its political influence in the country. The congress was vehemently anti-GCMA and a wing of the CPP. See further Denis 1964, 306. 
that office in 1959.24 The Muslim Youth Congress lost its political influence and became ineffective after the overthrow of the CPP in 1966.

In 1957, the Ghana Muslim Mission (GMM) came into existence. It was the first Islamic non-governmental organisation to champion the cause of indigenous Ga Muslims in Accra. The main goals of the mission were towards bringing all indigenous Muslims under one fraternity, revising the true teachings of Islam and catering for the needs of newly converted Muslims and providing educational facilities for the youth..$^{25}$

Since its inauguration, the GMM has been able to establish several educational institutions throughout the country, among them are over 20 preparatory and primary schools. In addition, the GMM has a school complex with a Mission hall and a mosque at Korle Gonno in Accra as well as an Islamic Secondary School in Kumasi, a secondary and commercial school at Gomoa Abasso in the Central Region and a girl's vocational training centre at Mankessim. However, the GMM relies heavily on financial assistance from Saudi Arabia. ${ }^{26}$

The National Liberation Council (NLC), which toppled the CPP Government on 24th February 1966, banned both the Muslim Association Party and the Muslim Youth Congress. The consequence of this action by the then Government led to the creation of the Ghana Muslim Community (GMC) in 1966. The GMC was a loose Islamic community dominated mainly by migrant Muslims from zongo communities in the Accra metropolis. The prominent members were migrant Islamic clerics, migrant businessmen and migrant Muslim chiefs. The various Muslim organisations, such as the Gold Coast Muslim Association, the Muslim Association Party, the Muslim Youth Congress, metamorphosed into the Ghana Muslim Community and became defunct after the emergence of the GMC. The Ghana Muslim Community was established for the promotion of Islam and the interest of Muslims. After the formation of the GMC, the Muslim community resolved to get out of national politics completely. Besides politics, the aims and objectives of the GMC were not different from those of the parent bodies. Eventually, the body turned into a Sufi motivated religious group and a majority of its members belonged to the Mālikī school of Law. ${ }^{27}$

The next development was the formation of the Council of Muslim Chiefs in Accra. Differences of culture and religious beliefs and the lack of recognition of the new institutions aimed at the maintenance of law and order and good governance by migrants in Accra led to the rise of ethnic headmen or

\footnotetext{
24 Imam Muhammad Abass came into prominence once again as he was reinstated as National Chief Imam after the 1966 coup and was succeeded by his son Mukhtar Abass. See further Mumuni 1994, 104-05.

25 Mumuni 1994,117-22.

26 Interview with Haji Kassim Quartey. See also Dretke 1968 and Mumuni 1994, 124.

27 Mumuni 1994, 105. However, the hegemony of the GMC was undercut three years later during the second republic by the promulgation of the Aliens Compliance Order of 1969. Some of the migrant settlers, particularly the Hausa and Yoruba, were affected by the order.
} 
chiefs. ${ }^{28}$ According to Chief Brimah Amida Peregrino, the Council of Muslim Chiefs was formed in December 1969 by some prominent ethnic chiefs in the Accra metropolis. ${ }^{29}$ The Council was composed of both the alien and national migrant chiefs although the alien chiefs dominated. ${ }^{30}$ The main objectives of the Council were to give advisory services to the Muslim community in Ghana, to serve as a rallying point for all migrant Muslim chiefs in Accra and to assist in the administration and maintenance of the mosque built by their ancestors. Five alien and four national migrant chiefs formed the Council. In order to ensure unity and satisfy the alien and national chiefs in the Council, the constitutional arrangement was that the ceremonial presidency went to the national migrant chiefs whilst the executive chairman went to the alien chiefs. The Council of Muslim Chiefs was to become a very powerful NGO due to its role in the selection of National Chief Imam and its intimate relations with the national political leadership. The Council more or less endorsed the ancient tradition of Brimah the butcher and his descendants having the duty of appointing the spiritual leaders for the Accra Muslim community. In order to create a balance, the descendants of Brimah the butcher nominate either a Hausa or a Fulani to the spiritual office. ${ }^{31}$

The Council of Muslim Chiefs has also been engaged in charitable activities, among others giving material support to victims of natural disasters. Each year the Council organises a durbar for the chiefs at Nima as part of the Id alFitr festivities. The main source of funds to the Council is through contributions from member chiefs and it is important to note the Council is at present one of the very few Islamic bodies that has nothing to do with the Arab and Islamic governments and their missions in Ghana as far as funding is concerned. ${ }^{32}$

\footnotetext{
28 Acquah 1972, 102. Ethnic headmen are nominally people with no secular education since there is a close correlation between illiteracy and the use made of customary institutions.

29 Interview with Chief Brimah Amida Peregrino, May 1993.

30 However, already at the beginning of its existence, there were rifts within the Council. When chief Musa Balago, a Frafra, was elected as the first president, some 'national' migrant chiefs, in particular chief Ibrahim Dagombe, a Dagombe, thought that his election was not in order. Instead, chief Ibrahim argued that one of the chiefs from the Northern region should have become president.

31 Interview with Haji Labaran Muhammad Ibrahim, General Secretary of the Council of Muslim Chiefs. See further Mumuni 1994, 108-13. The National Chief Imam is selected among all the ethnic imams as the representative of all imams in the country. However, because the 'alien' migrant chiefs have had more influence in the council due to their wealth or large following, Hausa imams in particular emerged as the Chief Imam. In most cases the selection of these imams is not based on scholarship.

32 Mumuni 1994, 116, 116-17. The council has for some years now been consulting with the National Chief Imam, the ethnic imams and some notable members of the ${ }^{\mathrm{c}} \overline{\mathrm{l}}$ lam $\bar{a}^{\mathrm{J}}$ to decide on the nisab (minimum amount of wealth) for the various properties which attracts zakät and also a minimum amount of mahr (dowry) for Islamic marriages.
} 


\section{Women Islamic NGOs}

Women have not been left out in the formation of associations. The first of such organisations was Zumunchi. The term is a Hausa word denoting showing love and fraternity. It is an Accra-based benevolent women's association which was formed in 1968 when a group of women met and one of them suggested the formation of an association. They then began to meet at Cowlane each contributing six pence weekly for a chair and a canopy. ${ }^{33}$ The aim of Zumunchi is to assist members in times of birth, death, marriage and, occasionally, sickness. It is found in Muslim communities in Accra such as Nima, Adabraka, Tudu, Accra New Town, Sabon Zongo, Madinah, Shukurrah, Cowlane and Alajo. However, Zumunchi has had a limited role in the dissemination of Islam because the organisation does not engage in inculcating Islamic practices and mode of worship into its members. Although open to all women Zumunchi has become an association of successful Muslim businesswomen, opinion-influencing Muslim women leaders and hajias (women pilgrims). ${ }^{34}$ It is worth noting that some ${ }^{\mathrm{c}} \overline{\mathrm{u}}$ lam $\bar{a}{ }^{3}$ in Accra have been critical about the activities of Zumunchi due to its emphasis on drumming and dancing.

The second women's association to be established was the National Assembly of Muslim Women. The Assembly was founded in 1981 and soon became influential in the Muslim community due to its intimate relations with the government of the Third Republic and with the Saudi Arabian Embassy. This status was due to the personal influence of its first president, Hajia Amina Baby Ocansey, who was also the women's organiser of the ruling political party (PNP). In 1984 the Assembly established a day nursery and preparatory Islamic school at Abeka in Accra. Initially, Saudi Arabia and Pakistan assisted the school with Islamic literature, while Egypt donated two teachers to the school. In the late 1980s, the Muslim World League emerged as the financial backbone of the school. In addition to the school, the Assembly gives financial assistance to institutions for handicapped children. ${ }^{35}$

During the middle of the 1980s there was an upsurge in the country of women's groups with different orientations, which led to the establishment of the Federation of Muslim Women Associations of Ghana (FOMWAG). It was an attempt to bring all Muslim women's organisations under one umbrella in order to have a unified front and to speak with one voice. The FOMWAG was inaugurated in December 1997. Its main objective is to make the Muslim

\footnotetext{
33 Pellow 1977, 77.

34 Mumuni 1994,126-27.

35 Interview with Hajia Amina Baby Ocansey, President of the National Assembly of Muslim Women 20th October 1992. See further Mumuni 1994, 127-32. During the early 1990s, the school had sixteen teachers and 770 pupils. However, since the mid-1990s, the Assembly has had difficulties in running the school as it has become short of funds, mainly due to the fact that Hajia Amina Baby Ocansey is out of business and there are no more funds forthcoming from Saudi Arabia. As a consequence, most teachers and pupils have left the school.
} 
woman conscious about her rights and responsibilities in Islam and empower her through education, to play a more positive role in national development. ${ }^{36}$

\section{The Islamic Councils}

In the discussion so far it is apparent that besides the women's organisations in Accra, ethnic and doctrinal solidarity played a vital role in the formation of Islamic non-governmental organisations in Accra. One of the basic divisions was the organisation along migrant lines and along indigenous lines. While the Ghana Muslim Community and the Council of Muslim Chiefs represented migrant Muslims, the Ga were represented by the Ghana Muslim Mission. Yet, despite these different lines of organisation, there have been attempts made by both the migrant and indigenous Muslims to have a united body to champion the cause of Sunni Muslims in Accra in particular and Ghana as a whole. Ideally, this united body was to be charged with the responsibility to unite and coordinate the activities of Sunni Muslims in the country. It is important to add that whilst in some instances the initiative came from the migrant and indigenous divide in some cases it came from the national government in power. The government usually intervened in Muslim affairs with the explicit aim of creating a congenial environment to enable Muslims to contribute their quota to national reconstruction and development. The various initiatives consequently resulted in the formation of Islamic Councils in Accra. These Councils are vested with a wider scope of activity than their component bodies.

The drive for a united national representation led over the years to the formation of eight Councils. What is interesting about the formation of these Councils is that almost every national government led to the formation of a new Muslim council. The Councils are the Muslim Council of Ghana (MCG), the Supreme Council for Islamic Affairs (SCIA), the Ghana Islamic Council (GIC), the Ghana Muslim Representative Council (GMRC), the National Islamic Secretariat (NIS), the Federation of Muslim Council (FMC), as well as the Dinil-Islam of Ghana (DIG).

\section{a. The formations of councils before 1972}

The first Islamic Council in the then Gold Coast, the Muslim Council of Ghana (MCG), was formed in 1953. The Council, which was to be the mouthpiece of Muslims, was formed on the advice of the Convention People Party (CPP) Government. The MCG was apparently formed by the CPP in an attempt to win Muslim solidarity and support. Although the Council was formed ostensibly to unite Muslims, Dretke is of the view that its creation rather brought

36 Ammah 1999, 3. 
divisions among Muslims in Accra. On the activities of the Council he comments that:

National politics created yet another division among Muslims in Accra. Since August 1953, there have been Islam and CPP mosques, Islam and CPP faithful. For the first time, the Id al-Adha prayer of August 1954 gave rise to two separate ceremonies.37

Muslims who shared different political views were debarred from its activities. The nucleus of the Council were the migrant Muslims. The Council came to a halt in 1966 after it had been banned by the National Liberation Council. ${ }^{38}$ In 1969, the Supreme Council for Islamic Affairs (SCIA) was established by some Ga Muslims and Muslims from the northern part of the country. Alhaji Abu Jaja, a Tamale based businessman became the chairman of an eight-member National Executive Committee elected from the Northern, Greater Accra, Eastern and Upper Regions. ${ }^{39}$ In 1973, the Supreme Council of Islamic Affairs became one of the three component bodies of the Ghana Muslim Representative Council. Thus, the SCIA existed as an independent body for only four years. ${ }^{40}$

Some years earlier, the Ghana Muslim Community and the Ghana Muslim Mission had formed a single loose body-the Ghana Islamic Council (GIC) in 1971. The aim of the GIC was to cater for the welfare of Muslims in the country. ${ }^{41}$ The need for the co-operation was probably due to an Accra High Court order to auction the national central mosque then under construction at Abossey-Okai in Accra but also due to efforts to ease the rivalry between the two bodies. ${ }^{42}$ However, barely two days after the inauguration of the GIC in 1972, the Executive Council of the Ghana Muslim Mission disassociated itself from the new Council. ${ }^{43}$ Prior to the inauguration of the Ghana Islamic Council, there were calls for the suspension of the inauguration of the Council on the grounds that those concerned had no mandate to speak for the Ghana Muslim Mission. The rush to form the Council at all costs despite the reservations of the Ghana Muslim Mission was probably to win the support of the new administration of the National Redemption Council under General I.K. Acheampong. The withdrawal of the Mission paralysed the activities of the new Council since it became only a Ghana Muslim Community affair. ${ }^{4}$

\footnotetext{
37 Dretke 1968, 85.

38 Mumuni 1994, 139-41.

39 Interview with Haji Kassim Quartey, June 1993 as well as "New Council for Muslims", Daily Graphic, 7/4/1970, 10.

40 See further Mumuni 1994, 141-42.

41 "Muslims to form new body", Daily Graphic, 7/10/1970, 16. However, the two component bodies were to operate as independent ones.

42 "Muslim Community Taken to Court", Daily Graphic, 23/9/1970, 4. The court order followed the failure of the Ghana Muslim community to pay Messrs. FAF (Ghana) Ltd., the firm building the mosque an amount of GHC 425,651.00 in respect of the construction of the mosque.

43 “New council criticised", Daily Graphic, 2/8/1972,4.

${ }^{44}$ Mumuni 1994, 143-44.
} 


\section{b. Attempts to create unity among the Muslims during the 1970 s}

The National Redemption Council (NRC) appointed in 1972 a national committee to settle all dispute among Muslim organisations in the country and to ensure Muslim Unity. ${ }^{45}$ The efforts of the NRC for ensuring peace and harmony among Muslim bodies gave birth to the Ghana Muslim Representative Council (GMRC). The GMRC was inaugurated in March 1973. It emerged as an umbrella body for all Muslims; the GMC, the GMM and the SCIA being its component bodies. The primary objective of GMRC was to liase with government to supervise the construction of the Abossey Okai central mosque, supervise $h \bar{a} j j$ operations, mediate in the appointment of and the dismissal of the imams and co-operate with government to promote education facilities for Muslims. ${ }^{46}$ The leadership of the Council was supposed to rotate among the three component bodies for a term of three years, whereas the National Executive Council was to include members from the component bodies. The leadership began with the Ghana Muslim Community and Alhaji Shardow Kudus, an Accra businessman, emerged as the first national chairman. Alhaji Mahmoud Lamptey (SCIA) became the first vice-chairman. The leadership of Shardow Kudus ended prematurely in July 1974 when the Executive Council was dismissed. A new Executive Council was appointed under the joint chairmanship of Alhaji (Major) B. Salifu and Alhaji Bashiru Kwaw-Swanzy. However, in 1976 Alhaji (Major) Salifi's and Alhaji KwawSwanzy's Council was dissolved by the Council of Muslim Chiefs and was replaced by an eight-member Interim Management Committee with chief Alhaji Kadri English as chairman. According to the chiefs, the reason for their action was the failure of GMRC to comply with the mandate given them in 1974 on assumption of office. ${ }^{47}$ A new National Executive Council of the

45 "Bid to Get Muslim Unity", Daily Graphic, 12/7/1972, 11.

46 See further Mumuni 1994, 144-45, 151-55. During 1978, the GMRC made an attempt to publish a magazine of its own, called The Muslims Horizon. Just around that time, the GMRC also instituted a body known as the Muslim Relief Organisation to assist victims of natural disasters and refugees. During 1985, the GMRC established a directorate-general for information and Islamic guidance to assist in the promotion of Islamic studies in Ghana. The GMRC is affiliated to several international Islamic organisations, among others the Muslim World League (Rabita), the Organization of Islamic Conference, the World Islamic Call Society, the World Islamic Information Services, and the Organisation for Islamic Unity for Africa.

47 "Muslim Affairs", Daily Graphic, 27/12/1976; "Muslim Executive", Daily Graphic, 17/1/1977. The action of the chief was a new dimension in the activities of GMRC because prior to that the chiefs had had no influence in the affairs of the council. One consequence of the chiefs action was that the migrant Muslims were not to take secular and spiritual power again. According to the chiefs, the executive council had not only failed to draft a constitution for GMRC, but it also failed to convene a national congress. The council was also criticised on the way and manner it had handled the 1976 häjj operation. Responding to the allegation, Alhaji S. Sibidow, the general secretary of the dissolved executive council in a press statement denied the allegations of the chiefs. He described their action as unconstitutional and an abuse of the intelligence and integrity of Muslims in the country. According to Sibidow, some people were associating themselves with the chiefs because they wanted to avoid refunding various sums of money they borrowed from the GMRC whilst in Jeddah, whereas others wanted to avoid accounting for five complimentary air tickets meant for distribution to regional Imams which they used themselves ("We are still in office", Ghanaian Times, 29/12/1976, 12). 
GMRC with Alhaji Dauda Otoo as its chairman was elected at a National Congress held at Cape Coast during March 1977. The National Muslim Council (NMC) participated in the Cape Coast congress as a component body. The NMC had been formed by 'national' migrants of the Supreme Council for Islamic Affairs and their colleagues in Ashanti and Eastern regions. However, shortly after the Cape Coast congress, the Ghana Muslim Community, one of the component bodies of the GMRC, expressed its dissatisfaction with the activities of the newly elected National Executive Council. Consequently, the GMC disassociated itself from the GMRC in protest probably either because Otoo was a tubah (convert) or due to the admission of the NMC as a component member.

\section{c. New rifts and rivalries between Muslim councils}

The withdrawal of the Ghana Muslim Community from the GMRC during 1977 had adverse consequence on the credibility of the latter when the GMC started to create its own network. A new Islamic Council named the United Ghana Muslim Representative Council was formed in Accra in 1984. The UGMRC was to be run by an Interim Management Committee for three months with Alhaji Mukhtari Abass, who at that time was the National Chief Imam, as its chairman. ${ }^{48}$ The founders of the UGMRC alleged that the main objective was to unite all Muslim groups in the country and the disclosure that the Ghana Muslim Representative Council was dissolved due its refusal of persistent appeals to render accounts of its stewardship since 1973.

Meanwhile in 1984, the National Executive of GMRC had admitted six 'indigenous' organisations into its membership, thus bringing the membership to ten. ${ }^{49}$ The sudden expansion of the membership of the GMRC brought some mixed feelings to Muslims probably because the expansion came just two days after the formation of the new United Ghana Muslim Representative Council. Moreover, the new bodies were alleged to be 'indigenous' organisations undermining the status of the GMRC as the mouth-piece of all Muslims in the country. In addition the GMRC did not make any effort to have a representation from the 'alien' African migrants. As a consequence, the GMRC appeared indigenous in outlook. What is more, the GMRC dismissed Alhaji Mukhtari Abbas as the Chief Imam, accusing him of associating himself

48 "New Muslim Council formed”, Daily Graphic, 16/4/1984, 5. The component bodies of the new Council were the Ghana Muslim Community, the Ansaru-Din-il-Islamiyya, the Islamic Research and Reformation Centre, the National Council of Ulama and Imams, the Council of Muslim Chiefs as well as the Association of Muslim Elders.

49 "GMRC. News Statement", Daily Graphic, 25/4/1984, 4. The new members were the United Muslim Association of Ghana, the Ghana Islamic Propagation and Jihad, the Islamic Study Group, the Jihad Muslim Conference, the Assemble of Ghana Muslims as well as the United Muslim Association of Ghana. 
with the new United Ghana Muslim Representative Council. This state of affairs brought deeper repercussions within the Muslim Community. ${ }^{50}$

\section{d. Libyan attempts to create unity}

The rivalry between the Ghana Muslim Representative Council and the United Ghana Muslim Representative Council led to calls for peace and unity among the Muslim Community from individuals, Islamic institutions, Islamic and Arab Missions as well as from the Government. ${ }^{51}$ These pleas contributed ultimately to the signing of an accord between GMRC and UGMRC on 7 July 1985 in Accra. The accord culminated in the formation of yet another new body, the National Islamic Secretariat as an umbrella body for all Islamic organisations in the country. The component organisations of the Secretariat were ten: five from GMRC and the other five from the UGMRC. Alhaji Dauda Otoo and Mr. B.A.R. Braimah (Deputy National Chief Imam and Senior Lecturer at the University of Ghana) respectively emerged as the two national coordinators of the new Secretariat.

During the first year of its existence, the National Islamic Secretariat received assistance from Libya. In December 1984, the Libyan leader $\mathrm{Mu}^{\mathrm{c}}$ ammar al-Qadhdhāfí visited Ghana and appealed to the leadership of the Secretariat to ensure unity among Muslims. He also pledged his country's preparedness to provide financial assistance for the promotion of Islam in Ghana. ${ }^{52}$ In addition to Libya, the Secretariat received support from the Islamic Republic of Iran.

Along the way, the National Islamic Secretariat was transformed a few years later into the Federation of Muslim Councils. The transformation was an outcome of negotiations conducted by the Ghanaian delegation at the Third International Islamic Conference of West African countries that was held in Tripoli during January 1987. The Ghana delegation in connection with the World Islamic Call Society (WICS) held a series of discussions about Muslim unity in Ghana which eventually led to the signing of an agreement between the Ghanaians and the World Islamic Call Society, referred to as the 'Tripoli Accord'. Among other things, it was agreed that the name Nation Islamic Secretariat was to be changed into Federation of Muslim Councils. ${ }^{53}$ Funds were

\footnotetext{
50 Mumuni 1994, 149-50.

51 Among others, Hajia Anima Baby Ocansey, President of the National Assembly of Muslim Women, urged Muslims to promote Islam instead of organising rival bodies to create confusion in the Muslim community ("Muslims", Daily Graphic, 2/5/84, 5). The Royal Embassy of Saudi Arabia in Accra added its voice for peace and unity among Muslims. The ambassador appealed to all conflicting Muslim institutions to bury their differences and unite in order to give truth its rightful place. He also expressed his willingness to receive representatives of all the groups involved at his chancellery in an attempt to resolve the problem ("Muslims", Daily Graphic, $11 / 5 / 84,5)$.

52 "Gifts to National Islamic Secretariat", Daily Graphic, 2/2 / 1987, 2.

53 Tripoli Accord, translated into English from Arabic by Mr. B.A.R. Braimah. Other features of the accord were that in each of the ten regions of Ghana there would be a local Islamic council
} 
provided by the WICS for the initial setting up of a secretariat of the Federation and Alhaji Dauda Otoo was nominated as the first national coordinator of FMC. During 1989, the president of GMRC, Alhaji Abdallah S. William, became the acting coordinator due to Otoo's illness. In fulfilment of its earlier pledges and in order to facilitate the activities of the Federation, the WICS donated a Nissan Patrol jeep to the Federation. The Federation is affiliated to the World Islamic Call Society and the Muslim World League. ${ }^{54}$

\section{e. Law 221 and further rifts among the Muslims}

The government of Ghana passed a law during 1989 for the registration of religious movements. It was an attempt at surveillance of the various religious organisations due to the upsurge of new religious movements in the country. The 1989 Religious Bodies Registration Law under PNDC Law 221 required all religious bodies in the country to register with the National Commission on Culture. In addition, the registration aimed at investigating the number of religious movements in the country, their teachings and founders. Consequently a Religious Affairs Committee was set up under the National Commission on Culture for accomplishing the task. ${ }^{55}$

Law 221 posed a problem for the Muslim community due to the constant conflicts and disunity among its leadership. A series of meetings were held to see how best to comply with the law. In one of the meetings, Mr. B.A.R. Braimah proposed the establishment of yet another religious body, called Dinil-Islam or The Religion of Islam. His idea was that only Dinil-Islam should be registered since all Muslims in Ghana believe and practise Islam. The suggestion was taken in utmost good faith with the understanding that DinilIslam would cover all Islamic bodies and all Muslim places of worship in the country. ${ }^{56}$ A constitution was therefore promulgated on 11 October 1989 in compliance with the formalities for registration. The National Chief Imam, Uthman Nuhu Sharubutu, was made the overall head of Dinil-Islam of Ghana (DIG). The organisation received its certificate a few months later.

The registration of Dinil-Islam of Ghana was, however, seen by the Federation of Muslim Councils as an attempt to undermine its status as the sole mouthpiece of the Muslim community. As the legitimate umbrella organisation for Muslims in the country, the FMC also applied to the Religious Affairs Committee for registration. The committee therefore convened a meeting and

with a president, who would be a member of the general federation in Accra. Further that the general federation should cooperate with Islamic bodies and institutions in matters concerning Islam.

54 Mumuni 1994, 158-62.

55 Religious Bodies Registration Law, 1989, PNDC, L 221.

56 Letter dated 19 August 1990 at Religious Affairs Department, signed by Shaikh Uthman Nuhu Sharubutu to Justice D.F. Anna, “On misconception being harboured against Dinil-Islam of Ghana by the Executives of the Federation of Muslim Councils since its registration". Filed at the Religious Affairs Department, Department of the National Commission on Culture, Accra. 
invited representatives from both sides as well as Mr. Braimah to resolve the issue of two registrations for one religious body. At the meeting, Mr. Braimah defended his initial suggestion and explained to the panel that the FMC covered only ten organisations and as such was inadequate to represent all Islamic bodies and Muslim places of worship throughout the country. However, the representatives of the FMC issued a warning and stated that there would be more confusion among the Muslim community if the FMC was not registered. Due to these threats, the FMC was also registered. ${ }^{57}$ Since its registration, the DIG has mainly been active in organising lecture series and seminars as well as launching social welfare projects. ${ }^{58}$

At present, the GMRC, the FMC and the DIG are running concurrently. ${ }^{59}$ However, as far as the Government is concerned, only the FMC represents the Sunni Muslims in the country. Despite all the efforts made for a united national Muslim body for Sunni Muslims, political considerations and affiliation of the individual actors as well as the division of the Muslim Community into alien and indigenous Muslims and struggle for a religious leader at the national level as opposed to a secular one have all so far contributed to the non-existence of such a body. In addition, the influence of foreign interests has undermined the drive for a national representation for Sunni Muslims.

\section{The Impact of Islamic Councils on Muslims}

Since the first republic to date, the Islamic Councils, which have been discussed above, appear to be national in character although their main playground is in Accra. The component bodies of these Councils as well as their leadership are always in Accra, which has been criticised by Muslims, particularly those in the regions. What usually makes these Councils from one time to another national in orientation and character is the recognition given to them by the government in power as well as foreign interests.

Another critical issue has been the entrenchment of some officials as permanent executives in the Councils. In most cases they never returned to their mother organisations once they joined the councils. The GMRC, for ex-

\footnotetext{
57 Letter D.I.G/P.N.D.C/COS/90-1, dated 13/1/91, "Petition of the Muslim Ummah against the registration of the Federation of Muslim Councils as a religious body for Muslims". Filed at the Religious Affairs Department, Department of the National Commission on Culture, Accra. However, the Dinil-Islam petitioned against the registration of FMC and underlined that the registration of Dinil-Islam was final and for that matter there was no need for the registration of FMC because no Ghanaian Muslim would say that his religion is the 'Federation of Muslim Councils'.

58 Mumuni 1994, 162-64.

59 The Muslim Council of Ghana (MCG), the Supreme Council for Islamic Affairs (SCIA) and Ghana Islamic Council (GIC) as well as the UGMRC are all now defunct councils. A new Supreme Council for Islamic Affairs was established some ten years ago by Ghanaian Saudi trained graduates. Its head office is at Nima in Accra. This organisation, however, is the umbrella organisation for the Ahlul-Sunna in Ghana (Mumuni 1994, 180 fn 42).
} 
ample, was a composition of the Ghana Muslim Community, the Ghana Muslim Mission and the Supreme Council for Islamic Affairs. In effect, the officials of the GMRC were on secondment from these three organisations. However, most officials from the Ghana Muslim Mission and Supreme Council for Islamic Affairs never went back to their mother organisation after their tenure ended. The case of Dauda Otoo serves as a good example. In 1973, Dauda Otoo was the second deputy chairman, then became the first deputy chairman in 1974, and in 1977 he became the chairman of the Ghana Muslim Representative Council. When the Ghana Muslim Representative Council merged with the United Ghana Muslim Representative Council in 1985, Dauda Otoo became the first chairman of the National Islamic Secretariat. Again in 1987, when the Federation of Muslim Councils was formed, Otoo became the first coordinator of the Federation.

In effect Alhaji Dauda Otoo remained in power from 1977 to 1990 when he became bedridden. However, Otoo's leadership of the Ghana Muslim Representative Council limited the scope of the Council to become the representative of the indigenous Muslims in Accra that is, the Ga and the 'national' migrant Muslims. Among other things, it was during his administration in 1978 that the National Muslim Council, which was dominated by 'national migrant Muslims, was admitted into the GMRC after the withdrawal of the Ghana Muslim Community. By the end of Otoo's administration the GMRC was reduced to becoming only the mouthpiece of the indigenous Muslims in Accra.

Constitutional procedures were often ignored by some of the leading officials. For example, Article 3 of the GMRC constitution clearly states that: "The council shall remain strictly neutral in partisan political affairs and chieftaincy matters." Yet some former leading members of the GMRC officially and openly declared that the Council owed nobody any apology for their stand on "Union Government". Yet, as Alhaji S.M Sibidow once stated, the GMRC should be by its composition the political mouthpiece of Muslims in the country. He also believed that the Council was more or less a kind of a "Trade Union Congress" for Muslims. ${ }^{60}$

However, the main problem of the Councils has been their financial impropriety. Again, the GMRC serves as a good case study. Although Article 25, sub-section 3 of the GMRC constitution stated that "All disbursement from the funds of the Council must be approved by three-quarters majority of the National Executive Committee," there were occasions where huge sums of money in foreign exchange were disbursed by Alhaji Sibidow alone. For instance, during the 1978 ha $\bar{a} j$ season, the Bank of Ghana allocated some USD 31,500 to the GMRC, but Sibidow disbursed the money as he chose to. After the $h \bar{a} j j$ operations, he could only account for some USD 20,000. There is

60 Musab Ben Ahmad, "GMRC statement", Daily Graphic, 23/3/1977, 6. Sibidow was also criticised by Ahmad for pushing aside the constitution and redefining it without any amendment. Sibidow was said to have issued directives through the press usually without consultation with the other executives. Even worse, he had banked and disbursed the GMRC funds alone, pushing aside the treasurer and the financial controller. He had kept the post office box key of the council to himself and had alone decided what correspondence should be brought to the attention of the executive council. 
documentary evidence that Sibidow travelled to Saudi Arabia and personally acknowledged the receipt of an amount of USD 9,000 donated to the GMRC by the Organisation of Islamic Conference. The entire Executive Committee had no idea about the transaction. ${ }^{61}$ Already in 1979, Musab Ben Ahmad, who was the main critic of Sibidow, pointed out that despite the huge sums of money paid to the GMRC, no single educational, social or economic project had been undertaken and nobody was fully aware of the Council's state of accounts. ${ }^{62}$ Alhaji Sibdow was one the General Secretaries of the Ghana Muslim Representative Council. Although such critical observations were made as far back as 1979, the situation had not changed during the 1990s. ${ }^{63}$

A further problem of the GMRC as well as other Councils has been their lack of a secretariat. There is an office in Adabraka, which first housed the GMRC, the National Islamic Secretariat and currently the Federation of Muslim Councils. This office, however, is according to Musab Ben Ahmed nothing more than a meeting hall. For a long time, the permanent administrative staff of the various Councils did not report for duty and there was no filing or meaningful record keeping. As a consequence, letters and documents were almost always classified as confidential and kept at home. Also, for a long time there was no office equipment and the Adrabraka office was often closed until the $h \bar{a} i j$ season approached. ${ }^{64}$ In 1991, however, things slowly changed when the Council of Muslim Chiefs appealed to the government for assistance in the establishment of a secretariat for the Federation of Muslim Councils.

Another critical matter is the failure and inability of the Islamic Councils to unite the different Muslim factions. Therefore various political leaders, such as president Hilla Limann in 1981 and Flt. Lt Jerry John Rawlings in 1991, have called on the Muslims to close their ranks and come together since Islam is a religion of peace and unity. ${ }^{65}$ Neither have the Councils been able to correct the prejudices of Ghanaians against Muslims. Muslims are said to be actively involved in anti-social activities, such as smuggling, hoarding, blackmarketing, currency trafficking and armed robbery. For example, in his 1980 Id-al-Fitr address, president Limann declared: "I sincerely hope that after thirty days of fasting, you would be in a position to eschew all forms of antisocial activities ... which should be eradicated by all means from our social,

\footnotetext{
61 Musab Ben Ahmad, “GMRC. Statement”, Daily Graphic, 23/3/1979, 6.

62 “Ben Ahmed Resigns", Daily Graphic, 27/11/1979, 3. He further noted that if one observed the multitude of Muslim girls being deprived of schooling in favour of groundnut selling, the great number of Muslims among the unskilled labour force, the slum conditions under which Muslims live in the zongos in Accra, one could not but feel concerned. Ironically, he stated, these were not on the agenda of the very people who claimed that they were the champions of Muslims.

63 As to the GMRC, the supervision of the Council of Muslim Chiefs leaves much to be desired, too. The Council does not go through the audit reports and, if possible, does not prosecute offenders before a new executive takes office. Furthermore, the Council of Muslim Chiefs does not screen office holders and also does not arrange a proper handing over to the new executives.

64 Musab Ben Ahmad, "GMRC Statement," Daily Graphic, 23/3/1979, 6.

65 See "Muslims Must Unite", Daily Graphic, 3/8/1981. 1, and "Ensure Islam Remains Religion of Unity", Daily Graphic, 16/4/1991, 1.
} 
economic, political and spiritual life."66 In similar vein Flt. Lt Jerry Rawlings in 1979 had already warned the Muslim community: "You Mallams and Alhajis should not hide behind Islam and smuggle salt, Kola, timber and diamonds out of the country" and noted that Muslim communities such as Zongo Lane, Cowlane, Tudu and Darkuman had become a World Bank where almost every currency was exchanged for the cedi at an inflated rate. ${ }^{67}$

To a large extent, the Councils have failed to achieve most of their aims and objectives. They have woefully failed Muslims in Accra in particular and Ghanaians at large in their bid to uplift the socio-economic status and conditions of Muslims. In addition, the traditional role of the Council as the organiser of the annual hâajj is gradually fading away as the appointment and supervision of the Hajj Committee has been taken over by the National Commission on Culture and not the Federation of Muslim Councils since 1993. On the other hand, the Islamic Councils have tried to play an active role in Ghanaian society. They have organised prayer sessions for the success of the various governments and issued statements on Muslim festivities.

\section{Conclusion}

In spite the fact that 'alien' African and national migrants and the indigenous Muslims are the three main groups that make up the Accra Muslim community, the national migrants seem to be pushed to the margins by the 'alien' Africa migrants and the indigenous Muslims in Islamic activities in Accra. There are very few 'national' migrant controlled Islamic Organisations in Accra, the only one being the National Muslim Council, which was formed during 1979. Several reasons may be attributed to the marginalisation of the national migrants in Accra. First, there exists a strong social relationship between the national migrants and their kinfolk in the northern part of the country. Unlike the 'alien' African migrants, the national migrants regularly visit their home region and relatives there. Second, due to the close contact with their home regions, the national migrants pay little attention to their ethnic heads and religious leaders in Accra. Third, the national migrants usually regard their stay in Accra as only a temporary one as they hope to return to their home region and relatives as soon as possible.

The formation of Islamic organisations and councils has been influenced by ethnic and regional motives but also through the influence of government and foreign action. In the pre-1972 era, Islamic organisations in Accra were fluctuating in their numbers. Between 1930 and 1966, five organisations were officially known in Accra. However, the number was reduced to two between 1966 and 1968, but increased to three between 1968 and 1972. After 1972, the

66 “Muslims Must Unite," Daily Graphic, 14/8/1980,1.

67 "Don't Hide behind the Islamic Faith", Daily Graphic, 28/7/1979, p. 1. 
number of Islamic organisation has been increasing rapidly and brought about the proliferation of Islamic organisations in Accra.

The activities of the pre-1972 organisations were domestic and national in character and orientation. They were actively engaged in social, economic, religious and political matters. However, the roles and activities changed in the post-1972 period to become more international in their outlook. The major concern was to secure funds from Arab and Islamic governments and institutions, to get scholarships to go abroad for their members, to attend international seminars and conferences, to organise the annual pilgrimage to Makkah well as to serve as representatives of international Islamic bodies in Ghana.

Islamic organisations have tried to uplift the socio-religious status of Muslims in Accra in particular and Ghana as a whole. They have provided decent places of worship and have maintained modern structures for the education of the youth. Further, through the existence of scholarships, Ghanaian students have been able to study in the Arab and Islamic world. Another effort of the Islamic organisations has been to upgrade the ability of Muslims in reading and understanding Arabic. The organisations, especially those concerned with the social well being of Muslims, though not discussed in this study, have also cooperated with the Ghanaian government in the social, economic and political advancement of the country. It is of much relevance to also mention that the Sufi fraternities have played leading and important roles in the origins and development of Muslims NGOs in the country. They have specifically monopolised the Imamate in the country.

However, the Islamic organisations and especially the various Islamic Councils, have done very little in the campaigns against teenage pregnancy, drugs abuse, AIDS, and environmental pollution. Neither are Islamic organisations actively involved in organisations such as the Ghana Journalists Association or the Pan-African Writers Association. They also lag behind other religious bodies in assisting victims of stress, particularly refugees, Ghanaian returnees, and flood and disaster victims. Despite the efforts to promote Islam and social welfare of Muslims in Ghana, much is still expected from the organisations, in particular the various Islamic Councils. Islamic organisations, unlike other religious bodies, are not at the forefront in the fight against national social concerns. 


\section{References}

\section{Interviews}

Hajia Amina Baby Ocansey, President of the National Assembly of Muslim Women, October 1992.

Chief Brimah Amida Peregrino, Yoruba Chief in Accra, May 1993.

Haji Labaran Muhammed Ibrahim, General Secretary of the Council of Muslim Chiefs.

Sebaway Zakariyya, official at the Cultural Consulate of the Islamic Republic of Iran in Accra, March 1993.

Haji Suleyman Kassim Quartey, Vice National Chairman, Ghana Muslim Mission, June 1993.

Tahiru Kamara, Librarian at the Cultural Consulate of the Islamic Republic of Iran in Accra, November 1992.

\section{Newspapers}

Daily Graphic

Ghanaian Times

\section{Literature}

Ammah, Rabiatu (1999). Concretizing and Empowering Ghanaian Muslim Women for National Development. Insitute of African Studies, Columbia University, USA.

Acquah, Irene (1972). Accra Survey, Accra.

Anderson, J.N.D. (1978). Islamic Law in Africa. 2nd ed, London.

Clarke, Peter B. (1982). West Africa and Islam, London.

Dennis, Austin (1964). Politics in Ghana: 1946-1966, Oxford.

Dinan, C. (1975). "Socialization in an Accra Suburb, the Zongo and Its Distinctive Sub-Culture", Legon Family Research Papers, 3, Institute of African Studies, Legon; 45-62.

Dretke, James (1968). The Muslim Community in Accra. Unpublished M.A. thesis, I.A.S, University of Ghana, Legon.

Mumuni, Sulemana (1994). Islamic Organizations in Accra: Their Structure, Role and Impact in the Proselytization of Islam. Unpublished M.Phil thesis, Religions, University of Ghana, Legon.

Opoku, Asare K. (1977). "Religion in a Dormitory Town”, IAS Research Review, 4:2, Legon, 90-91.

Pellow, Deborah (1977). Women in Accra: Option for Autonomy, Michigan.

Prince, J.H. (1954). "The Role of Islam in the Gold Coast Politics", Journal of the West Africa Institute of Social and Economic Research, 3, Ibadan, 104-11.

Stewart, C.C. (1965), The Tijaniyya in Ghana. Unpublished M.A. thesis, I.A.S., University of Ghana, Legon.

Trimingham, J.S. (1959), Islam in West Africa, London. 


\title{
CHAPTER VIII \\ The Concept of Islamic Economy as Articulated in Sokoto
}

\author{
Social Justice and State Responsibility ${ }^{1}$
}

Holger Weiss

\section{Introduction}

The fiscal crisis of the state which has limited its possibilities for providing basic social welfare in developing countries during the last decades of the twentieth century is well-known. Although the European colonial powers had laid the ground for various public welfare and modernisation projects, due to several reasons, these projects had not achieved their aim, namely that of generating an improvement in the basic welfare standards of the former colonies. Some former colonies, such as Algeria and Egypt, tried various forms of state capitalism which, by the late 1970s, it had become ineffective to develop. Others, such as Nigeria as well as a number of other African states, attempted to develop a market oriented capitalism with little or limited state intervention. Here, also, the problems soon became overwhelming. ${ }^{2}$ Whereas there was some initial success in some of these states, especially with regard to economic prospects, from the late 1970s onwards any success was overshadowed by an ever-expanding population, urbanisation and decline of the public sector as well as general deterioration, corruption and even state collapse as in Somalia and former Zaire.

Most sub-Saharan African countries officially attempted to implement modified versions of socialism or state capitalism. However, since the 1980s, they have come under the pressure of the World Bank and IMF Structural Adjustment Programmes to open their economies. Thus, private enterprise was to be promoted by lifting regulations and the public sector was to be cut down to provide a mere minimum of basic services. Unsurprisingly, the social cost of both the deteriorating condition of economics and public services in parts of the South has been an ever increasing number of poor people.

One response towards the crisis in the South has come from 'Islamic economists'. Initially providing a critical voice against colonialism, the colonial state and the colonial economy during the first half of the twentieth century, Islamic economists have tried to explain and address economic problems as

1 An earlier version on this study was presented at the 1999 Helsinki workshop.

2 Cowen and Shenton 1997, Deegan 1996, Mason 1997. 
well as provide an 'Islamic' solution to poverty in predominantly Muslim countries. The general line of argumentation of the various Islamic economists has been to provide scope for individual economic initiative and markets, just as proponents of economic liberalisation do, but without losing sight of the responsibilities of the state and the public sector. ${ }^{3}$

Much of the debate of the Islamic economists has been directed towards the Middle Eastern countries and, in their view, the imperfect functions of the state and economy. ${ }^{4}$ However, Islamic economics had since the 1940s already taken the double role of being both a critical system of that thought as well as a political tool. Thus, at the end of the twentieth century, one can find advocates of Islamic economics both among official representatives of the governments as well as among the various Islamist political groups. Islamic economics has become an academic subject in some Muslim countries, such as Pakistan, Malaysia, Egypt and Saudi Arabia, ${ }^{5}$ while comprising the cornerstones in the argumentation of the Islamist movements in Egypt and Algeria. In some cases, such as in the Sudan as well as in Pakistan and Malaysia, governments have tried to implement various forms of Islamic economics. ${ }^{6}$ There is, however, no uniform concept of what constitutes an Islamic economy. Whereas most of the writings of the early Islamic economists, such as Sidiqqi and Qutb, rejected Western economic models and tried to establish an Islamic economy based on a return to Islamic values and ethics, modern Islamic economists have rejected in turn the 'revivalist' model and attempted to come to terms with Western economic theory without losing their genuine Islamic concepts of faith. ${ }^{8}$

Until the early 1980s, the discussion among Islamic economists was concentrated within the Middle East, Pakistan and the Sudan. Due to the impact of the Iranian revolution of 1979, there has been a world wide upsurge of the subject. Harvard-trained economists, such as Ziauddin Ahmad and some economists of the World Bank, turned towards Islamic economics and made it more 'fashionable'. ${ }^{9}$ Although Islamic economics had always been presented as a 'third way', being situated between laissez faire capitalism and socialism, it was hereafter presented as an Islamic welfare state policy. ${ }^{10}$ Since the 1980s, however, Islamic economics has also been debated in African

\footnotetext{
${ }^{3}$ Pfeifer 1997, 155. See also Ahmad 1980b.

4 El-Ghonemy 1998, 49-52.

${ }^{5}$ Ahmad 1980a, XVIII.

6 See further Saleh and Ngah 1980; Ba-Yunnus 1980; Scott 1987; El-Battahani 1996a; ElBattahani 1996b.

7 Siddiqi 1948; Qutb (Kotb) 1953.

8 Among others as-Sadr 1983; Mannan 1988; Chapra 1992.

${ }^{9}$ See further Ahmad 1991

10 Naqvi 1981, 80. According to Naqvi, the difference between a Western and an Islamic welfare state is that in the former the welfare state doctrine, namely 'from everyone according to his ability to everyone according to his need', has not been established according to the 'unitary concept of life', which is perceived as being original to Islam. By Naqvi's definition, the 'unitary concept of life' makes ethics the point of departure of an Islamic view on economics.
} 
Muslim countries, being closely linked, on one hand, with the politicisation of Islam and, on the other hand, to the Islamisation of society. The outcome of the rise of various Islamist movements has been the demand for the implementation of Islamic law and economics. ${ }^{11}$

Among African countries, Nigeria occupies a special position. It is the most populous of the African countries and has the largest Muslim population in Sub-Saharan Africa. ${ }^{12}$ However, due to its colonial history, it is unlikely that Nigeria can ever become a 'true' Muslim country, since roughly half of its population are non-Muslims. Thus, according to the Nigerian constitution, the country is a secular state. Yet, with the political and economic history of Nigeria, one which has been marked by military coups d'état and military rule between 1966 and 1978 as well as 1983 and 1999, and the collapse and erosion of the Nigerian economy since the late 1970s, voices among some Nigerian Muslim scholars have been raised for a total rejection of the secular state and a total Islamisation of the society as well as the economy.

The aim of this study will be to concentrate on one of the Nigerian proponents of the Islamisation of Economics in Nigeria, namely Sule Ahmad Gusau and the 'Sokoto School of Islamic Economics'. ${ }^{13}$ The reason for choosing Gusau and his writings as a case-point is mainly due to the fact that he is one of the few Nigerian academics who has published in the field of Islamic economics during the early 1990s. Unfortunately, at the time of updating this paper (August 2001), I have not been able to follow up Gusau's later argumentation about the subject. Neither was I able to follow up the development of Islamic economics as an academic subject at Usmanu Danfodiyo (Sokoto) university. Instead, I have been able to locate some of Sanusi Lamido Sanusi's contributions to the Nigerian debate about the implementation of an Islamic economy in (Northern) Nigeria during 2000 and 2001. As such, Sanusi's papers represent an interesting continuation of the older "academic" debate during the early 1990s. Sanusi's arguments are presented in a postscript at the end of the article.

\footnotetext{
11 See further Hallencreutz and Westerlund 1998, 4-6 as well as the case-studies by Stenberg 1998 and Loimeier 1998. For a general overview on the politicisation of Islam in Sub-Saharan Africa, see Hunwick 1997, 28-54. For an account of the rise of Islamism in Africa and the various reasons for it, see Westerlund 1982, Westerlund 1997 and Hodgkin 1998.

12 In fact, the Muslim population of Nigeria would count as the seventh largest Muslim community, after Indonesia, Bangladesh, Pakistan, India, Turkey and Egypt.

13 Due to limits of space, there is no possibility to further elaborate on the whole Islamisation process in Nigeria. A very good introduction to the subject, as well as the various debates within the Muslim society of Northern Nigeria since the colonial period up to the mid-1980s, is presented by Loimeier 1997. Steed and Westerlund 1999 provide a general outlook of the intraMuslim as well as Christian-Muslim conflicts and the rise of Islamist movements in Nigeria. On the general political as well as economic development of Nigeria since independence, see Osaghae 1998.
} 


\section{An Outline of the Concepts}

The creation of an Islamic state is perceived by Islamic economists as the precondition for the implementation of an Islamic economy. As long as none of the existing Muslim states can be regarded axiomatically as an Islamic State, Islamic economics cannot deal as a subject with a particular real situation. Rather, Islamic economics concentrates on the morals, ethics and ideals of a future Islamic state. Islamic economics, therefore, is normative according to its fundamental conception. Thus, Islamic economics can be used as an 'Islamic' critique of the unsatisfactory political, economic and social conditions in Muslim states and Muslim communities. A clear distinction is made by the advocates of Islamic economics between the actual conditions in Muslim states and the would-to-be situation in an Islamic state. None of the contemporary Muslim states are considered by the advocates of Islamic economics as Islamic states, since they were constructed on the basis of Western secular ideas of the nation-state and as such are the inheritors of the colonial system. Firstly, the $\operatorname{shari~}^{c} a$ is applied only to some limited extent in any of the Muslim states. Secondly, almost all of the Muslim regimes are considered to be corrupt. Thirdly, a fact which is crucial for the argumentation of the Islamic economists, Western economics, be it capitalism or socialism, is labelled as secular and thus is in contradiction to the teaching of Islam.

According to the Islamic economists, religion has to be the basis of the society as a whole and the source of ethical values in particular. Further, ethics should dominate economics, or as the Islamic economist Syed Nawab Haider Naqvi ${ }^{14}$ stresses:

The Islamic perception of socioeconomic process is dynamic and its insistence on social justice is uncompromising. This is because injustice disrupts social harmony and, for that very reason, is unethical. To produce the best social structure, according to this view, man's economic endeavours should be motivated by a meaningful moral philosophy. 15

The moral philosophy that Naqvi has in mind is Islam. However, contrary to the pre-modern discussion and disputes among Muslim scholars of Islamic jurisprudence, the late twentieth century debate among Islamic economists, in a sense, has reopened the field of applied Islamic ethics. Thus, Naqvi, among others, argues that Islamic ethics has to be transformed into a non-trivial, irreducible set of axioms to make Islamic ethics more universal. Naqvi introduces four axioms, namely unity, or the vertical dimension between Allah and man; equilibrium, or the horizontal dimension between human beings; free will; and, responsibility. ${ }^{16}$ On the basis of these four axioms Naqvi

\footnotetext{
14 Syed Nawab Haider Naqvi served during the late 1980s and early 1990s as director of the Pakistan Institute of Development Economics.

15 Naqvi 1994, XVII.

16 Naqvi 1981, 41-43, 47-56; Naqvi 1994, XVIII.
} 
has proposed that an Islamic economic system should rest firmly on four basis hypotheses: ${ }^{17}$

1. Economic activity is indissolubly linked with man's ethical environment (unity axiom);

2. Economic policy must aim at a 'just' balance among basic production, consumption, and distribution relations (equilibrium axiom);

3. Individual economic freedom and state control should be 'suitably' combined to reflect the distinctive Islamic concept of human freedom ${ }^{18}$ (free will axiom);

4. A conscious policy of redistribution of income and wealth, as well as resource transfers among the various classes and groups of the society, must be applied when the existing pattern of distribution is not 'just' from the Islamic point of view ${ }^{19}$ (responsibility axiom).

One key argument of the advocates of Islamic economics (or rather Islamic economic ethics) has been that the aim of an 'Islamic system' must be on maximising 'total' welfare and not just 'marginal' welfare. The basic policy objectives to achieve this goal are considered to be four, namely social justice, universal education, economic growth and maximising employment generation. Islam is also normative for the choice of policy instruments to achieve the basic policy objectives. Thus, within an Islamic system, the policy instruments that are identified to achieve social justice have to deal with the institution of private property, the ownership of the means of production, growth-promoting policies and the social security system. As the key element of the whole system is the question of social justice, as well as the social security system, I will further return to on these questions below. ${ }^{20}$

Social justice forms the cornerstone of the Islamic economic system. The argument of the Islamic economists, such as Naqvi, is that social justice is based on the principle that all that exists in the Universe belongs to God, man being God's vice-regent on earth and holding the bounties of God only in trust. This

\footnotetext{
17 Naqvi, 1981, 62, slightly revised and extended in Naqvi 1994, 55.

18 According to Naqvi, individual freedom should be guaranteed but can be regulated by the state if it becomes inconsistent with social and collective welfare (Naqvi 1994, 55).

19 Naqvi's argument is that although Islam does accept individual freedom as an absolute value, Islam also puts limits on it when the exercise of personal freedom becomes obviously inconsistent with social well-being, thus conflicting with the responsibility axiom (Naqvi 1994, 55-56). In his earlier book, Naqvi highlighted the distinction between the rights of the individual agent and the needs and provisions required by the collective which he/she indisputably belongs to (Naqvi 1981,46).

20 On the other basic objectives and policy instruments, see further Naqvi 1981, 90-95, 98-103, 105-06 and Naqvi 1994, 88-107. In his latter work, Naqvi has enlarged the four objectives to five, including individual freedom, distributive justice, economic growth, universal education and maximum employment generation. His change of concepts, distributive instead of social justice, is due to a re-definition of his earlier argumentation. With regard to the policy instruments, however, there is no difference between the two texts.
} 
principle is the basic concept of Islam, namely the unity of God. Man is thus only a trustee, never an absolute owner. According to Islam, man has a duty to do justice and an obligation to give and share. Therefore, as every man is equal before God this also implies the equality of all men in relation to each other. Although man should receive what is due to him by virtue of his productive effort (free will axiom), those who cannot work due to various acceptable reasons should receive adequate income to cover their basic needs, irrespective of the level of their productive effort. ${ }^{21}$ However, equality is not an absolute norm according to contemporary Islamic economists, but a relative one. The basic welfare criterion is that if, and only if, a relatively equal distribution of income and wealth today would lead to lower future social welfare, then a more unequal distribution should be preferred. ${ }^{22}$

An elaborate social security system is perceived as an integral part of an Islamic economy. The Islamic economists agree in theory that the key idea is the transfer of resources from the rich to the poor. However, they disagree on the question of state intervention. According to Naqvi, the state must intervene to equalise the total utility of social consumption and to create a social balance, 23 whereas others, such as Umar Chapra, advocate a more limited degree of state intervention. ${ }^{24}$ Thus for Naqvi, the process of income equalisation, buttressed by state legislation, should continue until 'the poor become honourable members of the society' ${ }^{25}$

Islamic economists have argued that an Islamic social security system can, and should, only be financed through legal ways of taxation, in particular through zakat. However, it has become painfully evident that the original legal model of Islamic taxation has become difficult to apply in the postcolonial Muslim states. Although Siddiqi, who was among the first modern Islamic economists, still regarded zakat, the poor rate or obligatory alms, as the sole basis for financing an Islamic social security system, ${ }^{26}$ later writers are rather sceptical and emphasise other possible arrangements for taxation. ${ }^{27}$ Naqvi goes even further by arguing that additional taxation should be imposed if the zakät funds are not sufficient ${ }^{28}$ whereas the Iraqi scholar, Baqīr Șadr, argued that neither zakāt nor the Islamic insurance system are sufficient in

21 Namely those who cannot work due to sickness, old age or other handicaps.

22 Naqvi 1981, 86-90; Naqvi 1994, 89-91. In his earlier work, Naqvi even argued in favour of the use of violence to destroy unequal distribution systems and emphasised that the preference of Islam to avoid social upheavals comes into play only when socially just conditions have already been established' $(1981,88)$.

23 Naqvi 1981, 103.

24 Chapra 1992, 223-24.

25 Naqvi 1981, 104. Naqvi strengthens this argument in his later work by underlining that in all cases of entitlement failure, when economic agents are deprived of their means of livelihood, state action will be required to rectify the situation (Naqvi 1994, 104-05).

26 Siddiqi 1948, 8-9.

27 Mannan 1970, 289. See also Chapra 1992, 270-75. According to Chapra, zakāt can only give temporary assistance and is no substitute for a modern social insurance system.

28 Naqvi 1981, 104; Naqvi 1994, 105. 
themselves to ensure a just distribution of income and wealth. ${ }^{29}$ These statements could not have been made by the pre-modern Muslim scholars since they would have been regarded as more or less equal to apostasy, $b i d a^{3}$ or 'unlawful' innovations. ${ }^{30}$

\section{Islamic Economics as an Academic Subject}

Islamic economics during the 1990s has become an established subject at Usmanu Danfodiyo University in Sokoto (formerly Sokoto university). As such, the development of the study of Islamic economics in Sokoto reflects the rising demands for the Islamisation of society in Northern Nigeria, a process which started during the $1970 \mathrm{~s} .{ }^{31}$ This is shown by the fact that, prior to the establishment of Sokoto university in the extreme Northwest of Nigeria in 1975, only Abdullahi Bayero College (now Bayero University) in Kano had an Islamic Studies Department. ${ }^{32}$ When Sokoto university was established, the Faculty of Arts and Islamic Studies was to become one of the core faculties, but, as in Kano, it mainly concentrated upon the humanities, religious studies, literature and Arabic. The promotion of Islamic literature and learning was concentrated to the Centre for Islamic Studies. At this stage, however, the Department of Economics showed no interest in Islamic economics. ${ }^{33}$

Things changed in Sokoto during 1984 when the Department of Economics presented a new Undergraduate Syllabus. For the first time some courses in Islamic economics were incorporated into the syllabus although students could only take Islamic Economics as a minor subject. ${ }^{34}$ During 1990, the undergraduate syllabus was reviewed once again and the courses in

\footnotetext{
29 Wilson 1998, 53.

${ }^{30}$ However, Naqvi is correct in stressing the point that zakāt, according to some of the schools of law, does not have to be paid to the state but can be directly given to the poor, thus creating a situation where there would be insufficient funds for the public security system. See further Aghnides 1916 and al-Qardawi 1999.

31 Ibrahim 1991. The Muslim Students Society (MSS), which had already been founded in 1954, played a crucial role in the politicisation of Islam in Nigeria.

32 Abdullahi Bayero College had been founded as the School of Arabic Studies during 1960. Two years later the institution was renamed and integrated as the Faculty of Arabic and Islamic Studies into Ahmadu Bello University (ABU) in Zaria. The college was given university status during 1976 and renamed as Bayero University Kano (BUK). ABU was founded during 1960 in Kano as Ahmadu Bello College, but was moved during 1962 to Zaria when it was given university status. Today, there are departments for Islamic studies at the universities in Zaria, Kano, Sokoto, Maiduguri and Ibadan (Reichmuth 1993, 191, 198; Zahradeen 1986).

33 Gusau and Abdullahi 1995, 34-35.

34 Despite the effort of lifting up Islamic economics as an academic subject, at that time it still suffered from a lack of teaching material, not to speak of more specialised literature. This, however, is not surprising as the main bulk of theoretical literature on Islamic Economics has been produced during the 1980s and 1990s. Taken together, a student in economics at Sokoto university could take a total of 12 units in Islamic economics out of a total minimum of 63 units. Heavy emphasis has been laid on the studies of $z a k \bar{a} t$, the obligatory alms or the poor tax, as it was regarded by the Islamic economists as one of the key objectives within Islamic economics (Gusau and Abdullahi 1995, 37-38).
} 
Islamic economics were enlarged. Since Islamic economics continued to be a minor subject, the majority of the courses were on "ordinary" economics. ${ }^{35}$ Courses in Islamic economics have put a rather strong emphasis on theory, which is not surprising since there has never been a 'pure' Islamic economy, not to mention a modern equivalent of what a past Islamic economy might have been. ${ }^{36}$ Also, there is a somewhat heavy concentration on zakāt and the Islamic concept of welfare, which can be understood as a kind of academic criticism of the lack of state responsibility towards its citizens in contemporary Nigeria. A curious phenomenon is the emphasis which the syllabus places upon the Sokoto Caliphate and its three most important scholars, namely Shehu Usman dan Fodio, Abdullahi dan Fodio and Muhammad Bello. There seems to be a clear need to perceive the Sokoto Caliphate - together with the era of the Prophet and the Khalifa ar-Rashidūn-as the 'golden' era of the Islamic state as well as the existence of an Islamic economy, as will be pointed out below.

However, despite the efforts of the Department of Economics and its teaching staff, Islamic economics still has a long way to go before it will achieve recognition among the academics as well as the students in Nigeria. Gusau and Abdullahi have given six reasons for why Islamic Economics has not been recognised as a major subject and have pointed out the major problems of the subject. First, there is opposition among "secular" and especially young Muslim and Christian teachers at Usmanu Danfodiyo University towards an Islamisation of knowledge; second, Islamic Economics is not regarded by the National Universities Commission (NUC) of Nigeria as a scientific subject; third, students are sceptical about their possibilities of finding a job if they were to hold a degree in Islamic instead of mainstream Economics; fourth, as is usual in Nigeria, the lack of funds is a major problem and the department has not been able to devote large sums to research and publications in any kind of economics; fifth, and following from the above, is the shortage of teaching materials; lastly, is the lack of government backing for the process of Islamisation. ${ }^{37}$

Despite the above problems, the Department of Economics at Usmanu Danfodiyo University has become one of the major centres of research on Islamic Economics in Sub-Saharan Africa. It has close links with the Centre for Research in Islamic Economics, Jeddah, the Islamic University of Islamabad and the Islamic International University of Malaysia in Bandung. Apart from the establishment of networks between Sokoto and the centres for research on Islamic economics, the scholars in Sokoto have tried hard to produce articles

\footnotetext{
35 After the 1990 review, a student is able to take a maximum of 23 units in Islamic economics out of a total of 160 units. See Appendix I for an outline of the units in Islamic economics taught at the Department of Economics.

36 The reason for this is that one basic precondition for an Islamic economy is the existence of an Islamic state, and, according to Islamic economists, there has never existed such a state apart from the short era of the Prophet and the first two Caliphs Abu Bakr and Umar. See further Azīz 1992.

37 Gusau and Abdullahi 1995, 53-56.
} 
and studies on Islamic economics. One reason for their efforts is the lack of applied literature on Islamic economics for the Nigerian setting. In this paper, I will concentrate on two fields of writing, namely the question of social justice and welfare within an Islamic setting and, secondly, the symbolic value of the Sokoto Caliphate. The bulk of the papers are written by two scholars, Sule Ahmad Gusau and Ibrahim Sulaiman. Gusau has been a lecturer at the Department of Economics at Usmanu Danfodiyo University since 1981 and belongs to the core advocates of Islamic economics in Nigeria. Sulaiman has taught at the Centre of Islamic Studies at ABU and is a founding member of the Council of Ulama. ${ }^{38}$ Both Gusau and Sulaiman also belong to a branch of scholars who could be labelled as 'revivalist' with regard to their writings on the Sokoto Caliphate and its legacy.

\section{Individual and Collective Obligations}

Islamic ethics distinguishes between personal and collective obligations. An individual or personal obligation, termed fard ${ }^{c} a y n$, is an act that every Muslim must personally perform. It comprises duties such as the confession of faith (shahāda), the five daily prayers (șalāt), fasting during the month of Ramadan (saum), the pilgrimage (hajj) and the payment of poor dues (zakāt). Collective obligations, fard kifäyah, on the other hand, consist of duties incumbent upon the community as a whole. A fard kifāyah is an act which every person is under the obligation to perform, until a sufficient number of persons have performed it, the rest being then absolved from this obligation. These obligations are considered to be imperative, fard, and have been established by $\operatorname{shari~}^{c} a$ evidence and for which there is no room for doubt. Further, to help perform a fard is itself considered a fard. ${ }^{39}$

Fard cayn is regarded by Gusau as the basis of social welfare in Islam. Gusau refers to four conditions which establish the personal obligations that, if adequate, would make public intervention unnecessary. These conditions are the obligation to support the family; the obligation to support close relatives; the obligation to pay zakāt and the obligation to pay kaffāra (expiations, which are distributed to the poor at a funeral or as atonements for a sin) when an offence is committed or as a compulsory duty. ${ }^{40}$ Gusau derives his conclusions first and foremost from the Qur'ān and the sunna. Although he also refers to the discussion among the juridical opinions belonging to the four established

\footnotetext{
38 The Council of Ulama was founded by Muslim intellectuals in 1986. It has been involved in criticising both the military regime as well as those religious leaders who have co-operated and collaborated with the regime. See further Loimeier 1997, 291-95, 302-14. On the role of Ibrahim Sulaimen, in particular, see 311-12.

39 Aghnides 1916, 112. There is, however, a difference among the Muslim scholars in the definition of terminology, such as fard, 'imperative', and wajī $b$, 'obligatory'. Wajī $b$ is an act whose value has been established by shari ${ }^{c} a$ evidence about which there is doubt, such as the giving of alms for breaking the fast or zakāt al-fițr (Aghnides 1916, 205).

40 Gusau 1993b, 113.
} 
Muslim schools of law, Gusau does not connect himself to a specific opinion on the law.

Gusau considers that support by the husband for his family is the most important form of charity. Next to the support of the family comes the obligation to support near relatives. In both cases, Gusau refers extensively to the disputation among the jurists of whom to include within these categories. Overall, he gives a very patriarchal interpretation of the family with regard to the position of the husband and wife/wives. Thus, according to Gusau, women and children are considered as the 'weaker' members of the household who must be cared for by the 'stronger' member, namely the father or the husband. However, Gusau emphasises that the obligation of the husband/father should correspond to the man's means and/or social custom. Especially problematic is his interpretation of the question of the wife's maintenance (nafaqat), where it is unclear whether he considers the marriage as a contract between two independent economic entities (man and woman) or if the 'weaker sex', the woman, has an actual right to demand support of her husband. ${ }^{41}$

Together with the obligation to pay zakāt and raffara, in an ideal situation there should be no need for other obligations to ensure the social welfare of the community. However, Gusau notes that raffara, as well as the payment of the zakät al-fitr, do not provide a continuous source of revenue for the poorer members of the community. Thus, there is a need for collective obligations to ensure social welfare for the community as a whole. ${ }^{42}$

Gusau's use of the concepts of fard 'ayn and fard kifāyah could suggest a distinction between personal and public obligations and responsibilities. It is therefore interesting, but not surprising for a Muslim scholar, that he puts zakāt both into fard ' ${ }^{c}$ ayn and fard kifāyah. The payment of zakāt implies an individual personal obligation, whereas the distribution and, especially, the purposes of zakat are determined by and handled as collective or public obligations. Thus, both the person, as well as the state, is tied to the rules about $z a k \bar{a} t$, the person by the conditions of payment, the state by its expenditure. Also, Gusau rightly puts zakāt al-fitr into the category of personal duties with no reference to any public obligations. ${ }^{43}$

Gusau's interpretation of collective obligations rests on two concepts, namely voluntary charity (infaq) and state imposed charity. According to Gusau, charity is voluntary as far as an individual person is concerned, but for the community as a whole it is obligatory. Gusau relates voluntary charity to four concepts, which, taken together as a whole, determine the concept of fard kifāyah. These four concepts are the concept of the nature of man's life as a

41 Ibid., 114-18.

42 Ibid., 126.

43 Aghnides emphasises that the main difference between zakāt and zakāt al-fitr is that while both are morally obligatory, the latter does not come under state control and lies entirely with the person himself (Aghnides 1916, 207 footnote 3). However, this distinction has not been so clear in some of the writings of the Muslim jurists, including those in the Sokoto Caliphate. See Weiss 1998. 
test; ${ }^{44}$ the concept of trusteeship; the concept of vice-regency and that of brotherhood and solidarity. ${ }^{45}$ Together these four concepts enlarge the spectrum of fard cayn to include the obligation to support 'other poverty groups' not covered by fard 'ayn, such as neighbours, orphans and the nonbegging poor. However, Gusau confines himself to referring only to the obligation to give șadaqa, voluntary alms or to provide financial means for institutions such as waqf, religious endowments. ${ }^{46}$

Voluntary charity would be enough to secure welfare in an ideal society, but not in the real world. Since Islam provides a person with Free Will, he/she might decline to fulfil his or her obligations if he/she chooses to do so. Therefore, as Gusau as well as the majority of Muslim jurists have stated, if the 'rich' do not aid the 'poor', the state may intervene to enhance the right of the poor. Thus, for Gusau, the raison d'être of the state is the fulfilment of common needs of humanity to the society as a whole. The state, together with the 'rich', have the responsibility to provide for the social welfare of the 'people' from the revenues such as fay (public property), ghanima (booty), kharāj (land tax), and jizya (poll tax on non-Muslim subjects). Gusau concludes that the responsibility of the Public Treasury, bayt al-māl, is to take care of the poor and the needy, to pay their debts and to help them to obtain a marriage partner if they are too poor to acquire one for themselves. However, Gusau emphasises that the needs that are satisfied at any time depend on whether voluntary charity is not sufficient, or is not available or is 'going in the wrong direction', thus leaving it to the 'state' to determine when and how to provide help. ${ }^{47}$

Gusau recognises a basic problem of the ideal model of state responsibilities. Although the Muslim jurists have obliged the state and the rich to provide for the poor, there does not seem to be any provision for enforcing that right. Thus, Gusau assumes that the whole question of provisioning by the state depends on the magnanimity of the government. ${ }^{48}$ In fact, he leaves this whole question open, which considerably weakens his argument. Another question, which neither he nor any other of the Islamic economists or Muslim jurists have addressed, is the root causes of poverty. Gusau, as well as the bulk of Muslim scholars, take it for granted that poverty exists within a particular community, especially that of the umma, the community of believers. In fact, neither the concept of fard cayn nor that of fard kifāyah are conceived upon the assumption that the alleviation of poverty is the main purpose of action. This is why modern scholars of Islamic economics, such as Naqvi, have tried to

\footnotetext{
44 According to Islam, wealth is considered as a test of man so that Allah will see if it is used for the welfare of fellow human beings. Deriving from this notion comes the idea of 'purification' of wealth by the payment of zakāt. See Basher 1993.

45 The concepts of vice-regency as well as solidarity and brotherhood are derived from the concept of trusteeship. The general understanding is that the rich members of the community have an obligation to ensure the welfare for the unfortunate members of the society.

46 Gusau 1993b, 126-31.

47 Ibid., 131-36.

48 Ibid., 139.
} 
reopen the question of poverty and have proposed far-reaching social and economic changes in social structures. ${ }^{49}$ However, Gusau, is more 'traditional' in that he declines to address, or to elaborate upon issues, such as the need for land reform, which might deal with the root causes of poverty.

\section{Debating Social Justice and Welfare}

One of the key arguments among the advocates of Islamic economics is the need for an Islamic social security system. Such a system should guarantee a 'minimum livelihood', such as food, clothing, shelter, medical care, marriage allowances and education 'to every citizen of the state that is incapable of providing the same for himself'. ${ }^{50}$ There is, however, no consensus among the scholars about the role of the state. As mentioned in the previous section, Gusau, for example, does not agree with a general minimum responsibility of the state but regards state intervention merely as the 'last resort'. ${ }^{51}$ In Gusau's mind, there is a clear distinction between the community and the state and for him, as a Muslim scholar in Nigeria, the present state cannot become an Islamic state. Instead, the Muslim community within that state should be strengthened. Secondly, by referring to Ibn Taimiya and his rigorous definition of who would be entitled to receive help through an 'Islamic social security system', Gusau excludes the 'parasites of society', such as 'loafers', and / or those who have become bankrupt due to 'indulgence', 'extravagance' and 'illegalities' ${ }^{52}$ Clearly, Gusau's view is more of a political statement, criticising present conditions in Nigeria, than a theoretical elaboration of the Islamic social security system.

The objectives of an Islamic social security system, according to Gusau, are to enable the spiritual and social uplifting of the poor as well as the alleviation of poverty. While Gusau also stresses the provision of compensation for augmenting inadequate earnings without destroying incentives to earn, it is his stress upon poverty alleviation and the provision of an adequate standard of living which is my concern here.

Gusau makes a distinction between two types of poor people. First, there are those who are capable of productive potential but do not have the means to become productive. Second, there are those who are not capable of doing any work, due to physical handicaps, mental sickness or age. According to Gusau, the objective of poverty alleviation is concentrated on the first type of poverty, whereas the objective of providing adequate living standards covers the

\footnotetext{
49 Naqvi 1994, 99-103.

50 Gusau 1993a, 79.

51 Gusau 1993a: 78-80; see Wilson 1998 on the various positions about state intervention among Islamic economists. Gusau is of the opinion that government responsibility comes only after other 'arms of the society', such as family, relatives, neighbourhood or the community, have failed to provide help.

52 Gusau 1993a, 80; on the economic concepts of Ibn Taimiya, see Islahi 1988.
} 
second type ${ }^{53}$ In the case of the poverty alleviation, Gusau supports the view of unrestrained giving, 'sufficient to uproot poverty and put the recipient on his or her feet', without clarifying what would be 'sufficient'. He stresses that such a policy has to be tied to the question of disincentives and resource availability, again without giving the problem more significance. Instead, Gusau's main concern is about the various positions of the Muslim scholars on the principle of giving, especially the question of whether there should be any upper and lower limits on what may be given to a recipient. His own conclusion is that there should be no limits. ${ }^{54}$

The aim of a policy of unrestricted giving is partly to change the socioeconomic structures, although Gusau is rather vague on this question because his aim is to 'attack the base (of poverty) by offering the victim [a] job to do or by aiding him with sufficient necessary capital'. ${ }^{5}$ Gusau touches on one key problem, namely that neither the Qur'ān nor the sunna are very clear about the question of the distribution of obligatory alms (zakat). Although recipients are identified as, among others, 'the poor and the needy', it is by no means clear who they are and what they should receive. Some jurists, such as alGhazālì, have tried to give a thorough account of the various cases of poverty and need and what each recipient could receive ${ }^{56}$ but Gusau does not take this question any further.

The same need for clarification also arises out of Gusau's aim for the provision of an adequate living standard. Gusau emphasises that the state is obligated to provide an adequate standard of living whenever the need arises in the absence of other avenues of support. Further, the provisions should be adequate to satisfy needs. However, Gusau does not provide any explanation of what he considers as 'adequate', and his statement that his notion of 'adequate' is tantamount to that of 'enough' in the hadith, from which he has quoted, does not provide an effective analytical tool. On the other hand, it seems as if Gusau has some kind of distinction in mind when he distinguishes between a 'minimum guarantee', which is not 'enough', and 'adequate guarantee' which might seem to be 'enough'. ${ }^{57}$

Apart from the idea of alleviating poverty and providing an adequate standard of living, the provision of help in the cases of temporary or permanent contingencies is perceived as an obligation. ${ }^{58}$ The obligation of provision

53 Gusau 1993a, 84.

54 Ibid., $84-89$.

55 Ibid., 84.

56 Al-Ghazālī 1966, 53-60.

57 Gusau 1993a, 90. On the concept of 'minimum basic needs', Gusau quotes al-Ghazālì. According to al-Ghazālī, minimum basic needs include food, shelter, medical care, education and such other goods and services considered necessary according to social customs (Gusau 1993a, 93).

58 Gusau includes, under 'temporary contingencies', unemployment, widowhood, sickness, maternity and child birth, pursuit of studies and travelling. 'Permanent contingencies' include blindness, severe mental illness, serious and persistent illness and decrepitude. 
derives from fard kifāyah, but Gusau locates it within the sphere of the Islamic social security system and, thus, the state.

However, if an Islamic social security system were to be set up in practice, it would soon face serious problems. First, the unclear definitions of concepts and categories make the system vulnerable to abuse. Secondly, there would be dangers of bureaucratisation and fraud. Again, as Gusau is clearly addressing the malfunctioning and non-existent public welfare system of Nigeria, he is not in favour of a total implementation of a public Islamic social security system. Thus, instead of advocating the idea of a 'strong' state, he stresses a 'minimal' state interference. For one thing, he argues, there should be as little incentive as possible for somebody to seek resources from a social security system. In this case, Gusau follows a rather restrictive course of argumentation, based mainly on the Qur’ān and the sunna. First, work should be encouraged and begging should be discouraged. In fact, Gusau defines work as a fard kifäyah, as it is performed for the survival of the community. Begging, on the other hand, is severely condemned, except "for those genuinely in need of it" ${ }^{59}$ Further, mere unemployment is not, according to Gusau, a sufficient ground for a share of social security benefit. The unemployed person has to prove that he/she is impoverished by this condition, that he/she does not have an alternative income and that his/her unemployment does not arise from complacency. ${ }^{60}$

\section{Zakāt as articulated in Sokoto}

As has become evident from the two articles by Gusau which have been extensively presented in the previous two sections, zakāt forms the cornerstone of any Islamic social welfare system. The material basis for such a system, be it run by the state or the community, would be realised through the zakat. Thus, the very question of whether such a system would, or could, function is based on the concept of zakat -who pays, how much, who distributes it and to whom. Zakât, as a concept, is both a challenge and a source of conflicting arguments, because it is both a religious duty as well as a social tax. In fact, no other fiscalcum-religious concept has been analysed more extensively and intensively by Muslim scholars than zakāt. However, some Islamic economists, such as Arif, stress that it would be naive to think that zakāt would be sufficient to run an economy and he rejects the idea that zakat could be the basis of the fiscal system of a modern Islamic economy. ${ }^{61}$ Others would argue that zakat is some kind of

\footnotetext{
59 However, here again, the sunna is rather unclear in which situation one is allowed to beg, as the Prophet is quoted to have said 'in a situation which makes it necessary', although he also has tried to define such a situation as when 'a person who is in grinding poverty, one who is in serious debt, or one who is responsible for blood wit and finds it difficult to pay' (Gusau 1993a, 104). In fact, this would give ample of loopholes for a beggar to find excuses to beg.

60 Gusau 1993a, 104-05.

61 Arif 1993, 12. He even goes further and complains that there has been too much emphasise on zakāt in the literature and argues for the device of a modern Islamic tax system, but such a
} 
'Sampo', ${ }^{62}$ namely that the implementation of zakāt in an Islamic economy would create all the good things that would be desirable from an Islamic standpoint.

There is little doubt that Gusau and his co-writer Bawa belong to the advocates of the Sampo-model. According to these authors, the implementation of zakāt would generate both economic and spiritual development. Gusau and Bawa stress the point that no exogenous considerations, economic or political, and no fiscal contingency, except that related to zakatt, would be allowed by Islamic economic authorities to curtail the social welfare expenditure below the quantity raised through zakāt. ${ }^{63}$ Zakāt would improve human resources since it could be used to build schools, as well as to provide health and medical care. Further:

It may also be used to finance researches in agriculture, industry and technology; to provide scholarships for scholars in professions like engineering, finance, medicine, which are very important for development. [Also] for the campaign of public enlightenment against frauds, dishonesty, cheating and other kinds of evils [as well as] for providing weaponry and other defence equipment, for the training of soldiers, for researchers in weaponry, military hardware etc. All these help development. 64

Apart from the improvement of human resources, zakāt is expected to generate the expansion of useful production as well as the improvement of the quality of life by creating employment and social security. Another goal is to achieve a balanced development through the redistribution of wealth and the local disbursement of zakāt funds. Gusau and Bawa also expect that the implementation of zakāt would reduce Muslim countries from being dependent upon development aid from non-Muslim countries while creating more integration among Muslim countries. They are also convinced that zakāt would encourage a growth of national income by encouraging people with idle assets to put them into productive investment and to encourage people to work. Last but not least, zakāt would enable the means to be assembled for poverty alleviation. ${ }^{65}$

However, the main aim of zakāt should be the spiritual uplifting and, especially, the spiritual development of Muslims. Gusau and Bawa present a religious-legal argument in favour of zakāt, stressing the combined effect of its character as worship and the purification of the wealth and mind:

The virtues created by charity, both in the rich and the poor, lead to spiritual upliftment. The spending itself takes away the soul from the love of material into the love of God and into earnest preparation for the hereafter, while the reverse takes

system could be only implemented after a thorough discussion on the Islamic criteria for such taxes.

62 Sampo is a mysterious object often referred to in the mythological songs of the Finns. It has the potency to provide various forms of prosperity. Usually it is portrayed as a magic mill or money spinner.

63 Gusau and Bawa 1995, 114.

64 Ibid., 112

65 Ibid., 114-19. 
away from the love of God and the preparation for the hereafter. Generosity leads to paradise while miserliness leads to hell fire. 66

Next, Gusau and Bawa identify eight problems that could arise due to the implementation of zakāt if it 'is not handled well'. First, there is a possible negative influence on work as people might refuse to work and take zakāt instead. However, Gusau and Bawa stress that this is unlikely to happen due to the strict rules of the disbursement of zakat, but they also account for the major role that the state can play in controlling the system. Second, zakāt may encourage some people to retire early, but here again the state should set up a minimum retirement law to prevent this possibility. Third, zakāt may cause labour supply to fall, but Gusau and Bawa do not consider this to be likely. Fourth, a generous zakāt system may cause people to lose their zeal for learning and become lazy, but Gusau and Bawa believe that the opposite would actually be the case. Fifth, zakāt could reduce earning, and sixth, zakāt may depress investment through lower savings, but, again, Gusau and Bawa do not believe this to be likely. Seventh, a generous zakat system may encourage the poor to have more children and aggravate the population problem but, according to Gusau and Bawa, the increase of population should not be understood as a problem but as the actual goal of Islam. Last, a generous zakāt system would make family members independent, which could make women feel less compelled to live with their husbands. However, Gusau and Bawa are convinced that the Islamic custom of marriage prevents such a 'horrifying' development. ${ }^{67}$

\section{The Ideal of an Islamic Government}

Much of Gusau's and others' writings on Islamic economics in Nigeria has two aspects. On one hand, the advocates of Islamic economics are trying to develop a holistic approach to the present economic and political problems of Nigeria. ${ }^{68}$ This holistic approach puts emphasis on moral and ethical values which ought to dominate economic and political policies. Religion is primary and, due to the Islamic approach, Islamic law and the norms of Islam cannot be overruled. Contrary to the impression conveyed above, therefore, Gusau and others in Nigeria are imagining the possibilities of an Islamic economy as much as making political statements on present conditions in Nigeria.

On the other hand, the holistic approach of the Nigerian Islamic economists is also an attempt to identify a situation when a past Islamic state had lived up to the ideal model that is presented by contemporary Islamic economists. The general concept in the Muslim world is that the Prophet had established this ideal model in Medina when he combined his rule over the

\footnotetext{
66 Gusau and Bawa 1995, 117.

67 Ibid., 119-21.

68 Gusau 1995.
} 
community of the believers with that of the city of Medina. The general argument is that this religious-political state community was living up to the ideal of a just society ${ }^{69}$ For twentieth century Islamic economists, as for previous Muslim writers, the actual existence of the ideal community in history is seen as the best and only proof for the superiority of their approach. In fact, many of the arguments of the Nigerian Islamic economists conform very closely to the idea of a past existing reality. However, the growth of Islamic studies in Northern Nigeria has brought up another ideal state which could, and should, serve as a model for contemporary Nigeria. This ideal state is the Sokoto Caliphate.

Contrary to the Western academic picture of the Sokoto Caliphate, the use of the Caliphate among the Nigerian advocates of Islamic economics is based on the ideological legacy of it. ${ }^{70}$ The various attempts by Muslim Nigerian scholars to idealise the Caliphate must therefore be understood as part of their apologetic discussion about the ideal state in the real world and not as historical research on the political or fiscal economy of the Caliphate. The idealistic perspective that equates the Sokoto Caliphate with an Islamic state is made obvious because the Muslim Nigerian texts present the theoretical outlines of the principles of the political rule and fiscal administration of the 'founding fathers' of the Caliphate, Usman dan Fodio, his brother Abdullahi dan Fodio and his son Muhammad Bello, the first Caliph. ${ }^{71}$ What is lacking are investigations on how the teachings of the 'founding fathers' were implemented and followed. In other words, if the Sokoto Caliphate was ruled according to the principles of Islamic economy, how did it function in practice?

The investigations of, for instance, Sulaiman and Gusau on the Sokoto Caliphate should not be presumed to be historical studies on the implementation of Islamic economics but rather as political statements about what constitutes the ideal Islamic state in a Nigerian setting. ${ }^{72}$

\footnotetext{
69 Siddiqi 1948, V-VII; Mannan 1970, 283.

70 The historiography of the Sokoto Caliphate is complex. The basic arguments are not contested, such as that the Sokoto Caliphate was established as the outcome of a victorious militant Islamic reform movement during the early nineteenth century and that the aim of the key figures of the movement was to establish an Islamic state (Last 1967; Hiskett 1973). However, there is little agreement about the impact of the Caliphate. For those who benefited from the relative political stability and economic growth during the nineteenth century, the Caliphate was the golden age. But for those who were on the margins or outside of this development, the Caliphate could never be the perfect society. Thus, twentieth century Western and Westerninfluenced academic research paints a rather conflicting picture about the Sokoto Caliphate (Last 1989; Weiss 1997). However, this is not surprising since the aim of academic research has been the historical development and actual impact of the Caliphate. For a critical discussion on Nigerian academic historiography, see Kaese 1999.

71 See, for example, Kani and Gandi (eds) 1990 as well as Malami and Sabir 1993.

72 See, for example, Sulaiman 1986.
} 
In our time of materialism, injustice, inequality, irreligiousness and other evil, it would be very useful to emulate the Sokoto Caliphate leaders with respect to their policies, of course with some modifications, to suit contemporary needs. ${ }^{73}$

Thus, Sulaiman, in one of his monographs, sets out a theory of government and gives the outlines of a public welfare system. Although his argument is based on the most influential theoretical treatises of Usman dan Fodio, Abdullahi dan Fodio and Muhammad Bello on the principles of a Muslim government and how to rule an Islamic state, Sulaiman provides an account of the responsibilities and obligations of a modern Islamic government. Sulaiman argues that the purpose of government responsibility is to preserve public morality, through the regulation of markets and the promotion of social justice in society. Though using the treatises of the above-mentioned three 'founding fathers', Sulaiman accuses the then secular-military Nigerian government of Babangida of moral bankruptcy, because it does not safeguard the spiritual values of Islam, ensuring that proper standards of hygiene are maintained in homes, that health hazards are avoided, that public health facilities are maintained and that streets are kept clean and free of waste. ${ }^{74}$

In Sulaiman's text, the ultimate purpose of the state is to ensure that the overall welfare of the Muslim umma is promoted and fulfils 'the objective of safeguarding the umma from social degradation, deprivation and injustice, and providing its individual members with the necessary means and opportunities to live honourably'. ${ }^{75}$ Again, the objective of Sulaiman is to reactivate the theoretical considerations, rather than the actual conditions of the Caliphate. Thus, his treatment of the principles of taxation in the Sokoto Caliphate is analogous to the late twentieth century debate among Islamic economists about the normative fiscal basis of the Islamic state. Sulaiman considers that taxes outside the original Islamic categories are illegal and unjust. In fact, Sulaiman even stretches his argument to conclude that:

A citizen pays only one form of tax at a time; if he is in a legal position to pay two kinds of taxes, then one lapses automatically. For example, a person does not pay zakat and kharaj at the same time even if he lives on land subject to kharaj. 66

Sulaiman's view places him among the group of Muslim scholars who regard any of the fiscal innovations of the Muslim jurists during the Umayyad and Abbasid period as belonging to the non-Islamic world.

Sulaiman's readings of Muhammad Bello's theories about how to frame policies to achieve socio-economic development also resemble those of the late twentieth century Islamic economists. A statement such as "Islam requires people to strike a balance between this world and the other and to do justice to them both" approximates, for example, to Naqvi's unity axiom, while "to be

\footnotetext{
73 Aliyu 1990, 188.

74 Sulaiman 1987, 48-49.

75 Ibid., 50.

76 Ibid., 55 .
} 
gainfully employed is an act of worship in its own right, and all occupations are accorded equal respect" is tantamount to Naqvi's equilibrium axiom. ${ }^{77}$ Sulaiman's attitude towards poverty and begging is similar to Gusau's insofar as Sulaiman states that "poverty is not a virtue, but rather an affliction with calamitous consequences" and "begging is even greater an affliction than poverty because the face of begging is one of utter humiliation". ${ }^{78}$

Sulaiman, like Gusau, considers that the individual has the primary responsibility to make him- or herself independent. The obligation of the state should be to help individuals to secure work from which they can adequately meet their basic needs. This minimal state intervention policy seems to derive from the writings of Muhammad Bello but, as has been pointed out earlier, the policy is part of contemporary Islamic economics. ${ }^{79}$

Gusau goes even further than Sulaiman in his identification of the Sokoto Caliphate as an Islamic economy. According to Gusau, there are nine central features that constitute an Islamic economy and all of them were to be found in the Sokoto Caliphate. ${ }^{80}$ However, Gusau and Sulaiman view both the characteristics of an Islamic economy in general, as well as the 'reality' of the Sokoto Caliphate in particular, as theoretical constructs. The writings of Usman dan Fodio, Abdullahi dan Fodio and Muhammad Bello consist of political and fiscal treatises about how government should be run and not accounts on how government and the economy actually developed within an Islamic state. Thus, although one can argue that the Sokoto Caliphate was an Islamic state, it is much more problematic to claim that an Islamic economy existed within this state.

\section{Conclusion}

Some Nigerian Muslim academics have called for the implementation of Islamic economics to Nigeria as the solution to Nigeria's present problems. The advocates of Islamic economics, such as Sule Ahmad Gusau and Ibraheem Sulaiman, are, however, rather unclear about the purposes of reform. It seems as if they are not so much concerned with identifying the root causes of social and economic problems in Nigeria as in concentrating their arguments around moral and ethical questions. Thus, their writings concentrate on the

\footnotetext{
77 Sulaiman 1987, 113.

78 Ibid., 113.

79 Ibid., 113.

80 Gusau 1990, 173-87. The nine features presented by Gusau are: 1 . The concept about the nature of the person's life being regarded as a test; 2 . Allah as the absolute owner of all wealth, the person being a mere trustee; 3 . The promotion of work and economic activity as a form of worship; 4. The Islamic state is based firmly on the concepts of brotherhood and solidarity of Muslims; 5 . The principle that the government is the protector of the weak; 6 . The collection of $z a k \bar{a} t$ from the rich and its disbursement to the poor; 7 . The definite economic responsibility of people towards themselves and those under them; 8 . The attachment to justice and equity; 9. The prohibition of extravagance.
} 
question of the ideal Islamic state and the ideal Islamic economy without working out, so far, a macro or micro model of how the economy of the ideal state could work in practice. What is also striking is the rather conservative tone in their writings, especially in Gusau's articles. Whereas some Islamic economists, for instance Naqvi and Mannan, have stressed the need for a modern implementation of Islamic norms, including the need for land reform and universal education, the Nigerian scholars seem to regard such reforms as undesirable. Thus, Gusau still puts emphasis on the seclusion of women. One wonders whether the call for an Islamisation of the state and the economy of Nigeria according to the 'Sokoto project' is to be doomed as an archaic solution. However, if the writings of the Nigerian Islamic economists are merely interpreted as critical remarks on morals and ethics, then the theoretical discussion about social justice and the obligations of the state are more interesting.

\section{Postscript}

Islamic economics and especially the question of an institutionalisation of zakāt has remained a hotly debated topic in Nigeria since the mid-1990s and especially during and after the implementation of $\operatorname{shari}^{c} a$ in most of the northern states at the beginning of the 21st century. ${ }^{81}$ Unsurprisingly, Christian and in general Southern voices have criticised the introduction of $\operatorname{shari}^{c} a$ in the North, whereas most Muslim authorities have backed the northern governments in their plans. Apart from implementing Islamic law in the states, the key argument of the propagators has been to strengthen the Islamic way of life in the North as well as to enable the "building of an Islamic ummah" in Nigeria. For many Muslim intellectuals, therefore, the implementation of the sharic $a$ is only the fist step towards this end. Along with the $\operatorname{shari}^{c} a$, the implementation of zakat as well as Islamic banking and finance is being discussed.

Much of the debate on the implementation of Islamic economics in northern Nigeria that has occurred during the last few years has a more or less direct link to the earlier, much more theoretical debate of the "Sokoto school". Among those scholars, who have taken an active role in today's debate is Sanusi Lamido Sanusi, who is Assistant General Manager at the United Bank for Africa in Lagos. ${ }^{82}$ Sanusi has delivered two interesting lectures on Islamic economics, one during 2000 at a seminar in Kaduna, entitled "Institutional Framework of Zakat: Dimension and Implications", 83 and another at a

81 See further my discussion in Chapter I. Twelve of the 19 northern states in Nigeria had by July 2001 introduced $\operatorname{sharī}^{c} a$ law, among others Zamfara, Kebbi, Kano, Jigawa, Borno, Sokoto, Niger, Bauchi, Gombe and Kaduna states.

82 Sanusi's homepage is located at http:/ / www.gamji.com/sanusi.

83 Sanusi 2000. Source: http: / / www.gamji.com/sanusi18.htm (printed 8.8.2001). 
seminar in Abuja in July 2001, entitled "Basic Needs and Redistributive Justice in Islam-The Panacea to Poverty in Nigeria". 84

In his first paper, Sanusi develops further some of the ideas of Gusau and other Islamic economists with regard to the implementation of zakat. Following the common argument of the Islamic economists, Sanusi argues that the collection of zakāt is a responsibility of the state, but as there exists no Islamic state in Northern Nigeria, the question is who should take the responsibility for zakât collection? According to Sanusi, there are two possibilities, one is that it is the responsible of the emirs to appoint the imams of the Friday mosques, and they are in turn responsible for the proper collection and administration of zakat. However, in those states where the government has adopted $\operatorname{shari}^{c} a$, the collection and administration of zakat becomes the responsibility of these (worldly) governments. Sanusi's argument is interesting as he clearly sidesteps the traditional role and position of the emirs in Northern Nigeria, turning some of today's northern Nigerian governments into de facto 'Islamic governments'. Sanusi draws a parallel between the present-day northern Nigerian governments and the Umayyad caliphate when claiming that zakāt should be supervised by the government. His reflection is interesting as the Umayyad period usually is regarded as one when worldly affairs took over the religious aspects of the Caliphate.

Even more interesting are his suggestions for providing new solutions to the handling of zakāt. Sanusi acknowledges the fact that Malìki law is the official code in northern Nigeria-and has been so since the pre-colonial era. However, according to Sanusi, some of the Malìkī interpretations on zakāt are no longer appropriate in modern Nigeria. First, whereas the Malīkì (as well as the Shafi ${ }^{\mathrm{i}}$ ) code limits the range of agricultural products on which zakat-as $u s h$-is obligatory (excluding perishables, vegetables, fruits and cash crops), the Hanāfi position claims that whatsoever crop that is grown for profit is zakatable. Sanusi points to the fact that non-zakatable crops according to the Malìkì code would become zakatable only if their sale forms part of zakatable earnings or the inventory at the end of the year, but then zakat would be 2.5 per cent of their value as opposed to 10 or 5 per cent for produce. Second, Sanusi is in favour of zakāt payment in cash-as the Hanāfi code allowsinstead of produce, livestock or trading goods. Interestingly, one could claim that Sanusi standpoint comes very close to British arguments at the beginning of the twentieth century, when British colonial officials argued for a tax reform in Northern Nigeria, which among others, included cash payment for the grain tithe (zakka). Third, Sanusi argues strongly for extending zakāt on corporate assets. ${ }^{85}$

Sanusi deals in his second paper with the question of 'redistributive justice'. One of his major arguments is that zakāt is an institutionalised vehicle for redistribution of income, thus situating himself among the mainstream of

84 Sanusi 2001. Source: http:/ / www.gamji.com/sanusi.htm (printed 8.8.2001).

85 Sanusi 2000. On the British policy concerning zakāt, see Weiss 1997. 
the Islamic economists. However, Sanusi's argumentation has a rather strong bias towards political economy, as he claims that

... the distribution of economic resources ... is the primary basis for dividing human society into socio-economic classes. When we consider in addition that ownership of economic resources both facilitates and is facilitated by control of state machinery and civil society, we find ourselves faced with the impossibility of discussing 'distributive justice' without reference to the class structure of our society. 86

Thus, instead of following the rather conservative position of Gusau and others, who generally do not spend much time in discussing the impact of political economy on their theoretical constructions, Sanusi is rather critical about simplistic economic and political solutions, especially when combined with Islamism:

Money has no religion; nor do hunger, unemployment and poverty ... any attempt to
speak of 'redistributive justice' in Islam must recongize its essentially populist character
$\ldots$ any process of Islamization that is not essentially aimed at the economic
empowerment of the popular masses falls short of the Islamic ideal in this area. 87

Whereas in 2000 Sanusi still was rather positive about the possibilities of the process of Islamisation in the North, among other things the change of governments from secular into 'Islamic' ones, one year later his critique of the Northern political leadership was direct and without any doubts. Whereas in the ideal setting the government and the state apparatus would be responsible for redistributing public wealth to ensure the elimination of poverty,

... in our society ... this principle has been completely subverted with public officers growing rich on the public treasury. For many of them, wealth is not a reflection of any kind of physical or intellectual endowment, it only reflects the will to steal. 88

However, for Sanusi the solution is not a return to or a revival of the glorious past—such as the Sokoto Caliphate or the uncompromising application of $\operatorname{shari~}^{c} a$ - but to acknowledge the political and economic structure of modern Nigeria, where "the poor farmer in Maiduguri has more in common with the poor farmer in Ogoniland than with his northern elite". 89

Sanusi's critical reflections and outlines about zakāt and Islamic economics in northern Nigeria highlight a different position than that of Gusau and earlier propagandists of Islamic economics in Nigeria. Whereas Gusau-and according to Sanusi most of the Nigerian Islamists-are conservative in their political and social argumentation, Sanusi represents another standpoint, namely that of a combination of Islamic economics and political economy. Still, as much of the debate so far has concentrated on about how to change society, the actual implementation of Islamic economics in northern Nigeria is yet to

\footnotetext{
86 Sanusi 2001.

87 Ibid.

88 Ibid.

89 Ibid.
} 
be realised. Yet, one could claim that views like that of Sanusi might provide a more realistic solution in the Nigerian setting than the one outlined by Gusau. In fact, Sanusi argues in favour of the unity of Nigeria and the survival of democracy as well as stresses the importance of education of the masses and, most important, the fundamental responsibility of the government to provide for the individual's basic needs-irrespective of his or her religious affiliation:

The people responsible for the Muslim northerner are no other than the northern Muslim elite. We must never let this elite forget that and we must remind our people that their true enemy is not the Nigerian constitution which guarantees their freedom and equality ... 90

\section{Bibliography}

Aghnides, Nicolas (1916) Mohammedan Theories of Finance, New York.

Ahmad, Khurshid (1980a). "Introduction", in Studies in Islamic Economics, Ahmad, Khurshid (ed.), Leicester \& Jeddah, xiii-xxiii.

- (1980b). "Economic Development in an Islamic Framework", in Studies in Islamic Economics, Ahmad, Khurshid (ed.), Leicester \& Jeddah, 171-88.

Ahmad, Ziauddin (1991). Islam, Poverty and Income Distribution, Leicester.

Aliyu, Ishaku (1990). "Aspects of Political Administation in Sokoto Caliphate with Reference to Diya al-Sultan of Abdullahi b. Fodiyo", in State and Society in the Sokoto Caliphate, Ahmad Mohammad Kani and Kabir Ahmed Gandi (eds), Sokoto, 63-74.

Arif, Mohammed (1993). "Islamisation of Economics", in Readings in Islamic Economics, Vol. 1., Sule Ahmad Gusau and Muhammad Lawal Ahmad Bashar (eds), Sokoto, 1-20.

Azizz, T.M. (1992). "An Islamic Perspective on Political Economy: The Views of Martyr Muhammad Bâqir al-Sadr", Al-Tawhîd, X:1, 139-54.

Ba-Yunnus, Ilyas (1980). "A Note on the Social Implication of Zakah in Modern Times", Some Aspects of the Economics of Zakah, in M. Raquibuz Zaman (ed.), Plainfield, Indiana, 179-83.

Basher, Suliman (1993). “On the Origins and Development of the Meaning of Zakāt in Early Islam", Arabica. Journal of Arabic and Islamic Studies, XL: 1, 84-113.

El-Battahani, Atta (1996a). “Economic Transformation and Political Islam in the Sudan: 19751989", Working Paper 5/96, Institute of Development Studies, Helsinki.

- (1996b). "The Social Impact of Economic Liberalization and Social Welfare in Sudan", Working Paper 6/96, Institute of Development Studies, Helsinki.

Chapra, M. Umer (1992). Islam and the Economic Challenge, Leicester.

Cowen, M. P. and Bob Shenton (1997). Doctrines of Development, London and New York.

Deegan, Heather (1996). Third Worlds. The Politics of the Middle East and Africa, London and New York.

Al-Ghazāì (1966). The Mysteries of Almsgiving, translated by Nabih Amin Faris, Beirut.

El-Ghonemy, M. Riad (1998). Affluence and Poverty in the Middle East, London.

Gusau, Sule Ahmad (1990). "Aspects of Islamic Economy in the Sokoto Caliphate", in State and Society in the Sokoto Caliphate, Ahmad Mohammad Kani and Kabir Ahmed Gandi (eds), Sokoto, 171-92.

- (1993a). "Objectives of an Islamic Social Security System", in Readings in Islamic Economics, Sule Ahmad Gusau and Muhammad Lawal Bashar (eds), Vol. 1, Sokoto, 77-112.

90 Ibid. 
- (1993b). "The Bases for Islamic Welfarism: A Look at the Concepts of Fard Ayn and Fard Kifaya", in Readings in Islamic Economics, Sule Ahmad Gusau and Muhammad Lawal Ahmad Bashar (eds), Vol. 1, Sokoto, 113-44.

- (1995). "The Roles Which Islamic Economics Can Play in Economic Development", in Readings in Islamic Economics, Sule Ahmad Gusau (ed), Vol. 3, Sokoto, 1-13.

- and Abubakar Abdullahi (1995). "Islamization of Economics in Nigeria", in Readings in Islamic Economics, Sule Ahmad Gusau (ed.), Vol. 3, Sokoto, 33-67.

- and Muhammad Aminu Bawa (1995). "The Role of Zakat in Economic Development in the Literature", in Readings in Islamic Economics, Sule Ahmad Gusau (ed.), Vol. 3, Sokoto, 109-23.

Hallencreutz Carl F. and David Westerlund (1998). "Introduction: Anti-Secularist Policies of Religion", in Questioning the Secular State. The Worldwide Resurgence of Religion in Politics, David Westerlund (ed.), third impression, London, 1-23.

Hiskett, Mervyn (1973). The Sword of Truth. The Life and Times of the Shehu Usumanu dan Fodio, Oxford.

Hodgkin, Elisabeth (1998). "Islamism and Islamic Research in Africa", in Islam et islamismes au sud du Sahara, Ousumane Kane et Jean-Louis Triaud (eds), Paris, 197-262.

Hunwick, John (1997). "Sub-Saharan Africa and the Wider World of Islam: Historical and Contemporary Perspectives", in African Islam and Islam in Africa. Encounters between Sufis and Islamists, David Westerlund and Eva Evers Rosander (eds), London, 28-54.

Ibrahim, Jibrin (1991). "Religion and Political Turbulence in Nigeria", Journal of Modern African Studies, 29: 1, 115-36.

Islahi, Abdul Azim (1988). Economic Concepts of Ibn Taimīyah, Leicester.

Kaese, Wolfgang (1999). “Akademische Geschichtsschreibung und Politik in Nigeria seit 1955: Ein Überblick", afrika spektrum, 34: 2, 237-64.

Kani, Ahmad Mohammad and Kabir Ahmed Gandi (eds) (1990). State and Society in the Sokoto Caliphate, Sokoto.

Last, Murray (1967). The Sokoto Caliphate, New York.

- (1989). "The Sokoto Caliphate and Borno", UNESCO General History of Africa, Vol. VI., Paris, 555-99.

Loimeier, Roman (1997). Islamic Reform and Political Change in Northern Nigeria, Evanston.

- (1998). "The Secular State and Islam in Senegal", in Questioning the Secular State. The Worldwide Resurgence of Religion in Politics, David Westerlund (ed.), third impression. London, 18397.

Malami, Hussaini Usman and Bayero Ahmad Sabir (1993). "Review of the Economy and Economic Policies of the Sakkwato Caliphate", in Readings in Islamic Economics, Sule Ahmad Gusau and Muhammad Lawal Ahmad Bashar (eds), Vol. 1, Sokoto, 169-86.

Mannan, M. A. (1970). Islamic Economics: Theory and Practice. A Comparative Study, Lahore.

- (1988). "The Economics of Poverty in Islam with Special Reference to Muslim Countries", in Distributive Justice and Need Fulfillment in an Islamic Economy, Munawar Iqbal (ed.), Islamabad and Leicester, 305-34.

Mason, Mike (1997). Development and Disorder. A History of the Third World since 1945, Toronto.

Naqvi, Syed Nawab Haider (1981). Ethics and Economics. An Islamic Synthesis, Leicester.

- (1994). Islam, Economics and Society, London and New York.

Osaghae, Eghosa E. (1998). Crippled Giant. Nigeria since Independence, London.

al-Qadawi, Yusuf (1999), Figh az-Zakāt. A Comparaive Study, London.

Qutb (Kotb), Sayed (1953). Social Justice in Islam, translated by John B. Hardie, Washington D.C.

Pfeifer, Karen (1997). “Is There an Islamic Economics?" in Political Islam. Essays from Middle East Report, Joel Beinin and Joe Stork (eds), Berkeley and Los Angeles, 154-65.

Reichmuth, Stefan (1993). "Islamische Bildung und ihr Verhältnis zum staatlichen Bildungswesen", in Muslime in Nigeria. Religion und Gesellschaft im politischen Wandel seit den 50er Jahren, Jamil M. Abun-Nasr (Hrsg.), Bayreuth, 165-200.

As-Ṣadr, Muhammad Bāqir (1983). Iqtisādunā. Our Economics. Discovery Attempt on Economic Doctrine in Islam, Teheran.

Saleh, Ismail Mudh and Rogayah Ngah (1980). “Distribution of Zakah Burden on Padi Producers in Malaysia", in Some Aspects of the Economics of Zakah, M. Raquibuz Zaman (ed.), Plainfield, Indiana, 80-153. 
Sanusi, Sanusi Lamido (2000). "Institutional Framework of Zakat: Dimension and Implications" being text of a lecture delivered at a symposium on Essentials for Building an Islamic Ummah held at Katuru Road Mosque, Ungwar Sarki, Kaduna on Saturday 2/12/2000. In http: / / www.gamji.com/sanusi18.htm.

- (2001) "Basic Needs and Redistributive Justice in Islam-The Panacea to Poverty in Nigeria", paper presented at the 2nd International Seminar on Islamic Banking \& Finance organized by Ahmed Zakari \& Co. (Chartered Accountants) at Abuja Sheraton Hotel \& Towers, 30th June \& 1st July 2001. In http:/ / www.gamji.com/ sanusi.htm.

Scott, James C. (1987). "Resistance without Protest and without Organization: Peasant Opposition to the Islamic Zakat and the Christian Tithe", Comparative Studies in Society and History, 29:3, 417-52.

Siddiqi, S. A. (1948). Public Finance in Islam, Lahore.

Steed, Christopher \& David Westerlund (1999). "Nigeria", in Islam outside the Arab World, David Westerlund and Ingvar Svanberg (eds), Richmond, 56-76.

Stenberg, Leif (1998). "The Revealed Word and the Struggle for Authority: Interpretation and Use of Islamic Terminology among Algerian Islamists", in Questioning the Secular State. The Worldwide Resurgence of Religion in Politics, David Westerlund (ed.), third impression. London, $140-66$

Sulaiman, Ibrahim (1986). A Revolution in History: The Jihad of Usman Danfodio, London and New York 1986.

- (1987). The Islamic State and the Challenge of History, London and New York.

Weiss, Holger (1997). Babban yunwa. Hunger und Gesellschaft in Nord-Nigeria und den Nachbarregionen in der frühen Kolonialzeit, Helsinki.

- (1998). "A Tentative Note on Islamic Welfare: Zakāt in Theory and Praxis in the Sokoto Caliphate", Hemispheres, 13, 63-77.

Westerlund, David (1982). From Socialism to Islam? Notes on Islam as a Political Factor in Contemporary Africa, Research Report 61, Uppsala.

- (1997). "Reaction and Action: Accounting for the Rise of Islamism", in African Islam and Islam in Africa. Encounters between Sufis and Islamists, David Westerlund and Eva Evers Rosander (eds), London, 308-34.

Wilson, Rodney (1998). “The Contribution of Muhammad Bâqir al-Sadr to Contemporary Islamic Thought", Journal of Islamic Studies, 9:1, 1998, 46-59.

Zahradeen, Mohammed Sani (1986). "The Bayero University Kano Has Come of Age", Kano Studies. New Series, 2:4, 17-24. 


\section{APPENDIX 1.}

Outline of the undergraduate courses in Islamic Economics at the Department of Economics, Usmanu Danfodiyo University, Sokoto (compiled from Gusau and Abdullahi 1995)

\section{Undergraduate I-level}

Introduction to Islamic Economic System (4 units)

- the tenets of Islamic system and the questions of what to produce, how to produce and for whom to produce

- the role of the public sector in an Islamic system

- introducing the discussion on zakāt, hisba, riba and Islamic banking

- questions of distribution, stability, welfare and development are touched upon

\section{Undergraduate II-level}

History of Economic Thought (2 units)

- one third of the course deals with Islamic economic thought, including contemporary developments of Islamic economic thought

- presents the roots of Islamic economic thought (Qur’ānic, Sunna) as well as individual contributions of Muslim scholars such as al-Ghazālì, Abu Yūsūf, Ibn Taimīya, Ibn Khaldūn, Usman dan Fodio, Abdullahi dan Fodio and Muhammad Bello

Economics of Production and Consumption in Islam (4 units)

- deals with advanced analysis of production and consumption relations, the focus being on need-oriented production and consumption

- discussion on production organisation, market structure and the role of the state

\section{Undergraduate III-level}

History of Economic Thought (2 units)

- one third of the course deals with Islamic economic thought

- the aim of the course is to consolidate the learning of UG-II course

Islamic Economic Analysis (3 units)

- structure and mechanisms of Islamic economic system as well as goals of the system

- Islamic conceptions of wealth, ownership and trusteeship

- zakāt and its operational implications for the economy

- fiscal policy in Islam and government borrowing as well as modes of financing the public sector

- the monetary system, banking without interest and central banking in an Islamic economy 
- Islamic guidelines for international economic relations and applicability of Islamic economics in a secular system and during transition

Economics of Zakāt (2 units)

- studies the socio-political, economic and spiritual dimensions of zakāt

- zakāt versus sadaqa and gift

- the role of zakāt in fiscal policy as well as zakāt administration and management

- additional sources of revenue to the government

\section{Undergraduate IV-level}

Advanced Islamic Economic Analysis (4 units)

- general equilibrium models of an Islamic economy, income determination, consumption and full employment models

- analysis of theories of money, price and interest in Islamic perspective

- theories of production and consumption under Islamic economy

- treatment of fiscal and monetary policies in Islam as well as economic policy and planning welfare in an Islamic state

- the applicability of Islamic economics in a secular system

Economics of Islamic Welfarism (2 units)

- discusses the concepts and the bases of welfare in Islam (Fard ${ }^{\mathrm{c}}$ Ayn and Farḍ Kifāyah)

- the role of the state in social welfare provision as well as the role of individuals and organisations

- discussion on zakāt

Economic Development Under Islamic Framework (2 units)

- Review of Islamic system with respect to its philosophy and objectives of the general scheme of Islamic life

- Islamic concepts of development and the philosophical foundations of Islamic approach to development

- goals of development policy and planning as well as balanced development and self-reliance 


\section{Contributors}

Franz Kogelmann, Ph.D., Researcher, German Institute for Middle East Studies, Hamburg, Germany

Roman Loimeier, Ph.D., Privatdozent, Department of Islamic Studies, University of Bayreuth, Germany; presently research on the development of Islamic education in Zanzibar

Sulemana Mumuni, M.Phil, Lecturer in Islamic Studies, Department for the Studies of Religions, University of Ghana, Legon, Ghana

Rüdiger Seesemann, Ph.D., Research Fellow in the Special Research Project "Local Agency in Africa in the Context of Global Influences", University of Bayreuth, Germany

Endre Stiansen, Dr. philos., Research Centre for Development and Environment, University of Oslo, Norway

Knut S. Vikør, Dr. philos., Director, Centre for Middle East and Islamic Studies, University of Bergen, Norway

Holger Weiss, Ph.D., Docent in African History, Lecturer in African Studies, Department of Asian and African Studies, University of Helsinki, Finland 